\title{
ASSESSING TREE HEALTH AND SPECIES IN THE GENTRIFYING NEIGHBOURHOOD OF THE JUNCTION TRIANGLE IN TORONTO, ONTARIO
}

\author{
By \\ Ritam Sen \\ Bachelor of Arts, Ryerson University, 2014 \\ A thesis \\ presented to Ryerson University \\ in partial fulfillment of the \\ requirements for the degree of \\ Master of Applied Science \\ in the Program of \\ Environmental Applied Science and Management
}

Toronto, Ontario, Canada, 2018

CRitam Sen, 2018 


\section{Author's Declaration}

I hereby declare that I am the sole author of this thesis. This is a true copy of the thesis, including any required final revision, as accepted by my examiners.

I authorize Ryerson University to lend this thesis to other institutions or individuals for the purpose of scholarly research.

I further authorize Ryerson University to reproduce this thesis by photocopying or by other means, in total or in part, at the request of other institutions or individuals for the purpose of scholarly research

I understand that my thesis may be made electronically available to the public. 


\title{
Assessing Tree Health and Species in the Gentrifying Neighbourhood of the Junction Triangle in Toronto, Ontario
}

\author{
Ritam Sen \\ Master of Applied Science, 2018 \\ Environmental Applied Science and Management \\ Ryerson University
}

\begin{abstract}
:
The purpose of this study is to examine the number, health, and species of trees in the gentrifying neighbourhood of the Junction Triangle. In this research, the tree inventory and questionnaire method were used. The questionnaire results show that respondents who moved in prior to 2007 view gentrification more negatively than residents who moved in after. The study found that there is a net growth of trees in the study area. Many invasive species have been removed, while more city recommended species have been planted. This research went on to find that trees in front of homes are in better condition than those planted on public land, and trees in front of improved homes are in better condition than those in front of unimproved homes. This is evidenced by the visible tree care and maintenance activities that are occurring on trees in front of housing but is absent from trees on public land.
\end{abstract}




\section{Acknowledgements:}

Over the last three years this thesis has been the primary focus in my life and ongoing source of stress, and happiness. I have never in my life worked so hard to achieve something as I have to complete this research. It has been a fulfilling journey and without the help of certain individuals in my life, I do not think this would have been possible.

First and foremost, I would like to thank my research supervisor Dr. Michal Bardecki, who has become somewhat of a guru to me. Without your advice and expertise, I would not have been able to complete this thesis, and if it were anybody else I do not think I would be where I am today. The time you have invested in me has helped shape me into a more mature human being, with a passion for science and knowledge. Dr. Bardecki, I am forever grateful for the chance to do this research under you.

I would also like to give a heartfelt thank you to my friends and family. To my parents, you have been an everlasting source of love and support throughout this research, especially during the times where I was so overwhelmed that I wanted to quit. Thank you for helping me stay strong in my times of weakness. To my dear friends, I am so grateful to have you all in my life. The constant love, support, kindness, and words of wisdom you have all shown me means the world to me. I know that I can count on each and every one of you when I need you. Thank you to Sandip, Sanjana, Hirad, Rudro, Chayla, Dolapo, Alex P., Alex S., Calvin, Aris, Nimesh, Nikou, Orson, Sharmilla, and Lisa.

Lastly, I would like to thank you to my dog, Shadow. I love you so much. R.I.P. 


\section{Table of Contents}

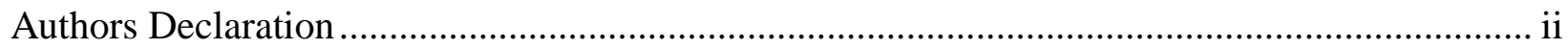

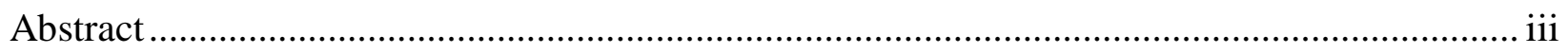

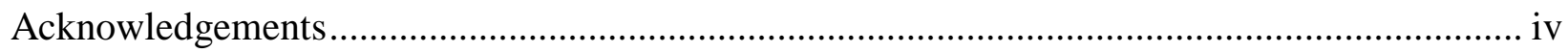

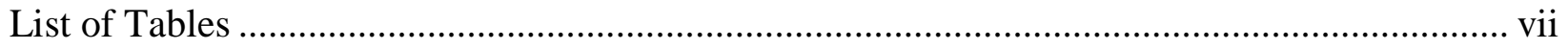

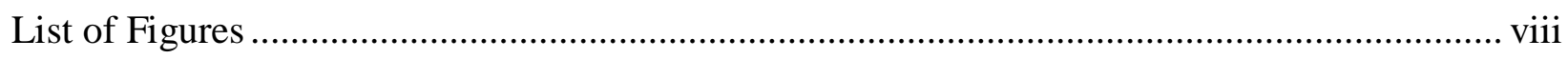

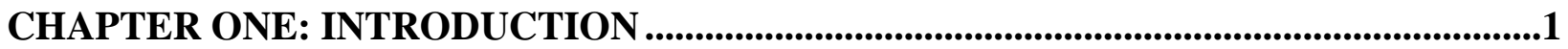

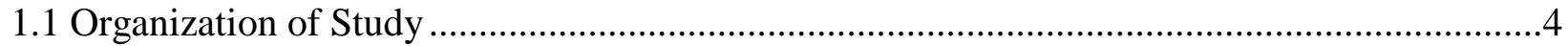

CHAPTER TWO: LITERATURE REVIEW ......................................................................................6

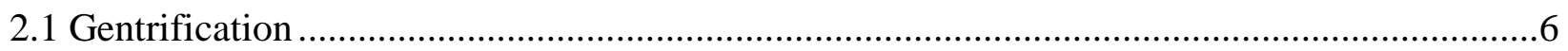

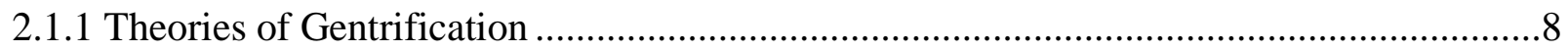

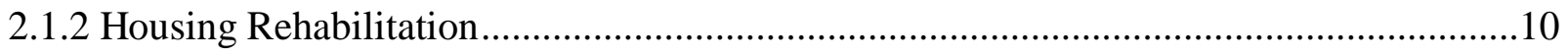

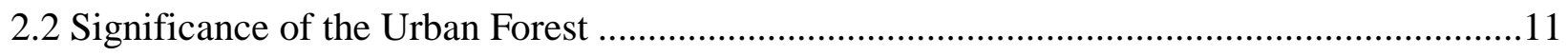

2.2.1 Environmental Benefits of the Urban Forest.........................................................12

2.2.2 Economic Impacts of the Urban Forest............................................................. 14

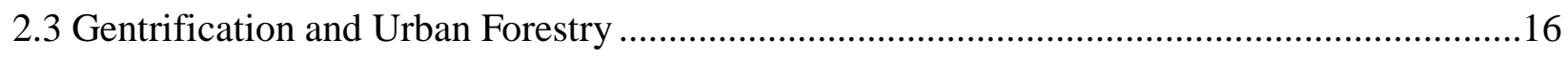

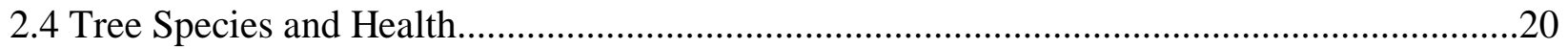

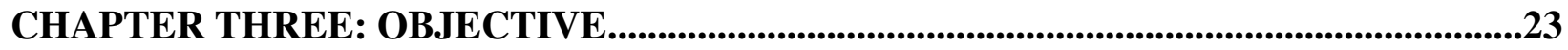

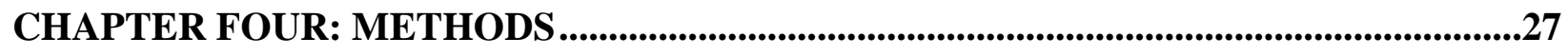

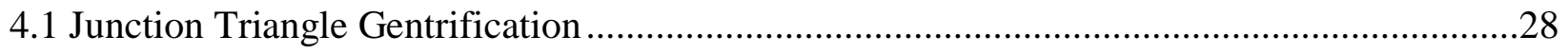

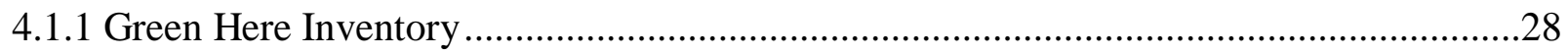

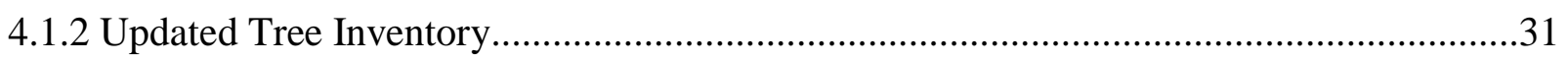

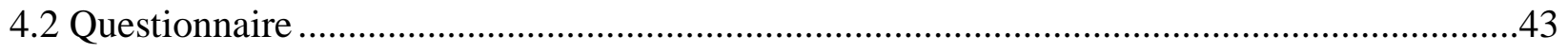

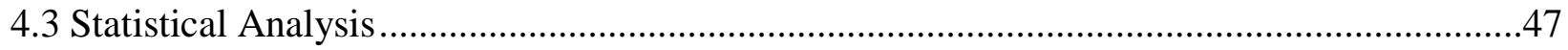

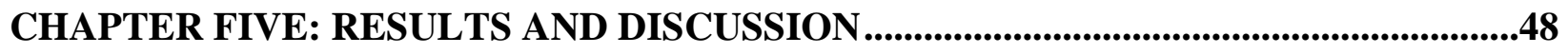

5.1 Evidence of Gentrification in the Junction Triangle ...................................................48

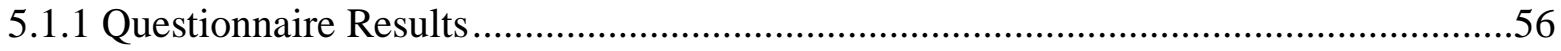

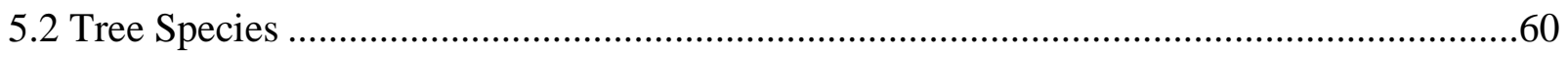

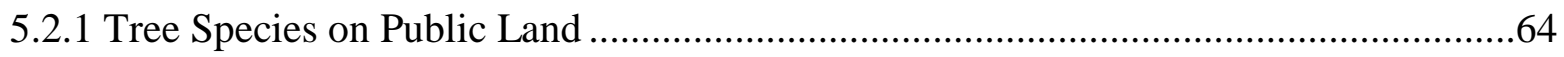

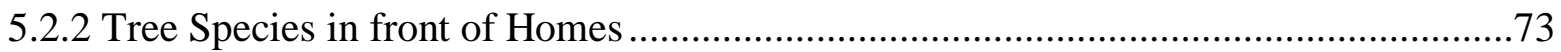

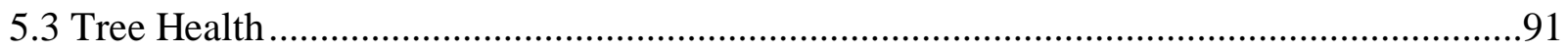


5.3.1 Tree Health on Public Land..........................................................................93

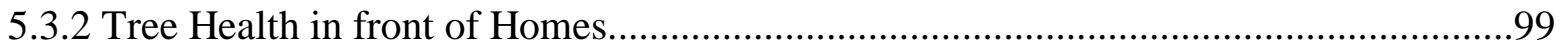

CHAPTER SIX: CONCLUSIONS AND RECOMMENDATIONS ......................................106

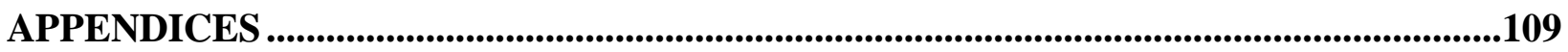

Appendix 1: 2016 Inventory of the Junction Triangle Study Area ....................................109

Appendix 2: Number and Species of Trees in 2007 and 2016 .........................................144

Appendix 3: Questionnaire, Introductory Materials, and Results ....................................... 146

Appendix 3.1: Questionnaire Recruitment Script .........................................................146

Appendix 3.2: Questionnaire Consent Form ............................................................. 147

Appendix 3.3: Tree and Gentrification Questionnaire ................................................150

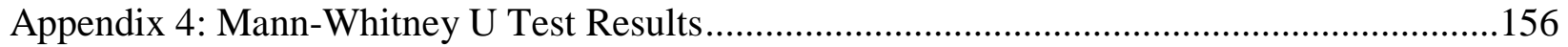

Appendix 4.1: Public Land Trees vs Trees In front of Homes ......................................156

Appendix 4.2: Boulevard Trees vs Park Trees ........................................................... 157

Appendix 4.3: Boulevard Trees vs West Toronto Railpath Trees....................................158

Appendix 4.4: Park Trees vs West Toronto Railpath Trees ............................................158

Appendix 4.5: Boulevard Trees Near Construction vs Not Near Construction ..................159

Appendix 4.6: Old Railpath vs New Railpath Trees ......................................................160

Appendix 4.7: Trees In front of Improved vs Unimproved Homes ................................160

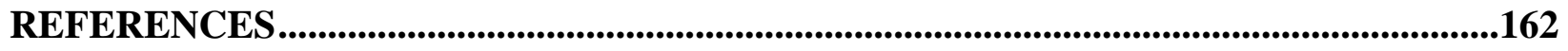




\section{List of Tables}

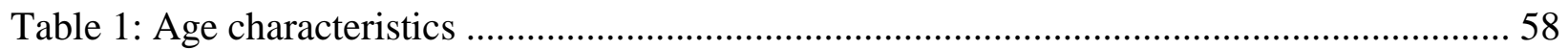

Table 2: Home ownership characteristics .......................................................................... 58

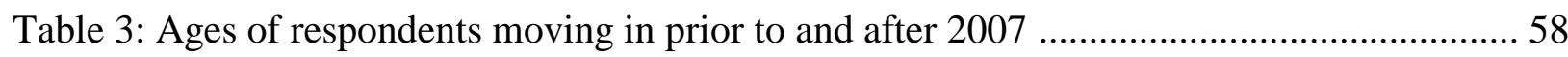

Table 4: Respondents who liked, disliked, or stayed neutral towards gentrification .................. 59

Table 5: Respondents who liked and disliked gentrification ..................................................... 59

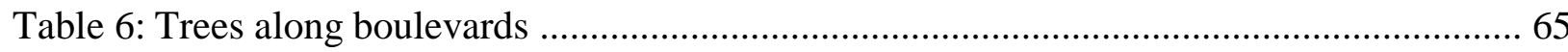

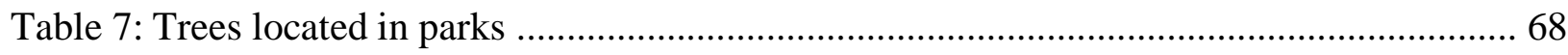

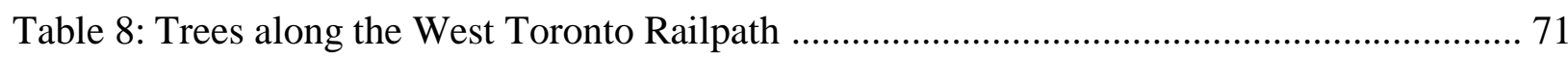

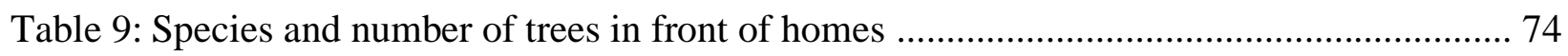

Table 10: Changes in species and number due to construction of stacked townhomes .............. 81

Table 11: Species and number of trees in front of improved homes ......................................... 84

Table 12: Species and number of trees in front of unimproved homes ..................................... 87

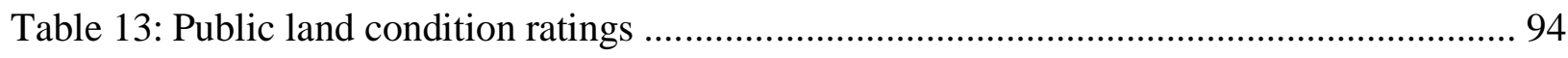

Table A1: The updated inventory conducted in 2016 ............................................................. 109

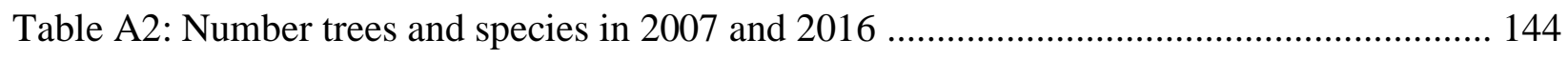

Table A3: Full results of the questionnaire ……………….................................................. 155

Table A4.1: Mann-Whitney $\mathrm{U}$ test between trees on public land and in front of housing ........ 156

Table A4.2: Mann-Whitney U test between trees on boulevards and in parks .......................... 157

Table A4.3: Mann-Whitney U test between boulevards and the West Toronto Railpath ......... 158

Table A4.4: Mann-Whitney U test between park trees and the West Toronto Railpath ............ 158

Table A4.5: Mann-Whitney U test between boulevard trees located near and not near

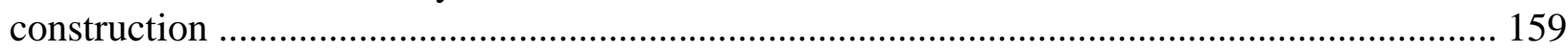

Table A4.6: Mann-Whitney U test between old and new Railpath trees ................................... 160

Table A4.7: Mann-Whitney U test between improved and unimproved homes ........................ 160 


\section{List of Figures}

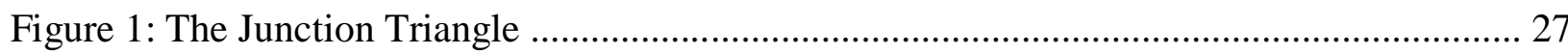

Figure 2: The Junction Triangle within the City of Toronto .................................................. 28

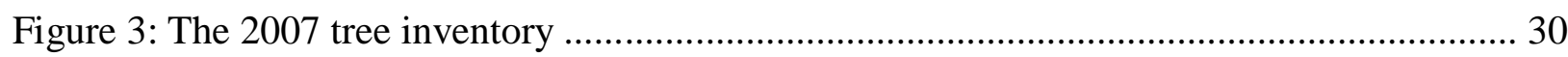

Figure 4: Improved homes in the Junction Triangle. These homes are two examples within the study area, and exhibit improvements such as reconstructed walls and windows, new paint, new fences and railings, improved stair cases, new trees and front garden, and new parking ........... 54

Figure 5: The construction of the Brownstones on Wallace in 2007 and 2009 ........................ 55

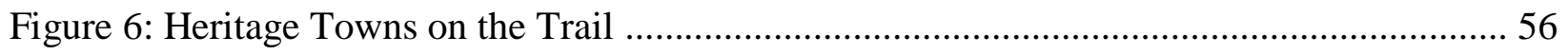

Figure 7: Updated map of the Junction Triangle study area. The blue dots on the map represent newly growing trees that were recorded during the 2016 inventory. The yellow dots represent trees that were cut down between the two inventory years, and the red dots represent trees were

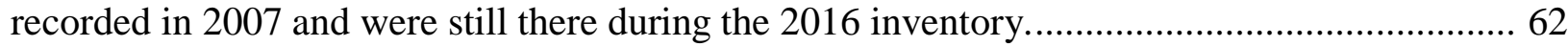

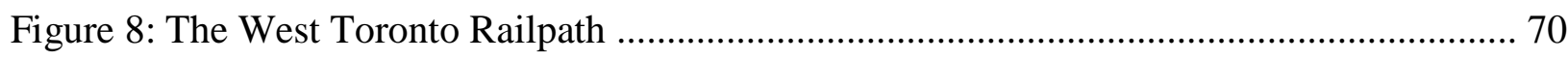

Figure 9: Park trees showing extensive damage ........................................................... 95 


\section{Chapter 1: Introduction}

The urban forest is a resource that is being increasingly recognized as an important and valuable natural land use, as it provides significant economic, environmental and social benefits for all citizens within a city. The urban forest is defined as a combination of native and exotic residential, street and park trees, and all associated vegetation in and around human settlements (Konijnendijk et al., 2006; Nowak et al., 2013; Miller et al., 2015). These trees serve as prominent features of the urban landscape and help to shape the cities in which citizens choose to reside. As these trees preform many critical services for residents, municipalities have a renewed interest in developing the urban forest (Merse et al., 2008; Wolch et al., 2014).

The City of Toronto is an example of a city that supports the management of a healthy and diverse urban forest. Currently, the urban forest of Toronto has approximately $26.6 \%$ tree canopy cover provided by an estimated 10.2 million trees (Nowak et al., 2013). It is estimated that Toronto's urban forest currently removes 1,905 metric tonnes of air pollution (e.g. $\mathrm{CO}_{2}, \mathrm{CO}$, $\mathrm{NO}_{\mathrm{x}}$ ) per year, with an associated value of $\$ 16.9$ million annually (Nowak et al., 2013). These trees are estimated to reduce residential energy costs by $\$ 9.7$ million per year (Nowak et al., 2013). There are at least 115 different tree species in the City of Toronto, and the top 10 most common species make up approximately $57.7 \%$ of all trees (Nowak et al., 2013). These trees include the eastern white cedar (15.6\%), sugar maple (10.2\%), Norway maple (6.5\%), white ash (5.3\%), Manitoba maple (5.0\%), green ash (3.6\%), white spruce (3.3\%), ironwood (3.2\%), Siberian elm (2.7\%) and European crab apple (2.3\%) (Nowak et al. 2013).

The City of Toronto has long recognized the importance of the urban forest resource and its associated benefits. Urban forests can strongly influence the biological environment and help 
mitigate many negative impacts of urban development (Dwyer et al., 1992). Urban trees have been shown to improve air and surface water quality which contributes to improvements in public health and well-being (Nowak et al, 1996; Nowak et al., 2010; Wolch et al., 2014). Air pollution is a major environmental concern in most major cities across the world, and an important focus of environmental research has been on the role of urban trees and vegetation in the degradation of air pollutants in cities (Nowak et al., 2006). Urban trees offer the ability to remove significant amounts of air pollutants, and consequently improve environmental quality and human health, primarily by the uptake of pollutants through the leaf stomata (Dwyer et al., 1992; Nowak et al., 2006; Manes et al. 2008). Trees can also influence the quality and flow of surface and ground water (Dwyer et al., 1992). Urban forests can play an important role in urban hydrologic processes by reducing the rate and volume of storm water run-off, and water quality problems (Dwyer et al., 1992). Storm water runoff, when not controlled, can be detrimental to water quality and human health, as water can absorb and hold many harmful pollutants (Perry, \& Vanderklein, 1996). Rainfall that falls onto impervious surfaces washes pollutants into water resources such as rivers, ponds, groundwater, and lakes (Perry, \& Vanderklein, 1996). As more pollutants accumulate in water resources, aquatic plant and animal life can suffer from disease, lack of dissolved oxygen, and nutrient imbalances. Trees reduce water runoff by intercepting precipitation, increasing rainwater infiltration into the open soil under the canopy, increasing water storage capacity of soils, and lessening pollutant wash off (Tyrväinen et al., 2005).

All of the benefits associated with the biological and physical environment have significant economic implications for the people who live in urban areas as well (Dwyer, 1992). The economic impacts of urban trees are an area that has been thoroughly studied, and research has concluded that trees have substantial impacts, such as energy conservation and increased 
property value. Trees play a vital role in energy conservation through a reduction in the cost of heating and cooling in homes and businesses (Dwyer et al., 1992; Wilson et al., 2013). In winter, trees can reduce the heating costs of homes and businesses by slowing and diverting cold winds from infiltrating into buildings (Laverne \& Lewis, 1996; Pandit \& Laband, 2010). During summer months, large trees can provide shade, resulting in a reduction in energy used for cooling buildings (Simpson \& McPherson, 1996). Along with energy savings, one of the most prominent economic benefits of trees is the relationship between forestry and property value. Property value is affected by trees as studies have shown a link between the presence of trees and an increase in sales value (Anderson \& Cordell, 1988; Merse et al., 2008; Escobedo et al., 2014). The presence of trees can make the urban environment a more pleasant place to live and work as there is a strong positive correlation between trees and quality of life in urban areas (Dwyer et al., 1992; Wilson et al., 2013). Environments with a presence of trees, are much more preferred than urban areas that lack vegetation (Schroeder, 1989).

For this reason, property owners may be interested in increasing the number and variety of trees in the surrounding area. In neighbourhoods that experience gentrification, one of the most important things for owners is to maintain property value. Gentrification is the process of rehabilitation of neighbourhoods that have experienced disinvestment and can be seen through the renewal of urban infrastructure and housing in poorer areas (Kaplan et al., 2009). As the quality and quantity of infrastructure and housing increases, middle class citizens tend to move into these neighbourhoods, while lower income citizens move away (Lees et al., 2008; Kaplan et al., 2009). In order to garner profit from resale, property owners must maintain the value of their land, which is possible through renovating and increasing the beauty of homes and buildings (Baum, 1993). In doing so, trees can be planted to add appeal and tranquillity to these renovated 
homes (Merse et al., 2008). However, the extent to which gentrification affects these trees is a topic that has not been studied thoroughly.

Trees are essential components of a city, and city governments, property developers, land-owners, and neighbourhood associations have invested large sums of money to maintaining the urban forest (Merse et al., 2008). These decisions to maintain the urban forest has been built upon numerous studies summing up the benefits that increasing the number of variety of trees can have for all residents of a city (e.g. Dwyer et al., 1992; Simpson \& McPherson, 1996; Merse et al., 2008). Along with the studies on urban forestry, there has been extensive research done on economic and social changes caused by gentrification (e.g. Ley, 1980; Caulfield, 1994;

Hackworth, \& Smith, 2001). However, there is a lack of extensive research done linking these two concepts together. There needs to be more research conducted on the environmental effects of gentrification, and by studying urban trees in a gentrifying neighbourhood, it is possible to gain some insight into this.

\section{1: Organization of the Study}

Chapter 2 consists of a discussion and review of the literature on both urban forestry and gentrification. This discussion focuses on the abundance of research on the environmental, economic and social aspects of both of these topics.

Chapter 3 states the purpose of this study, as well as the hypotheses that were tested. 
Chapter 4 outlines the specific methods that have been employed to test the hypotheses stated in the previous chapter. This section breaks down the methods in detail and gives reasoning as to why they are being used.

Chapter 5 consists of the results of the research, and a discussion of these findings. This section will present and summarize the data in both written and chart form, so they can be easily understood. A detailed analysis of the all the findings of this research will be presented.

Chapter 6 concludes the study and provides recommendations for future studies in the same field. 


\section{Chapter 2: Literature Review}

Chapter 2 consists of a review of the literature pertaining to both gentrification and urban forestry. Section 2.1 discusses a brief history of gentrification and what research has been done on the process, dating back to when the term was first coined in 1964. Three of the many theories that seek to describe gentrification have been detailed, and a common theme between them has been identified. This section moves on to further discuss residential gentrification through the processes of housing renovations. Section 2.2 discusses the significance of the urban forest, and its ecological and economic value. Section 2.3 links the concepts of gentrification and urban forestry together and discusses the relationship between them. Finally, section 2.4 identifies the importance of studying tree condition and species in the constantly changing urban environment.

\section{1: Gentrification}

Gentrification is an urban phenomenon where working class and lower income neighbourhoods of central cities experience reinvestment and are transformed into middle class residential and commercial areas (Lees et al., 2008; Gregory et al., 2009). The term was coined in 1964 by British sociologist Ruth Glass, who observed and wrote about the process in London, England (Saracino, 2010; Slater, 2010). Based on observational data, the changes she observed in London seemed to take the form of changing social structure and housing in the most populous areas of the city (Smith 1996; Saracino, 2010). Although this was the first instance of the term gentrification being used, Neil Smith (1996) has argued that gentrification may have happened earlier than when Ruth Glass had written about the phenomenon. Smith (1996) argues 
that the phenomenon may have occurred in the early $19^{\text {th }}$ century but was referred to as “embourgeoisement". Using historical works written by various sociologists, writers and scientists, such as Friedrich Engels, Marshall Berman, and Charles Baudelaire, Smith (1996) argued that there is an abundance of evidence suggesting gentrification took place in many cities throughout Europe, North America and Australia in the early $19^{\text {th }}$ century.

At its core, the process of gentrification is both a change in the demographic and socioeconomic aspects of a city as well as changes in physical structure. The process involves the movement of upper- and middle- income citizens into new or renovated properties in older, inner city neighbourhoods, formerly occupied by a lower income population (Lees et al., 2008;

Gregory et al., 2009; Kaplan et al., 2009). This lower income population usually consists of the elderly, the unemployed, welfare residents, working class individuals, and citizens near the poverty line who reside in poorer neighbourhoods because of cheap rent and convenient access to transit (Clay, 1979; Beauregard, 1986; Caulfield, 1994). Many lower income individuals tend to see gentrification negatively due to this improved quality in the neighbourhood, which results in higher rent, subsequently driving them out of the neighbourhood in search of more affordable living (Clay; 1979; Beauregard, 1986; Kaplan et al., 2009). As a neighbourhood gentrifies, it becomes more attractive for higher income citizens, who tend to view the process of gentrification more positively, due to amenities such as proximity to the downtown core, access to employment, transportation, recreation and entertainment (Beauregard, 1986; Kaplan et al., 2009). The citizens, often referred to as young urban professionals, tend to be young, wealthy, highly educated, and employed in professional fields (Beauregard, 1986; Caulfield, 1994). 


\subsection{1: Theories of Gentrification}

The urban pioneers and young urban professionals are the agents of the gentrification process, and thus provide the motivations and aspirations that shape it (Beauregard, 1986). These motivations are often described through theories and models which seek to explain and predict the process of gentrification and its future course in an orderly and sequential progression (Lees et al., 2008). One of the first models to be developed was created by professor and geographer Phillip Clay (1979). His model broke down gentrification into four different stages where he described the process as being driven by developers and citizens with artistic backgrounds, such as designers and architects, who saw the neighbourhood as a landscape to be improved (Clay, 1979; Lees et al., 2008). He described that in each stage of his model there were consistent increases in the involvement of these citizens, resulting in rapid transformations in the aesthetics and physical quality of the housing stock in the neighbourhood (Clay, 1979; Lees et al., 2008). One of the most important observations that he made was that as higher income individuals purchased property in the area, land and rent values increased, driving lower income citizens out and forcing them to resettle in other lower income areas (Lees et al., 2008).

Although Clay (1979) provides important explanations for neighbourhood renewal, his research is dated and is based on observational data from the beginnings of gentrification. A more modern theory, produced by geographers Neil Smith and Jason Hackworth, recognized that gentrification today is different from gentrification in the early 1970s (Lees et al., 2008). They developed a contemporary model of gentrification by observing its history in the United States (Lees et al., 2008). Their research argued that gentrification occurs in waves, where each wave is made up of several years and is separated by periods of recession (Hackworth, \& Smith, 2001). 
Their model recognized that recessions cause a downturn in property values, where developers, citizens, and investors take advantage of the housing market and begin to purchase housing stock in the inner city (Hackworth, \& Smith, 2001; Lees et al., 2008). During this time, these gentrifiers begin to redevelop housing in order to garner profit in post-recession periods when the housing market begins to revive, and wealthy citizens begin to purchase property (Hackworth, \& Smith, 2001).

Many theories of gentrification (e.g.: Ley, 1980; Rose, 1984; Caulfield, 1994) exist as researchers have different explanations of the process, how it functions, and what its causes are. These theories vary greatly in their analysis and present a variety of views of the process from many different educational backgrounds. Although these theories diverge, geographer Neil Smith has identified a component that seems to be the root from which all other theories stem. Smith identifies this component as the rent gap and uses the term to describe gentrification as being driven by differences in land values (Lees et al., 2008). The rent gap is a difference between the value of a plot of land given its current use, and the potential value that might be garnered under a better land use (Smith, 1987; Lees et al., 2008; Kaplan et al. 2009).

Deteriorated neighbourhoods tend to have housing with low structural value and, as a result, a low sales price (Lees et al., 2008). As both the sales price and structural value of buildings decrease, the potential value of the land can increase, and the difference between the land values, known as the rent gap, increases with it (Lees et al., 2008). When residents purchase housing with low structural value, they take advantage of the low sales prices and can begin to renovate the home. 


\subsection{2: Housing Rehabilitation}

Housing rehabilitation is one the most visible indications of gentrification (Helms, 2003). Renovations of inner-city housing forestalls its decay and improves the physical health of the city (Ley, 1986; Helms, 2003). Housing renovations can occur by altering existing structures or by a building new housing stock on empty plots of land (Ley 1986; Smith, 1987; Kaplan et al., 2009). Redevelopment of existing structures transpires through the remodelling of interior and exterior portions of a building, through improvements in bathrooms, kitchens, or gardens. Building new housing stock involves building newer, more luxurious homes on vacant plots of land, or razing older structures to make way for these new ones. Redevelopment and renovation can be a lengthy process as it requires residents to make fundamental decisions on home improvement projects.

Residents who seek to undergo renovations on their homes have a variety of reasons to do so, some of the more significant ones being a desire to increase sales value, repairing physical issues, as a form of self-expression, and upon recommendations from other residents (Wilson et al., 2013). Renovations as an expression of self or as a result from recommendations tend be pursued by those who see their home as a canvas or a project to be improved upon (Wilson et al., 2013). Repairing physical issues with a home has an impact on property value as a house that is deteriorating may not be valuable (Baum, 1993; Wyly, \& Hammel, 1999). The external and internal appearance of a building is important to maintaining property value, as dated designs can potentially depreciate the value of a home (Baum, 1993). Depreciation in property value is heavily related to design, obsolescence and quality, as buildings whose issues are not repaired can begin to physically deteriorate (Baum, 1993; Wyly, \& Hammel, 1999; Glaeser \& Gyourko, 2005). In gentrifying neighbourhoods, one of the top priorities is to maintain property value 
because residents who renovate housing desire to sell their home at a high price to garner profit from resale (Ley, 1986; Wyly, \& Hammel, 1999; Lees et al., 2008). Improving the physical quality and design of a building increasingly affects resale and rental values (Baum, 1993; Glaeser \& Gyourko, 2005; Lees et al., 2008).

Increasing the beauty of a home can entail planting trees and other associated vegetation as they improve the attractiveness of urban areas and increase property values as well (Anderson \& Cordell, 1988; Firehock, 2015). As more housing and housing types are introduced to inner cities, such as semi-detached and multi-family homes, there too are more opportunities for urban horticulture and arboriculture (Nowak, 1994; Johnston, 2015). These forms of housing allow for garden space, which is one of the main ways that trees entered the urban environment, as gardens, particularly gardens with mature trees, tend to add desirability to properties (Johnston, 2015).

\section{2: Significance of the Urban Forest}

Urban forestry is the combination of all native and exotic, street, residential and park trees within the city's boundaries (Konijnendijk et al., 2006; Nowak et al., 2013; Miller et al., 2015). Urban trees and greenery are increasingly recognized as a valuable resource, and their role in creating sustainable cities has been well researched (Chiesure, 2004; Nowak et al. 2010). Forestry is an essential component of community ecosystems, as the interaction between all elements of nature significantly affect the quality of urban life (Nowak et al., 2010). Essential services that trees can provide include reduced energy use, improved air and water quality, providing habitats for wildlife, and increased human health and well-being (Nowak et al., 2010). 
Active management and preservation of the forest is essential to expanding environmental, economic and community benefits to more citizens of the world's cities.

\subsection{1: Environmental Benefits of the Urban Forest}

The urban forest is a natural network that supports biodiversity, creates habitats, provides clean air and water, and promotes economic prosperity throughout the world's cities (Nowak et al., 2010; Nowak et al., 2013). Environmental research has increasingly confirmed the key service that urban trees play in improving the quality of the atmosphere around the world's cities (Dwyer et al., 1992; Nowak et al., 2006). Air pollutants, such as carbon monoxide, sulfur dioxide, nitrogen oxides, and volatile organic compounds, are of constant concern as they have negative effects on the quality of the air in our planet (Dwyer et al., 1992; Tyrväinen et al., 2005; Manes et al., 2008). The accumulation of particles in the atmosphere can potentially cause disease and damage to humans, plants and animals, as well add to the global phenomenon of climate change. Climate change is likely to add further to these air quality problems due to the fact that rising air temperatures and higher levels of solar radiation can lead to higher concentrations of ozone in the air, ocean acidification, crop damage and many other problems (Tyrväinen et al., 2005; Thompson et al., 2009; Nowak et al., 2010). Trees primarily aid in the reduction of air pollutants by the uptake of harmful chemicals through the leaf stomata (Dwyer et al., 1992; Nowak et al., 2006; Manes et al. 2008). However, some gases can be removed by the plant surface (Nowak et al., 2006). The concentrations of airborne chemicals are reduced as the leaves exchanges gases with the atmosphere, thereby capturing the harmful particles that can potentially be dangerous to life (Dwyer et al., 1992; Tyrväinen et al., 2005). Once inside the leaf, 
gases diffuse into intercellular spaces and may be absorbed by water films to form acids or react with inner-leaf surfaces (Nowak et al., 2006). Some particles can be absorbed into the tree, though most particles that are intercepted are retained on the plant surface (Nowak et al., 2006). The intercepted particle often is re-suspended to the atmosphere, washed off by rain, or dropped to the ground with leaf and twig fall (Nowak et al., 2006).

In addition to improving air quality, trees can influence the quality and flow of surface and ground water (Dwyer et al., 1992). Urban forests play an important role in urban hydrologic processes by reducing the rate and volume of storm water run-off, and water quality problems (Dwyer et al., 1992; Nowak et al., 2010). Trees reduce runoff by intercepting precipitation, increasing rainwater infiltration into the open soil under the canopy, increasing water storage capacity of soils, and lessening pollutant wash-off (Tyrväinen et al., 2005). By reducing run-off, trees function like retention structures that are essential to many communities by alleviating storm water management costs (Dwyer et al., 1992). If storm water run-off is not controlled, detrimental effects to water quality can be the result (Perry \& Vanderklein, 1996). Forests are key to clean water as rainfall onto impervious surfaces can absorb harmful pollutants and run off into surface water such as rivers, ponds and lakes (Perry \& Vanderklein, 1996). This creates water quality problems as pollutants from land integrate into surface water (Perry \& Vanderklein, 1996). As water quality decreases, many organisms, such as fish and aquatic plant life, can suffer from disease, lack of oxygen, nutrient imbalances and algal blooms.

Urban forests promote ecological stability not only through the improvements in air and water quality, but by providing habitats for wildlife and enhancing biodiversity (Dwyer et al., 1992). Increasing biodiversity of trees can improve forest resiliency as healthy and diverse forestry maximizes species richness, providing increased elasticity and strength when certain 
species are threatened (Thompson et al., 2009). The structural diversity of forests affects the wildlife populations because it can determine the availability and accessibility to food, water and shelter (Tyrväinen et al., 2005; McComb, 2015). Habitat creation and enhancement, through managing and expanding the urban forest, increases biodiversity and compliments the many other beneficial functions of the urban forest (Dwyer et al., 1992; McComb, 2015).

\subsection{2: Economic Impacts of the Urban Forest}

The economic impacts that urban trees have are mainly through their ability to conserve energy (Dwyer et al., 1992). Continued concern for the environment, including global climate change, has renewed interest in energy conservation and efficiency (Laverne \& Lewis, 1996). Urban trees contribute to energy conservation because they help to reduce the cost of heating and cooling buildings year-round, resulting in less electricity and fossil fuel use (Dwyer et al., 1992; Simpson \& McPherson, 1996). In winter months, properly placed trees can reduce residential energy use by slowing and diverting cold winds (Laverne \& Lewis, 1996; Pandit \& Laband, 2010). Tree canopies over homes provide protection by collectively slowing wind speeds and reducing infiltration of cold air into houses (Laverne \& Lewis, 1996). The extent of this wind breaking effect depends on factors such as the climate, and tree size and arrangement (Simpson $\&$ McPherson, 1996). Large trees in rows, arranged to intercept prevailing winds, can provide the most energy savings, as improperly placed trees can be detrimental to energy conservation (Simpson \& McPherson, 1996). In summer, decreased solar thermal gain resulting from direct tree shade can reduce energy used for air conditioning (Simpson \& McPherson, 1996). Trees cast shade on homes and buildings, lowering the inside temperatures and thus reducing the demand 
for power to cool these buildings during hotter times of the year (Pandit \& Laband, 2010). Trees are most effective when located to shade air conditioners, windows or walls, and when located on the side of the home receiving the most solar exposure (Simpson \& McPherson, 1996).

Urban residential and street trees are assets to communities as they have a strong positive influence on the aesthetic quality of a neighbourhood and housing sales value (Schroeder, 1989; Dwyer et al., 1992). Environments with natural elements such as trees are highly preferred to urban scenes lacking vegetation (Schroeder, 1989). The presence of natural beauty in urban environments provides serenity and tranquility in neighbourhoods and can increase resident's overall satisfaction with their living conditions (Schroeder, 1989; Wilson et al., 2013). Trees stimulate economic development by attracting new businesses and prospective tenants into neighbourhoods, as they have a strong correlation with selling price, meaning that the number and quality of trees are associated with houses that are sold for more money (Anderson \& Cordell, 1988; Merse et al., 2008). Homebuilders report that new houses on wooded lots are sold more quickly than houses on cleared lots. (Anderson \& Cordell, 1988). Varieties of sizes, colours, and species of trees are preferred by many people, but mature and large trees with high leaf area can increase property value more so than other kinds of trees (Anderson \& Cordell, 1988; Schroeder, 1989; Escobedo et al., 2014). According to the USDA Forest Service, healthy and mature trees in and around housing can increase property values 10\% to 23\% (Merse et al., 2008). More conservative estimates state that property value increases can range from $3.5 \%$ to 5\% (Anderson \& Cordell, 1988; Dwyer et al., 1992; Escobedo et al., 2014). The ties between trees and property values provide an incentive for homeowners to invest in trees as they have a bigger effect on property values than other forms of vegetation, like grass or shrubbery, do (Escobedo et al., 2014). When landowners decide not to maintain their properties by not taking 
advantage of the benefits of renovations and planting trees, they lessen the incentive for others to maintain them as well (Heynen, 2006).

\section{3: Gentrification and Urban Forestry}

Over the past century and a half, city governments, civic organizations and neighbourhood associations have invested considerable time and energy building and maintaining parks, gardens and playgrounds (Merse et al., 2008). The expansion of the urban forest has led to many positive benefits in communities around the world, and the role that these trees play in cities has been well documented. However, there is a lack of extensive research done on urban forestry in areas that have undergone gentrification. Studies, such as the ones conducted Merse et al. (2008), Heynen (2006), and Steenberg et al. (2017) help to shed some light on how these two concepts link together.

The study conducted by Merse et al. (2008) focused on the relationship between urban renewal and forestry in Bolton Hill, a neighbourhood in Baltimore, Maryland. The researchers sought to understand if, and how, reinvestment affected the urban forest by looking at historical imagery, analyzing old city documents, and conducting interviews with residents, and city

officials (Merse et al., 2008). What they determined was that the area had minimal trees prior to World War II, but those that existed were in very poor health (Merse et al., 2008). During the 1960s, Bolton Hill experienced residential gentrification in the form of housing rehabilitation, and improvements in infrastructure, such as roads, parks and street lights (Merse et al., 2008). The neighbourhood quickly became one of the most desirable districts in Baltimore, 
experiencing large influxes of wealthier citizens (Merse et al., 2008). What the researchers discovered was that the newer residents were dissatisfied in the condition of trees located in the neighbourhood and wanted to work with the city government to initiate tree planting and management programs (Merse et al., 2008). These efforts led to the introduction of a large variety and number of healthy trees into Bolton Hill, creating a larger and more robust urban forest (Merse et al., 2008).

Heynen (2006) adds further insight into the changes of the urban forest in rehabilitated neighbourhoods in his study on land use change and gentrification in Indianapolis, Indiana. Heynen (2006) states that during the 1960s, there was rapid deindustrialization of the city, which resulted in changes in the economy and the structure of the job market (Heynen, 2006). During the 1960s and 1990s, Heynen (2006) noticed that there was a rapid shift from industrial land to residential and commercial land, which was spurred by gentrification that took place during this time. He reported that the gentrified areas of the city were higher income residential areas of the city (Heynen, 2006). He continued his research and looked at the change in the urban forest and canopy cover over the city and determined that the middle and upper income areas of the city had experienced an increase number of trees and tree cover, whereas the lower income areas and industrial areas did not (Heynen, 2006). Heynen's studies have added to the research conducted by Merse et al. (2008), suggesting that there are a larger number of trees in neighbourhoods that have undergone gentrification.

Research conducted by Steenberg et al. (2017) differs from the work done by Heynen (2006) and Merse et al. (2008). Like this thesis research, the study by Steenberg et al. (2017) focuses on gentrification and urban forestry change within Toronto, Ontario, specifically the Harbord Village neighbourhood. Using tree inventory and building permit data, Steenberg et al. 
(2017) were able to determine to what extent building renovations and rental housing effected tree mortality and tree planting. The researchers found that tree planting was positively correlated with building permits solely along street sections, while multi-unit parcels had lower rates of tree planting (Steenberg et al. 2017). Furthermore, Steenberg et al. (2017), found that higher instances of building permits and housing renovations led to higher tree mortality. This research concludes that areas experiencing changes in housing stock also see losses in trees and their associated benefits (Steenberg et al. 2017).

Gentrified neighbourhoods exhibit a variety of characteristics, the most common includes renovated homes, redeveloped infrastructure, and influxes of wealthier, educated, and younger residents. All of these changes have an affect on the environment, specifically the urban forest, as well. One of the main goals when renovating housing is to make the home more attractive and increase its value (Baum, 1993; Wyly, \& Hammel, 1999). This effects the urban forest as increasing the beauty of a home can involve planting trees, as they have been proven to improve the attractiveness of the urban landscape (Anderson \& Cordell, 1988; Firehock, 2015; Johnston, 2015). Healthier and more exotic species of trees can be added to these homes to make the house stand out for potential buyers. Healthier trees are much more attractive than damaged and deteriorating ones. Trees in poor condition, such as those that lean or have dead or broken branches, are not as appealing as healthy ones, which offer improved environmental, economic and social benefits. Exotic tree species can be introduced into the neighbourhood to make homes stand out against others. When neighbourhoods have uniformity in species, the urban landscape begins to appear plain (Endress, 1990). However, when homeowners plant trees that are considered more exotic or ornamental, where branching patterns or leaf colour are more unique than other trees, the home and the urban landscape becomes more attractive. 
High income citizens who purchase and reside in these attractive modern homes cause a social and economic change in the city as the neighbourhood slowly changes from a lower income to a middle-income area (Beauregard, 1986). These citizens want to maintain their homes and keep a financially secure position in the housing market as deteriorated homes lead to depreciation in property value (Beauregard, 1986; Baum, 1993). Trees have a positive correlation with the value and aesthetic quality of a home (Anderson \& Cordell, 1988; Schroeder, 1989). This positive correlation gives homeowners incentive to take better care of the trees outside of their home (Anderson \& Cordell, 1988; Schroeder 1989). As more housing is renovated, more trees are added to the urban forest, aiding in increasing the average condition and variety and number of species within the area.

Along with the changes in demography and housing, gentrified neighbourhoods also experience improvements to infrastructure, such as waste water systems, streets, and parks. (Lees et al., 2008; Kaplan et al., 2009). These improvements are all essential elements of a neighbourhood, as they are all vital to the physical and economic well-being of the city. Urban parks play a key role in maintaining the urban forest canopy within a neighbourhood. When the city chooses to invest money into improving parks, older trees, unhealthy trees and trees not suited for the urban environment may be removed and replaced with newer, healthier and more robust trees. This not only improves the quality of the environment, but, much like home renovations, serves to increase the beauty of the neighbourhood as well (Merse et al. 2008; Wolch et al., 2014). 


\section{4: Tree Species and Health}

By examining the condition and variety of species of trees, it is possible to understand how gentrification has affected the urban forest. The structure of the urban forest is constantly changing, and trees are an important part of life as they are essential to the long-term prosperity and well-being of mankind (Endress, 1990). However, urban environments can be stressful, and low species diversity may leave the urban tree population vulnerable to new stresses (Sun, 1992). Species uniformity causes not only aesthetic bleakness but leaves the forested landscape vulnerable to the new environmental challenges and diseases that frequently threaten the urban forest (Endress, 1990). Enriching species diversity is important as a greater variety of trees can ensure that the urban forest not only survives, but thrives (Endress, 1990; Sun, 1992).

The survival of the urban forest also depends heavily on the care and condition of trees. The long-term health of trees is important because healthier trees have greater ecological, social, economic benefits (Nowak et al, 1996; Nowak et al., 2010). Various issues, such as insects, diseases, physical injuries, and climate conditions can reduce the health and value of the urban forest (Nowak et al. 2010). Removing hazardous trees and controlling health problems is integral to maintaining the urban forest as benefits that trees provide can decline if the health of trees declines (Schroeder, 1989). By collecting tree species and tree health data, improvements for comprehensive urban forest planning and management can be made (Nowak et al., 1996).

Obtaining tree health and species data can be done in a variety of ways, and many researchers have used reliable methods, such as tree inventories and questionnaires, to gain accurate data regarding the changes occurring in the urban forest. 
Interest in conducting tree inventories has increased over many years as this method is an effective way of gaining a vast amount of information on urban trees (Cumming et al., 2008). As more comprehensive techniques are developed, inventories become a basis for understanding the diverse urban forest and how it changes over time (Dwyer et al., 2002). Studies, such as those conducted by Chacalo et al. (1994), Sjöman et al. (2011), Sreetheran et al. (2011), and Cowett and Bassuk, (2014), all use the tree inventory method as a part of their research to investigate the urban forest. The studies conducted by Sreetheran et al. (2011) and Chacalo et al. (1994) used the tree inventory method to collect data on street tree health and species in Kuala Lumpur, and Mexico City, respectively. Cowett and Bassul (2014), and Sjöman et al. (2011) used this method of data collection to investigate tree species variety. Cowett and Bassul (2014), focused on the state of New York, while Sjöman et al. (2011), investigated 10 different Nordic cities: Aarhus, Copenhagen, Espoo, Helsinki, Tampere, Turku, Gothenburg, Malmo, Stockholm, and Oslo. Each of these studies focused on different areas of the world, but all used the tree inventory method to accurately gather data regarding the health and species of trees.

The above studies illustrate why tree inventories are a useful tool when gathering information regarding the urban forest. While this method of data gathering is invaluable, questionnaires can be used to supplement tree inventories by garnering information from sources that a tree inventory cannot. Questionnaires are very useful as large amounts of data can be collected in a relatively short period of time. Studies, such as the ones conducted by Lohr et al. (2004), Balram and Dragicevic (2005), and Wilson et al. (2013), show how questionnaires can be effective in collecting information about trees and housing changes. The studies Lohr et al. (2004) and Balram and Dragicevic (2005) focus on resident's attitudes towards trees and urban spaces. Lohr et al. (2004) focused on the 112 different metropolitan cities in the United States 
and conducted phone-based interviews with residents in these cities. The study conducted by Balram \& Dragicevic (2005) focused on Montreal, Quebec, and used mailbox drop method for distributing questionnaires. As opposed to focusing on trees and their associated benefits, Wilson et al. (2013) focused on housing changes and the underlying reasons that homeowners in the United Kingdom choose to conduct renovations on their home. Wilson et al. (2013) used two survey methods in gathering information for the study. Wilson et al. (2013) first handed out surveys door to door across the UK. Wilson et al. (2013) then conducted phone interviews with those residents that completed and returned the survey. Using a combination of tree inventory and questionnaire methods, it is possible gather information on the changes and physical quality of the urban forest, while understanding the actions, thoughts, and opinions that residents have regarding trees in their neighbourhood. 


\section{Chapter 3: Objective}

The objective of this study was to evaluate the changes in condition, number, and species of trees in the gentrifying neighbourhood of the Junction Triangle in Toronto, Ontario. The physical and socio-economic changes that gentrification causes have been well documented, but there is minimal literature available on the relationship between urban forestry and the process. This thesis research helps to show some of the positive and negative changes in the urban forest that are attributed to gentrification. In Chapter 2, gentrification was discussed as a cause of physical changes in a neighbourhood, as newer housing is built, older housing is renovated, and improvements are made to streets, parks, and other infrastructure, all with the intention of fixing issues and increasing the appeal of the area (Lees et al., 2008; Kaplan et al., 2009; Wolch et al., 2014). Research that has observed the beginnings of gentrification in the 1960s suggest that the process takes several decades to fully change both the physical and demographic aspects of a neighbourhood (Clay, 1979; Hackworth \& Smith, 2001). However, research on more modern instances of gentrification in various cities suggests that areas are changing more quickly than before due to technological advances and rapid urban development (Lees et al., 2008). Although literature does not give an exact time frame for gentrification, the process can take many decades for the complete transformation of an area (Lees et al., 2008).

The physical changes that are attributed to gentrification also influences the socioeconomic characteristics of a neighbourhood as well, as homeowners sell and rent out their homes to high income citizens while many lower income residents are driven out (Beauregard, 1986; Lees et al., 2008; Kaplan et al., 2009). Lower income individuals tend to have a negative view towards gentrification, as they can no longer afford to live in the revitalized neighbourhood and must go out to look for more affordable living (Beauregard, 1986; Kaplan et al., 2009). 
While these citizens view the process negatively, many newer and higher income residents find the improving neighbourhood beneficial, due to amenities such as increased housing value, access to employment, transportation, recreation and entertainment (Beauregard, 1986; Kaplan et al., 2009).

The physical and demographic changes associated with gentrification also affects the urban forest, as increased presence of trees has a positive correlation with the value and aesthetic quality of a home (Anderson \& Cordell, 1988; Schroeder, 1989). This positive correlation gives homeowners incentive to take better care of the trees outside of their home (Anderson \& Cordell, 1988; Schroeder 1989). Healthier trees are much more attractive than damaged and deteriorating ones (Anderson \& Cordell, 1988; Wolch et al., 2014). Trees in poor condition, are not as appealing as healthy ones, which offer improved environmental, economic and social benefits. (Anderson \& Cordell, 1988; Dwyer et al., 1992; Nowak et al., 2006; Wolch et al., 2014). Along with healthy trees, a larger number of trees and species also have a positive effect on property value as well (Anderson \& Cordell, 1988). Exotic tree species can be introduced into the neighbourhood to make homes stand out against others, as regions with species uniformity create a bleak and plain urban landscape (Endress, 1990). As urban trees preform many critical services for residents, municipalities have a renewed interest in developing the urban forest (Merse et al., 2008; Wolch et al., 2014). When the city chooses to invest money into improving parks, older trees, damaged trees, and trees not suited for the urban environment may be removed and replaced with newer, healthier and more robust trees (Wolch et al., 2004). This not only improves the quality of the environment, but, much like home renovations, serves to increase the beauty of the neighbourhood as well (Merse et al. 2008; Wolch et al., 2014). Using a combination of methods, which is discussed in detail in Chapter 4, it was possible to gather 
information on the changes in the urban forest. From the past research discussed, four main hypotheses were derived and tested during this study:

1. The newer residents who have moved in after 2007 have a more positive view towards gentrification than residents who have lived in the study area for a longer period of time;

2. Gentrification is associated with a greater number of trees and tree species in the study area;

3. Trees in front of homes that have been improved are in better condition than those located in front of unimproved homes.

4. Trees located in front of homes are healthier than public land trees.

Studying urban forestry in a gentrifying neighbourhood is important because it can provide an understanding of the environmental consequences of gentrification. The two methods that have been used to test the above hypotheses include a tree inventory of the neighbourhood, and questionnaires that focused on gentrification and urban trees. Chapter 4 will discuss these two approaches in more detail. Hypothesis number 1 was tested mainly using the questionnaire, while the last three hypotheses were tested mainly using the tree inventory method. The third and fourth hypothesis were then analyzed statistically to determine differences between the groups. The tree inventory method gathered accurate data regarding the number, health, and variety of species of trees within the neighbourhood, while the questionnaire approach gave detailed information regarding age, time living in the neighbourhood, and resident's thoughts and opinions regarding gentrification. The first hypothesis specifies the year 2007 as a previous study was conducted in the study area in that year. Therefore, 2007 was chosen as a benchmark year to keep the dates consistent between this thesis research and the previous study. Literature and 
studies of gentrification do not give an exact timeframe from the beginning to end of gentrification. The study area in which thesis research takes place exhibits evidence of the physical and socio-economic changes associated with gentrification, which is discussed in detail in section 5.1. However, as of the completion of this thesis research, not all changes that a gentrifying neighbourhood experiences have been fully realized in the study area. Quicker changes, such as construction and the damage associated with it, are much more apparent. However, other changes, such as changes in resident attitudes towards trees, and city decisions regarding tree planting, evolve over longer periods of time. Although 10 years of time offers a good quantity of information, the process of gentrification has yet to fully transform the study area. 


\section{Chapter 4: Methods}

The neighbourhood in which this study took place is called the Junction Triangle. The neighbourhood is located in mid-west Toronto, roughly in the area of Bloor Street West, Dundas Street West, Dupont Street, and Lansdowne Avenue. Figure 1 and 2 show the Junction Triangle and its location within the City of Toronto. The Junction Triangle was chosen as the area of focus for this thesis research for two reasons. First, the neighbourhood is currently undergoing residential gentrification in the form of renovated housing and the development of new housing stock (section 5.1 discusses the physical, social, and economic changes associated with gentrification in the area). Furthermore, this neighbourhood was also the subject of a previous tree inventory conducted in 2007, which gathered information regarding the location and variety of tree species within the area.

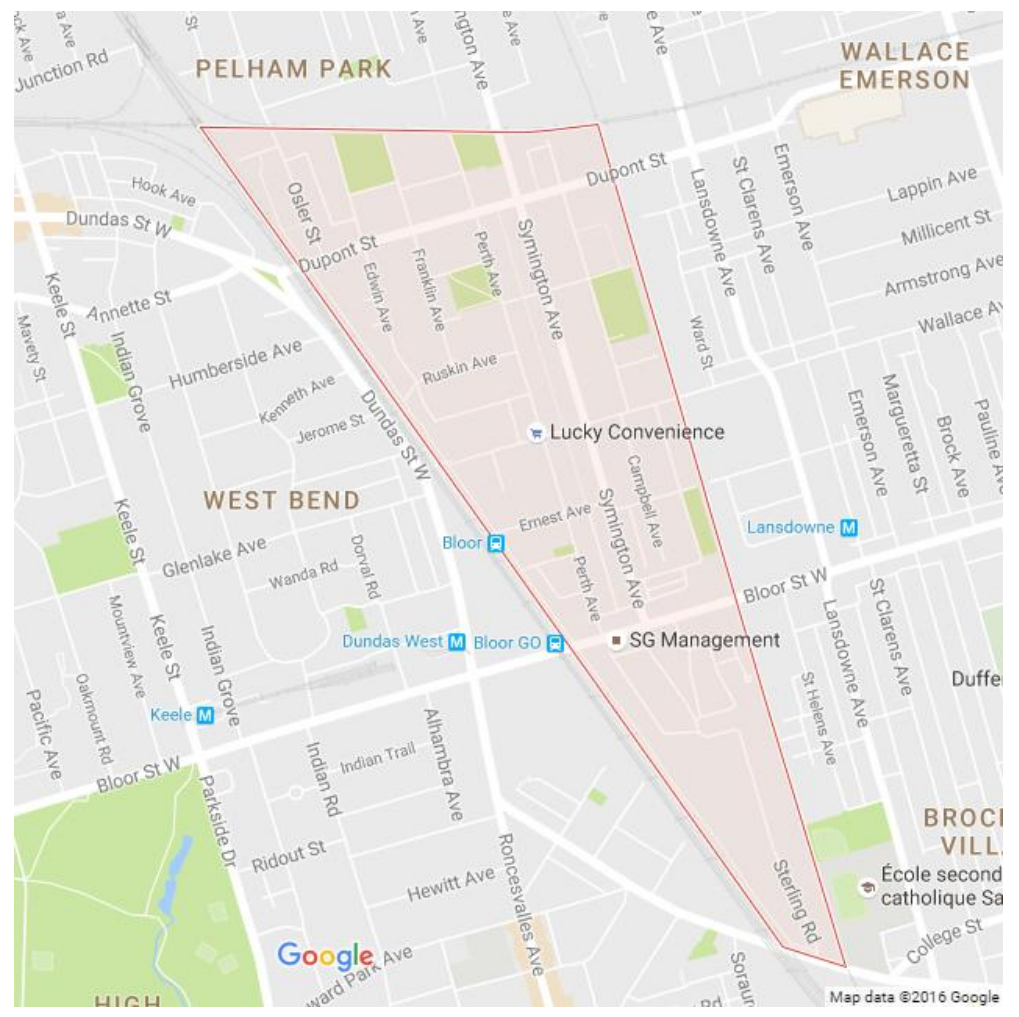

Figure 1: The Junction Triangle (Google Maps, 2016a). 


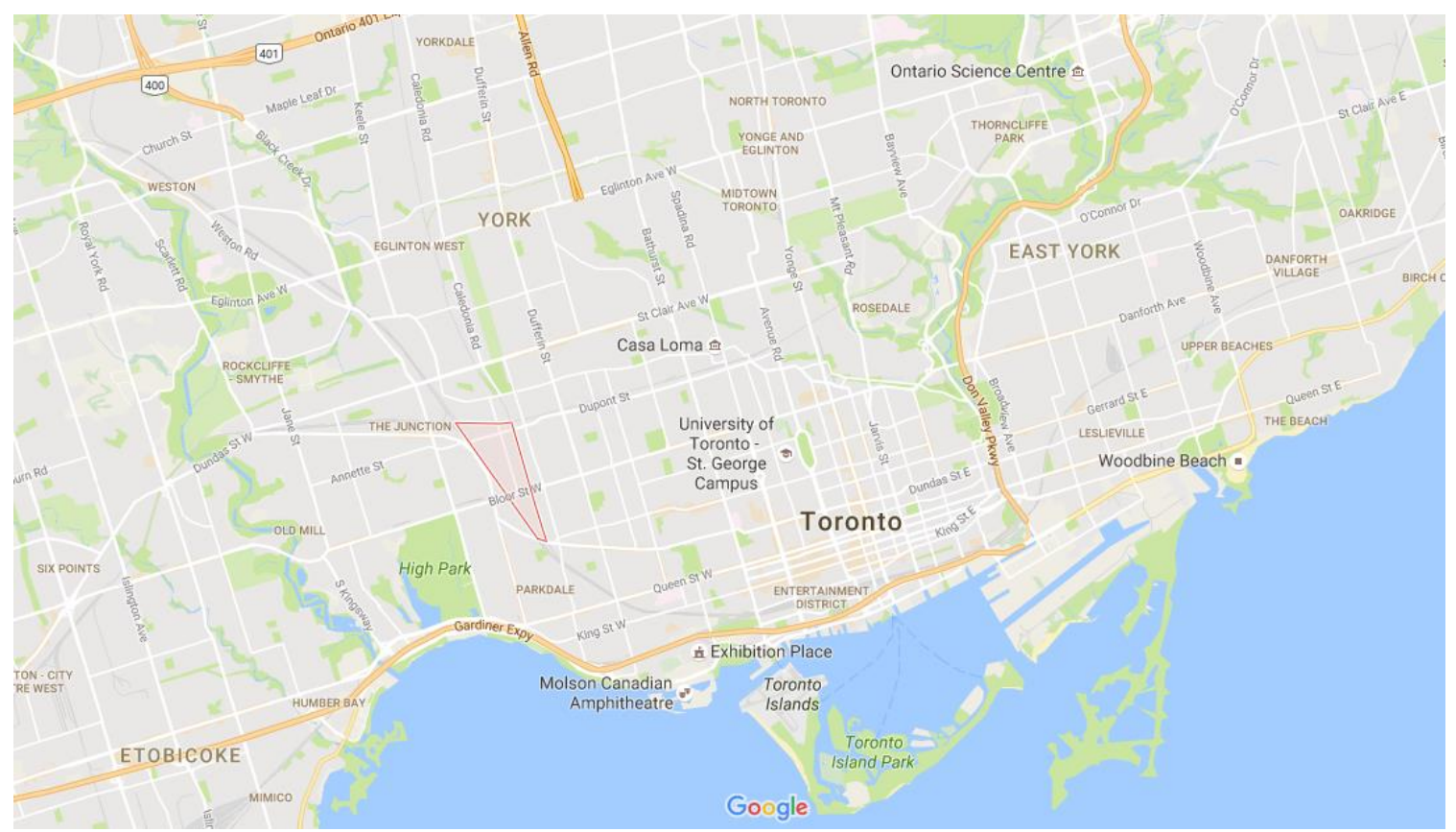

Figure 2: The Junction Triangle within the City of Toronto (Google Maps, 2016b).

\section{1: Tree Inventory}

A tree inventory is a collection of information and data regarding the trees in an area. Typically, an inventory will include data such as tree species, tree condition, diameter at breast height, crown density and symmetry, soil condition, location, and many other features.

\subsubsection{Green Here Inventory}

A tree inventory in the Junction Triangle was conducted by the urban forest protection and conservation organization, Green Here (no date), in 2007. Green Here recruited volunteers from the neighbourhood, and worked with another local organization, Neighbourwoods, to train them. Neighbourwoods was created by University of Toronto professors Dr. Andy Kenney and Dr. Danijela Puric-Mladenovic for the purposes of helping citizens and governments alike conduct simple and accurate tree inventories (Kenney, 2006). Some of the cities that have used 
the Neighbourwoods tree protocols include Thunder Bay, Cobourg, and Windsor

(Neighbourwoods, no date). To confirm the validity of this tree inventory, Dr. Puric-Mladenovic was contacted through e-mail. Dr. Puric-Mladenovic explained that she and Dr. Kenney had trained Green Here representatives and volunteers in the collection of data, such as tree species, location and condition. When the data was collected, the information was compiled and displayed on the Green Here website. Dr. Puric-Mladenovic stated that her involvement with the inventory was limited to training volunteers and did not participate in the actual collection of data.

The inventory was conducted by Green Here during the summer of 2007. The organization used volunteers from the area, ranging in age from young adults to older citizens. Each volunteer was trained in tree data collection by Neighbourwoods' founders Dr. Andy Kenney and Dr. Puric-Mladenovic. Green Here informed the residents of the Junction Triangle of their intention of studying the trees in the neighbourhood by posting on the neighbourhood's webpage: junctiontriangle.ca. The volunteers covered the entire neighbourhood, collecting information about the trees located on boulevards, parks, and around buildings and homes. Trees behind fences, gates and in backyards were also accessed by these volunteers, through permission granted by landlords and property owners. The area of south of Bloor Street, seen in Figure 1, is industrial land that did not contain any trees, and was taken out of the study. Each volunteer collected information regarding the species, health and location of trees. The information was subsequently compiled and distributed through the Green Here website in map form. Dots were plotted across the map, where each dot represented the location of an individual tree, along with information about the trees species. Although individual health information was 
collected during the inventory, this information was not provided, but instead an indication of the average health of trees in the neighbourhood as a whole was displayed.

Unfortunately, in 2016 the Green Here website was taken down and all tree information regarding the neighbourhood was deleted. However, before the website was taken down, the data and maps were saved and used in this thesis research to complete an updated tree inventory in 2016, which is discussed in detail in section 4.1.2. Figure 3 shows the locations of these trees collected by Green Here within the neighbourhood. The neighbourhood is bordered in black, while the study area of this thesis research is bordered in red. Each dot represents a single tree, and dots outside of the borders are trees in other neighbourhoods, conducted during different inventories by the same organization.

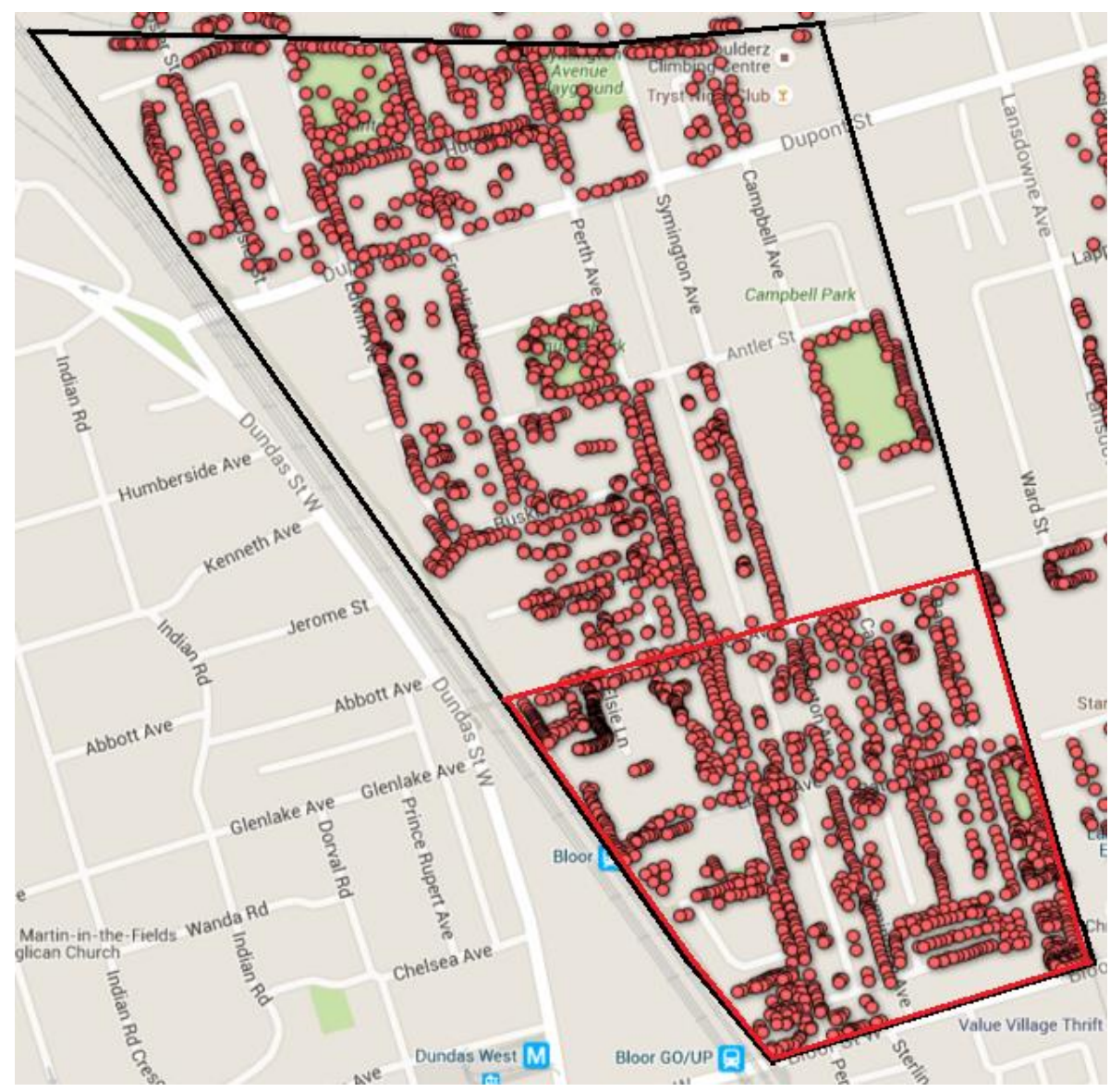

Figure 3: The 2007 tree inventory (Green Here, no date). 
The information that was collected in 2007 inventory showed that there were 2015 trees and 87 different species across the Junction Triangle (Green Here, no date). Of these 2015 trees, approximately $48 \%$ were owned by the city, located on streets, and parks, while $52 \%$ were located in front of homes, public road allowances, and backyards (Green Here, no date). During this inventory, the most numerous tree species included Manitoba maple, tree of heaven, Norway maple, eastern white cedar, and cherry plum tree (Green Here, no date). These species make up approximately $53 \%$ of the trees in the entire neighbourhood.

\subsection{2: Updated Tree Inventory}

During the summer of 2016, an updated tree inventory of the Junction Triangle was completed. The purpose of the tree inventory was to test hypotheses 2,3 , and 4 , by investigating how gentrification has affected the number, species, and condition of trees in the neighbourhood. One of the main pieces of evidence of gentrification is renovated housing (Helms, 2003). Housing that has been renovated is done so for many reasons, such as increasing its attractiveness, repairing physical issues, increasing sales value (Baum, 1993; Wyly, \& Hammel, 1999; Wilson et al., 2013). Healthier and more unique species of trees are added to these homes for the purposes of increasing beauty and desirable to future buyers. Trees in good condition are more attractive than damaged ones, as those with damage do not offer the same appeal or environmental, and economic benefits as those in good condition. Unique and exotic tree species introduced into the neighbourhood are done so to make homes stand out against others. As a neighbourhood gentrifies, more housing is renovated, and more trees are added to the urban forest canopy, assisting in increasing the condition, number, variety of species within the area. 
In order to determine which vegetation was to be included in the tree inventory, it was necessary to establish the definition of a tree. For the purposes of this research, a tree is defined as any species of plant which has a single wood stem protruding from the soil, branching out into a well-formed crown of foliage (Sibley, 2009). Many authorities also include a height requirement for a plant to be considered a tree. However, in this thesis research a height requirement was not used. As many species of trees recorded during the tree inventory were newer trees or saplings, removing these trees due to their height would diminish the total number of trees in the study area by several hundreds.

Due to limitations, such as time and manpower, an inventory of the entire Junction Triangle neighbourhood was not feasible for this thesis research. The inventory was limited to the area south of Wallace Avenue, highlighted in red in Figure 3. This study area contained 933 out of the 2015 trees recorded during the 2007 inventory, as well as 60 of the 87 species. Trees located in backyards have not been included in this thesis research due to impediments such as trespassing and locked gates and fences. To make the two inventories more comparable, backyard trees for the 2007 inventory had been removed, which brought the total number of trees and species in the study area down from 933 trees and 60 species, to 802 trees and 54 different tree species. In this thesis research, trees have been split up into trees located on public land, and trees in front of homes. Trees on public land have been split into trees along boulevard strips, trees located in parks, and trees along the West Toronto Railpath. Boulevard trees are trees that line streets or avenues, while parks trees are those planted in city parks and green spaces. Trees along the West Toronto Railpath are those that are adjacent to the Bloor GO/UP Express metro line. The railpath is a foot trail that runs next to this metro line and is of environmental significance to the neighbourhood. The railpath not only is bordered with dense vegetation, with 
a large number of trees and tree species growing here, but is designed to encourage encourage environmentally and physically healthy activities for residents of the area, as pedestrians, runners, and cyclists frequent the path (Kern, 2014). The construction of the railpath is a major change of the neighbourhood and its addition has helped recognise the Junction Triangle as a mobility hub (City of Toronto 2013; Metrolinx, 2015). A mobility hub is defined as an area of the City that has significant connectivity to other major transit stations, while also having high residential and employment development potential (City of Toronto 2013; Metrolinx, 2015).

Over the years since its construction, the metro line has continuously undergone redevelopment in order to increase efficiency, comfort, and aesthetics (City of Toronto 2013).

Along with trees located on public land, trees in front of homes have been categorized as well. Within the City of Toronto, the size of the land in front of a home varies, making it difficult to distinguish whether it is private or public property. Depending on the location within the city, trees growing in front of a home may be publicly owned, while others may be privately owned. Unfortunately, a standard for measuring the property line and right of way is not listed on the City of Toronto's website anymore due to these issues in the size of front yards in different areas of the city; thus, a feasible way of obtaining this information was by contacting the city directly. To determine the property line for homes in the Junction Triangle, the City of Toronto's transportation services division and right of way management was contacted. Within the Junction Triangle, the city owns the entire front yard for all homes in the neighbourhood, including the study area in which this thesis research takes places. For the purposes of this research, trees in front of homes were categorized separately from other public land trees, such as boulevards and parks. This is because homeowner's can still make decisions regarding the trees in front of their 
home, such as submitting requests for removal or addition, as well as tree maintenance and care decisions.

Like public land trees, trees in front of homes have been split into sections as well. These trees have been categorized by the type of housing that they are planted in front of. The housing types within the study area include row homes, stacked townhomes, low-rise apartments, and semi-detached homes. Row houses consist of rows of dwellings joined on both sides, but do not have any other dwellings above or below them (Statistics Canada, no date). Each row home typically has a front and backyard (Madi et al., 2015). Stacked townhomes are dwellings that share a sidewall and have units stacked vertically above one another (Madi et al., 2015). Low rise apartments are dwellings that are less than four storeys high and share interior corridors, vertical circulation and entrances, and have multiple units stacked vertically (Madi et al., 2015). Finally, semi-detached homes are pairs of homes, attached together by a common wall, but are not attached to any other dwelling or structure (Statistics Canada, no date). Semi-detached homes have no dwellings above or below it, and the two units have open spaces in the front and back (Statistics Canada, no date).

Semi-detached homes were then further categorized between homes that were renovated, and homes that were declining in quality. Both the exterior and interior portions of homes can have renovations conducted on them, but for the purposes of this thesis, only the exterior portions were examined as these changes would affect the urban forest the most. Research conducted by Hammel and Wyly (1996), classify homes as improved or unimproved based on visually identifiable evidences of reinvestment and renovations. These indicators include structural soundness, reconstruction of latticework, gutters, steps porches, windows and frames, and fences, sandblasted brick, paint, and prominent entryway and signage (Hammel and Wyly, 
1996). Homes that have these visible evidences of reinvestment are classified as improved. The importance of renovations is not only to make the home look good but to fix issues and maintain the structure. Unimproved homes that have not had renovations or repairs done to them can begin to visibly physically deteriorate (Baum, 1993). In the study area, there are a mix of improved homes and unimproved homes. The City of Toronto was contacted to obtain information regarding permits that were acquired by homeowners for renovations. Unfortunately, permit data was not attained as it would yield incomplete and inaccurate data. Many homeowners had obtained permits for larger scale projects. However, other owners, who perform smaller scale renovations, do not always obtain permit data. Due to this, obtaining permit data from the City would not give accurate results on the proportions of homes that have been improved or unimproved. The method that was used in this thesis research was to go through the neighbourhood during the inventory and examine each semi-detached home and look at the visible changes outlined by Hammel and Wyly (1996), or physical deterioration, and record whether the home was improved or unimproved.

While investigating each home for signs of renovation, trees were examined as well. In order to complete the updated inventory in 2016, the maps from the Green Here webpage, before it was taken down, were printed and used to navigate the neighbourhood and revisit trees. The dots on the map were labeled to help identify which species of tree each dot was. The inventory recorded new trees, trees that were still there between 2007 and 2016, and trees that had been cut down. Each tree in the study area was approached and its species, condition, rating, and location were recorded. Field notes about the area surrounding the tree, such as type of housing and nearby construction, were also taken as these features have an influence on the condition or species of trees. 
Each individual tree during the inventory was approached and its species was identified and recorded. Species identification requires the analysis of the physical features of a tree. During the inventory, the leaves, bark, twigs, flowers, and fruit of trees were inspected. As many trees have similar features, inspecting only one of these features is not enough to accurately determine the species of tree. By examining the combination of these physical features, it was possible to minimize the inaccuracies during the identification process. The Sibley Guide to Trees (Sibley, 2009) and the Ontario Tree Atlas (Government of Ontario, no date) were two resources that were used to identify individual trees in the study area. The Sibley Guide to Trees (Sibley, 2009) is a written database of all native and non-native trees in North America, while the Ontario Tree Atlas (Government of Ontario, no date) is an online database focusing only on native trees to the forests of Ontario. Both of these resources offer detailed descriptions of trees including leaves, fruit, flowers, twigs, buds, bark, size, habitat, and soil preferences. By using both of these resources it was possible to visit each tree in the study area and determine the species of each tree. If there was any confusion or hesitation regarding the identification of species when visiting the tree, samples of leaves, fruit, or flowers were taken from them to be analyzed later when more time was available to minimize errors and ensure the correct identification of trees. Species identification was also performed on the trees that were still present from 2007. This portion of the thesis research was able to confirm that the all the trees and species identified in 2007 that were still present during the 2016 inventory were all correctly identified. Confirming the species of trees from the 2007 inventory is important as it validates the older survey and its accuracy, as well as the reasoning for its use as a yardstick for this thesis research. 
After identifying the species of tree, the condition was assessed and recorded.

Determining tree condition was done examining the various physical defects visible on the surface of the tree, as well as the number and severity of these injuries (Bernhardt \& Swiecki, 2001; Stolte et al, 2002). Research conducted by Albers and Hayes (1993), Albers et al. (2012), and Angwin et al. (2012) were consulted to aid in the assessment of tree defects and injuries. These studies detail the many visible injuries that trees can suffer and provide detailed guidelines to determine the severity of each injury. Using these resources, it was possible to examine each tree during the inventory, and assign a rating, which represents the health of the tree, based on the number and severity of the trees injuries. The studies list the most common injuries that negatively impact the health of trees, which includes cracks, weak branch unions, cankers, decaying, dead, or broken branches, and tree lean (Albers \& Hayes, 1993; Bernhardt \& Swiecki, 2001; Stolte et al., 2002; Angwin et al. 2012).

A crack is a deep split or fissure in the main stem of a tree and extends deep into the wood (Albers \& Hayes, 1993; Albers et al., 2012). This tree defect is easily visible as a split through the bark that extends into the wood of the tree (Albers et al. 2012). Cracks can be generated in two ways: 1) from short-term injuries, such as storm damage or mechanical damage, or, 2) from improper wound closure over a period of years (Albers \& Hayes, 1993). The health of the tree is determined by the severity and number of the cracks on it. A crack that is extremely severe exhibits features such as the crack being 4 inches or over in length, the crack going completely through the stem, the stem having two or more cracks on the same segment, and the stem containing the crack being in contact with other defects, such as cankers, lean, or wood decay (Albers \& Hayes, 1993; Angwin et al., 2012). Low to moderately severe cracks are 
smaller than 4 inches, have no wood decay, and are not associated with other defects (Angwin et al., 2012).

A branch union is a fork in the stem or a place where two or more branches join the stem together (Angwin et al., 2012). Strength of the branch union is determined by whether the wood in the union is well connected or has become entrapped (Angwin et al., 2012). Branch unions can become weak when two or more similarly sized, usually upright branches grow so closely together that bark grows between the branches inside the union (Albers et al., 2012). If the bark has become entrapped by the expanding wood of the branches, it acts as a wedge and prevents the wood of the branches at the union from fusing together (Angwin et al., 2012). As an increasing amount of bark is included inside the tree, the remaining woody connections between branches cannot support the weight of the branch and weak union begins to fail (Albers \& Hayes, 1993). Branch unions that can negatively affect the health of the tree and create a high potential for failure depict features such as a v-shaped union that is cracked, cankered or decayed, or the weak branch union forms on the main stem of the tree (Albers \& Hayes, 1993; Albers et al. 2012, Angwin et al., 2012). Branch unions that are less severe usually have a ushape, and the union has inrolled bark (Angwin et al., 2012).

A canker is a localized area on the stem or branch of a tree where the bark is sunken or missing (Albers et al., 2012). Cankers can be caused by fungi, insects, disease, weather, fire, or mechanical damage (Albers \& Hayes, 1993; Albers et al. 2012; Angwin et al., 2012). There are two types of cankers: annual and perennial (Albers \& Hayes, 1993). Annual cankers are injuries or short-lived infections which do not affect the tree's structural integrity, where as perennial cankers are long term infections that can alter the tree form and structure (Albers \& Hayes; 1993). Trees with severe cankers exhibit features such as cankers with internal wood decay, 
cankers connected to cracks, cankers affected more than half of the tree's circumference, multiple cankers with internal decay (Albers \& Hayes, 1993; Angwin et al. 2012). Cankers with low to moderate severity affect one third to half of the trees main stem, have no internal wood decay, or are not associated with any other defect (Angwin et al., 2012).

Decaying, dead, or broken branches are one of the leading causes of tree failure as dead and highly decaying branches can be unpredictable and can fall at any time (Albers et al., 2012; Angwin et al., 2012). Decaying and dead branches may remain attached to trees for several years or may fall off suddenly (Albers \& Hayes 1993). Branches that are severely decaying and have a high potential for failure depict characteristics such as internal decay in conjunction with fungus, insects, and other defects, such as cracks or weak branch unions, branches that are dead or decaying in more than two thirds in length (Angwin et al., 2012). Less severely injured branches may still show signs of decay and breaks but affect less than two thirds of the branch (Angwin et al., 2012).

Trees that experience lean, typically do so due to weather conditions, such as windstorms, snow, and ice buildup, or by damage from nearby construction (Albers et al., 2012; Angwin et al., 2012). These conditions damage the root system beneath the ground, giving the tree a displaced centre of gravity, increasing the chances for the tree falling over (Angwin et al., 2012). Trees with a severe lean, and high potential for failure, exhibit features such as trees with an angle of $45^{\circ}$ or greater, lean with other contributing defects such as cracks or cankers in the main stem, leaning that lifts or cracks the soil near the base of the tree, and uncorrected lean by an unbalanced crown weighted in the direction of the lean (Albers \& Hayes, 1993; Angwin et al., 2012). Trees experienced low lean severity display characteristics such as lean between $10^{\circ}$ and 
$45^{\circ}$, branches with a twist or bend, and branches that are lopsided or unbalanced with respect to the rest of the crown (Albers \& Hayes, 1993; Angwin et al., 2012).

Using the information and guidelines from previous research, it was possible to give a rating that best represented the health of the trees during the inventory. The ratings makes it clear which trees were in better condition, and which were worse and in need of immediate care. Rating systems have been created by many organizations to aid tree arborists, researchers, and communities understand the health of the urban forest in the area. Numerical ratings allowed the calculation of average health of trees in different parts of the study as well as aided in testing hypotheses number 3 and 4 . There are many rating systems in existence, such as ones created by the Council of Tree \& Landscape Appraisers (Cullen, 2007), Neighbourwoods (no date; Kenney, 2006), and the USDA Forest Service (Angwin et al., 2012).

The Council of Tree and Landscape Appraiser's (CTLA) is a consortium of North American organizations focused on environmental preservation and maintenance, such as the International Society of Arboriculture, American Society of Landscape Architects, and the Association of Consulting Foresters (Cullen, 2007). The CTLA's rating system provides methods for the valuation of trees which are generally accepted by arborists, tree officers, and professional appraisers (Cullen, 2007). Valuation is a systematic process of estimating the monetary value of something (Cullen, 2007). In this rating system, valuation is used as a tool by researchers to rate trees not because they are market goods, but because they provide a variety of benefits to the environment, society, economy (Cullen, 2007). This rating system is used to form a basis for rational decisions regarding tree preservation, removal, and replacement (Cullen, 2007). For the purposes of this research, the CTLA rating system will not be used as this assessment system focuses less so on the physical health of trees, but the intrinsic value of trees. 
The Toronto based organization, Neighbourwoods, has created a tree rating system that focuses on the evaluation of the health of trees. The assessment system was developed by Dr. Andy Kenney (2006) and Dr. Danijela Puric-Mladenovic and has been used by many communities and city governments throughout Ontario (Kenney, 2006; Neighbourwoods, no date). The system instructs users to rate tree condition using either a numerical value, from 0 to 3 , or, as many communities have opted to use, by using classes such as excellent, good, fair, and poor (Kenney, 2006). Although the system is designed to be easy to use by communities, volunteers, and amateur arborists, the method will not be used for this thesis research. The methods are not readily available online and requires a two-day orientation and training seminar,and requires the data that has been collected to be sent to the organization for analysis (Kenney, 2006). Due to these restrictions, other methods of tree evaluation have been considered.

The rating system that was used for this thesis research was created by the United States Department of Agriculture Forest Service. The Forest Service is an internationally recognized agency and has created guidelines to identify trees that are likely to fail or cause injury to people or property based on their physical health (Angwin et al., 2012). The Forest Service has combined two separate systems that are traditionally used in rating trees: a risk management assessment and a tree condition assessment (Angwin et al., 2012). For this research, the guidelines detailed in the tree condition assessment will be used, and the risk management section will be disregarded as risk management is not the focus of this study. The tree condition assessment methods, also called the failure potential, requires the inspector to visually evaluate the physical condition of the tree, and note the number and severity of its defects (Angwin et al., 2012). 
During the inventory, each individual tree was approached, and the number and severity of its defects were judged based on the guidelines from Albers \& Hayes (1993), Albers et al. (2012), and Angwin et al. (2012). After examining the tree, they were given a score between 0 and 4, as instructed by the USDA Forest Service rating system (Angwin et al., 2012). These values represent an increasing severity of damage to the tree. The value of 0 represents no visual defects, meaning that the tree is in good health (Angwin et al., 2012). Trees with a value of 1 have sustained very minor or low severity injuries, and do not have a high potential for failure (Angwin et al., 2012). A value of 2 is given to trees that have moderately severe injuries (Angwin et al., 2012). Any tree that has moderate defects, or 2 lower severity defects that are in conjunction with one another, are required to have a value of at least 2 (Angwin et al., 2012). Trees with a value of 3 are given to those who have extremely severe defects or have multiple low or moderate defects in conjunction with one another (Angwin et al., 2012). A value of three means that the tree has a high potential for failure and requires immediate attention (Angwin et al., 2012). The maximum score is a value of 4 and is reserved for trees that are observed to be dead and needed to be removed immediately (Angwin et al., 2012). After all the trees in the study area were assessed and given a rating, it was possible to get mean ratings for the sections of land within the study area.

While assessing the trees condition, the approximate location of new trees and trees still present between the old and new inventory were recorded using a mobile GPS application. The locations of trees that had been removed were also recorded. All locations were written in decimal degrees and were used to create a map of the study area. Along with location, field notes about the surrounding area of the neighbourhood were taken as well. The type of housing and renovation status of housing was collected to test hypothesis number 4. 
Trees that had been recently planted in the study area were recorded as new in the notes section to determine the number of new trees in the study area, and where these trees are located. Trees that were considered new are those that were saplings or had been planted between the 2007 and 2016 inventories. Trees that were not identified as new are older trees that have appeared in the 2007 inventory. Last, if trees were near construction was recorded as well, as these disturbances may have an effect on the future health of trees.

\section{2: Questionnaire}

In addition to the tree inventory, 150 questionnaires were given to the residents of the Junction Triangle study area on a door-to-door basis. Questionnaires and surveys have been used extensively by many researchers as they are an effective way of gathering data from people in a short period of time. Research has shown that response rates for door-to-door surveys tend to be higher than other forms of inquiry, such as phone, online, or mailbox drop off surveys (Nulty, 2008). This form of research typically has a response rate of approximately $56 \%$ (Watt et al. 2002; Nulty, 2008). Some studies have shown even higher response rates for paper-based doorto-door surveys, approximately 75\% (Nulty 2008; Whaley, 2014). Given the response rates estimated by literature, 150 questionnaires will be handed out to the residents of the neighbourhood with an ideal return of $84-112$ questionnaires.

As a part of Ryerson's requirements, the questionnaire used in this research has undergone an ethics review by the Research Ethics Board. The ethics review required a full description of the questionnaire, including research methods, recruitment, consent, confidentiality. The questionnaire has been approved by the Ryerson Research Ethics Board. The 
method of gathering data for this questionnaire involves asking qualitative research questions, which are questions that explore the meaning individuals or groups assign to a certain problem (Creswell, 2003). The questionnaire was used to gain an understanding of the underlying opinions and motivations of respondents, as well as discovering trends in actions and thoughts (Creswell, 2003).

Recruitment for the questionnaire was conducted on a door-to-door basis, and the entirety of the study area was covered when all questionnaires were handed out as the large majority of residents were not home, did not answer their door, or refused to participate in the survey. Questionnaires were handed out in the evenings rather than during the day, as evenings would yield a better response rate due to residents attending work or school during the day hours. Unfortunately, permission by landlords and superintendents was not given to hand out questionnaires to residents of apartments and lofts. The questionnaires focused solely on residents in semi-detached and row homes, as the owners of these homes have more autonomy to plant trees in front of their homes. Residents who live in stacked townhomes or low-rise apartments share the land in front of the building and do not have autonomy to plant trees and conduct renovations. If the resident answered the door, they were asked to complete the survey immediately, or, if more convenient, the questionnaire was left with them with instructions that it would be picked up the following day. If no resident answered the door, another attempt was made the following day. Consent for this questionnaire was obtained by using a written consent form, which was handed out along with the questionnaire. Each resident read and completed the form at their own leisure and was picked up with the questionnaire when both items were completed. The questionnaire involved confidentiality, as no identifying information, such as phone number, e-mail, or home address, was collected or recorded. All the responses are hard 
copy, and after they were collected, were entered into a database. After all questionnaires were handed out, 53 were returned, giving a response rate of $35.3 \%$.

The purpose of the questionnaire was to gain insight into the resident's opinions of trees and the redevelopments currently occurring in the neighbourhood. Furthermore, the questionnaire collected information about any actions they have taken in regard to housing renovation, tree planting, tree removal, and tree maintenance. The questionnaire is a structured survey with closed questions, as they are easy for respondents to answer and for researchers to derive patterns from. Each question has a set of options for respondents to choose from. A Likert scale was used in some of the questions that asked residents about their thoughts and opinions on trees and gentrification. This scale is used widely in many questionnaires as answers are clear and easy to draw conclusions from. The questionnaire that was used in this research can be broken down into three different groups of questions: demography, gentrification, and urban forestry.

The demographic questions focused on the age of the respondent and the ownership status of the home. The questionnaire asked for responses solely from the primary resident, and which age group this respondent falls under. Those under the age of 18 are likely not the primary resident or owner of the home, and therefore cannot make major decisions regarding the renovations of the home or adding and removing trees on the property. Ownership status of the home of the respondent was collected as well, as owners are the ones making these major decisions. Responses from those who rent property were collected, as their responses still provide valuable information regarding forestry or gentrification in the neighbourhood. 
Regarding gentrification, the residents were asked about any renovations conducted on their home, and their feelings about gentrification currently occurring in the neighbourhood. The residents were given a 5 point-scale to rate their view of gentrification, from strongly like, like, neutral, dislike, and strongly dislike. The questionnaire went on to ask why the resident liked or disliked the housing changes occurring in the neighbourhood, with several answers to select from, as well as a space to write down their own response. The purpose of these questions was to determine any patterns in thought among the respondents and discover the underlying reasoning of a respondent's support of, or aversion to, gentrification.

The questions regarding urban forestry asked residents about the benefits associated with forestry, the trees on their property, maintenance activities, the health and value of trees in the neighbourhood, and the new trees in the neighbourhood. The residents were asked if they believed that trees provided environmental benefits to the neighbourhood, and, if so, what benefits they believed to be the most important. For trees outside a home, the questions focused on the decisions surrounding adding or removing trees, if the respondent liked the tree outside of their home, and, if not, what kind of tree they would like instead. The residents were then asked what kind of tree care practices they undertook to ensure the preservation of their tree, including pruning, adding mulch or fertilizer, watering, or contacting the city for maintenance needs.

Regarding trees throughout the neighbourhood, the questionnaire asked residents if they believed that forestry added value to the neighbourhood, if the trees were generally well taken care of, and if they had noticed an increase of new trees in the area. These forestry questions sought to understand the respondent's attitudes towards the tree health and species outside their home, as 
well as throughout the neighbourhood. The full questionnaire used in this study is available in Appendix 3.3.

\section{3: Statistical Analysis}

Using SPSS, Mann-Whitney U tests were conducted to statistically test the results of the tree inventory and gentrification questionnaire results. The Mann-Whitney U test is a nonparametric alternative to the independent samples t-test (McKnight \& Najab, 2010). Both of these statistical tests determine the difference between two groups, but for this thesis research the t-test was not chosen. The t-test is used in research where data follows a normal distribution, while the Mann-Whitney U test does not require the assumption of a normal distribution, and tests for differences for ranked data (Mann \& Whitney, 1947; McKnight \& Najab, 2010). During the inventory, tree condition was collected, and individual trees were rated on a 0 to 4 scale. During the questionnaire, some of the answer choices ranked using a Likert scale. As both the Likert scale questions and tree health ratings are ranked and do not follow a normal distribution; the Mann-Whitney $U$ test is a more appropriate statistical test than the t-test. Using this analysis, the first, third, and fourth hypotheses were tested. The hypotheses were tested by using the data gathered on the sample population of residents and trees within the study area. 


\section{Chapter 5: Results and Discussion}

The results and discussion chapter of this thesis is divided into 3 sections. Section 5.1 discusses the demographic and housing changes that have occurred in the Junction Triangle as a result of gentrification, and the results of the questionnaire that was handed out to residents of the study area. Section 5.2 analyzes the species of trees located on public land and in front of housing and compares the species changes between the 2007 inventory and 2016 inventory. This section further goes on to discuss the tree species section of the questionnaire. Last, section 5.3 looks at the condition of trees located on both public land and outside homes in the study area and examines the tree health portion of the survey.

\subsection{Evidence of Gentrification in the Junction Triangle}

The Junction Triangle is a residential neighbourhood that has been experiencing the process of gentrification. The neighbourhood's name stems from the triangular shape formed by the three rail corridors making up the borders of the neighbourhood. The western border of the neighbourhood is created by the Bloor GO/UP Express metro line. The railway provided transportation for many working-class individuals, particularly during the 1970s as a large number of industrial jobs were located in the Junction Triangle during this time (City of Toronto, 2013). The neighbourhood has a long history of industrial activity, such as automotive, metal processing, lumber, and hardware, which employed approximately 11,500 people (City of Toronto, 2013). The neighbourhood has always been a mixed-use area, with a combination of industrial and residential land uses (City of Toronto, 2013). However, the mix of land uses created many major conflicts that the city needed to address, such as insufficient room for 
expansion, traffic congestion, inadequate buildings, and unfavourable community attitudes (City of Toronto, 2013). To enhance the quality of the neighbourhood, the city began to make major improvements in many sectors, specifically in parks and open spaces, community centres, and streetscapes (City of Toronto, 2013). Slowly, the neighbourhood began to transform, and from the early 1980s, industrial lands in the Junction Triangle began to be abandoned (City of Toronto, 2003). This led to large areas of vacant or underutilized land, where there were opportunities for new housing developments to take place (City of Toronto, 2003). In 2002, city council approved zoning-by law amendments to transform much of the industrial area into residential designations, in order to create new homes, bring in more citizens, and create a more vibrant and integrated community within the neighbourhood (City of Toronto, 2003). The neighbourhood is continuing to change rapidly with a variety of housing changes and new housing developments taking place, as well as improvements being made to parks, transportation, and urban design (City of Toronto, 2013).

Gentrification is currently taking place within this neighbourhood and has resulted in the influx of new residents into the area. This flow of newer residents affects the demographic characteristics of the area as well (Beauregard, 1986; Caulfield, 1994; Kaplan et al., 2009). Residents that move into gentrifying neighbourhoods tend to exhibit common characteristics, such as a younger age, a higher education and income, and employment in more professional fields (Beauregard, 1986; Caulfield, 1994; Kaplan et al., 2009). With the arrival of these young urban residents, the rental values of the neighbourhood slowly increase, and soon lower income residents are driven out of the neighbourhood to look for more affordable living (Beauregard, 1986; Caulfield, 1994; Kaplan et al., 2009). By looking at the Canadian census and national household survey data, it is possible to get a view of how the neighbourhood's socio-economic 
characteristics have changed over many years. The information currently available includes the 2001, 2006, and 2011 census, as well as the 2011 national household survey. Unfortunately, at the completion of this thesis research much of the 2016 census data has yet to be organized and disseminated to the public. As a result, any demographic information that would indicate the gentrification in the 2016 census has not been included in this study. The census and national household survey information collected and analyzed for this study focus on Ward 18 Davenport, which contains the entirety of the Junction Triangle. Census information for the Junction Triangle neighbourhood by itself is not available, and in order to get the best idea of the changes occurring in this neighbourhood, the Ward 18 demographics were used.

Changes in age statistics can indicate gentrification, as areas that are experiencing the process tend to see increases in the younger population, and decreases in the older ones (Beauregard, 1986; Caulfield, 1994; Lees et al., 2008). The 2001 and 2006 census showed changes in the age demographics, as between the two census years the younger age groups experienced decreases while older ones had seen increases (Statistics Canada, 2001; Statistics Canada, 2006). This data would indicate that gentrification may not be occurring, as one would expect to see the opposite in a gentrifying neighbourhood. However, during the 2011 census, evidence of the effect gentrification has on age became clearer, as many younger age groups, such as the $25-34$ groups, began to grow, while many older age groups, such as the $75-79$ group, diminished (Statistics Canada, 2011a). As gentrification takes many years to change the demographics of the area, the changes in age could have just began to take place during the 2011 census.

The younger residents who move into gentrifying neighbourhoods also tend to have higher incomes, leading to a change in income levels within the area (Beauregard, 1986; 
Caulfield, 1994; Lees et al., 2008). When higher income families move into redeveloping neighbourhoods, housing sales and rental values tend to increase (Beauregard, 1986; Lees et al., 2008). This leads to lower income families departing for more affordable living, while higher income residents begin to move in (Beauregard, 1986; Lees et al., 2008). This movement of people leads to changes in the income levels of a neighbourhood. This change is seen within Ward 18, as between the three census years, the average annual household income increased by \$17,002 (Statistics Canada, 2001; Statistics Canada, 2006; Statistics Canada, 2011b). In 2001, the annual income was $\$ 50,390$ annually, in 2006 annual income grew to $\$ 55,317$, and in 2011 , annual income again increased to $\$ 67,392$ (Statistics Canada, 2001; Statistics Canada, 2006; Statistics Canada, 2011b). Although some of this change can be attributed to inflation, the census data shows that through the three census years, the most dominant income levels changed from the lower income population, to middle and upper income homes (Statistics Canada, 2001; Statistics Canada, 2006; Statistics Canada, 2011b). This would indicate that many higher income residents began to move into the area and residents began to earn more and move into higher income levels (Statistics Canada, 2001; Statistics Canada, 2006; Statistics Canada, 2011b).

The higher income residents that move into the area, also tend to be well educated and possess higher educational qualifications than the population that resided there previously (Beauregard, 1986; Caulfield, 1994; Lees et al., 2008). In 2001, 41.3\% of the population of Ward 18 did not have any form of certificate, degree or diploma, while $58.7 \%$ had received an education (Statistics Canada, 2001). In 2006, these numbers changed as the number of educated residents grew to $66.8 \%$ of the population, while those who did not receive an educational qualification decreased to $33.2 \%$ (Statistics Canada, 2006). By the 2011 census year, $74.2 \%$ of the population had received a certificate, degree or diploma, while 25.8\% did not (Statistics 
Canada, 2011b). Within these 10 years, post secondary education saw the largest increase in number, while trades certificates saw the largest decreases (Statistics Canada, 2011b).

Changes in education lead to changes in employment as well, as well-educated residents tend to be employed in more professional fields (Beauregard, 1986; Caulfield, 1994; Lees et al., 2008). Slowly, the area shifts away from industrial and trades employment, and fields, such as sales, business, health, and government, become more prominent (Beauregard, 1986; Caulfield, 1994; Lees et al., 2008). Through the 3 census years, there were noticeable decreases in the percentage of the labour force employed in primary industry, processing, manufacturing, trades and utilities (Statistics Canada, 2001; Statistics Canada, 2006; Statistics Canada, 2011b). As these fields of employment diminished, higher paying and more professional fields, such as health, government, education, began to experience growth (Statistics Canada, 2001; Statistics Canada, 2006; Statistics Canada, 2011b. The ward is slowly transforming in both economic and social characteristics, which can be attributed to the gentrification of the area. However, the process is not only visible through changes in demographics, but through transformations of the physical structure of the area as well.

The 2011 national household survey showed that approximately $61.5 \%$ of housing in Ward 18 dates back to before the 1960s, $17.3 \%$ between 1961 and 1980, 5.1\% between 1981 and 1990, 5.2\% between 1991 and 2000, and 10.9\% between 2001 to 2011 (Statistics Canada, 2011b). During the 2016 tree inventory, the types of housing and number of homes within the Junction Triangle study area were recorded, along observations of the improvements, or lack of, on these homes. The Junction Triangle study area is made up different forms of housing, including low rise apartments, row homes, stacked townhomes, and semi-detached homes. The most dominant forms of housing in the study area are semi-detached homes and stacked 
townhomes. Within the study area there are 448 semi-detached homes, and three sections of land where stacked townhomes have been constructed, with one more housing project soon to be underway.

Physical evidence of gentrification is seen in the Junction Triangle study area through the renovations of older structures and the creation of new housing stock. Housing renovations are one of the most visible evidences of gentrification, and in a gentrifying neighbourhood one can expect to see a large number of refurbished homes (Helms, 2003). One of the top priorities in gentrifying neighbourhoods is to maintain property value because homeowners who renovate their homes desire to garner profit and sell their home at a higher price (Ley, 1986; Wyly, \& Hammel, 1999; Lees et al., 2008). Depreciation in property value is heavily related to design, obsolescence and quality, as buildings whose issues are not repaired can begin to physically deteriorate (Baum, 1993; Wyly, \& Hammel, 1999; Glaeser \& Gyourko, 2005). The appearance of a building is integral in maintaining property value, as older and outdated designs can potentially lead to the depreciation of a home's value (Baum, 1993). Although many of the older structures in the study area have yet to be improved, a larger number of homes have had renovations conducted on them for the purposes of maintenance and appeal. Out of the 448 semidetached homes in the study area, 275, approximately $61 \%$, have had improvements made to them. Figure 4 shows examples of homes that have been renovated. These renovated homes do not exhibit the visible physical issues that older, deteriorating housing in the neighbourhood does. 

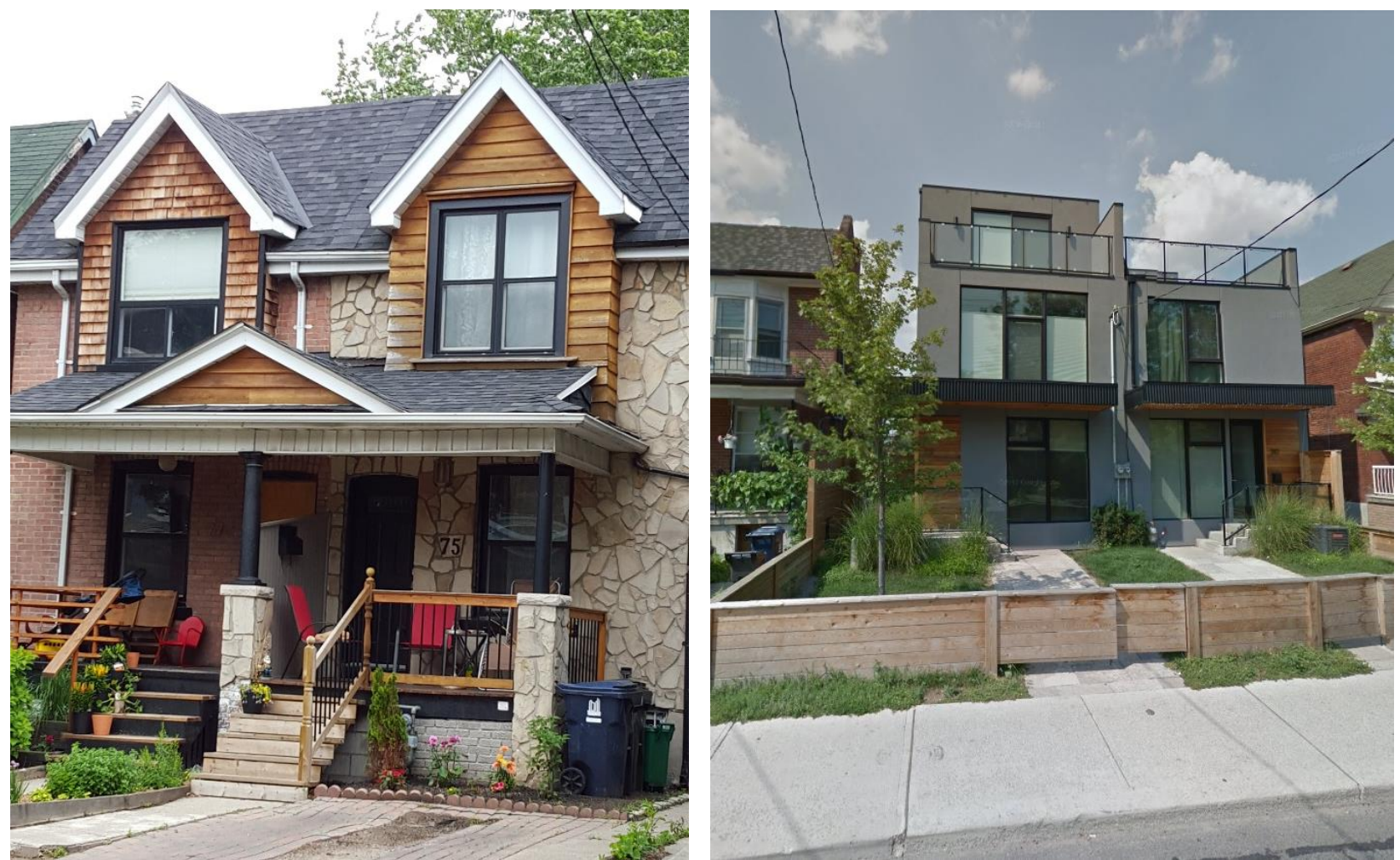

Figure 4: Improved homes in the Junction Triangle. These homes are two examples of many within the study area, and exhibit improvements such as reconstructed walls and windows, new paint, new fences and railings, improved stair cases, new trees and front garden, and new parking area.

Renovated homes are not the only physical evidence of gentrification, as the creation of new housing stock is also an indication of the process (Ley 1986; Smith, 1987; Kaplan et al., 2009). Newer housing stock improves the physical quality of a neighbourhood, which can attract wealthy residents (Beauregard, 1986; Helms, 2003; Lees et al., 2008). New housing stock can be built on vacant plots of land or by razing older structures to make way for these new ones (Kaplan et al., 2009). Within the study area, new housing projects have occurred in recent years, and more new projects are set to take place in the near future. The new forms of housing being built within the study area are stacked townhomes. The most recent housing project within the study area was in 2011 on a vacant plot of land along Wallace Avenue. Figure 5 shows historical satellite imagery taken from Google Earth showing the progression of the construction of these homes. The first image shows the empty plot of land along Wallace Avenue where the stacked 
townhomes would soon be constructed. The second image shows the finished townhomes, known as the Brownstones on Wallace, along Wallace Avenue and the newly created Elsie Lane.

The construction of the Brownstones on Wallace in 2011 is not the only housing project that has taken place within the study area. Gentrification in this area is continuing with another housing project soon to be underway. This new housing project, called Heritage Towns on the Trail, will create stacked townhomes on the empty plot of land along Ernest Avenue, as shown in Figure 6. This plot of land previously contained a scrap metal sales, processing and disposal business, called Solway Metals, which ended their business in 2012. New housing projects in this study area seem to be taking place on underutilized land and industrial sites, rather than tearing down structures to replace them, in order to create new and attractive homes for wealthy residents. Gentrification has been affecting this neighbourhood for many years, and its changes are clearly visible through the number of renovated homes and the creation of new housing stock. This area is still changing as more houses have yet to be renovated and new housing stock has yet to be built.
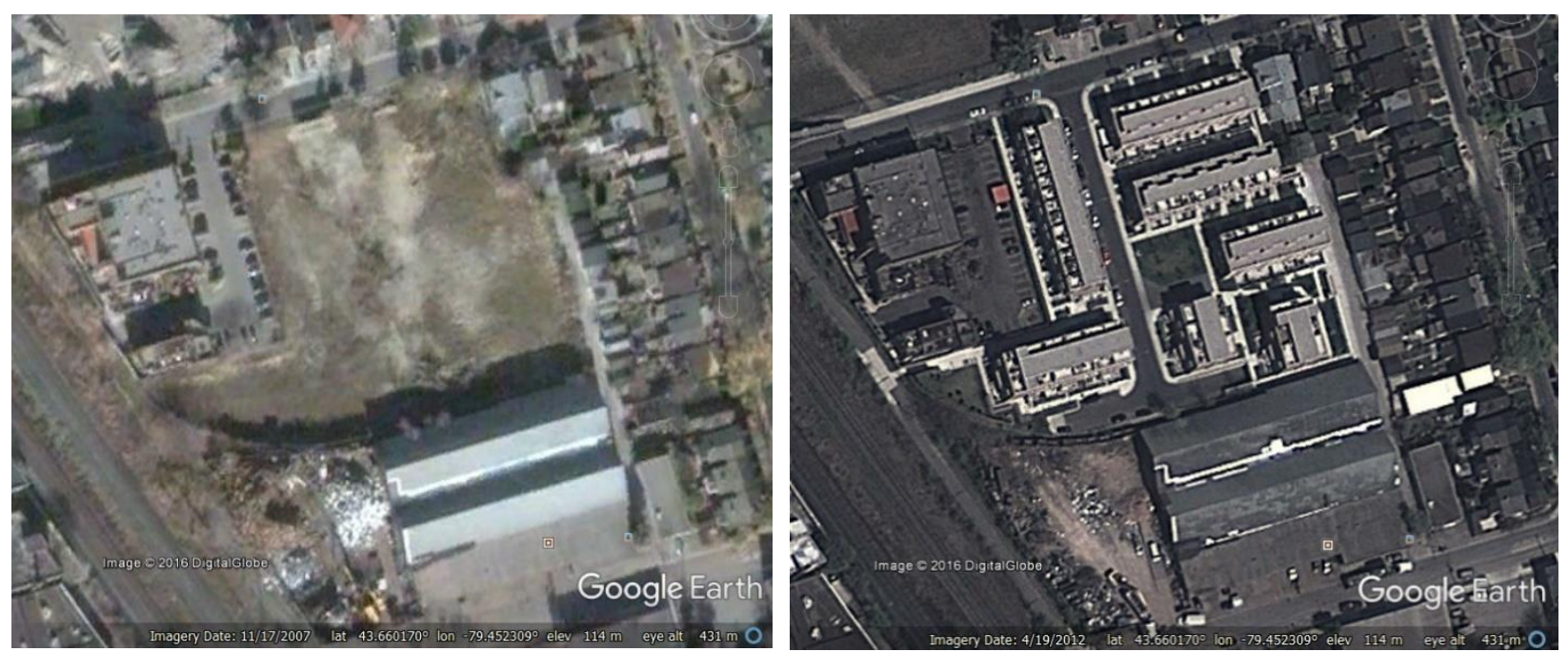

Figure 5: The construction of the Brownstones on Wallace in 2007 and 2009 (Google Earth, 2007; Google Earth 2012). 

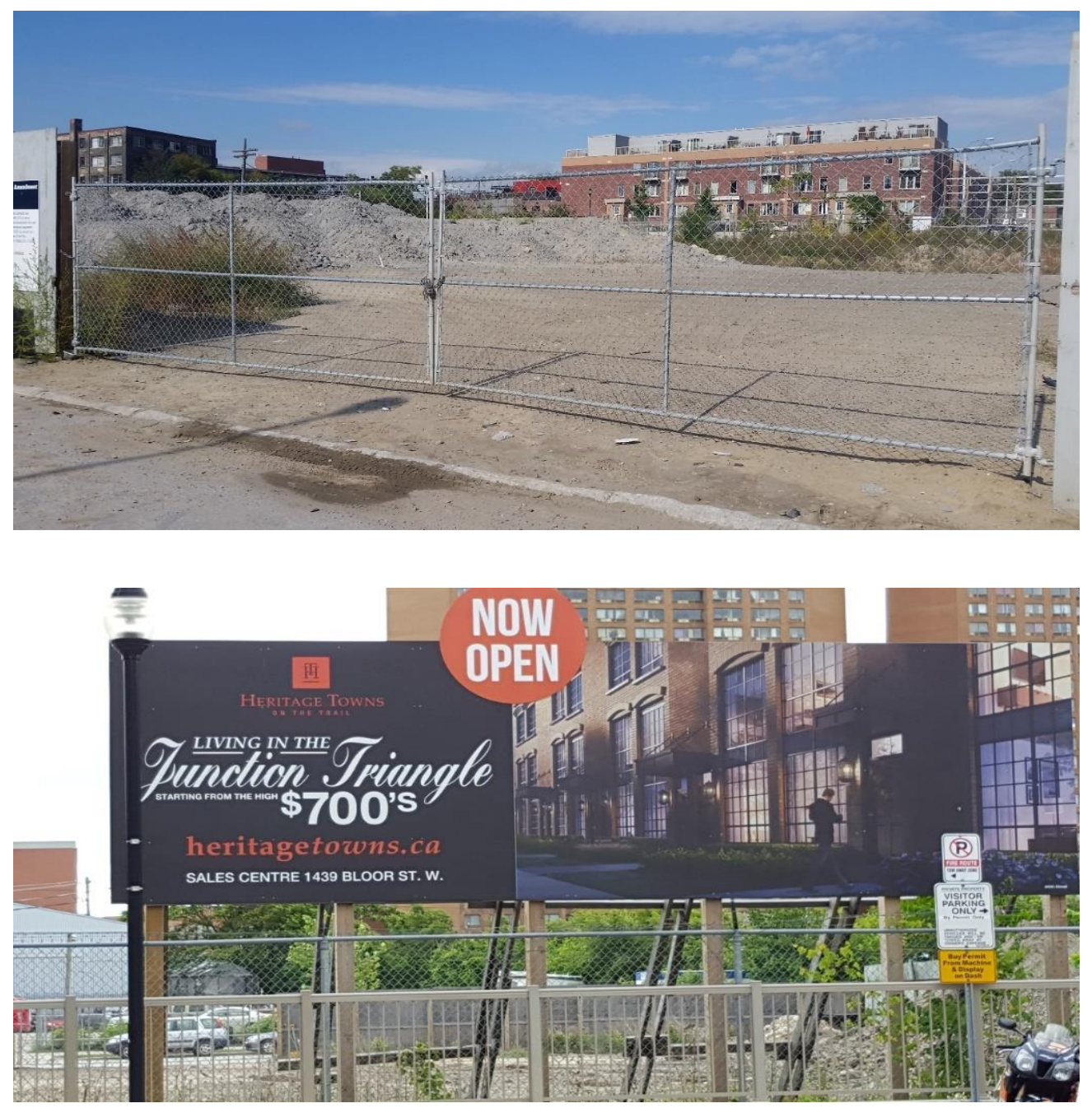

Figure 6: Heritage Towns on the Trail.

\subsubsection{Questionnaire Results}

Gentrification has clearly changed the physical structure, as well as the demographic characteristics, of the neighbourhood. However, the impact that these changes have on the residents of the neighbourhood are not yet understood. One of the main focuses of this thesis research is to investigate how the redevelopments within the study area are viewed by the residents. The method used to gain this insight was the utilization of a questionnaire. The hypothesis that is being tested is that residents who have moved into the area since 2007 view 
gentrification more positively than those who have moved into the area prior to that year. The questionnaire recorded information from residents nearly nine years after 2007, and many changes have occurred in that time. It is important to understand and analyze the opinions of those who have lived in the study area for a long period of time, and have experienced the changes that gentrification elicits, as well as those who are newer to the area. The data gathered during the questionnaire was used to gain an understanding of the residents' thoughts and underlying reasoning to their aversion to, or support of, gentrification and its corresponding changes. The full results of the questionnaire are available in Appendix 3.4.

For this research, 150 questionnaires were distributed, and 53 responses were collected, giving a response rate of approximately $35 \%$. Although this response rate is lower than what has been projected in literature, the responses still give insight into the thoughts and actions of residents regarding gentrification and forestry. To get a better understanding of whether the sample population is representative of the neighbourhood, the demographic characteristics collected in the questionnaire must be compared to the demographic characteristics of the Junction Triangle as a whole. Unfortunately, census data for the Junction Triangle is not available, and the questionnaire did not collect much demographic information. In order to make the best comparison with the data available, the demographic characteristics collected in the questionnaire, age and home ownership, have been compared to the census and national household survey data from 2011 of Ward 18. Although the census data is from many years prior to the completion of the questionnaire, this was the most recent data available at the completion of this research. 
Table 1 and 2 show the age and home ownership characteristics of both the respondents to the questionnaire and Ward 18. What this shows is that, based on the data from the questionnaire, census, and national household survey, that the sample of 53 residents from the

study area is not quite representative of the Ward 18

Table 1: Age characteristics population. Although the age and home ownership characteristics of the sample population and Ward 18 population are not comparable, other demographic information such as income, education, ethnicity,

\begin{tabular}{|l|l|l|}
\hline Age groups & $\begin{array}{l}\text { Questionnaire } \\
\text { respondents }\end{array}$ & Ward 18 \\
\hline $\mathbf{2 1}-\mathbf{3 0}$ & $17 \%$ & $19 \%$ \\
\hline $\mathbf{3 1}-\mathbf{4 0}$ & $40 \%$ & $20 \%$ \\
\hline $\mathbf{4 1 - 5 0}$ & $11 \%$ & $15 \%$ \\
\hline $\mathbf{5 1}-\mathbf{6 0}$ & $28 \%$ & $12 \%$ \\
\hline $\mathbf{6 1 +}$ & $4 \%$ & $17 \%$ \\
\hline
\end{tabular}
employment, shelter costs, and others, were not collected by the questionnaire. This does not necessarily mean that the sample of 53 residents is not representative of the area as Table 2: Homeownership characteristics.

\begin{tabular}{|l|l|l|}
\hline $\begin{array}{l}\text { Home } \\
\text { Ownership }\end{array}$ & $\begin{array}{l}\text { Questionnaire } \\
\text { respondents }\end{array}$ & $\begin{array}{l}\text { Ward } \\
\mathbf{1 8}\end{array}$ \\
\hline Own & $81 \%$ & $46 \%$ \\
\hline Rent & $19 \%$ & $54 \%$ \\
\hline
\end{tabular}
a whole, as there is a lack of information to make a good comparison between the two populations. Unfortunately, this is a limitation of this thesis research.

Out of the 53 respondents to the questionnaire, 35 , which is approximately $66 \%$, stated that they moved into the neighbourhood prior to 2007, while 18 respondents, approximately $34 \%$, moved into the neighbourhood after 2007. Table 3 shows the ages of the respondents in both groups. The questionnaire asked residents how they felt about the redevelopments currently taking place within their neighbourhood. The answer choices were rated on a Likert scale, where 1 and 2 represented strongly like and somewhat like Table 3: Ages of respondents moving in prior to and after 2007

\begin{tabular}{|l|l|l|}
\hline Age Groups & $\begin{array}{l}\text { Respondents } \\
\text { prior to 2007 }\end{array}$ & $\begin{array}{l}\text { Respondents } \\
\text { after 2007 }\end{array}$ \\
\hline $\mathbf{2 1}-\mathbf{3 0}$ & $1(3 \%)$ & $8(44 \%)$ \\
\hline $\mathbf{3 1}-\mathbf{4 0}$ & $11(31 \%)$ & $10(56 \%)$ \\
\hline $\mathbf{4 1}-\mathbf{5 0}$ & $6(17 \%)$ & 0 \\
\hline $\mathbf{5 1}-\mathbf{6 0}$ & $15(43 \%)$ & 0 \\
\hline $\mathbf{6 1 +}$ & $2(6 \%)$ & 0 \\
\hline Total & 35 & 18 \\
\hline
\end{tabular}
respectively, 3 represented a neutral answer, and 4 and 5 represented somewhat dislike and 
strongly dislike respectively. It is possible that the answers to this question may have been influenced by age, as many of the individuals who moved in after

2007 are younger. However, it is unclear if these differences are attributed to their age or late arrival. As Table 4 shows, 37 of the 53 respondents, approximately $70 \%$, stated that they disliked the

Table 4: Respondents who liked, disliked, or stayed neutral towards gentrification

\begin{tabular}{|l|l|}
\hline Response & $\begin{array}{l}\text { Number of } \\
\text { Respondents }\end{array}$ \\
\hline Like & 6 \\
\hline Dislike & 37 \\
\hline Neutral & 10 \\
\hline
\end{tabular}
redevelopments and renovations occurring in their neighbourhood, while 6 respondents, or $11 \%$, stated that they liked the changes, and 10 respondents, approximately $19 \%$, remained neutral. A Chi-square analysis was done to determine if there were significantly more respondents showing a negative opinion of gentrification (reporting Likert scale values of 4 and 5) versus a positive opinion (reporting Likert scale values of 1 and 2). The expectation is that there would be an equal number (i.e. of 43 respondents claiming either to like or dislike gentrification, there would be, on average, 21.5 in each category). The results of this analysis gave a Chi-square value of 22.3 , and a $p$ value less than 0.001 . Since the test has given a $p$ value far lower than the 0.05 alpha level, the analysis shows there is a statistical difference between the two groups.

As shown in Table 5, all of the respondents who stated that they liked gentrification and its changes had moved into the neighbourhood after 2007. These six residents that stated that they liked the redevelopments and renovations in the neighbourhood because these changes Table 5: Respondents who liked and disliked gentrification.

\begin{tabular}{|l|l|l|}
\hline $\begin{array}{l}\text { Time moved into } \\
\text { the neighbourhood }\end{array}$ & $\begin{array}{l}\text { Dislike } \\
\text { gentrification }\end{array}$ & $\begin{array}{l}\text { Like } \\
\text { gentrification }\end{array}$ \\
\hline Prior to 2007 & 26 & 0 \\
\hline After 2007 & 11 & 6 \\
\hline
\end{tabular}
increased the general attractiveness of the area. They further stated that renovations on the older housing created more appealing homes in the neighbourhood. All six of these respondents stated that they currently lived in a home that had been renovated. Five of these individuals owned the homes, while one respondent stated that they rented the home. 
The data in Table 5 shows that the majority of respondents who moved in both prior to and after 2007 disliked the process of gentrification and its associated changes occurring in the neighbourhood. All respondents who moved in prior to 2007 answered that they disliked the changes. For respondents who moved in after 2007, nearly twice as many answered that they disliked the redevelopments than liked. These respondents cited a variety of reasons for their aversion to the redeveloping neighbourhood, the most common being that construction caused increased traffic in the area, and that the construction was unattractive. Other responses included that the construction was too noisy, as well as fears that new lofts and condominium units would decrease interest in buying homes. Five respondents further stated that along with these nuisances, they also did not like the new families or individuals that have moved into the neighbourhood, although why this is the case was not identified. The responses from all the individuals that disliked the redeveloping neighbourhood seemed to focus more on the irritations associated with renovations, such as the increased congestion and noise level. Only a small number of responses focused on the social or demographic changes that have been associated with gentrification, such as wealthier citizens moving into the neighbourhood, or increased rental values (Beauregard, 1986; Kaplan et al., 2009; Lees et al., 2008). The hypothesis that was tested using the questionnaire was that residents who moved in after 2007 view the process of gentrification more positively than those who have moved into the neighbourhood prior to 2007. The results of the questionnaire show that, although the majority of residents in both groups view the process negatively, there are more residents in the after 2007 group who like the redevelopments, than there are in the prior to 2007 group. Although this sample of 53 residents does not represent the population of the study area as a whole, the questionnaire has given some insight into how residents feel about the redevelopments occurring in their neighbourhood. 


\subsection{Tree Species}

Gentrification is an ongoing process that has been thoroughly researched. However, the effects that the process may have on the environment, especially on trees, have not yet been well investigated. A step towards a better understanding of urban forestry is by studying the species of trees in a neighbourhood that is currently redeveloping. The changing urban landscape is stressful, and can potentially threaten many species of trees, while others may survive and thrive (Sun, 1992). The diversity of tree species is integral to the resiliency of a city's urban forest, as new environmental and biological challenges can threaten many species of trees (Endress, 1990). In neighbourhoods that are undergoing gentrification, maintaining the value of the property is one of the top priorities (Ley, 1986; Wyly, \& Hammel, 1999; Lees et al., 2008). Research has shown that increasing the number and species of trees around a home leads to increases in property value as well (Anderson \& Cordell, 1988; Dwyer et al., 1992). This relationship between trees and property value indicates that gentrifying neighbourhoods would experience an increase in number and species of trees, as studies like Heynen (2006) and Merse et al. (2008) have demonstrated. However, research conducted by Steenberg et al. (2017) suggest that increased building renovations would result in higher tree mortality, and a lower number of trees overall.

This thesis research investigated tree species and number to test the second hypothesis, that gentrification is attributed to a greater number of trees and tree species in the study area. Both the City of Toronto and residents of the Junction Triangle have participated in the gentrification of the study area, through the renewal and renovation of infrastructure and housing. The tree inventory conducted in 2007 recorded a total of 802 trees and 54 species within the Junction Triangle study area. The updated inventory in 2016, which is available in 
Appendix 1, had recorded 1001 trees and 59 species, which is 199 more trees and 7 more species that what was recorded during the 2007 inventory. Figure 7 shows an updated map of the Junction Triangle study area, depicting three different coloured dots. The blue dots on the map represent newly growing trees in the study area, which were recorded during the updated inventory in 2016. The yellow dots represent trees that were present during the 2007 inventory but were cut down and did not appear in the 2016 tree inventory. Last, the red dots represent trees that were recorded during the 2007 inventory, and still appeared in the 2016 inventory.

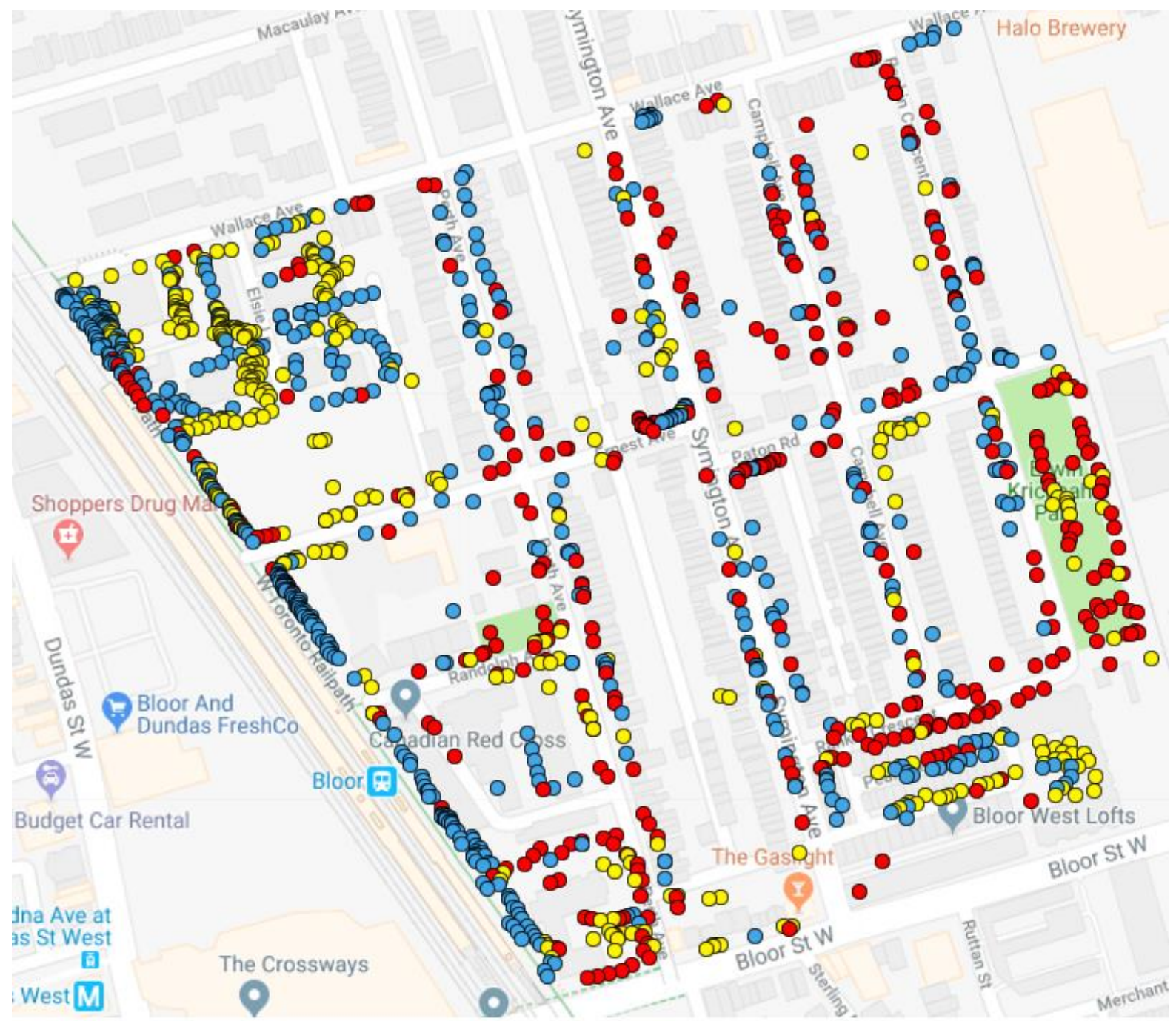

Figure 7: Updated map of the Junction Triangle study area. The blue dots on the map represent newly growing trees that were recorded during the 2016 inventory. The yellow dots represent trees that were cut down between the two inventory years, and the red dots represent trees were recorded in 2007 and were still there during the 2016 inventory. 
Of these 1001 trees recorded during the 2016 inventory of the study area, 627 trees were planted in front of homes, 52 along boulevards, 57 in parks, and 265 trees along the West Toronto Railpath. 604 of the total number of trees were newly planted, specifically 343 in front of homes, 27 along boulevard strips, and 234 along the West Toronto Railpath. Between the two inventory years, 59 species were recorded. 12 species are new to the study area, while 7 species were removed since the previous inventory.

These new species include the big leaf maple, common pawpaw, Japanese cherry, Japanese katsura, Kentucky coffee tree, Kentucky yellowwood, London plane tree, northern catalpa, Ohio buckeye, American sweet gum, tulip tree, and white spruce. Eleven of these tree species are included in the City of Toronto's tree planting protocol to increase the city's tree canopy to $40 \%$ total cover (City of Toronto, no date). The City of Toronto is committed to promoting the growth and diversity of the urban forest and has created a list of 36 tree species that are recommended to be planted on boulevards and public road allowances. These recommended trees are trees that are well suited for urban environments (City of Toronto, no date). The City of Toronto's Parks, Forestry, and Recreation has been contacted, and representative of this department explained that the recommended trees that Toronto has been planting has changed over time. Over the last few decades, the City has been planting trees and adding trees to the recommended tree list based on which species were more successful in the urban environment, and which were not. The Norway maple is an example of a species that the city had been planting but has recognized that this species is invasive and can outcompete native plants, and now is no longer actively being planted by the City. The recommended list has grown over time, and now includes trees that were previously not considered, such as the dawn 
redwood, white spruce, and white pine. Unfortunately, the older lists and information detailing these changes is unavailable online.

While new tree species have appeared in the area, several tree species have been lost entirely. There are seven species of trees that no longer appear in the study area between the two inventory years, including the balsam poplar, common lilac, European mountain ash, hackberry, Russian olive, saucer magnolia, and white oak. Over time, tree species between the 2007 and 2016 inventories have changed from more invasive and non-native species, to species native to southern Ontario and more suited for urban environments (City of Toronto, no date). These changes help to make the neighbourhood a more productive part of the city's urban forest. These changes are easily noticeable for trees located on both public land and in front of housing.

\subsubsection{Tree Species on Public Land}

A part of the gentrification of this study area is the renewal of public infrastructure, such as streets and railways. Trees are an essential component of a city's infrastructure, and a large part of the revitalisation of public land includes the addition and removal of trees (Merse et al., 2008; Wolch et al., 2014). This can have both negative and positive effects on urban forestry. The removal of trees, without proper replacement, would diminish the urban forest and reduce the canopy cover of the area, thereby limiting the social, economic, and environmental benefits associated with forestry (Endress, 1990; Sun, 1992; Steenberg et al., 2017). The addition of trees, as well as species suitable for urban environments, would help sustain the urban forest and bring more benefits to larger number of residents (Nowak et al, 1996; Nowak et al., 2010). 
In this thesis research, trees on public land have been categorized into three main sections: trees along boulevards, trees located in parks, and trees planted along the West Toronto Railpath. The changes in tree species and number are noticeable along boulevards as between the two inventory years, 28 trees and five new species were newly planted, 26 trees and three species were removed, and 25 trees and nine species remained. In Table 6, information regarding the species of trees, their nativity, and if they are city-recommended is depicted. Along with this, the number of new trees, trees lost, and trees remaining between the two inventory years is displayed to give a better idea of the churn occurring along boulevards.

Table 6: Trees along boulevards (Sibley, 2009).

\begin{tabular}{|c|c|c|c|c|c|}
\hline $\begin{array}{l}\text { Species of trees along } \\
\text { boulevards }\end{array}$ & Nativity & $\begin{array}{l}\text { City } \\
\text { recommended? }\end{array}$ & $\begin{array}{l}\text { Number of new } \\
\text { trees }\end{array}$ & $\begin{array}{l}\text { Number of } \\
\text { trees lost }\end{array}$ & $\begin{array}{l}\text { Number of trees } \\
\text { remaining } \\
\text { between } 2007 \\
\text { and } 2016\end{array}$ \\
\hline Chinese elm & $\begin{array}{l}\text { Non-native } \\
\text { (Invasive) }\end{array}$ & No & - & - & 1 \\
\hline Choke Cherry & Native & No & - & 3 & - \\
\hline European beech & Non-native & Yes & 6 & - & - \\
\hline European mountain ash & $\begin{array}{l}\text { Non-native } \\
\text { (Invasive) }\end{array}$ & No & - & 2 & - \\
\hline Ginkgo & Non-native & Yes & 3 & - & - \\
\hline Green ash & Native & No & - & 3 & 5 \\
\hline Honey locust & Non-native & Yes & 1 & - & 2 \\
\hline Kentucky coffee tree & Native & Yes & 3 & - & - \\
\hline Little leaf linden & Non-native & Yes & 5 & - & - \\
\hline Manitoba maple & Native (Invasive) & No & - & 3 & 7 \\
\hline Norway maple & $\begin{array}{l}\text { Non-native } \\
\text { (Invasive) }\end{array}$ & No & - & 5 & 5 \\
\hline Ohio buckeye & Native & Yes & 1 & - & - \\
\hline Red oak & Native & Yes & - & - & 2 \\
\hline Redbud & Native & No & - & - & 1 \\
\hline Siberian elm & $\begin{array}{l}\text { Non-native } \\
\text { (Invasive) }\end{array}$ & No & - & - & 1 \\
\hline Silver maple & Native & No & - & - & 1 \\
\hline Tree of heaven & $\begin{array}{l}\text { Non-native } \\
\text { (Invasive) }\end{array}$ & No & 9 & 9 & - \\
\hline White oak & Native & Yes & - & 1 & - \\
\hline
\end{tabular}


The tree species that have remained between the two inventory years consist of five species native to southern Ontario and four non-native species (Sibley, 2009). Of the non-native species, the honey locust is the only one that is not invasive. Furthermore, this tree is listed on the city's recommended tree list as it a resilient tree that can thrive in urban conditions (City of Toronto, no date; Sibley 2009). Of the native trees, the Manitoba maple is the only species that is considered invasive. Invasive species are dangerous for the urban forest as they can inhibit the growth of native vegetation around them, while spreading throughout the urban forest rapidly (Sibley, 2009). Both the non-native and native trees that remain along boulevards are important to the urban canopy of this neighbourhood. These trees have been growing for many years, developing bigger and denser crowns and contributing to a larger urban canopy (Sibley, 2009).

Between 2007 and 2016, a total of 26 trees have been lost, 10 of which were native trees, while 16 were non-native invasive trees. Of the native species that have seen a loss, the one white oak and three choke cherry trees died or were removed, which completely takes the presence of these species out of boulevards. The non-native species that have declined in number are all invasive species, and 16 total invasive trees have been lost. The European mountain ash is the only invasive species to be completely removed from boulevards. Nine tree of heaven trees were lost along boulevards, but the same number grew back within the two inventory years. Losing invasive species may diminish the urban tree canopy but may also be beneficial for the future of the urban forest, as the removal or death of these trees would allow native species to grow. However, the loss of native trees along boulevards diminishes the urban forest, as these trees naturally grow in southern Ontario and are an important part of the forest and canopy. Although not numerous, these trees are valuable species that can provide a variety of benefits for residents, wildlife, and the environment (Nowak et al., 2010). 
In order to maintain and create a healthier and more diverse urban forest, trees that have been removed need to be replaced. Along boulevards, the city has been planting valuable tree species that not only add beauty to the landscape but are more suitable for urban environments (City of Toronto, no date). These species include the European beech, ginkgo, Kentucky coffee tree, little leaf linden, and Ohio buckeye, totalling an increase of 18 trees. Along with these species, one new honey locust and nine new tree of heaven trees have been growing as well. As the tree of heaven is an invasive species, it is possible that seeds from this species have been transported by wildlife and wind, allowing new trees to grow rapidly (Ding et al. 2006). The other six species are all city recommended trees and have been planted because of the benefits and beauty that these trees provide, as well as their natural resistances to urban stressors, such as poor soil conditions, drought, pollution, heat, and pests (City of Toronto, no date; Sibley, 2009). Although these trees are well suited for urban environments, they are new trees and are not very large. Due to their size, they cannot contribute greatly to the overall canopy cover of the neighbourhood. However, over time these trees will mature and become a more productive part of the city's urban forest.

Despite the city's commitment to sustaining and expanding the urban forest, the second section of public land that this thesis research has focused on, parks, have not experienced as much positive change as boulevards have. There are two parks within the study area, Erwin Krickhahn Park, and Perth Avenue Parkette. Parks have the highest diversity of species among the three areas of public land within the study area. The tree inventory in 2007 recorded 18 species and 73 trees, while the updated inventory in 2016 showed that two species and 16 trees 
were lost, with no new trees or species being added. Table 7 shows the tree and species changes that have occurred in parks.

Table 7: Trees located in parks (Sibley, 2009).

\begin{tabular}{|c|c|c|c|c|c|}
\hline $\begin{array}{l}\text { Species of trees } \\
\text { in parks }\end{array}$ & Nativity & $\begin{array}{l}\text { City } \\
\text { recommended? }\end{array}$ & Number of new trees & $\begin{array}{l}\text { Number of trees } \\
\text { lost }\end{array}$ & $\begin{array}{l}\text { Number of trees } \\
\text { remaining between } \\
2007 \text { and } 2016\end{array}$ \\
\hline Black locust & $\begin{array}{l}\text { Non-native } \\
\text { (Invasive) }\end{array}$ & Yes & - & 1 & 4 \\
\hline Black maple & Native & Yes & - & - & 7 \\
\hline Chinese elm & $\begin{array}{l}\text { Non-native } \\
\text { (Invasive) }\end{array}$ & No & - & - & 1 \\
\hline Choke cherry & Native & No & - & - & 3 \\
\hline Douglas fir & Non-native & No & - & - & 4 \\
\hline Freeman maple & $\begin{array}{l}\text { Hybrid of native } \\
\text { maple species }\end{array}$ & Yes & - & 1 & 3 \\
\hline Green ash & Native & No & - & 1 & 3 \\
\hline $\begin{array}{l}\text { Manitoba } \\
\text { maple }\end{array}$ & Native (Invasive) & No & - & - & 4 \\
\hline Red oak & Native & Yes & - & - & 1 \\
\hline Redbud & Native & No & - & 6 & 7 \\
\hline Scotch elm & $\begin{array}{l}\text { Non-native } \\
\text { (Invasive) }\end{array}$ & No & - & - & 1 \\
\hline Scots pine & $\begin{array}{l}\text { Non-native } \\
\text { (Invasive) }\end{array}$ & No & - & - & 1 \\
\hline Siberian elm & $\begin{array}{l}\text { Non-native } \\
\text { (Invasive) }\end{array}$ & No & - & - & 1 \\
\hline Silver maple & Native & Yes & - & 1 & 2 \\
\hline Tamarack & Native & No & - & - & 7 \\
\hline $\begin{array}{l}\text { Trembling } \\
\text { aspen }\end{array}$ & Native & No & - & 4 & 8 \\
\hline Tree of heaven & $\begin{array}{l}\text { Non-native } \\
\text { (Invasive) }\end{array}$ & No & - & 1 & - \\
\hline White oak & Native & Yes & - & 1 & - \\
\hline
\end{tabular}

Out of the species of park trees that are remaining, six are non-native to southern Ontario, and 10 are native, totalling 57 trees (Sibley, 2009). The native species that remain in parks outnumber the non-native species, as 45 of the 57 remaining trees are native to southern Ontario. However, the Manitoba maple is a species that is native, but is considered an invasive species in southern Ontario, due its aggressive nature and its ability to survive in a variety of urban and 
natural conditions (Sibley, 2009). There are 12 non-native trees remaining. Of these species, the only non-invasive tree is the Douglas fir. The black locust is species that is city recommended, but exhibits invasive characteristics (Sibley, 2009). This species is hardy and able to adapt to different soil and weather conditions, which is why it may be a city recommended tree (Sibley, 2009; Warne, 2016). However, it is an aggressive species that forms colonies and shades out native plants (Warne, 2016). All of the trees remaining in parks are in poor condition, which is discussed in more detail in section 5.3. Due to the declining health of these trees they may not be as much of a productive part of the urban forest or be able to provide the economic, social, and environmental benefits, that healthier trees can. It is possible that these remaining trees are adventive trees, but it is also possible they have been planted by the city, as the species of the trees that the city plants and the recommended tree list have changed over time.

Between the two inventory years, the parks in the study area have changed mainly through the loss of trees, as no new species or trees have grown or planted. A total of 16 trees have been lost between 2007 and 2016, two of which were non-native, while 14 were native species. The black locust, of which one tree was lost, and tree of heaven, which also lost one tree, were the only two non-native trees to decline in number. The loss of this sole tree has removed the presence of the tree of heaven from parks within the study area. The other 14 trees are all native species. Of these native species, the one white oak was removed and no longer appears in parks within the study area. This species, along with the Freeman maple, and silver maple, are all city recommended trees and should ideally be planted more often. The two species that experienced the largest decreases in number are the redbud and trembling aspen species. Six redbud trees and four trembling aspen trees were removed from parks. 
While the City of Toronto's policy is to build up the number of trees, the urban canopy is being diminished by their loss. Parks like Erwin Krickhahn Park and Perth Avenue Parkette are meant for enjoyment of peace and serenity, as they do not have sports equipment, such as baseball diamonds and basketball courts. The addition of trees would add to the beauty and tranquillity of the urban environment, while the removal of trees would take away from it (Schroeder, 1989; Wilson et al., 2013). In order for parks to be a productive part of the city's urban forest, these trees should be replaced with more species more suitable for the urban environment, as they have been along boulevards. Along with these two parks, the West Toronto Railpath is another area of public land that has experienced a lack of upkeep and maintenance. This pathway is not very well maintained as plants here are growing wildly, as shown in Figure

8.
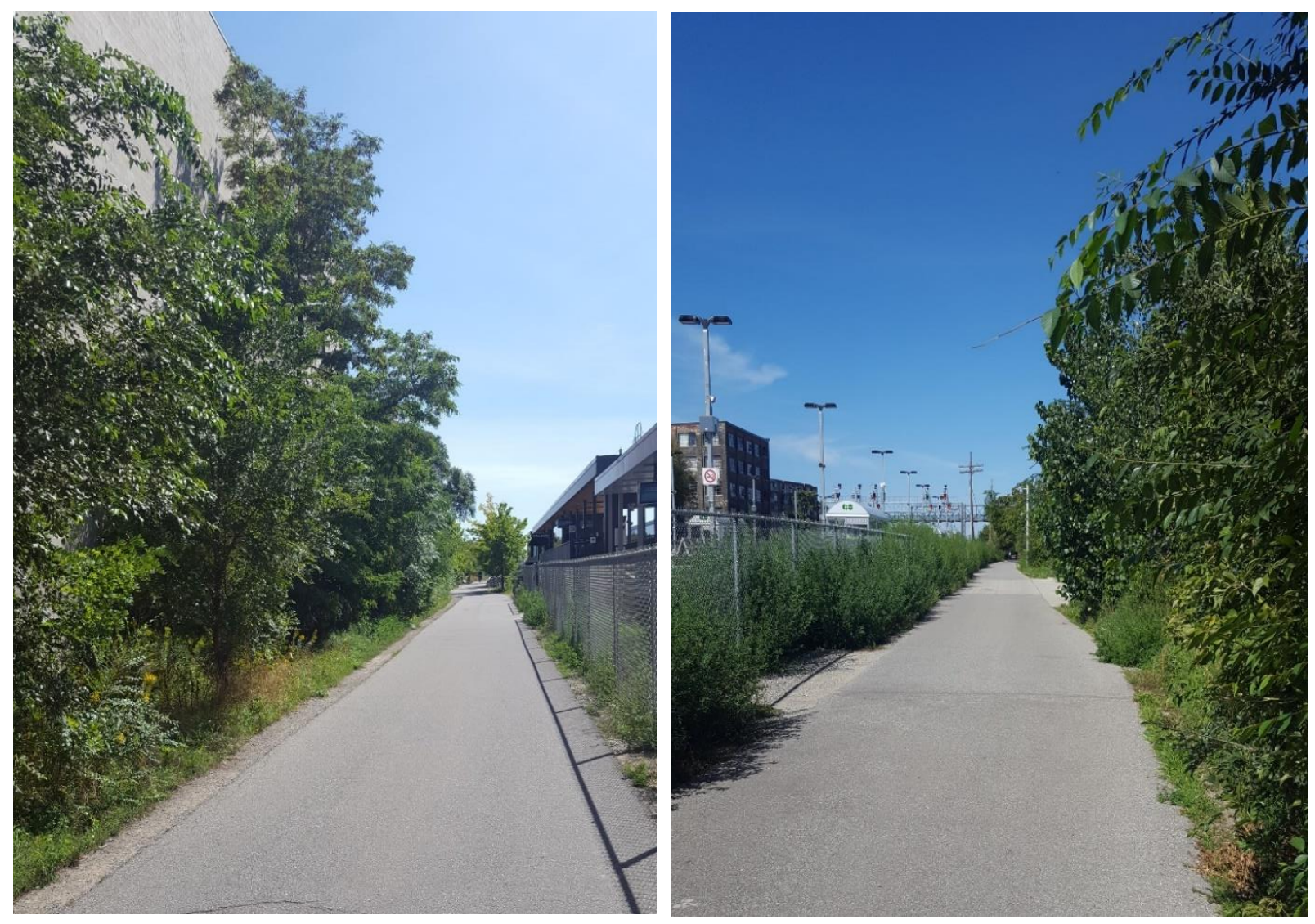

Figure 8: The West Toronto Railpath. 
The West Toronto Railpath has the least diversity of species in public land in the study area but has the largest number of trees and has seen a great amount of change. During the 2007 tree inventory, seven different species and 71 trees were recorded along the West Toronto Railpath. During the updated inventory in 2016, these numbers grew to 10 species and a total of 265 trees, 234 of which were newly growing in the area. Table 8 shows the species and number of trees in both inventory years.

Table 8: Trees along the West Toronto Railpath (Sibley, 2009).

\begin{tabular}{|c|c|c|c|c|c|}
\hline $\begin{array}{l}\text { Species along the West } \\
\text { Toronto Railpath }\end{array}$ & Nativity & City recommended? & $\begin{array}{l}\text { Number of new } \\
\text { trees }\end{array}$ & $\begin{array}{l}\text { Number of } \\
\text { trees lost }\end{array}$ & $\begin{array}{l}\text { Number of } \\
\text { trees remaining } \\
\text { between } 2007 \\
\text { and } 2016\end{array}$ \\
\hline American elm & Native & Yes & 20 & - & - \\
\hline Black locust & $\begin{array}{l}\text { Non-native } \\
\text { (Invasive) }\end{array}$ & Yes & 12 & - & - \\
\hline Chinese elm & $\begin{array}{l}\text { Non-native } \\
\text { (Invasive) }\end{array}$ & No & 52 & - & - \\
\hline Freeman maple & $\begin{array}{l}\text { Hybrid of native } \\
\text { maple species }\end{array}$ & Yes & 13 & - & - \\
\hline Green ash & Native & No & - & 3 & - \\
\hline Honey Locust & Non-native & Yes & - & 1 & - \\
\hline Manitoba maple & Native (Invasive) & No & 11 & 19 & 13 \\
\hline Norway maple & $\begin{array}{l}\text { Non-native } \\
\text { (Invasive) }\end{array}$ & No & - & 1 & - \\
\hline Paper birch & Native & No & 10 & 3 & 4 \\
\hline Siberian elm & $\begin{array}{l}\text { Non-native } \\
\text { (Invasive) }\end{array}$ & No & 19 & 1 & 2 \\
\hline Tree of heaven & $\begin{array}{l}\text { Non-native } \\
\text { (Invasive) }\end{array}$ & No & 84 & 12 & 12 \\
\hline Trembling aspen & Native & No & 6 & - & - \\
\hline White mulberry & $\begin{array}{l}\text { Non-native } \\
\text { (Invasive) }\end{array}$ & No & 7 & - & - \\
\hline
\end{tabular}

Since its construction, both the express line and the railpath have undergone continuous redevelopment (City of Toronto 2013; Metrolinx, 2015). The improvements made to the transit system has contributed to the gentrification of the neighbourhood. Although housing renovation is the most visible evidence of gentrification, reinvestment into urban infrastructure influences 
the gentrification of a neighbourhood as well (Lees et al., 2008; Merse et al., 2008; Kaplan et al., 2009). In order for this area to be a more productive part of the urban forest, invasive trees need to be removed and replaced with more appropriate species, as has happened along boulevards.

Of the tree species that have experienced decreases, three were native, while four were non-native. 40 total trees had died or were removed. The loss of the green ash, honey locust, and paper birch diminishes the urban forest as the green ash and paper birch are native trees, and the honey locust is a non-native species but is listed on the city's recommended tree list. The green ash species were likely removed due to the presence of the emerald ash borer pest, as all green ash trees in this neighbourhood have been marked for the presence, or lack of presence, of the pest. However, there are not many trees of this species, as seven green ash trees have been removed. The non-native and invasive species that have been cut down are much more numerous than the native species, as 33 non-native and invasive trees were lost. The Manitoba maple, of which 19 trees were removed, has experienced the greatest loss. One Norway maple tree along the West Toronto Railpath was lost, and its removal takes the presence of the species out of area. The removal of all these trees diminishes the urban canopy, but by replacing them with more appropriate species, the city is ensuring the growth of the urban forest and canopy in the future.

The trees that have been experiencing growth along the West Toronto Railpath are made up of five species native to southern Ontario, of which 60 trees were new, and five non-native species, of which 174 trees were new. Of the native species, the American elm and Freeman maple are the only two city recommended species. 20 new American elm trees and 13 new Freeman maple trees were recorded during the 2016 inventory. The American elm is a species that is native to southern Ontario but is a species that is susceptible to Dutch elm disease (Sibley, 2009; City of Toronto, no date). Due to this, the City of Toronto have been planting a cultivar of 
the American elm, as it is resistant to Dutch elm disease (City of Toronto, no date). The Freeman maple is a recommended species that does not grow naturally, as it is a hybrid of the red maple and silver maple, which are both species native to southern Ontario. This species of tree is also very hardy and tolerant of urban conditions, making it ideal to be planted in the city (City of Toronto, no date). The trembling aspen is also a species that has been newly introduced to the West Toronto Railpath. Although not a city recommended tree, six new trembling aspen trees were growing in the area. Of these five native species, the Manitoba maple, of which 11 trees were newly growing, is the only invasive species.

The five non-native species are all invasive trees. Although a city recommended tree, the black locust has an invasive nature, and has grown by 12 trees along the West Toronto Railpath (Sibley, 2009; Warne, 2016). The largest increases in number have been seen by the Chinese elm, and tree of heaven, growing by 52 trees and 84 trees respectively. All of these invasive species are commonly found along roadsides, waste places, disturbed woods, and other areas not commonly maintained, which makes the West Toronto Railpath a place where they would thrive (Sibley, 2009). Many of the new tree species along the Railpath are adventive trees and seem to be not controlled by the city. In order for this trail to be a more productive part of the urban forest, it needs to be better maintained, through the removal of invasive trees and plants as well as the addition of more suitable species. The city has begun to do this, as the addition of the American elm and Freeman maple species are beneficial for this area, but further maintenance is required. 


\subsubsection{Tree Species in front of Homes}

In the years between the two tree inventories, the largest and most noticeable changes to urban tree species in the study area have occurred with trees planted in front of housing. During the 2007 tree inventory, 48 species and 597 trees were planted in front of housing, whereas in 2016, 54 species and 634 trees were recorded, 344 of which were new trees. Table 9 shows the changes in number and species in front of homes.

Table 9: Species and number of trees in front of homes (Sibley, 2009).

\begin{tabular}{|c|c|c|c|c|c|}
\hline $\begin{array}{l}\text { Species in front of } \\
\text { homes: }\end{array}$ & Nativity & $\begin{array}{l}\text { City } \\
\text { recommended? }\end{array}$ & $\begin{array}{l}\text { Number of new } \\
\text { trees }\end{array}$ & $\begin{array}{l}\text { Number of trees } \\
\text { lost }\end{array}$ & $\begin{array}{l}\text { Number of trees } \\
\text { remaining } \\
\text { between } 2007 \text { and } \\
2016\end{array}$ \\
\hline American elm & Native & Yes & 3 & - & 6 \\
\hline Apricot tree & Non-native & No & - & - & 2 \\
\hline Austrian pine & Non-native & No & 1 & 5 & 6 \\
\hline Balsam fir & Native & No & - & - & 1 \\
\hline Balsam poplar & Native & No & - & 1 & - \\
\hline Basswood & Native & No & 2 & 6 & 2 \\
\hline Big leaf maple & Non-native & No & 1 & - & - \\
\hline Black maple & Native & Yes & 2 & - & 1 \\
\hline Blue spruce & Non-native & No & 4 & 3 & 6 \\
\hline Callery pear tree & Non-native & No & 3 & 3 & 8 \\
\hline Canada plum tree & Native & No & - & 1 & 1 \\
\hline Cherry plum tree & Non-native & No & - & 12 & 27 \\
\hline Chinese elm & $\begin{array}{l}\text { Non-native } \\
\text { (Invasive) }\end{array}$ & No & 1 & 9 & 1 \\
\hline Choke cherry & Native & No & 2 & 3 & 6 \\
\hline Common apple & Non-native & No & - & 4 & 2 \\
\hline Common lilac & Non-native & No & - & 7 & - \\
\hline Common pawpaw & Native & No & 1 & - & - \\
\hline Corkscrew willow & Non-native & No & - & - & 1 \\
\hline Douglas fir & Non-native & No & 3 & 1 & 3 \\
\hline Eastern white cedar & Native & No & 106 & 11 & 40 \\
\hline Eastern white pine & Native & No & 2 & 1 & - \\
\hline English oak & Non-native & Yes & 11 & - & 8 \\
\hline European beech & Non-native & Yes & - & 1 & - \\
\hline European mountain ash & $\begin{array}{l}\text { Non-native } \\
\text { (Invasive) }\end{array}$ & No & - & 3 & - \\
\hline
\end{tabular}




\begin{tabular}{|c|c|c|c|c|c|}
\hline Freeman maple & $\begin{array}{l}\text { Hybrid of native } \\
\text { maples species }\end{array}$ & Yes & 4 & 11 & 1 \\
\hline Gingko & Non-native & Yes & 12 & 4 & 1 \\
\hline Green ash & Native & No & - & 29 & 14 \\
\hline Hackberry & Native & Yes & - & 2 & - \\
\hline Honey locust & Non-native & Yes & 19 & 4 & 13 \\
\hline Japanese cherry & Non-native & No & 1 & - & - \\
\hline Japanese katsura & Non-native & Yes & 4 & - & - \\
\hline Japanese maple & Non-native & No & 7 & 3 & 4 \\
\hline Kentucky coffee tree & Native & Yes & 5 & - & - \\
\hline Kentucky yellowwood & Non-native & Yes & 4 & - & - \\
\hline Little leaf linden & Non-native & Yes & 27 & 10 & 9 \\
\hline London plane tree & Non-native & Yes & 8 & - & - \\
\hline Manitoba maple & Native (Invasive) & No & 1 & 56 & 20 \\
\hline Northern catalpa & Non-native & Yes & 1 & - & \\
\hline Norway maple & $\begin{array}{l}\text { Non-native } \\
\text { (Invasive) }\end{array}$ & No & 12 & 10 & 61 \\
\hline Norway spruce & $\begin{array}{l}\text { Non-native } \\
\text { (Invasive) }\end{array}$ & No & 15 & 3 & 1 \\
\hline Ohio buckeye & Native & Yes & 3 & - & - \\
\hline Paper birch & Native & No & 2 & 1 & 5 \\
\hline Peach tree & Non-native & No & - & - & 2 \\
\hline Red maple & Native & Yes & 3 & 1 & - \\
\hline Red mulberry & Native & No & - & - & 2 \\
\hline Red oak & Native & Yes & 4 & 8 & 2 \\
\hline Red spruce & Native & No & 5 & - & 2 \\
\hline Redbud & Native & No & - & - & 3 \\
\hline Russian olive & $\begin{array}{l}\text { Non-native } \\
\text { (Invasive) }\end{array}$ & No & - & 1 & - \\
\hline Saucer magnolia & Non-native & No & - & 2 & - \\
\hline Siberian elm & $\begin{array}{l}\text { Non-native } \\
\text { (Invasive) }\end{array}$ & No & 1 & 9 & 10 \\
\hline Silver maple & Native & Yes & 6 & 4 & 6 \\
\hline Sugar maple & Native & Yes & 13 & - & 2 \\
\hline Swedish white beam & Non-native & No & - & - & 1 \\
\hline Sweet gum & Non-native & Yes & 1 & - & - \\
\hline Tree of heaven & $\begin{array}{l}\text { Non-native } \\
\text { (Invasive) }\end{array}$ & No & 8 & 74 & 7 \\
\hline Tulip tree & Non-native & Yes & 3 & - & - \\
\hline Weeping cypress & Non-native & No & 2 & - & 1 \\
\hline White mulberry & $\begin{array}{l}\text { Non-native } \\
\text { (Invasive) }\end{array}$ & No & 9 & 3 & 2 \\
\hline White spruce & Native & Yes & 19 & - & - \\
\hline
\end{tabular}


Between the two inventory years, 290 trees and 39 species remained. These 39 species are made up of 17 native species, of which 114 trees remain, and 22 non-native species, of which 176 trees remain. Six of the 17 native species are city recommended species, including the American elm, black maple, Freeman maple, red oak, silver maple, and sugar maple. Of the 114 native trees, 18 are city recommended trees. Of the non-native species remaining, the English oak, ginkgo, honey locust, and little leaf linden are on the city's recommended list. Of the 176 non-native trees, 31 are city recommended trees. Invasive species still have a strong presence in the study area, as 102 total trees remained between 2007 and 2016. Regardless of the nativity of the remaining trees, they all contribute to the urban canopy of the neighbourhood.

Between the 2007 and 2016 inventories, 35 different species experienced diminishing numbers. A total of 306 trees were lost. Of these species, 14 were native to southern Ontario, while 21 are non-native. 135 native trees and 171 non-native trees had died or were removed between the two inventory years. Thirteen of the 14 native species removed are valuable species, the other being the Manitoba maple, an invasive species in southern Ontario. Of these trees, the hackberry and balsam poplar have been completely removed from in front of homes in the study area. The hackberry is a species listed on the city's tree planting brochure and should be planted more often. Like this species, the Freeman maple, of which 11 trees were lost, and the red oak, of which 8 trees were lost, are listed on the City of Toronto's tree planting brochure as well. Although these species have not been completely removed, the loss of these recommended trees diminishes the urban forest and canopy of the neighbourhood. The native species that have experienced the greatest loss are the green ash and Manitoba maple species. 29 green ash trees and 56 Manitoba maple trees were lost between 2007 and 2016. The green ash trees were removed likely due to the presence of the emerald ash borer. 
Between the two inventories, more non-native species have been removed than native species. 171 total non-native trees were lost. Non-native species that have been completely removed include the common lilac, European beech, European mountain ash, Russian olive, and saucer magnolia. Of these five species, the European beech is a city recommended tree. The little leaf linden, of which 10 trees were lost, is another species on the city's list that has experienced a decline in number. Both the European beech and the little leaf linden should ideally be planted more often in order to contribute to the urban forest. While these trees are recommended trees, the European mountain ash and Russian olive trees are invasive species, losing three and one tree respectively, completely removing these species from the study area. Of the 171 non-native trees that have been removed, 109 are invasive species. The Siberian elm, Norway maple, Norway spruce, and tree of heaven are all trees that exhibit invasive nature and have experienced a decline in number. The tree of heaven species, of which 74 trees have died or been removed, has seen the greatest decline in number.

While many trees and species have been lost, many more have been added in front of homes in the study area, as 43 species have experienced increases in number, totalling a growth of 341 trees. Of these species, 18 are native, of which 183 trees are new, while 25 are non-native, of which 158 trees are new. Four native species and 28 trees have been newly introduced to homes in the study area, including one common pawpaw tree, five Kentucky coffee trees, three Ohio buckeye trees, and 19 white spruce trees. The Kentucky coffee tree, Ohio buckeye, and white spruce are all species listed on the city's tree planting brochure. Along with these three species, the American elm, black maple, Freeman maple, red maple, red oak, silver maple, and sugar maple are native recommended species that have experienced an increase in numbers as well. Of the 183 new native trees in front of homes, 62 are city recommended trees. The species 
that has experienced the greatest growth of all the new native trees, is not a species recommended by the City of Toronto. The eastern white cedar, of which 106 trees are new, has seen a large increase between the two inventory years. This species is commonly cultivated as an ornamental and hedge tree (Sibley, 2009). In this study area, many residents have been planting this species of tree around their homes to obtain this hedge affect.

24 non-native species, of which 158 trees are new, have seen growth in front of homes in the study area. Of these species, six are invasive. There are 46 non-native invasive trees appearing in front of homes. Six species that are non-native and do not exhibit invasive characteristics have been newly added to the area, including the one big leaf maple tree, one Japanese cherry tree, four Japanese katsura trees, one northern catalpa tree, one sweet gum tree, and three tulip trees. The Japanese katsura, northern catalpa, sweet gum, and tulip tree are all city recommended trees. Along with these four species, six other recommended species have experienced increased numbers as well, including, the English oak, ginkgo, honey locust, Kentucky yellowwood, little leaf linden, and London plane tree. Of the 160 new non-native trees, 90 are city recommended non-native species. These trees are all ornamental street trees that do well in under conditions (City of Toronto, no date; Sibley, 2009). The non-native trees that have experienced the greatest increases in number are the honey locust, of which 19 are new, and little leaf linden, of which 27 trees are new. These trees are non-native species, but are not aggressive, while other species that have appeared in the study area, such as the 12 Norway maple trees and 15 Norway spruce trees, exhibit invasive traits.

Between the two inventory years, there has been a great amount of change in the number and species of trees in front of homes. The trees that remain between 2007 and 2016 are important as they have been growing for a number of years and contribute to the urban canopy of 
the neighbourhood. However, these trees consist of mostly invasive trees. These species are hazardous to native trees and the future of the urban forest. Although most of these trees exhibit aggressive nature, they are an important part of the canopy of the neighbourhood. In between the two inventory years, both native and non-native species have been removed. This diminishes the urban canopy of the neighbourhood, but ensures the longevity of trees in the area, as the majority of these trees are invasive species, such as the Manitoba maple, Norway maple, and tree of heaven. However, the loss of these invasive trees allows species native to southern Ontario and non-native species that do not exhibit aggressive characteristics, to thrive and survive. In order for trees around homes to have a more positive affect on the urban forest, these lost trees need to be replaced. The value of the urban forest is being taken into consideration as more trees and species have been newly planted in front of homes than have been removed. The new trees and species being planted are made up mostly of native and city-recommended trees, although some invasive species have begun to grow as well. These new native and recommended trees are beneficial for the urban forest as many trees naturally grow in southern Ontario, while others are hardy species capable of thriving under urban stressors (City of Toronto, no date; Sibley 2009).

These results are similar to the results of Heynen (2006) and Merse et al. (2008), as these studies have found that gentrifying neighbourhoods tend to see increases in the number and species of trees. However, research conducted by Steenberg et al. (2017), suggest that the opposite is true, where areas that have more housing renovations and new buildings experience losses in trees. Within the study area of this neighbourhood, more trees have been added than removed between the two inventory years. Although, as Steenberg et al. (2017) suggests, the urban canopy has been diminished by the loss of trees, and these new trees are not large and cannot contribute to the canopy of the neighbourhood. However, these trees will mature and 
contribute more to the canopy over the coming decades. These trees are also well suited for urban environments and will be a more productive part of the urban forest, able to offer more benefits to residents for a longer period of time, than the invasive species that once grew in front of homes.

The new trees that have been planted are a combination of adventive trees, city planted, and resident planted. Many of the new species are not city recommended trees and likely were planted by residents, due to their uniqueness and appeal. Adding these attractive trees to the front of a home not only adds beauty and serenity to the environment but helps increase the value of the property as well (Anderson \& Cordell, 1988; Dwyer et al., 1992; Escobedo et al., 2014). This relationship between trees and property value provides an incentive for homeowners to invest in urban trees (Escobedo et al., 2014). In a gentrifying neighbourhood, homeowners try to maximize the profits of homes by increasing the appeal of the home, usually through renovations (Beauregard, 1986; Baum, 1993; Wilson et al, 2013). In this study area, the housing stock is gentrifying, and as this process continues, both the city and its residents are participating in changing the structure of trees through planting a wide variety of tree species. The number, quality, and rarity of trees in front of homes typically attracts attention and tends to increase the value of the home (Anderson \& Cordell, 1988; Dwyer et al., 1992; Escobedo et al., 2014).

The construction of Brownstones on Wallace, shown in Figure 5 in section 5.1, shows how gentrification has changed the structure of trees in the study area. This housing project consists of the construction of stacked townhomes and new streets along Wallace Avenue. These new buildings and infrastructure have changed the neighbourhood in a very noticeable way, as many trees and species were removed and replaced. During the 2007 inventory, the plot of land along Wallace Avenue, contained 17 different species and a total of 146 trees. The 2016 
inventory recorded 8 species, and a total of 40 trees. Table 10 shows the species and number of trees for both inventory years.

Table 10: Changes in species and number due to construction of stacked townhomes (Sibley, 2009).

\begin{tabular}{|c|c|c|c|c|c|}
\hline Species & Nativity & $\begin{array}{l}\text { City } \\
\text { recommended? }\end{array}$ & $\begin{array}{l}\text { Number of new } \\
\text { trees }\end{array}$ & $\begin{array}{l}\text { Number of trees } \\
\text { lost }\end{array}$ & $\begin{array}{l}\text { Number of trees } \\
\text { remaining }\end{array}$ \\
\hline American elm & Native & Yes & 2 & - & - \\
\hline Blue spruce & Non-native & No & - & 2 & - \\
\hline $\begin{array}{l}\text { Cherry plum } \\
\text { tree }\end{array}$ & Non-native & No & - & 2 & - \\
\hline Chinese elm & $\begin{array}{l}\text { Non-native } \\
\text { (Invasive }\end{array}$ & No & - & 4 & - \\
\hline Common apple & Non-native & No & - & 1 & - \\
\hline Common lilac & Non-native & No & - & 1 & - \\
\hline $\begin{array}{l}\text { Eastern white } \\
\text { cedar }\end{array}$ & Native & No & - & 4 & - \\
\hline $\begin{array}{l}\text { Eastern white } \\
\text { pine }\end{array}$ & Native & No & - & 1 & - \\
\hline Freeman maple & $\begin{array}{l}\text { Hybrid of native } \\
\text { maple species }\end{array}$ & Yes & 3 & 1 & - \\
\hline Ginkgo & Non-native & Yes & 5 & 1 & - \\
\hline Green ash & Native & No & & 4 & \\
\hline Japanese cherry & Non-native & No & 1 & - & - \\
\hline $\begin{array}{l}\text { Kentucky coffee } \\
\text { tree }\end{array}$ & Native & Yes & 1 & - & - \\
\hline Little leaf linden & Non-native & Yes & 18 & 3 & - \\
\hline Manitoba maple & Native (Invasive) & No & - & 44 & - \\
\hline Norway maple & $\begin{array}{l}\text { Non-native } \\
\text { (Invasive) }\end{array}$ & No & - & 4 & - \\
\hline Red oak & Native & Yes & 1 & - & - \\
\hline Russian olive & $\begin{array}{l}\text { Non-native } \\
\text { (Invasive) }\end{array}$ & No & - & 1 & - \\
\hline Siberian elm & $\begin{array}{l}\text { Non-native } \\
\text { (Invasive) }\end{array}$ & No & - & 8 & - \\
\hline Tree of heaven & $\begin{array}{l}\text { Non-native } \\
\text { (Invasive) }\end{array}$ & No & - & 63 & - \\
\hline White mulberry & $\begin{array}{l}\text { Non-native } \\
\text { (Invasive) }\end{array}$ & No & - & 2 & - \\
\hline White spruce & Native & Yes & 9 & - & - \\
\hline
\end{tabular}

Between the two inventory years, the construction of the stacked townhomes removed all species of trees growing in the area. Of the 17 species growing on the plot of land, 5 were native to southern Ontario, while 12 were non-native species. A total of 54 native trees and 92 non- 
native trees were removed. The native species include the eastern white cedar, eastern white pine, the Freeman maple, green ash, and Manitoba maple. The Manitoba maple species is invasive and has experienced the greatest decline in number of the native trees, as 44 Manitoba maple trees were lost. Of the 12 non-native species that have been lost in this area, six are invasive species. These invasive species have experienced a total loss of 82 of the 92 non-native trees. The invasive species that has seen the greatest decline in number is the tree of heaven, as 63 tree of heaven trees have been removed. The construction of this new housing has led to a large loss of trees and species, which diminishes the urban canopy of this neighbourhood. This outcome is much like what Steenberg et al. (2017) has argued, where concentrated changes in housing stock lead to substantial losses of trees.

However, after the construction of the stacked townhomes, many new trees and species were planted. A total of eight species and 40 trees were planted around the townhomes. Of these eight species, five were native species, and three were non-native. 16 new trees were native, while 24 were non-native trees. These native species include the American elm, Freeman maple, Kentucky coffee tree, red oak, and white spruce. All of these trees are city recommended trees, as they are well suited for urban environments (City of Toronto, no date; Sibley, 2009). Along with these native species, two of the three non-native species also on the city's tree planting brochure. These species, include the ginkgo and little leaf linden, which have grown by five trees, and 18 trees respectively. The sole species that is not city recommended that has been planted in front of the stacked townhomes is the Japanese cherry species, which has only one tree growing in the area.

The construction of the Brownstones on Wallace is a part of the gentrification of this neighbourhood. The creation of this housing stock has had both negative and positive effects on 
the urban forest. A large number of trees have been removed, and this diminishes the urban canopy of the neighbourhood. However, many of these trees were invasive species, and by removing and replacing them with more suitable and native trees, it helps native species survive and thrive. After the creation of these stacked townhomes, native species and species recommended by the city have been planted outside of these homes. Although there have been less trees added, these trees are better suited for urban environments and will eventually contribute to the urban canopy of the neighbourhood.

Along with the creation of stacked townhomes, renovating semi-detached homes can change the structure of trees as well. Housing renovation is the most visible evidence of gentrification, and homes in the study area have experienced a large amount of renovation (Helms, 2003). Residents living in stacked townhomes do not have the freedom to conduct renovations and plant or remove trees in front of their home, as the building and land outside is mutually shared (Madi et al., 2015). However, owners of semi-detached homes have more autonomy to preform renovations and add or remove trees. In the Junction Triangle neighbourhood, the city owns the property in front of a home and are able to add trees or cut them down without permission from the homeowner. However, residents of semi-detached homes can request to plant or take away trees with permissions and permits obtained from the City of Toronto. During the tree inventory, information on the renovations conducted on semidetached homes were collected and based on visual evidences of renovations outlined by research such as Hammel and Wyly (1996) and Baum (1993), homes were categorized as improved or unimproved. In 2007, 35 different species and 162 trees were recorded in front of improved homes, while the 2016 inventory recorded 45 species and 310 trees. Table 11 shows the changes in species and number for improved homes. 
Table 11: Species and number of trees in front of improved homes (Sibley, 2009).

\begin{tabular}{|c|c|c|c|c|c|}
\hline $\begin{array}{l}\text { Species in front of improved } \\
\text { homes }\end{array}$ & Nativity & $\begin{array}{l}\text { City } \\
\text { recommended? }\end{array}$ & $\begin{array}{l}\text { Number of new } \\
\text { trees }\end{array}$ & $\begin{array}{l}\text { Number of trees } \\
\text { lost }\end{array}$ & $\begin{array}{l}\text { Number of trees } \\
\text { remaining between } \\
2007 \text { and } 2016\end{array}$ \\
\hline American elm & Native & Yes & 1 & - & 5 \\
\hline Apricot tree & Non-native & No & - & - & 2 \\
\hline Austrian pine & Non-native & No & 1 & - & 2 \\
\hline Basswood & Native & No & 2 & 1 & 2 \\
\hline Big leaf maple & Non-native & No & 1 & - & - \\
\hline Black maple & Native & Yes & 2 & - & - \\
\hline Blue spruce & Non-native & No & 4 & 1 & 2 \\
\hline Callery pear tree & Non-native & No & 3 & 2 & 4 \\
\hline Canada plum tree & Native & No & - & - & 1 \\
\hline Cherry plum tree & Non-native & No & & 1 & 10 \\
\hline Chinese elm & $\begin{array}{l}\text { Non-native } \\
\text { (Invasive) }\end{array}$ & No & 1 & 1 & 1 \\
\hline Choke cherry & Native & No & - & 2 & 5 \\
\hline Common apple & Non-native & No & - & - & 1 \\
\hline Common pawpaw & Native & No & 1 & - & - \\
\hline Common lilac & Non-native & No & - & 1 & - \\
\hline Douglas fir & Non-native & No & - & 1 & - \\
\hline Eastern white cedar & Native & No & 86 & 1 & 28 \\
\hline Eastern white pine & Native & No & 2 & - & \\
\hline English Oak & Non-native & Yes & - & - & 1 \\
\hline European beech & Non-native & Yes & 1 & - & - \\
\hline European mountain ash & $\begin{array}{l}\text { Non-native } \\
\text { (Invasive) }\end{array}$ & & - & 1 & - \\
\hline Freeman maple & $\begin{array}{l}\text { Hybrid of native } \\
\text { maple species }\end{array}$ & Yes & 1 & 1 & 1 \\
\hline Ginkgo & Non-native & Yes & 4 & - & 1 \\
\hline Green ash & Native & No & - & 3 & 4 \\
\hline Hackberry & Native & Yes & - & 2 & - \\
\hline Honey locust & Non-native & Yes & 5 & 1 & 8 \\
\hline Japanese katsura & Non-native & Yes & 4 & - & - \\
\hline Japanese maple & Non-native & No & 7 & - & 2 \\
\hline Kentucky coffee tree & Native & Yes & 2 & - & - \\
\hline Kentucky yellowwood & Non-native & Yes & 1 & - & - \\
\hline Little leaf linden & Non-native & Yes & 2 & - & 3 \\
\hline London plane tree & Non-native & Yes & 3 & - & - \\
\hline Manitoba maple & Native (Invasive) & No & - & - & 2 \\
\hline Northern catalpa & Non-native & Yes & 1 & - & - \\
\hline Norway maple & $\begin{array}{l}\text { Non-native } \\
\text { (Invasive) }\end{array}$ & No & - & 2 & 27 \\
\hline
\end{tabular}




\begin{tabular}{|c|c|c|c|c|c|}
\hline Norway spruce & $\begin{array}{l}\text { Non-native } \\
\text { (Invasive) }\end{array}$ & No & 8 & - & - \\
\hline Ohio buckeye & Native & Yes & 4 & - & - \\
\hline Paper birch & Native & No & 1 & - & 2 \\
\hline Red oak & Native & Yes & 3 & - & - \\
\hline Red mulberry & Native & No & - & - & 1 \\
\hline Red spruce & Native & No & - & - & 1 \\
\hline Redbud & Native & No & 2 & - & 3 \\
\hline Siberian elm & $\begin{array}{l}\text { Non-native } \\
\text { (Invasive) }\end{array}$ & No & - & 1 & 1 \\
\hline Silver maple & Native & Yes & 5 & 3 & 3 \\
\hline Sugar maple & Native & Yes & 1 & - & 2 \\
\hline Tree of heaven & $\begin{array}{l}\text { Non-native } \\
\text { (Invasive) }\end{array}$ & No & - & 2 & 7 \\
\hline Tulip tree & Non-native & Yes & 2 & - & - \\
\hline Weeping cypress & Non-native & No & 2 & - & 1 \\
\hline White mulberry & $\begin{array}{l}\text { Non-native } \\
\text { (Invasive) }\end{array}$ & No & 3 & 1 & 1 \\
\hline White spruce & Native & Yes & 10 & - & - \\
\hline
\end{tabular}

In between the two inventory years, 19 species of trees experienced a decline in number. 12 of these species were non-native, while seven species were native. 13 native trees and 15 nonnative trees were removed. Between the two inventory years, non-native and native trees have lost nearly an equal number of trees. Like the other areas of land in the study area, invasive species have seen the largest decreases, as one European mountain ash tree, two Norway maple trees, one Siberian elm tree, two tree of heaven trees, and one white mulberry have died or been removed.

While 28 trees have been completely removed from in front of improved homes, 176 new trees have been planted. 123 native trees and 53 non-native trees have been newly planted. Of these native and non-native species, a total of 52 trees were city recommended trees. Although this is a large increase in the number of trees well suited for urban environments, species that are not listed on the city's tree planting brochure have seen the largest increases, as 124 non- 
recommended trees are new. The species that has seen the largest growth was the eastern white cedar, of which 86 trees are newly planted. Between the two inventory years, invasive and nonnative species has seen a decline in number, while native trees and species listed on the city's recommended tree list have seen large increases in front of improved homes. The land in front of these homes are owned by the city, and as numerous trees and species that have been added are city recommended trees, this suggests that the city is actively trying to add trees to this neighbourhood. While city recommended species have seen a larger growth, numerous nonrecommended trees have increased in number as well. Although the front yard of a home is owned by the city, it seems that many homeowners have been planting trees outside of their home as well. These species are attractive and appealing, and have been planted due to their varying colours, leaves, flowers, fruit, and size. Trees help increase the attractiveness of the urban landscape, and as residents add trees to the outside of their homes, it increases the incentive for other residents to do the same (Endress, 1990; Heynen, 2006). In gentrifying neighbourhoods, planting trees contributes to an increase in the value of the property (Anderson \& Cordell, 1988; Baum, 1993; Lees et al., 2008). A larger number and variety of species is seen in these gentrifying neighbourhoods, as trees are positively correlated with housing value and resale value (Anderson \& Cordell, 1988; Heynen, 2006; Merse et al. 2008; Escobedo et al., 2014).

In comparison to these gentrified homes, are homes that have not had renovations conducted on them. The 2007 inventory recorded 25 species and 67 trees, while the 2016 inventory recorded 27 species and 56 trees. Table 12 shows the change in species and number in front of unimproved homes 
Table 12: Species and number of trees in front of unimproved homes (Sibley, 2009).

\begin{tabular}{|c|c|c|c|c|c|}
\hline $\begin{array}{l}\text { New trees in front of } \\
\text { non-renovated homes: }\end{array}$ & Nativity & $\begin{array}{l}\text { City } \\
\text { recommended? }\end{array}$ & $\begin{array}{l}\text { Number of new } \\
\text { trees }\end{array}$ & $\begin{array}{l}\text { Number of trees } \\
\text { lost }\end{array}$ & $\begin{array}{l}\text { Number of trees } \\
\text { still there between } \\
2007 \text { and } 2016\end{array}$ \\
\hline American elm & Native & Yes & - & - & 1 \\
\hline Balsam fir & Native & No & & - & 1 \\
\hline Balsam Poplar & Native & No & - & 1 & - \\
\hline Basswood & Native & No & - & 1 & - \\
\hline Black maple & Native & Yes & - & - & 1 \\
\hline Canada plum & Native & No & - & 1 & - \\
\hline Cherry plum & Non-native & No & - & 2 & 1 \\
\hline Choke cherry & Native & No & - & - & 1 \\
\hline Common apple & Non-native & No & - & 3 & 1 \\
\hline Common lilac & Non-native & No & - & 5 & - \\
\hline Douglas fir & Non-native & No & - & - & 1 \\
\hline Eastern white cedar & Native & No & 2 & 3 & 5 \\
\hline Freeman maple & $\begin{array}{l}\text { Hybrid of native } \\
\text { maple species }\end{array}$ & Yes & - & 2 & - \\
\hline Green ash & Native & No & - & - & 1 \\
\hline Ginkgo & Non-native & Yes & 1 & - & - \\
\hline Honey Locust & Non-native & Yes & - & - & 2 \\
\hline Kentucky coffee tree & Native & Yes & 1 & - & - \\
\hline Little leaf linden & Non-native & Yes & 1 & 2 & 1 \\
\hline Manitoba maple & Native (Invasive) & No & - & 2 & 1 \\
\hline Norway maple & $\begin{array}{l}\text { Non-native } \\
\text { (Invasive) }\end{array}$ & No & 3 & 2 & 11 \\
\hline Norway spruce & $\begin{array}{l}\text { Non-native } \\
\text { (Invasive) }\end{array}$ & No & 2 & - & 1 \\
\hline Paper birch & Native & No & 1 & - & - \\
\hline Peach tree & Non-native & No & - & - & 2 \\
\hline Red maple & Native & Yes & 2 & 1 & - \\
\hline Red mulberry & Native & No & - & - & 1 \\
\hline Redbud & Native & No & 1 & - & - \\
\hline Red oak & Native & Yes & - & 1 & 1 \\
\hline Red spruce & Native & No & - & - & 1 \\
\hline Siberian elm & $\begin{array}{l}\text { Non-native } \\
\text { (Invasive) }\end{array}$ & No & - & - & 2 \\
\hline Tree of Heaven & $\begin{array}{l}\text { Non-native } \\
\text { (Invasive) }\end{array}$ & No & 2 & 5 & - \\
\hline Tulip tree & Non-native & Yes & 1 & - & - \\
\hline White mulberry & $\begin{array}{l}\text { Non-native } \\
\text { (Invasive) }\end{array}$ & No & 3 & - & - \\
\hline
\end{tabular}


Eight native species have experienced a loss, where 12 trees have died or been removed, while six non-native species have seen a loss, totalling 19 trees. Of the native trees, the Freeman maple, red maple, and red oak are the city recommended trees that have been diminished, losing four trees total. Two Manitoba maple trees, which are native invasive species, have been removed. The other native species that have seen diminishing numbers are the balsam poplar, basswood, Canada plum, and eastern white cedar. The six non-native species that have experienced losses include, the cherry plum, common apple, common lilac, little leaf linden, Norway maple, and tree of heaven. Of these species, the little leaf linden, of which two trees were lost, is the only species recommended by the city. The Norway maple, and tree of heaven are invasive species and are dangerous for the urban forest (Sibley, 2009). Two Norway maple trees and five tree of heaven trees were lost. In between the two inventory years, seven native trees and 13 non-native trees were newly planted. The five native trees include the eastern white cedar, Kentucky coffee tree, paper birch, red maple, and redbud. Of these trees, the Kentucky coffee tree and red maple are the only city recommended species. The non-native species that have seen an increase include the gingko, little leaf linden, Norway maple, Norway spruce, tree of heaven, tulip tree, and white mulberry. Four of these species are invasive trees, while three species are recommended trees.

In front of these unimproved homes, many trees have died or been removed. The area has seen a loss of invasive trees, which are harmful to the urban forest. The loss of these species does diminish the urban canopy but is beneficial for the urban forest in the future. However, unimproved homes have seen a greater loss in more valuable species of trees, as four native trees have been completely removed, while non-native trees that do not exhibit aggressive nature have been lost as well. These trees are all valuable to the urban forest, and their loss diminishes its 
diversity. The total number of trees between the two inventory years has diminished from 67 trees, to 56 trees. Although the number of trees has declined, the variety of species has increased, from 25 species to 27 species, between 2007 and 2016. The increase in species due to the introduction of new species in the neighbourhood, three of which are city recommended species, while two are species that are native to southern Ontario. The introduction of new species and new trees in front of unimproved homes can benefit the urban forest and canopy in the future, as these trees will mature and form dense crowns, while providing a wide variety of benefits to the residents of the area. However, many more trees have been removed from in front of these homes than have been added. More trees that are native or city recommended need to be added in front of these homes to make this area a more productive part of the urban forest and canopy.

The City of Toronto is actively trying to increase tree cover within the city by planting more suitable species. During the questionnaire, the respondents were asked whose decision it was to plant the tree in front of their home. Approximately $72 \%$, or 38 respondents, stated that it was the city's decision to plant the tree in front of their home, while $22 \%$, or 12 respondents stated that it was their personal decision to plant the tree, and $6 \%$, or 3 respondents, stated that they were unsure. The results of the questionnaire seem to add to the inventory, as a large number of new trees are city recommended species. The responses to the questionnaire show that these new, city recommended trees have likely been planted by the City of Toronto rather than the homeowners. However, as many trees are not city recommended species, these trees are likely either adventive species or have been planted by residents. The respondents that indicated that it was their decision to plant trees may have planted species that are not city recommended species. 
The questionnaire also asked residents if they had any plans to add trees to their property in the future. Out of the 53 respondents, approximately $32 \%$, or 17 respondents, stated that they had no immediate plans to add trees to their property, approximately 43\%, or 23 respondents, answered that they were unsure and left it up to the City to decide whether or not to plant trees in front of their home. From these responses, the residents of the study area seem to place their trust in the City to make the correct choices regarding trees within the neighbourhood. Approximately $25 \%$, or 12 respondents, stated that they were planning to add trees in the future. These residents were then asked if they knew which species of tree they wanted to add to the front of their home. Of these 12 respondents, nine were unsure what kind or species of trees they wanted, while one respondent answered that they wanted large and colourful trees to make their property and the surrounding area more appealing, and two respondents stated that they specifically wanted hedge trees on their property. This preference for hedge trees is evident in the study area as the eastern white cedar species is a hedge tree that has experienced a significant increase in number. Although this species is not a recommended species by the City of Toronto as a tree on public road allowances, it is being cultivated as an ornamental and hedge-tree in this neighbourhood and has increased in number from 43 trees in 2007, to 146 in 2016.

The questionnaire went on further to ask respondents if they had noticed an increase in the number and attractiveness of trees being planted as a result of the redevelopments occurring in their neighbourhood. Approximately 47\%, or 25 respondents, stated that they were unsure about how many trees were removed or planted in the study area, while 53\%, or 28 respondents, stated that they noticed that a small number of new trees had been planted recently. These same 28 residents believed that these trees were attractive and brought beauty and serenity into their neighbourhood. Although both the city and residents have aided in changing the structure of the 
urban trees in this study area, it seems that slightly over half of the respondents have noticed the changes and find them to be appealing. Despite this, the species and number of trees has changed between the two inventory years, and with the City's commitment to planting new and more suitable species for urban landscapes, one can expect to see more changes in the future.

In this thesis research, the tree inventory method was used to collect information regarding the species and type of housing within the study area, as well as if these homes had been renovated or not. The hypothesis that was tested using this method was that gentrification is associated with an increase in trees and tree species. This hypothesis cannot be tested statistically, as it is a comparison of trees between two different points in time. As trees aid in increasing property value, the incentive for homeowners to maintain their property, through increasing the appeal of their home, rises (Heynen, 2006; Merse et al., 2008; Escobedo et al., 2014). In the study area overall, there has been an increase in species and number of trees in front of homes. However, these changes vary, as some sections of the study area have experienced decreases, while others have experienced increases. The construction of stacked townhomes shows how gentrification can lead to a decrease in the number of species of trees, as many trees were removed. Although some trees and species were added after the construction of these homes, many more had been removed. The construction of housing is not the only evidence of gentrification, as the renovation of existing homes is also indicative of the process (Ley, 1986; Helms, 2003). In front of renovated homes there has been an increase in both the number and variety of species within the study area. Along with this, non-renovated homes have also seen an increase in species, although the number of trees has decreased by a small number. When a home is not renovated, there is little incentive for homeowners to add trees to their property (Baum, 1993; Wyly, \& Hammel, 1999; Glaeser \& Gyourko, 2005). The value and 
appeal of the home may not be a concern for owners of non-renovated homes, and thus adding trees may not interest these homeowners. However, owners of gentrified housing are more interested in increasing the value and appeal of their homes, and the larger number and variety of species of trees planted in front of these homes reflects this. Although the land front of these homes is owned by the City of Toronto, there are numerous new trees that are not city recommended and have likely been planted by owners of renovated property in the study area. Despite unimproved homes not having as many trees as improved homes do, the city is still interested in maintaining the urban forest, as recommended trees have been planted across renovated and non-renovated homes alike.

\subsection{Tree Health}

As a neighbourhood continues to change the structure of the urban forest changes with it, as trees and species are removed and introduced. The survival of the urban forest not only relies on the variety of species, but it depends heavily on the care and condition of these trees as well. The health of trees is vital to maintaining the urban forest, as healthier trees have greater ecological, social and economic benefits, and the various issues that trees faces, such as diseases, physical injuries, and climate conditions, can reduce the health and the value of the urban forest (Nowak et al, 1996; Nowak et al., 2010). This thesis research not only focused on tree species change in the Junction Triangle study area but investigated the condition of trees as well. During the tree inventory, the condition of each individual tree was recorded, and a health rating system was used to assign a number to the tree, representing the severity of the trees injuries. The results of the inventory calculated the means for trees located both on public land and in front of homes. 
The average rating for trees located on boulevards, parks, and along the West Toronto Railpath is 1.04, while the mean rating for trees located in front of housing is 0.65 . Using SPSS, a Mann-Whitney U test was conducted to determine if there was a statistically significant difference between the two means. In this thesis research, trees in front of housing in the study area were hypothesized to be in better condition than trees located on public land. The MannWhitney U analysis, which is shown in Appendix 4.2, showed that the $z$ score $=-5.67$, and the $p$ value $=1.40 \times 10^{-8}$. As the $p$ value is lower than the alpha level of 0.05 , this analysis shows that there is a statistical difference between the means of the two samples. This statistical difference shows that there is something that is occurring that is making the trees in front of homes healthier than trees on public land.

\subsubsection{Tree Health on Public Land}

In the Junction Triangle study area, public lands have changed through the construction and renewal of streets and the West Toronto Railpath. Although the renewal of public infrastructure maintains the physical health of the city, the urban forest may be damaged. Through construction and other related disturbances, the health of trees may suffer and cause their death (Wolch et al., 2014). Trees are an essential component of a city's infrastructure and unhealthy trees need to be replaced for a more functional urban forest (Wolch et al., 2014). As in section 5.2.1, this section will examine trees in the three main areas of public land: trees on boulevards, trees located in parks, and trees growing along the West Toronto Railpath. Table 13 shows the average condition ratings for trees on public land. Using three separate Mann-Whitney 
U tests, shown in Appendix 4.2 to 4.4, the ratings of boulevards, parks, and the West Toronto Railpath were compared. A multiple comparisons test was not used here (e.g. Kruskal-Wallis), and it is acknowledged that this may inflate the Type I error rate. However, as all $p$ value for all paired comparisons, were less than or equal to 0.02 , the use of the Mann-Whitney U test was likely sufficient.

Table 13: Public land condition
ratings.
\begin{tabular}{|l|l|}
\hline Location & $\begin{array}{l}\text { Average } \\
\text { Condition } \\
\text { Rating }\end{array}$ \\
\hline $\begin{array}{l}\text { All public land } \\
\text { trees }\end{array}$ & 1.04 \\
\hline Parks & 2.07 \\
\hline Boulevards & 1.54 \\
\hline $\begin{array}{l}\text { West Toronto } \\
\text { Railpath }\end{array}$ & 0.72 \\
\hline
\end{tabular}

The test between boulevard and park trees gave a $z$ score of -2.27 and a $p$ value of 0.02 . The test between boulevard and trees along the West Toronto Railpath showed a $z$ score of -5.01 , and a $p$ value of $5.25 \times 10^{-7}$. Last, the test between park trees and railpath trees showed a $z$ score equal to -8.58 , and a $p$ value of $9.8 \times 10^{-18}$. The Mann-Whitney $\mathrm{U}$ tests show that the differences between the three sections of public land are statistically different.

The section of public land that had the least healthy trees were parks. As discussed in section 5.2.1 the two parks within the study area have not been maintained very well, as a number of trees have been removed but not replaced with more trees and more species suitable for urban parks. The removal of trees in parks may be related to poor health, as the trees that are remaining within these two parks exhibit a variety of injuries. Figure 9 show two examples of park trees that exhibit a variety of defects.

As shown in Table 13, the mean condition rating for trees located in parks is 2.07. Higher condition ratings represent poor health, and this rating is the worst average rating among all areas of land within the study area, signifying that park trees are in very bad condition. During the inventory, no tree within the two parks were recorded to be in good condition, having a rating of 0 . The poor health of these trees stems from them having multiple defects on each individual tree, the most common injuries being tree lean and cracks along the trunk. Of the 57 trees located 
within parks, 33 have experienced tree lean, and 15 experienced cracks along the trunk. A tree that is leaning suggests that it has weak root systems that is not able to keep the weight of the tree balanced, while the cracks on the main stem of the tree suggests that the tree experienced mechanical damage, or is suffering from decay from fungus or pests (Albers \& Hayes, 1993; Angwin et al., 2012).
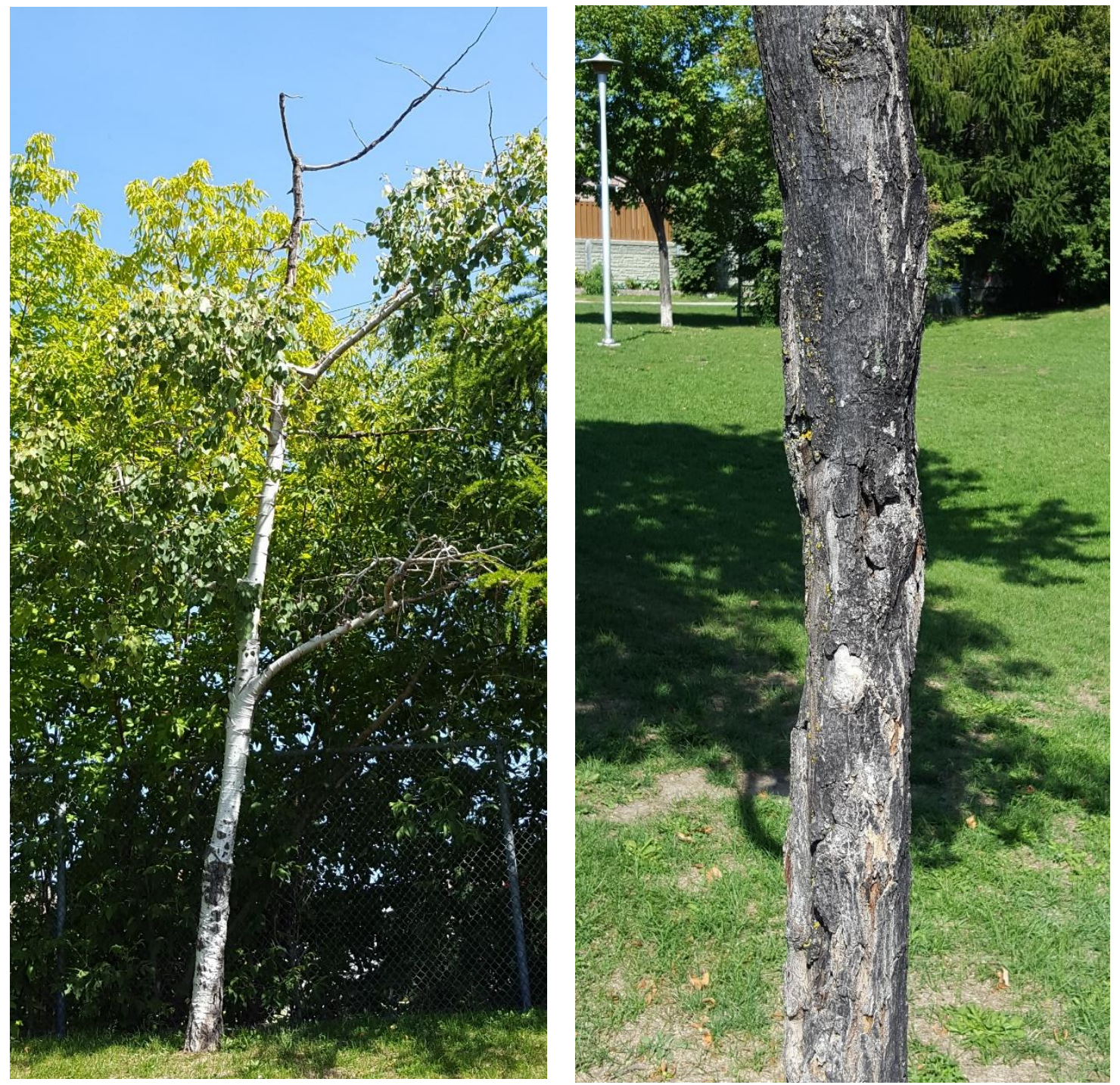

Figure 9: Park trees showing extensive damage.

Both of these defects are extremely serious and hazardous, especially in parks as they may cause the tree to fail and harm those in the vicinity of the tree. Furthermore, trees in poor 
condition may not be able to provide the same environmental, social, and economic benefits to residents and the surrounding area as trees in better health can. This diminishes the value of parks to the urban forest. These unhealthy trees show that the City of Toronto is not only removing trees and not replacing them with healthy trees and more suitable species, but they also have not been maintaining the trees that are currently there. When inspecting these two parks, no maintenance activities were visibly apparent, such as pruning, or mulching. When existing trees are not maintained properly, the health of trees is diminished which negatively effects the value and health of the urban forest, which the City of Toronto has a commitment to maintain and expand. Although Toronto is a large city containing millions of trees, if the city can remove and replace trees on public land, they can maintain the existing trees as well.

Trees along boulevards are an example of a section of public land that the city has focused upon more, as many trees have been removed in favour of trees more suitable for urban environments. However, despite this focus on the removal and replacement of trees, the health of trees along boulevards is still poor, as boulevard trees have an average condition rating of 1.54 , meaning trees along boulevards on average have experienced minor to moderate injuries. Although this rating is better than trees in parks, it still shows that these trees are not in good condition. This can mainly be attributed to the proximity of construction and restoration projects to many of these trees. During the inventory, 16 of the 52 trees recorded on boulevards were in proximity of upgrades being made to the West Toronto Railpath or adjacent to construction on the scrapyard along Elsie Lane, which is the site of a new housing project. The disturbances that construction causes have aided in the declining health of these trees, as these 16 trees specifically stood out from the other boulevard trees for exhibiting a variety of serious injuries, such as crown dieback, cracks along the trunk, and tree lean. Due to these defects, the overall quality of 
boulevard trees has decreased. The average health rating of these trees near construction was 2.25 , whereas trees on boulevards that were not located near construction was 1.22. A MannWhitney $\mathrm{U}$ test was performed for these trees and the results gave a $z$ score equal to -2.91 and a $p$ value of $4 \times 10^{-3}$, showing that these means are statistically different from one another. Seven of these 16 trees near construction were older trees, while nine were more recently planted. These older trees were located near redevelopments being made to the West Toronto Railpath, which has had improvements continuously made to it for a number of years (City of Toronto, 2013). In this time, these older trees near construction have accumulated injuries and defects but have not been removed. Older trees that have experienced injuries are much harder to remove due to their size, while damaged younger trees are much easier to remove and replace. The presence of these older trees and trees near redevelopments has contributed to the poor average condition of trees along boulevards.

As opposed to boulevards and parks, the area of public land that had the highest quality trees is the West Toronto Railpath. As shown in Figure 8, the trees along the footpath have been growing wildly. Despite this lack of maintenance, the West Toronto Railpath had a very good average condition rating, 0.72 . A large part of this low condition rating is that the large majority of trees are new trees, many of them being saplings, with minimal or no visible damage. As stated in section 5.3.1, out of the 265 total trees, 234 of them are new to the railpath, while 31 are older. Twenty-eight of these new trees are listed on the City of Toronto's recommended tree list and are resistant to many stressors that urban environments offer, allowing them to stay healthier longer than trees who are not as resilient to urban stressors (Sibley, 2009; City of Toronto, no date). While only 28 trees are city recommended, 206 newly growing trees are adventive trees that are not listed on the city's tree planting brochure and have been growing wildly. Of these 
new trees, 130 were recorded to be in good condition, having a rating of 0 with no visible defects. The large majority of these undamaged trees are saplings, which keeps the average rating of the railpath low. The average rating for the older trees along the West Toronto Railpath is 1.12 , whereas the average rating for the newly growing trees is 0.66 . The Mann-Whitney $\mathrm{U}$ analysis, available in Appendix 4.7, gave a $z$ score of -1.86 , and a $p$ value of 0.06 . The test showed that the means were not statistically different. During the inventory, it was apparent that the city has not really focused on maintaining the area. Although there are city recommended tree planted along the path, the large majority of trees are invasive adventive trees. These invasive species can inhibit the growth of native species and can be detrimental to the health of native plants (Sibley, 2009). The removal of these trees, and the replacement with younger and healthier trees, would help maintain the value of the urban forest of Toronto.

Newer trees, regardless of whether they are adventive or city planted, have played a large part in keeping a low average rating of trees in on public land within the study area. Although newer trees that have accumulated damage are much easier to remove and replace than older trees are, the large number of new trees that have been planted or are growing naturally, especially along the West Toronto Railpath, has had a noticeable impact on the condition ratings of trees on public land. This is evidenced by trees within parks, as the two parks within the study area have had no new trees added to them, and the trees that are there are in poor condition, with no maintenance activities taking place to ensure the health of these trees. Despite the West Toronto Railpath trees being, on average, in good condition, the public land as a whole still requires a lot of maintenance. Many trees and species not only need to be removed and replaced, but the health of trees needs to be taken into consideration through maintenance activities that 
ensure that trees will be healthier for a longer period of time, as these activities and actions play a large role in preserving the value of the urban forest.

\subsubsection{Tree Health in front Of Homes}

As opposed to trees located on public land, particularly those in parks, trees that have been planted in front of homes are much higher in quality, having a mean condition rating of 0.63. The types of housing within the study area include semi-detached housing, row homes, stacked townhomes, and low-rise apartments. Gentrification in the neighbourhood has most noticeably changed the semi-detached homes within the neighbourhood, as most of these types of homes have undergone renovations. During the inventory, semi-detached homes were examined and recorded as either improved or unimproved. Of the 448 semi-detached homes in the study area, 275 had been improved, having had major renovations conducted on them, such as reconstructed roofs, walls, gutters, porches, windows, doors, fences, new paint, sandblasted brick, and prominent signage (Hammel and Wyly, 1996). Homeowners choose to conduct renovations on their homes not only for maintenance, but to make it more appealing as well (Beauregard, 1986; Baum, 1993; Wilson et al, 2013). Improving the physical quality and design of a building increasingly affects resale and rental values (Baum, 1993; Glaeser \& Gyourko, 2005; Lees et al., 2008). In gentrifying neighbourhoods, profit from resale is one of the top priorities (Ley, 1986; Wyly, \& Hammel, 1999; Lees et al., 2008).

Trees play a large part in increasing the beauty of a home, as planting healthy and attractive trees have been proven to improve the aesthetics of the urban landscape (Anderson \& Cordell, 1988; Firehock, 2015; Johnston, 2015). Maintaining the health of a tree is important as 
trees in good condition are much more attractive than those that are damaged or injured. Trees in good condition offer improved environmental, economic and social benefits to the surrounding area (Dwyer et al., 1992; Nowak et al., 2006; Manes et al. 2008; Wolch et al., 2014). As homeowners who have renovated their home have participated in the gentrification of the study area, investigating trees in front of improved and unimproved homes helps to understand how the process has affected the health of these trees. The hypothesis that is being tested here is that trees in front of improved homes are in better condition than those located in front of unimproved homes.

A total of 429 trees are planted in front of semi-detached homes, 229 of which are new trees. In front of improved homes specifically, there are 310 trees, 176 of which are new. Trees outside of these homes have a very good average condition rating, 0.53 , which is the lowest and best mean rating in the study area. In front of unimproved homes, there are 56 trees in front of non-renovated homes, 20 of which are new. Trees outside of non-renovated homes have a condition rating of 0.98 . A Mann-Whitney $U$ test was conducted between the ratings of trees in front of improved homes and unimproved homes. The test gave a $z$ score of -4.82 and a $p$ value of $1 \times 10^{-6}$ showing that there is a statistical difference between the two groups. These condition ratings show that trees in front of non-renovated homes, on average, have minor injuries and are in worse condition than trees in front of renovated homes. These results are different than what has been found in research conducted by Steenberg et al. (2017). Their research found that higher instances of building permits and housing renovations led to higher tree mortality (Steenberg et al., 2017). However, in this thesis research, what was found was that homes that had undergone renovations had trees in better condition. Construction and restoration projects damage trees and lead to poor health and possibly death, as seen with trees along boulevards. 
Despite this, trees located in front of homes that have had improvements made have a low average condition rating, meaning that they are in good health.

Out of the total number of trees in front of improved homes, 197 were recorded as being in good condition. These trees did not show any visible injuries or defects and were given a rating of 0 . The most common defects seen on trees in front of improved homes was defoliation and tree lean. The defoliation of leaves shows that pests and bugs are eating away at the leaves of these trees, while tree lean shows that these trees have weak root systems, and the weight of the trees is too much for the roots to bear (Albers \& Hayes, 1993; Angwin et al. 2012). The trees in front of renovated homes that are in good condition are a mix of new trees and trees that remained from the 2007 inventory. Of the 197 trees with a good condition rating, 131 are newly planted, and 66 are older trees. All of these trees, as well as many trees that had higher ratings and experienced minor or moderate injuries, showed signs of tree care and maintenance. The trees that had the worst ratings in the area and exhibited major defects did not have any signs of tree care activities. Many of the healthier trees that have been newly planted, whether they are city or resident planted, have stakes to balance them and hold them up until their roots strengthen and are able to support the weight of the tree. Trees in good condition have also had mulch and fertilizer added to help hold moisture and add nutrients back into the soil, allowing these trees to grow and stay healthy. Evidence of pruning is also visible on numerous trees in front of renovated homes, although stakes, mulch, and fertilizer were more commonly seen. Many trees have been pruned to clear any decaying, broken, or dead branches, allowing room for new shoots to grow, and preventing the spread of fungus, parasites, or other pathogens throughout the tree.

Trees in front of gentrified homes are being taken care of more than those in front of unimproved homes, as trees in front of these homes have a condition rating of 0.98. Like those in 
front of renovated housing, the newer trees tend to be in better condition. These trees have been planted more recently and may not have had the time to experience excessive damage caused by environmental and biological conditions or human involvement. However, the main difference between these two categories of housing is that, during the inventory, there were no visible actions or activities taking place for their well-being. Since renovated homes have trees that are staked, pruned, and with soil containing mulch and fertilizer, while non-renovated homes do not, this suggests that it is the residents that are participating in tree care practices rather than the city. As trees aid in increasing property value, the incentive for home owners to maintain their property value, through increasing the appeal of their home, rises (Heynen, 2006; Merse et al., 2008; Escobedo et al., 2014). However, when a home is not renovated, there is little incentive for homeowners to maintain trees on their property (Baum, 1993; Wyly, \& Hammel, 1999; Glaeser \& Gyourko, 2005).

As the trees outside of semi-detached homes are in much better health than those located on public land, the residents of this study seem to find trees to be a valuable resource worth maintaining. It is possible to understand why residents may feel this way by analyzing the responses to the questionnaire, the full results of which are available in Appendix 3.4. The questionnaire was handed out to residents who live in semi-detached homes, as gentrification has most visibly changed this form of housing. The responses to the questionnaire showed that 42 respondents, or approximately $79 \%$ found trees to be an important and valuable asset to their neighbourhood, while 13\% remained neutral, and $8 \%$ did not find trees to be an asset.

Those respondents who did appreciate and value trees, believed that urban trees provided many positive environmental benefits and improved the quality of their neighbourhood, by providing the community improved aesthetics, reduced cooling and heating costs, improved air 
quality, and increased housing value. Of these 42 respondents, $86 \%$, or 36 respondents, stated that they believed that trees needed to be maintained, and participated in tree care activities to maintain the tree outside of their home, while 3 respondents stated they did not have trees outside of their home, and 3 more respondents did not take any action and stated that they left maintenance solely up to the city. The respondents who did maintain their tree participated in different combinations of tree care practices, such as pruning, mulching, adding fertilizer, and watering trees. Eighteen of these 36 respondents, or 50\%, stated that they watered their trees consistently but left the city to deal with any other health issues that the trees may have, including removal and replacement. The other $50 \%$ of respondents stated that they watered their trees and participated in other actions, such as pruning branches, and adding mulch and fertilizer to the tree's soil. All of these practices that residents are participating in are for the well-being of the tree outside of their home. Three of the 36 respondents, approximately $8 \%$, stated that they lived in non-renovated homes, while 33 respondents, $92 \%$, stated that they lived in a home that had been renovated. These three respondents stated that they only watered the tree and did not maintain their tree in any other way. The respondents that renovated their home actively maintained their tree through a combination of different care practices. These responses correlate with what has been seen in the inventory, as trees in front of renovated homes have a very good average condition and have visible evidence of tree maintenance.

Out of the 53 total responses, four respondents, or approximately $8 \%$, did not find trees to be a valuable asset. The residents answered that they disliked trees and viewed forestry negatively, stating that they do not believe trees improve the quality of their home or neighbourhood. As a result of this negative view, these residents have done nothing to actively maintain their tree, answering that they let the city take care of the trees in front of their homes. 
Three of these residents live in non-renovated housing, while the other respondent lived in a home with renovations. Seven respondents, approximately $13 \%$, remained neutral, stating that they neither liked nor disliked the trees in the neighbourhood. These respondents seemed to not be quite sure about whether trees increased the quality of their home and the neighbourhood, or whether they provided key environmental benefits. All of these respondents stated that they did not actively maintain their trees and entrusted the city with maintenance. Five of the seven respondents, or $71 \%$, stated that they lived in a non-renovated home, while the other $19 \%$ lived in renovated homes. These responses towards trees may be contributing to some of the lower quality trees located in front of non-renovated homes. The majority of respondents who lived in non-renovated homes do not see trees as valuable, or are neutral towards them, and do not actively maintain the trees outside of their homes. These responses agree with what has been seen in the tree inventory, as non-renovated homes have lower quality trees than renovated ones.

In this thesis research, the tree inventory and questionnaire method were used to gain information about the health of trees in front of homes as well as tree care and maintenance practices conducted by residents. These methods were used to test the third and fourth hypotheses, that trees in front of improved homes are healthier than those in front of unimproved homes, and that trees in front of all housing in the study area are in better condition than those located in public areas. Overall, trees planted in front of homes are in better health than those growing on public land. The number of newer trees with little to no visible damage in front of homes in the study area contributes to a lower and better average condition rating. On public land, such as parks and boulevards, there are many more damaged and unhealthy trees than in front of homes. Furthermore, trees outside of housing have visible evidence of maintenance, contributing to a lower and better mean condition rating. Maintenance by residents further 
contributes to the good mean condition rating, as the majority of residents seem to view trees as beneficial to the environment and society. Actions such as pruning, adding mulch and fertilizer, watering trees, and staking young trees are all helping keep the quality of urban trees in this study area high. Improved homes have more evidence of tree care practices than unimproved homes do, which leads to these renovated homes having a better mean condition rating than nonrenovated and deteriorated housing. Tree maintenance is an essential aspect of maintaining the urban forest, and as citizens continue to participate in tree care activities, a healthier urban forest is ensured. Benefits from trees increase as they grow. If systematic pruning and maintenance is applied, the result is a healthy tree population that can provide a wide variety of benefits to the population (Miller and Sylvester, 1981). However, the city needs to take more action as they have a commitment to preserve the urban forest as well, not just through the removal and replacement of trees, but through the proper management of existing trees as well. The costs of providing regular tree care are small when compared with the value of benefits lost when maturing trees become unhealthy and die (McPherson et al., 1991). Efficiently delivered tree care can more than pay for itself by improving health, increasing growth, and extending longevity (Miller and Sylvester, 1981; McPherson et al., 1997). 


\section{Chapter 6: Conclusions and Recommendations}

The Junction Triangle neighbourhood is currently undergoing the process of gentrification. The changes associated with gentrification affect the physical, social, and economic aspects of a neighbourhood. The conclusions that can be drawn from this study can help future researchers understand the environmental impact that gentrification has more clearly. The findings of this research show that there is good evidence the study area is gentrifying, as both the physical structure and socio-economic characteristics of have changed over the past years. Although gentrification takes many decades to fully transform a neighbourhood, the study area has visibly started to experience the process. One of the purposes of this research was to investigate if there was a difference in opinions regarding gentrification between residents who have moved in more recently and residents who have lived in the neighbourhood for a long period of time. What was found was that residents who moved in prior to 2007 viewed the redeveloping neighbourhood more negatively than residents who moved in after to 2007 . These negative views stem from the disruption that construction and housing restoration projects have, such as noise, traffic, and damage.

While the opinions of the residents of the study area is important, this thesis research also focused on if these construction and housing projects have led to an increase in the number and variety of species in the neighbourhood. This study found that there are major changes occurring in the structure of the urban forest as a result of gentrification. In the study area, there is a net 
growth of trees in both public land and in front of homes. Public infrastructure in this study area, such as boulevards and the West Toronto Railpath, is being redeveloped, and as a result many trees have been removed and replaced. On public land, large increases in both invasive and city recommended trees has been seen. However, in front of homes, invasive and non-native species have seen a decline in number. These trees have been replaced with many more city recommended and native trees. Many of these new trees and species introduced in front of homes are not city recommended trees, suggesting that homeowners and residents have been planting trees in front of homes as well. Trees in front of homes aid in the increase of property value, and in gentrifying areas one of the most important priorities is maintaining the value of the home (Ley, 1986; Wyly, \& Hammel, 1999; Lees et al., 2008). As trees aid in increasing property value, gentrifying neighbourhoods tend to see increases in tree species and cover (Heynen, 2006; Merse et al., 2008). This phenomenon is also seen in the Junction Triangle study area, as numerous trees have been planted in front of homes.

As gentrification has changed the housing of the study area, through renovations and the construction of new housing stock, the process has also affected the health of trees. This thesis research investigated the differences between health with trees in front of improved homes and unimproved homes, as well as trees in front of all housing in the neighbourhood and public land trees. What this research found was that trees in front of homes were in much better condition than those on public land. Specifically, trees in front of semi-detached homes, and new townhomes, had the best condition ratings. Furthermore, improved homes had much healthier trees than unimproved homes. This is attributed to tree maintenance activities that are occurring on trees in front of homes but are missing from those located on public land. Evidence of tree care practices, such as pruning, staking, and adding mulch and fertilizer is visible on trees in 
front of homes. Improved homes especially have higher instances of tree care than unimproved homes. Just as adding new and exotic species of trees adds beauty to a home, so too does having healthy a tree. Healthier trees are much more appealing than trees that are not well taken care of and offer a wider variety of benefits to residents and wildlife, that unhealthy trees cannot.

This thesis research has provided some evidence on how gentrification has shaped the structure of the urban forest. The methods that were used in this research helped to garner information regarding the health and variety of species in a section of the gentrifying neighbourhood of the Junction Triangle. However, gentrification is not completely identical in every city. Although housing and infrastructure is visibly altered through gentrification, these changes, as well as changes to socio-economic characteristics, will vary from region to region. These differences between areas will also affect the urban forest in a variety of ways. The methods that have been used in this thesis research were effective and can be used again in future studies. More studies that are conducted on this topic will help gather more evidence and help create a clearer understand of the relationship between gentrification and the urban forest. Along with this, a longer time span may be needed to make sure that the changes associated with gentrification are really influencing trees. As gentrification is a process that takes many years, the process is continuously affected and changing trees. A more accurate understanding of this relationship can be done through a detailed survey, including both condition and species, in a neighbourhood that is in the very early stages of gentrification. This can allow future researchers to look back and accurately determine the changes that are taking place in both the health and species of the urban forest. 


\section{Appendices:}

\section{Appendix 1: 2016 Inventory of the Junction Triangle Study Area}

Table A1 shows the tree inventory conducted in 2016. Species are shown in both as common names as well as scientific name. The tree condition and rating columns list the defects visible on the tree and the associated rating based off these defects. The location shows the location of the tree in decimal degrees, while the ownership specifies whether the tree is in front of a home, or on public land. Finally, the notes list information regarding the tree and its surrounding area, such as if the tree is new, near construction, what kind of housing it is located in front of, and if the home has been renovated or non-renovated. Table A1 is organized by the ownership column.

Table A1: The updated inventory conducted in 2016.

\begin{tabular}{|c|c|c|c|c|c|c|}
\hline Species & $\begin{array}{l}\text { Scientific } \\
\text { Name }\end{array}$ & Condition & Rating & Location & Ownership & Notes \\
\hline $\begin{array}{l}\text { American } \\
\text { Elm }\end{array}$ & $\begin{array}{l}\text { Ulmus } \\
\text { americana }\end{array}$ & good condition & 0 & $\begin{array}{l}43.660239^{\circ}, \\
-79.447783^{\circ}\end{array}$ & $\begin{array}{l}\text { In front of } \\
\text { housing }\end{array}$ & $\begin{array}{l}\text { New tree. Improved semi- } \\
\text { detached home. }\end{array}$ \\
\hline $\begin{array}{l}\text { American } \\
\text { Elm }\end{array}$ & $\begin{array}{l}\text { Ulmus } \\
\text { americana }\end{array}$ & tree lean, cracks on trunk & 2 & $\begin{array}{l}43.660330^{\circ}, \\
-79.451354^{\circ}\end{array}$ & $\begin{array}{l}\text { In front of } \\
\text { housing }\end{array}$ & $\begin{array}{l}\text { New tree. Stacked } \\
\text { townhome. }\end{array}$ \\
\hline $\begin{array}{l}\text { American } \\
\text { Elm }\end{array}$ & $\begin{array}{l}\text { Ulmus } \\
\text { americana } \\
\end{array}$ & tree lean, cracks on trunk & 2 & $\begin{array}{l}43.660350^{\circ}, \\
-79.451266^{\circ}\end{array}$ & $\begin{array}{l}\text { In front of } \\
\text { housing }\end{array}$ & $\begin{array}{l}\text { New tree. Stacked } \\
\text { townhome. }\end{array}$ \\
\hline $\begin{array}{l}\text { American } \\
\text { Elm }\end{array}$ & $\begin{array}{l}\text { Ulmus } \\
\text { americana }\end{array}$ & tree lean & 1 & $\begin{array}{l}43.660974^{\circ}, \\
-79.448097^{\circ}\end{array}$ & $\begin{array}{l}\text { In front of } \\
\text { housing }\end{array}$ & $\begin{array}{l}\text { Unimproved semi-detached } \\
\text { home. }\end{array}$ \\
\hline $\begin{array}{l}\text { American } \\
\text { Elm }\end{array}$ & $\begin{array}{l}\text { Ulmus } \\
\text { americana }\end{array}$ & good condition & 0 & $\begin{array}{l}43.657619^{\circ}, \\
-79.447531^{\circ}\end{array}$ & $\begin{array}{l}\text { In front of } \\
\text { housing }\end{array}$ & $\begin{array}{l}\text { Improved semi-detached } \\
\text { home. }\end{array}$ \\
\hline $\begin{array}{l}\text { American } \\
\text { Elm }\end{array}$ & $\begin{array}{l}\text { Ulmus } \\
\text { americana }\end{array}$ & tree lean, defoliation & 2 & $\begin{array}{l}43.659133^{\circ}, \\
-79.447318^{\circ}\end{array}$ & $\begin{array}{l}\text { In front of } \\
\text { housing }\end{array}$ & $\begin{array}{l}\text { Improved semi-detached } \\
\text { home. }\end{array}$ \\
\hline $\begin{array}{l}\text { American } \\
\text { Elm }\end{array}$ & $\begin{array}{l}\text { Ulmus } \\
\text { americana }\end{array}$ & tree lean, defoliation & 2 & $\begin{array}{l}43.660539^{\circ}, \\
-79.450478^{\circ}\end{array}$ & $\begin{array}{l}\text { In front of } \\
\text { housing }\end{array}$ & $\begin{array}{l}\text { Improved semi-detached } \\
\text { home. }\end{array}$ \\
\hline $\begin{array}{l}\text { American } \\
\text { Elm }\end{array}$ & $\begin{array}{l}\text { Ulmus } \\
\text { americana }\end{array}$ & good condition & 0 & $\begin{array}{l}43.660785^{\circ}, \\
-79.448260^{\circ}\end{array}$ & $\begin{array}{l}\text { In front of } \\
\text { housing }\end{array}$ & $\begin{array}{l}\text { Improved semi-detached } \\
\text { home. }\end{array}$ \\
\hline $\begin{array}{l}\text { American } \\
\text { Elm }\end{array}$ & $\begin{array}{l}\text { Ulmus } \\
\text { americana }\end{array}$ & good condition & 0 & $\begin{array}{l}43.660841^{\circ}, \\
-79.451118^{\circ}\end{array}$ & $\begin{array}{l}\text { In front of } \\
\text { housing }\end{array}$ & $\begin{array}{l}\text { Improved semi-detached } \\
\text { home. }\end{array}$ \\
\hline Apricot Tree & $\begin{array}{l}\text { Prunus } \\
\text { armeniaca }\end{array}$ & $\begin{array}{l}10 \% \text { dieback, defoliation, } \\
\text { tree lean }\end{array}$ & 2 & $\begin{array}{l}43.659502^{\circ}, \\
-79.448530^{\circ}\end{array}$ & $\begin{array}{l}\text { In front of } \\
\text { housing }\end{array}$ & $\begin{array}{l}\text { Improved semi-detached } \\
\text { home. }\end{array}$ \\
\hline Apricot Tree & $\begin{array}{l}\text { Prunus } \\
\text { armeniaca }\end{array}$ & $\begin{array}{l}10 \% \text { dieback, defoliation, } \\
\text { tree lean }\end{array}$ & 2 & $\begin{array}{l}43.659515^{\circ}, \\
-79.448521^{\circ}\end{array}$ & $\begin{array}{l}\text { In front of } \\
\text { housing }\end{array}$ & $\begin{array}{l}\text { Improved semi-detached } \\
\text { home. }\end{array}$ \\
\hline $\begin{array}{l}\text { Austrian } \\
\text { Pine }\end{array}$ & Pinus nigra & $\begin{array}{l}70 \% \text { dieback, weak branch } \\
\text { unions, cracks on trunk }\end{array}$ & 3 & $\begin{array}{l}43.657652^{\circ}, \\
-79.449283^{\circ}\end{array}$ & $\begin{array}{l}\text { In front of } \\
\text { housing }\end{array}$ & Low-rise apartment. \\
\hline $\begin{array}{l}\text { Austrian } \\
\text { Pine }\end{array}$ & Pinus nigra & $\begin{array}{l}70 \% \text { dieback, weak branch } \\
\text { unions, cracks on trunk }\end{array}$ & 3 & $\begin{array}{l}43.657706^{\circ}, \\
-79.449362^{\circ}\end{array}$ & $\begin{array}{l}\text { In front of } \\
\text { housing }\end{array}$ & Low-rise apartment. \\
\hline $\begin{array}{l}\text { Austrian } \\
\text { Pine }\end{array}$ & Pinus nigra & $\begin{array}{l}\text { good condition. Has been } \\
\text { pruned, new shoots } \\
\text { forming. }\end{array}$ & 0 & $\begin{array}{l}43.659498^{\circ}, \\
-79.448527^{\circ}\end{array}$ & $\begin{array}{l}\text { In front of } \\
\text { housing }\end{array}$ & $\begin{array}{l}\text { New tree. Improved semi- } \\
\text { detached home. }\end{array}$ \\
\hline $\begin{array}{l}\text { Austrian } \\
\text { Pine }\end{array}$ & Pinus nigra & peeling bark & 1 & $\begin{array}{l}43.660379^{\circ}, \\
-79.447866^{\circ}\end{array}$ & $\begin{array}{l}\text { In front of } \\
\text { housing }\end{array}$ & $\begin{array}{l}\text { Improved semi-detached } \\
\text { home. }\end{array}$ \\
\hline
\end{tabular}




\begin{tabular}{|c|c|c|c|c|c|c|}
\hline $\begin{array}{l}\text { Austrian } \\
\text { Pine }\end{array}$ & Pinus nigra & tree lean & 1 & $\begin{array}{l}43.660500^{\circ}, \\
-79.447901^{\circ} \\
\end{array}$ & $\begin{array}{l}\text { In front of } \\
\text { housing }\end{array}$ & $\begin{array}{l}\text { Improved semi-detached } \\
\text { home. }\end{array}$ \\
\hline $\begin{array}{l}\text { Austrian } \\
\text { Pine }\end{array}$ & Pinus nigra & good condition & 0 & $\begin{array}{l}43.658300^{\circ}, \\
-79.447228^{\circ}\end{array}$ & $\begin{array}{l}\text { In front of } \\
\text { housing }\end{array}$ & Row home. \\
\hline $\begin{array}{l}\text { Austrian } \\
\text { Pine }\end{array}$ & Pinus nigra & dead/broken branches & 2 & $\begin{array}{l}43.658284^{\circ}, \\
-79.447148^{\circ}\end{array}$ & $\begin{array}{l}\text { In front of } \\
\text { housing }\end{array}$ & Stacked townhome. \\
\hline Balsam Fir & $\begin{array}{l}\text { Abies } \\
\text { balsamea }\end{array}$ & good condition & 0 & $\begin{array}{l}43.659129^{\circ} \\
-79.447544^{\circ}\end{array}$ & $\begin{array}{l}\text { In front of } \\
\text { housing }\end{array}$ & $\begin{array}{l}\text { Unimproved semi-detached } \\
\text { home. }\end{array}$ \\
\hline Basswood & Tilia americana & good condition & 0 & $\begin{array}{l}43.658722^{\circ}, \\
-79.447408^{\circ}\end{array}$ & $\begin{array}{l}\text { In front of } \\
\text { housing }\end{array}$ & $\begin{array}{l}\text { New tree. Improved semi- } \\
\text { detached home. }\end{array}$ \\
\hline Basswood & Tilia americana & good condition & 0 & $\begin{array}{l}43.660539^{\circ}, \\
-79.450251^{\circ}\end{array}$ & $\begin{array}{l}\text { In front of } \\
\text { housing }\end{array}$ & $\begin{array}{l}\text { New tree. Improved semi- } \\
\text { detached home. }\end{array}$ \\
\hline Basswood & Tilia americana & cracks on trunk & 1 & $\begin{array}{l}43.659447^{\circ}, \\
-79.447663^{\circ}\end{array}$ & $\begin{array}{l}\text { In front of } \\
\text { housing }\end{array}$ & $\begin{array}{l}\text { Improved semi-detached } \\
\text { home. }\end{array}$ \\
\hline Basswood & Tilia americana & $\begin{array}{l}\text { weak branch unions, cracks } \\
\text { on trunk }\end{array}$ & 2 & $\begin{array}{l}43.660314^{\circ}, \\
-79.450132^{\circ}\end{array}$ & $\begin{array}{l}\text { In front of } \\
\text { housing }\end{array}$ & $\begin{array}{l}\text { Improved semi-detached } \\
\text { home. }\end{array}$ \\
\hline $\begin{array}{l}\text { Big Leaf } \\
\text { Maple }\end{array}$ & $\begin{array}{l}\text { Acer } \\
\text { macrophyllum }\end{array}$ & good condition & 0 & $\begin{array}{l}43.660474^{\circ}, \\
-79.450405^{\circ}\end{array}$ & $\begin{array}{l}\text { In front of } \\
\text { housing }\end{array}$ & $\begin{array}{l}\text { New tree. Improved semi- } \\
\text { detached home. }\end{array}$ \\
\hline Black Maple & Acer nigrum & cracks on trunk & 1 & $\begin{array}{l}43.658343^{\circ}, \\
-79.449311^{\circ}\end{array}$ & $\begin{array}{l}\text { In front of } \\
\text { housing }\end{array}$ & $\begin{array}{l}\text { New tree. Improved semi- } \\
\text { detached home. }\end{array}$ \\
\hline Black Maple & Acer nigrum & tree lean & 1 & $\begin{array}{l}43.660136^{\circ}, \\
-79.450259^{\circ}\end{array}$ & $\begin{array}{l}\text { In front of } \\
\text { housing }\end{array}$ & $\begin{array}{l}\text { New tree. Improved semi- } \\
\text { detached home. }\end{array}$ \\
\hline Black Maple & Acer nigrum & tree lean, cracks on trunk & 2 & $\begin{array}{l}43.660782^{\circ}, \\
-79.448027^{\circ}\end{array}$ & $\begin{array}{l}\text { In front of } \\
\text { housing }\end{array}$ & $\begin{array}{l}\text { Unimproved semi-detached } \\
\text { home. }\end{array}$ \\
\hline Blue Spruce & Picea pungens & tree lean, defoliation & 2 & $\begin{array}{l}43.657183^{\circ}, \\
-79.449744^{\circ}\end{array}$ & $\begin{array}{l}\text { In front of } \\
\text { housing }\end{array}$ & Low-rise apartment. \\
\hline Blue Spruce & Picea pungens & good condition & 0 & $\begin{array}{l}43.657196^{\circ}, \\
-79.449752^{\circ}\end{array}$ & $\begin{array}{l}\text { In front of } \\
\text { housing }\end{array}$ & Low-rise apartment. \\
\hline Blue Spruce & Picea pungens & good condition & 0 & $\begin{array}{l}43.658566^{\circ}, \\
-79.449417^{\circ}\end{array}$ & $\begin{array}{l}\text { In front of } \\
\text { housing }\end{array}$ & $\begin{array}{l}\text { New tree. Improved semi- } \\
\text { detached home. }\end{array}$ \\
\hline Blue Spruce & Picea pungens & good condition & 0 & $\begin{array}{l}43.658567^{\circ}, \\
-79.449415^{\circ}\end{array}$ & $\begin{array}{l}\text { In front of } \\
\text { housing }\end{array}$ & $\begin{array}{l}\text { New tree. Improved semi- } \\
\text { detached home. }\end{array}$ \\
\hline Blue Spruce & Picea pungens & good condition & 0 & $\begin{array}{l}43.658582^{\circ}, \\
-79.449422^{\circ}\end{array}$ & $\begin{array}{l}\text { In front of } \\
\text { housing }\end{array}$ & $\begin{array}{l}\text { New tree. Improved semi- } \\
\text { detached home. }\end{array}$ \\
\hline Blue Spruce & Picea pungens & good condition & 0 & $\begin{array}{l}43.658595^{\circ}, \\
-79.449425^{\circ}\end{array}$ & $\begin{array}{l}\text { In front of } \\
\text { housing }\end{array}$ & $\begin{array}{l}\text { New tree. Improved semi- } \\
\text { detached home. }\end{array}$ \\
\hline Blue Spruce & Picea pungens & treelean, peeling bark & 2 & $\begin{array}{l}43.660901^{\circ}, \\
-79.448052^{\circ}\end{array}$ & $\begin{array}{l}\text { In front of } \\
\text { housing }\end{array}$ & $\begin{array}{l}\text { Improved semi-detached } \\
\text { home. }\end{array}$ \\
\hline Blue Spruce & Picea pungens & tree lean, peeling bark & 3 & $\begin{array}{l}43.661056^{\circ}, \\
-79.449358^{\circ}\end{array}$ & $\begin{array}{l}\text { In front of } \\
\text { housing }\end{array}$ & $\begin{array}{l}\text { Improved semi-detached } \\
\text { home. }\end{array}$ \\
\hline Blue Spruce & Picea pungens & good condition & 0 & $\begin{array}{l}43.658082^{\circ}, \\
-79.447928^{\circ}\end{array}$ & $\begin{array}{l}\text { In front of } \\
\text { housing }\end{array}$ & Row home. \\
\hline Blue Spruce & Picea pungens & good condition & 0 & $\begin{array}{l}43.658082^{\circ}, \\
-79.447949^{\circ}\end{array}$ & $\begin{array}{l}\text { In front of } \\
\text { housing }\end{array}$ & Row home. \\
\hline $\begin{array}{l}\text { Callery Pear } \\
\text { Tree }\end{array}$ & $\begin{array}{l}\text { Pyrus } \\
\text { calleryana }\end{array}$ & good condition & 0 & $\begin{array}{l}43.660003^{\circ}, \\
-79.448732^{\circ}\end{array}$ & $\begin{array}{l}\text { In front of } \\
\text { housing }\end{array}$ & $\begin{array}{l}\text { New tree. Improved semi- } \\
\text { detached home. }\end{array}$ \\
\hline $\begin{array}{l}\text { Callery Pear } \\
\text { Tree }\end{array}$ & $\begin{array}{l}\text { Pyrus } \\
\text { calleryana }\end{array}$ & good condition & 0 & $\begin{array}{l}43.660339^{\circ}, \\
-79.448575^{\circ}\end{array}$ & $\begin{array}{l}\text { In front of } \\
\text { housing }\end{array}$ & $\begin{array}{l}\text { New tree. Improved semi- } \\
\text { detached home. }\end{array}$ \\
\hline $\begin{array}{l}\text { Callery Pear } \\
\text { Tree }\end{array}$ & $\begin{array}{l}\text { Pyrus } \\
\text { calleryana }\end{array}$ & good condition & 0 & $\begin{array}{l}43.660679^{\circ}, \\
-79.447982^{\circ}\end{array}$ & $\begin{array}{l}\text { In front of } \\
\text { housing }\end{array}$ & $\begin{array}{l}\text { New tree. Improved semi- } \\
\text { detached home. }\end{array}$ \\
\hline $\begin{array}{l}\text { Callery Pear } \\
\text { Tree }\end{array}$ & $\begin{array}{l}\text { Pyrus } \\
\text { calleryana }\end{array}$ & good condition & 0 & $\begin{array}{l}43.659568^{\circ}, \\
-79.448318^{\circ}\end{array}$ & $\begin{array}{l}\text { In front of } \\
\text { housing }\end{array}$ & $\begin{array}{l}\text { Improved semi-detached } \\
\text { home. }\end{array}$ \\
\hline $\begin{array}{l}\text { Callery Pear } \\
\text { Tree }\end{array}$ & $\begin{array}{l}\text { Pyrus } \\
\text { calleryana }\end{array}$ & good condition & 0 & $\begin{array}{l}43.659578^{\circ}, \\
-79.448301^{\circ}\end{array}$ & $\begin{array}{l}\text { In front of } \\
\text { housing }\end{array}$ & $\begin{array}{l}\text { Improved semi-detached } \\
\text { home. }\end{array}$ \\
\hline $\begin{array}{l}\text { Callery Pear } \\
\text { Tree }\end{array}$ & $\begin{array}{l}\text { Pyrus } \\
\text { calleryana }\end{array}$ & good condition & 0 & $\begin{array}{l}43.659584^{\circ}, \\
-79.448243^{\circ}\end{array}$ & $\begin{array}{l}\text { In front of } \\
\text { housing }\end{array}$ & $\begin{array}{l}\text { Improved semi-detached } \\
\text { home. }\end{array}$ \\
\hline $\begin{array}{l}\text { Callery Pear } \\
\text { Tree }\end{array}$ & $\begin{array}{l}\text { Pyrus } \\
\text { calleryana }\end{array}$ & good condition & 0 & $\begin{array}{l}43.659585^{\circ}, \\
-79.448272^{\circ}\end{array}$ & $\begin{array}{l}\text { In front of } \\
\text { housing }\end{array}$ & $\begin{array}{l}\text { Improved semi-detached } \\
\text { home. }\end{array}$ \\
\hline $\begin{array}{l}\text { Callery Pear } \\
\text { Tree }\end{array}$ & $\begin{array}{l}\text { Pyrus } \\
\text { calleryana }\end{array}$ & weak branch unions & 1 & $\begin{array}{l}43.658176^{\circ}, \\
-79.447587^{\circ} \\
\end{array}$ & $\begin{array}{l}\text { In front of } \\
\text { housing }\end{array}$ & Row home. \\
\hline $\begin{array}{l}\text { Callery Pear } \\
\text { Tree }\end{array}$ & $\begin{array}{l}\text { Pyrus } \\
\text { calleryana }\end{array}$ & cracks on trunk & 1 & $\begin{array}{l}43.658184^{\circ}, \\
-79.447622^{\circ}\end{array}$ & $\begin{array}{l}\text { In front of } \\
\text { housing }\end{array}$ & Row home. \\
\hline $\begin{array}{l}\text { Callery Pear } \\
\text { Tree }\end{array}$ & $\begin{array}{l}\text { Pyrus } \\
\text { calleryana }\end{array}$ & cracks on trunk & 1 & $\begin{array}{l}43.658218^{\circ} \\
-79.447456^{\circ}\end{array}$ & $\begin{array}{l}\text { In front of } \\
\text { housing }\end{array}$ & Row home. \\
\hline $\begin{array}{l}\text { Callery Pear } \\
\text { Tree }\end{array}$ & $\begin{array}{l}\text { Pyrus } \\
\text { calleryana }\end{array}$ & $\begin{array}{l}\text { dead/broken branches, } \\
\text { weak branch unions }\end{array}$ & 2 & $\begin{array}{l}43.658212^{\circ}, \\
-79.447537^{\circ}\end{array}$ & $\begin{array}{l}\text { In front of } \\
\text { housing }\end{array}$ & Stacked townhome. \\
\hline $\begin{array}{l}\text { Canada } \\
\text { Plum }\end{array}$ & Prunus nigra & tree lean, defoliation & 2 & $\begin{array}{l}43.659559^{\circ}, \\
-79.448342^{\circ}\end{array}$ & $\begin{array}{l}\text { In front of } \\
\text { housing }\end{array}$ & $\begin{array}{l}\text { Improved semi-detached } \\
\text { home. }\end{array}$ \\
\hline
\end{tabular}




\begin{tabular}{|c|c|c|c|c|c|c|}
\hline $\begin{array}{l}\text { Cherry plum } \\
\text { tree }\end{array}$ & $\begin{array}{l}\text { Prunus } \\
\text { cerasifera }\end{array}$ & tree lean & 1 & $\begin{array}{l}43.660292^{\circ}, \\
-79.449323^{\circ}\end{array}$ & $\begin{array}{l}\text { In front of } \\
\text { housing }\end{array}$ & $\begin{array}{l}\text { Unimproved semi-detached } \\
\text { home. }\end{array}$ \\
\hline $\begin{array}{l}\text { Cherry plum } \\
\text { tree }\end{array}$ & $\begin{array}{l}\text { Prunus } \\
\text { cerasifera }\end{array}$ & $\begin{array}{l}\text { good condition. Has been } \\
\text { pruned, new shoots } \\
\text { forming. }\end{array}$ & 0 & $\begin{array}{l}43.658700^{\circ}, \\
-79.449500^{\circ}\end{array}$ & $\begin{array}{l}\text { In front of } \\
\text { housing }\end{array}$ & $\begin{array}{l}\text { Improved semi-detached } \\
\text { home. }\end{array}$ \\
\hline $\begin{array}{l}\text { Cherry plum } \\
\text { tree }\end{array}$ & $\begin{array}{l}\text { Prunus } \\
\text { cerasifera }\end{array}$ & good condition & 0 & $\begin{array}{l}43.659529^{\circ}, \\
-79.448475^{\circ}\end{array}$ & $\begin{array}{l}\text { In front of } \\
\text { housing }\end{array}$ & $\begin{array}{l}\text { Improved semi-detached } \\
\text { home. }\end{array}$ \\
\hline $\begin{array}{l}\text { Cherry plum } \\
\text { tree }\end{array}$ & $\begin{array}{l}\text { Prunus } \\
\text { cerasifera }\end{array}$ & cracks on trunk & 1 & $\begin{array}{l}43.659541^{\circ} \\
-79.448461^{\circ}\end{array}$ & $\begin{array}{l}\text { In front of } \\
\text { housing }\end{array}$ & $\begin{array}{l}\text { Improved semi-detached } \\
\text { home. }\end{array}$ \\
\hline $\begin{array}{l}\text { Cherry plum } \\
\text { tree }\end{array}$ & $\begin{array}{l}\text { Prunus } \\
\text { cerasifera }\end{array}$ & good condition & 0 & $\begin{array}{l}43.659546^{\circ}, \\
-79.448405^{\circ}\end{array}$ & $\begin{array}{l}\text { In front of } \\
\text { housing }\end{array}$ & $\begin{array}{l}\text { Improved semi-detached } \\
\text { home. }\end{array}$ \\
\hline $\begin{array}{l}\text { Cherry plum } \\
\text { tree }\end{array}$ & $\begin{array}{l}\text { Prunus } \\
\text { cerasifera }\end{array}$ & good condition & 0 & $\begin{array}{l}43.659547^{\circ}, \\
-79.448450^{\circ}\end{array}$ & $\begin{array}{l}\text { In front of } \\
\text { housing }\end{array}$ & $\begin{array}{l}\text { Improved semi-detached } \\
\text { home. }\end{array}$ \\
\hline $\begin{array}{l}\text { Cherry plum } \\
\text { tree }\end{array}$ & $\begin{array}{l}\text { Prunus } \\
\text { cerasifera }\end{array}$ & $\begin{array}{l}\text { cracks on trunk, defoliation, } \\
\text { peeling bark, some wood } \\
\text { decay }\end{array}$ & 3 & $\begin{array}{l}43.659548^{\circ} \\
-79.448425^{\circ}\end{array}$ & $\begin{array}{l}\text { In front of } \\
\text { housing }\end{array}$ & $\begin{array}{l}\text { Improved semi-detached } \\
\text { home. }\end{array}$ \\
\hline $\begin{array}{l}\text { Cherry plum } \\
\text { tree }\end{array}$ & $\begin{array}{l}\text { Prunus } \\
\text { cerasifera }\end{array}$ & Peeling bark & 1 & $\begin{array}{l}43.659552^{\circ}, \\
-79.448387^{\circ}\end{array}$ & $\begin{array}{l}\text { In front of } \\
\text { housing }\end{array}$ & $\begin{array}{l}\text { Improved semi-detached } \\
\text { home. }\end{array}$ \\
\hline $\begin{array}{l}\text { Cherry plum } \\
\text { tree }\end{array}$ & $\begin{array}{l}\text { Prunus } \\
\text { cerasifera }\end{array}$ & $10 \%$ dieback, defoliation & 2 & $\begin{array}{l}43.659556^{\circ}, \\
-79.448358^{\circ} \\
\end{array}$ & $\begin{array}{l}\text { In front of } \\
\text { housing }\end{array}$ & $\begin{array}{l}\text { Improved semi-detached } \\
\text { home. }\end{array}$ \\
\hline $\begin{array}{l}\text { Cherry plum } \\
\text { tree }\end{array}$ & $\begin{array}{l}\text { Prunus } \\
\text { cerasifera }\end{array}$ & $10 \%$ dieback, defoliation & 2 & $\begin{array}{l}43.659563^{\circ}, \\
-79.448374^{\circ} \\
\end{array}$ & $\begin{array}{l}\text { In front of } \\
\text { housing }\end{array}$ & $\begin{array}{l}\text { Improved semi-detached } \\
\text { home. }\end{array}$ \\
\hline $\begin{array}{l}\text { Cherry plum } \\
\text { tree }\end{array}$ & $\begin{array}{l}\text { Prunus } \\
\text { cerasifera }\end{array}$ & good condition & 0 & $\begin{array}{l}43.660369^{\circ}, \\
-79.448839^{\circ}\end{array}$ & $\begin{array}{l}\text { In front of } \\
\text { housing }\end{array}$ & $\begin{array}{l}\text { Improved semi-detached } \\
\text { home. }\end{array}$ \\
\hline $\begin{array}{l}\text { Cherry plum } \\
\text { tree }\end{array}$ & $\begin{array}{l}\text { Prunus } \\
\text { cerasifera }\end{array}$ & good condition & 0 & $\begin{array}{l}43.658119^{\circ}, \\
-79.447220^{\circ}\end{array}$ & $\begin{array}{l}\text { In front of } \\
\text { housing }\end{array}$ & Row home. \\
\hline $\begin{array}{l}\text { Cherry plum } \\
\text { tree }\end{array}$ & $\begin{array}{l}\text { Prunus } \\
\text { cerasifera }\end{array}$ & good condition & 0 & $\begin{array}{l}43.658133^{\circ}, \\
-79.447169^{\circ}\end{array}$ & $\begin{array}{l}\text { In front of } \\
\text { housing }\end{array}$ & Row home. \\
\hline $\begin{array}{l}\text { Cherry plum } \\
\text { tree }\end{array}$ & $\begin{array}{l}\text { Prunus } \\
\text { cerasifera }\end{array}$ & good condition & 0 & $\begin{array}{l}43.658142^{\circ}, \\
-79.447111^{\circ}\end{array}$ & $\begin{array}{l}\text { In front of } \\
\text { housing }\end{array}$ & Row home. \\
\hline $\begin{array}{l}\text { Cherry plum } \\
\text { tree }\end{array}$ & $\begin{array}{l}\text { Prunus } \\
\text { cerasifera }\end{array}$ & good condition & 0 & $\begin{array}{l}43.658154^{\circ}, \\
-79.447055^{\circ}\end{array}$ & $\begin{array}{l}\text { In front of } \\
\text { housing }\end{array}$ & Row home. \\
\hline $\begin{array}{l}\text { Cherry plum } \\
\text { tree }\end{array}$ & $\begin{array}{l}\text { Prunus } \\
\text { cerasifera }\end{array}$ & tree lean, defoliation & 2 & $\begin{array}{l}43.658237^{\circ}, \\
-79.447364^{\circ}\end{array}$ & $\begin{array}{l}\text { In front of } \\
\text { housing }\end{array}$ & Row home. \\
\hline $\begin{array}{l}\text { Cherry plum } \\
\text { tree }\end{array}$ & $\begin{array}{l}\text { Prunus } \\
\text { cerasifera }\end{array}$ & good condition & 0 & $\begin{array}{l}43.658238^{\circ}, \\
-79.447362^{\circ}\end{array}$ & $\begin{array}{l}\text { In front of } \\
\text { housing }\end{array}$ & Row home. \\
\hline $\begin{array}{l}\text { Cherry plum } \\
\text { tree }\end{array}$ & $\begin{array}{l}\text { Prunus } \\
\text { cerasifera }\end{array}$ & tree lean, defoliation & 2 & $\begin{array}{l}43.658262^{\circ}, \\
-79.447245^{\circ}\end{array}$ & $\begin{array}{l}\text { In front of } \\
\text { housing }\end{array}$ & Row home. \\
\hline $\begin{array}{l}\text { Cherry plum } \\
\text { tree }\end{array}$ & $\begin{array}{l}\text { Prunus } \\
\text { cerasifera }\end{array}$ & tree lean & 1 & $\begin{array}{l}43.658289^{\circ}, \\
-79.447139^{\circ}\end{array}$ & $\begin{array}{l}\text { In front of } \\
\text { housing }\end{array}$ & Row home. \\
\hline $\begin{array}{l}\text { Cherry plum } \\
\text { tree }\end{array}$ & $\begin{array}{l}\text { Prunus } \\
\text { cerasifera }\end{array}$ & tree lean & 1 & $\begin{array}{l}43.658311^{\circ}, \\
-79.447025^{\circ}\end{array}$ & $\begin{array}{l}\text { In front of } \\
\text { housing }\end{array}$ & Row home. \\
\hline $\begin{array}{l}\text { Cherry plum } \\
\text { tree }\end{array}$ & $\begin{array}{l}\text { Prunus } \\
\text { cerasifera }\end{array}$ & tree lean & 1 & $\begin{array}{l}43.658418^{\circ}, \\
-79.446877^{\circ}\end{array}$ & $\begin{array}{l}\text { In front of } \\
\text { housing }\end{array}$ & Row home. \\
\hline $\begin{array}{l}\text { Cherry plum } \\
\text { tree }\end{array}$ & $\begin{array}{l}\text { Prunus } \\
\text { cerasifera }\end{array}$ & dead branches & 1 & $\begin{array}{l}43.658164^{\circ}, \\
-79.446947^{\circ}\end{array}$ & $\begin{array}{l}\text { In front of } \\
\text { housing }\end{array}$ & Stacked townhome. \\
\hline $\begin{array}{l}\text { Cherry plum } \\
\text { tree }\end{array}$ & $\begin{array}{l}\text { Prunus } \\
\text { cerasifera }\end{array}$ & good condition & 0 & $\begin{array}{l}43.658302^{\circ}, \\
-79.447038^{\circ}\end{array}$ & $\begin{array}{l}\text { In front of } \\
\text { housing }\end{array}$ & Stacked townhome. \\
\hline $\begin{array}{l}\text { Cherry plum } \\
\text { tree }\end{array}$ & $\begin{array}{l}\text { Prunus } \\
\text { cerasifera }\end{array}$ & dead branches & 1 & $\begin{array}{l}43.658308^{\circ}, \\
-79.446985^{\circ}\end{array}$ & $\begin{array}{l}\text { In front of } \\
\text { housing }\end{array}$ & Stacked townhome. \\
\hline $\begin{array}{l}\text { Cherry plum } \\
\text { tree }\end{array}$ & $\begin{array}{l}\text { Prunus } \\
\text { cerasifera }\end{array}$ & $\begin{array}{l}10 \% \text { dieback, cankers on } \\
\text { trunk }\end{array}$ & 2 & $\begin{array}{l}43.658341^{\circ} \\
-79.446877^{\circ}\end{array}$ & $\begin{array}{l}\text { In front of } \\
\text { housing }\end{array}$ & Stacked townhome. \\
\hline $\begin{array}{l}\text { Cherry plum } \\
\text { tree }\end{array}$ & $\begin{array}{l}\text { Prunus } \\
\text { cerasifera }\end{array}$ & cracks, weak branch unions & 2 & $\begin{array}{l}43.658352^{\circ}, \\
-79.446815^{\circ}\end{array}$ & $\begin{array}{l}\text { In front of } \\
\text { housing }\end{array}$ & Stacked townhome. \\
\hline $\begin{array}{l}\text { Cherry plum } \\
\text { tree }\end{array}$ & $\begin{array}{l}\text { Prunus } \\
\text { cerasifera }\end{array}$ & defoliation & 1 & $\begin{array}{l}43.658371^{\circ}, \\
-79.446765^{\circ}\end{array}$ & $\begin{array}{l}\text { In front of } \\
\text { housing }\end{array}$ & Stacked townhome. \\
\hline Chinese Elm & $\begin{array}{l}\text { Ulmus } \\
\text { parvifolia }\end{array}$ & $\begin{array}{l}\text { decaying bark, cankers and } \\
\text { cracks on trunk, defoliation }\end{array}$ & 3 & $\begin{array}{l}43.658729^{\circ} \\
-79.447185^{\circ}\end{array}$ & $\begin{array}{l}\text { In front of } \\
\text { housing }\end{array}$ & $\begin{array}{l}\text { New tree. Improved semi- } \\
\text { detached home. }\end{array}$ \\
\hline Chinese Elm & $\begin{array}{l}\text { Ulmus } \\
\text { parvifolia }\end{array}$ & good condition & 0 & $\begin{array}{l}43.658420^{\circ} \\
-79.449354^{\circ}\end{array}$ & $\begin{array}{l}\text { In front of } \\
\text { housing }\end{array}$ & $\begin{array}{l}\text { Improved semi-detached } \\
\text { home. }\end{array}$ \\
\hline $\begin{array}{l}\text { Choke } \\
\text { Cherry }\end{array}$ & $\begin{array}{l}\text { Prunus } \\
\text { virginiana }\end{array}$ & good condition & 0 & $\begin{array}{l}43.658055^{\circ}, \\
-79.447361^{\circ}\end{array}$ & $\begin{array}{l}\text { In front of } \\
\text { housing }\end{array}$ & New tree. Row home. \\
\hline $\begin{array}{l}\text { Choke } \\
\text { Cherry }\end{array}$ & $\begin{array}{l}\text { Prunus } \\
\text { virginiana }\end{array}$ & good condition & 0 & $\begin{array}{l}43.658217^{\circ}, \\
-79.446655^{\circ}\end{array}$ & $\begin{array}{l}\text { In front of } \\
\text { housing }\end{array}$ & New tree. Row home. \\
\hline $\begin{array}{l}\text { Choke } \\
\text { Cherry }\end{array}$ & $\begin{array}{l}\text { Prunus } \\
\text { virginiana }\end{array}$ & discoloured leaves & 1 & $\begin{array}{l}43.660621^{\circ} \\
-79.448198^{\circ}\end{array}$ & $\begin{array}{l}\text { In front of } \\
\text { housing }\end{array}$ & $\begin{array}{l}\text { Unimproved semi-detached } \\
\text { home. }\end{array}$ \\
\hline $\begin{array}{l}\text { Choke } \\
\text { Cherry }\end{array}$ & $\begin{array}{l}\text { Prunus } \\
\text { virginiana }\end{array}$ & good condition & 0 & $\begin{array}{l}43.659890^{\circ}, \\
-79.447441^{\circ}\end{array}$ & $\begin{array}{l}\text { In front of } \\
\text { housing }\end{array}$ & $\begin{array}{l}\text { Improved semi-detached } \\
\text { home. }\end{array}$ \\
\hline
\end{tabular}




\begin{tabular}{|c|c|c|c|c|c|c|}
\hline $\begin{array}{l}\text { Choke } \\
\text { Cherry }\end{array}$ & $\begin{array}{l}\text { Prunus } \\
\text { virginiana }\end{array}$ & tree lean & 1 & $\begin{array}{l}43.660208^{\circ}, \\
-79.447981^{\circ}\end{array}$ & $\begin{array}{l}\text { In front of } \\
\text { housing }\end{array}$ & $\begin{array}{l}\text { Improved semi-detached } \\
\text { home. }\end{array}$ \\
\hline $\begin{array}{l}\text { Choke } \\
\text { Cherry }\end{array}$ & $\begin{array}{l}\text { Prunus } \\
\text { virginiana }\end{array}$ & cankers on trunk & 1 & $\begin{array}{l}43.660438^{\circ}, \\
-79.448899^{\circ} \\
\end{array}$ & $\begin{array}{l}\text { In front of } \\
\text { housing }\end{array}$ & $\begin{array}{l}\text { Improved semi-detached } \\
\text { home. }\end{array}$ \\
\hline $\begin{array}{l}\text { Choke } \\
\text { Cherry }\end{array}$ & $\begin{array}{l}\text { Prunus } \\
\text { virginiana }\end{array}$ & peeling bark & 1 & $\begin{array}{l}43.660476^{\circ}, \\
-79.448896^{\circ}\end{array}$ & $\begin{array}{l}\text { In front of } \\
\text { housing }\end{array}$ & $\begin{array}{l}\text { Improved semi-detached } \\
\text { home. }\end{array}$ \\
\hline $\begin{array}{l}\text { Choke } \\
\text { Cherry }\end{array}$ & $\begin{array}{l}\text { Prunus } \\
\text { virginiana }\end{array}$ & tree lean & 1 & $\begin{array}{l}43.660559^{\circ} \\
-79.448143^{\circ}\end{array}$ & $\begin{array}{l}\text { In front of } \\
\text { housing }\end{array}$ & $\begin{array}{l}\text { Improved semi-detached } \\
\text { home. }\end{array}$ \\
\hline $\begin{array}{l}\text { Common } \\
\text { Apple }\end{array}$ & Malus pumila & tree lean, cracks on trunk & 2 & $\begin{array}{l}43.659546^{\circ} \\
-79.450112^{\circ}\end{array}$ & $\begin{array}{l}\text { In front of } \\
\text { housing }\end{array}$ & $\begin{array}{l}\text { Unimproved semi-detached } \\
\text { home. }\end{array}$ \\
\hline $\begin{array}{l}\text { Common } \\
\text { Apple }\end{array}$ & Malus pumila & $\begin{array}{l}\text { defoliation, weak branch } \\
\text { unions }\end{array}$ & 2 & $\begin{array}{l}43.658769^{\circ}, \\
-79.448234^{\circ}\end{array}$ & $\begin{array}{l}\text { In front of } \\
\text { housing }\end{array}$ & $\begin{array}{l}\text { Improved semi-detached } \\
\text { home. }\end{array}$ \\
\hline $\begin{array}{l}\text { Common } \\
\text { PawPaw }\end{array}$ & Asimina tribola & good condition & 0 & $\begin{array}{l}43.659045^{\circ}, \\
-79.448470^{\circ}\end{array}$ & $\begin{array}{l}\text { In front of } \\
\text { housing }\end{array}$ & $\begin{array}{l}\text { New tree. Improved semi- } \\
\text { detached home. }\end{array}$ \\
\hline $\begin{array}{l}\text { Corkscrew } \\
\text { Willow }\end{array}$ & $\begin{array}{l}\text { Salix } \\
\text { matsudana }\end{array}$ & good condition & 0 & $\begin{array}{l}43.660503^{\circ}, \\
-79.452391^{\circ} \\
\end{array}$ & $\begin{array}{l}\text { In front of } \\
\text { housing }\end{array}$ & Low-rise apartment. \\
\hline Douglas Fir & $\begin{array}{l}\text { Pseudotsuga } \\
\text { menziesii }\end{array}$ & tree lean, dead branches & 2 & $\begin{array}{l}43.657331^{\circ}, \\
-79.449317^{\circ}\end{array}$ & $\begin{array}{l}\text { In front of } \\
\text { housing }\end{array}$ & Low-rise apartment. \\
\hline Douglas Fir & $\begin{array}{l}\text { Pseudotsuga } \\
\text { menziesii }\end{array}$ & tree lean & 1 & $\begin{array}{l}43.657340^{\circ}, \\
-79.449300^{\circ}\end{array}$ & $\begin{array}{l}\text { In front of } \\
\text { housing }\end{array}$ & Low-rise apartment. \\
\hline Douglas Fir & $\begin{array}{l}\text { Pseudotsuga } \\
\text { menziesii }\end{array}$ & tree lean, dead branches & 2 & $\begin{array}{l}43.657348^{\circ}, \\
-79.449264^{\circ}\end{array}$ & $\begin{array}{l}\text { In front of } \\
\text { housing }\end{array}$ & $\begin{array}{l}\text { New tree. Low-rise } \\
\text { apartment. }\end{array}$ \\
\hline Douglas Fir & $\begin{array}{l}\text { Pseudotsuga } \\
\text { menziesii }\end{array}$ & tree lean, dead branches & 2 & $\begin{array}{l}43.657353^{\circ}, \\
-79.449229^{\circ}\end{array}$ & $\begin{array}{l}\text { In front of } \\
\text { housing }\end{array}$ & $\begin{array}{l}\text { New tree. Low-rise } \\
\text { apartment. }\end{array}$ \\
\hline Douglas Fir & $\begin{array}{l}\text { Pseudotsuga } \\
\text { menziesii }\end{array}$ & good condition & 0 & $\begin{array}{l}43.657978^{\circ} \\
-79.450159^{\circ}\end{array}$ & $\begin{array}{l}\text { In front of } \\
\text { housing }\end{array}$ & $\begin{array}{l}\text { New tree. Stacked } \\
\text { townhome. }\end{array}$ \\
\hline Douglas Fir & $\begin{array}{l}\text { Pseudotsuga } \\
\text { menziesii }\end{array}$ & dead/broken branches & 2 & $\begin{array}{l}43.658969^{\circ}, \\
-79.449583^{\circ}\end{array}$ & $\begin{array}{l}\text { In front of } \\
\text { housing }\end{array}$ & $\begin{array}{l}\text { Unimproved semi-detached } \\
\text { home. }\end{array}$ \\
\hline $\begin{array}{l}\text { Eastern } \\
\text { White Cedar }\end{array}$ & $\begin{array}{l}\text { Thuja } \\
\text { occidentalis }\end{array}$ & good condition & 0 & $\begin{array}{l}43.660410^{\circ}, \\
-79.452348^{\circ}\end{array}$ & $\begin{array}{l}\text { In front of } \\
\text { housing }\end{array}$ & $\begin{array}{l}\text { New tree. Low-rise } \\
\text { apartment. }\end{array}$ \\
\hline $\begin{array}{l}\text { Eastern } \\
\text { White Cedar }\end{array}$ & $\begin{array}{l}\text { Thuja } \\
\text { occidentalis }\end{array}$ & tree lean & 1 & $\begin{array}{l}43.658453^{\circ}, \\
-79.448350^{\circ}\end{array}$ & $\begin{array}{l}\text { In front of } \\
\text { housing }\end{array}$ & $\begin{array}{l}\text { New tree. Unimproved semi- } \\
\text { detached home. }\end{array}$ \\
\hline $\begin{array}{l}\text { Eastern } \\
\text { White Cedar }\end{array}$ & $\begin{array}{l}\text { Thuja } \\
\text { occidentalis }\end{array}$ & tree lean & 1 & $\begin{array}{l}43.661003^{\circ}, \\
-79.448055^{\circ}\end{array}$ & $\begin{array}{l}\text { In front of } \\
\text { housing }\end{array}$ & $\begin{array}{l}\text { New tree. Unimproved semi- } \\
\text { detached home. }\end{array}$ \\
\hline $\begin{array}{l}\text { Eastern } \\
\text { White Cedar }\end{array}$ & $\begin{array}{l}\text { Thuja } \\
\text { occidentalis }\end{array}$ & good condition & 0 & $\begin{array}{l}43.657619^{\circ}, \\
-79.449011^{\circ}\end{array}$ & $\begin{array}{l}\text { In front of } \\
\text { housing }\end{array}$ & $\begin{array}{l}\text { New tree. Improved semi- } \\
\text { detached home. }\end{array}$ \\
\hline $\begin{array}{l}\text { Eastern } \\
\text { White Cedar }\end{array}$ & $\begin{array}{l}\text { Thuja } \\
\text { occidentalis }\end{array}$ & good condition & 0 & $\begin{array}{l}43.658387^{\circ}, \\
-79.448314^{\circ}\end{array}$ & $\begin{array}{l}\text { In front of } \\
\text { housing }\end{array}$ & $\begin{array}{l}\text { New tree. Improved semi- } \\
\text { detached home. }\end{array}$ \\
\hline $\begin{array}{l}\text { Eastern } \\
\text { White Cedar }\end{array}$ & $\begin{array}{l}\text { Thuja } \\
\text { occidentalis }\end{array}$ & good condition & 0 & $\begin{array}{l}43.658439^{\circ}, \\
-79.448077^{\circ}\end{array}$ & $\begin{array}{l}\text { In front of } \\
\text { housing }\end{array}$ & $\begin{array}{l}\text { New tree. Improved semi- } \\
\text { detached home. }\end{array}$ \\
\hline $\begin{array}{l}\text { Eastern } \\
\text { White Cedar }\end{array}$ & $\begin{array}{l}\text { Thuja } \\
\text { occidentalis }\end{array}$ & good condition & 0 & $\begin{array}{l}43.658447^{\circ}, \\
-79.448082^{\circ}\end{array}$ & $\begin{array}{l}\text { In front of } \\
\text { housing }\end{array}$ & $\begin{array}{l}\text { New tree. Improved semi- } \\
\text { detached home. }\end{array}$ \\
\hline $\begin{array}{l}\text { Eastern } \\
\text { White Cedar }\end{array}$ & $\begin{array}{l}\text { Thuja } \\
\text { occidentalis }\end{array}$ & good condition & 0 & $\begin{array}{l}43.658457^{\circ}, \\
-79.447084^{\circ}\end{array}$ & $\begin{array}{l}\text { In front of } \\
\text { housing }\end{array}$ & $\begin{array}{l}\text { New tree. Improved semi- } \\
\text { detached home. }\end{array}$ \\
\hline $\begin{array}{l}\text { Eastern } \\
\text { White Cedar }\end{array}$ & $\begin{array}{l}\text { Thuja } \\
\text { occidentalis }\end{array}$ & good condition & 0 & $\begin{array}{l}43.658472^{\circ}, \\
-79.447099^{\circ} \\
\end{array}$ & $\begin{array}{l}\text { In front of } \\
\text { housing }\end{array}$ & $\begin{array}{l}\text { New tree. Improved semi- } \\
\text { detached home. }\end{array}$ \\
\hline $\begin{array}{l}\text { Eastern } \\
\text { White Cedar }\end{array}$ & $\begin{array}{l}\text { Thuja } \\
\text { occidentalis }\end{array}$ & good condition & 0 & $\begin{array}{l}43.658501^{\circ}, \\
-79.448116^{\circ}\end{array}$ & $\begin{array}{l}\text { In front of } \\
\text { housing }\end{array}$ & $\begin{array}{l}\text { New tree. Improved semi- } \\
\text { detached home. }\end{array}$ \\
\hline $\begin{array}{l}\text { Eastern } \\
\text { White Cedar }\end{array}$ & $\begin{array}{l}\text { Thuja } \\
\text { occidentalis }\end{array}$ & good condition & 1 & $\begin{array}{l}43.658502^{\circ}, \\
-79.447301^{\circ}\end{array}$ & $\begin{array}{l}\text { In front of } \\
\text { housing }\end{array}$ & $\begin{array}{l}\text { New tree. Improved semi- } \\
\text { detached home. }\end{array}$ \\
\hline $\begin{array}{l}\text { Eastern } \\
\text { White Cedar }\end{array}$ & $\begin{array}{l}\text { Thuja } \\
\text { occidentalis }\end{array}$ & good condition & 0 & $\begin{array}{l}43.658560^{\circ}, \\
-79.448386^{\circ}\end{array}$ & $\begin{array}{l}\text { In front of } \\
\text { housing }\end{array}$ & $\begin{array}{l}\text { New tree. Improved semi- } \\
\text { detached home. }\end{array}$ \\
\hline $\begin{array}{l}\text { Eastern } \\
\text { White Cedar }\end{array}$ & $\begin{array}{l}\text { Thuja } \\
\text { occidentalis }\end{array}$ & good condition & 0 & $\begin{array}{l}43.658567^{\circ} \\
-79.448386^{\circ}\end{array}$ & $\begin{array}{l}\text { In front of } \\
\text { housing }\end{array}$ & $\begin{array}{l}\text { New tree. Improved semi- } \\
\text { detached home. }\end{array}$ \\
\hline $\begin{array}{l}\text { Eastern } \\
\text { White Cedar }\end{array}$ & $\begin{array}{l}\text { Thuja } \\
\text { occidentalis }\end{array}$ & good condition & 0 & $\begin{array}{l}43.658572^{\circ}, \\
-79.448390^{\circ}\end{array}$ & $\begin{array}{l}\text { In front of } \\
\text { housing }\end{array}$ & $\begin{array}{l}\text { New tree. Improved semi- } \\
\text { detached home. }\end{array}$ \\
\hline $\begin{array}{l}\text { Eastern } \\
\text { White Cedar }\end{array}$ & $\begin{array}{l}\text { Thuja } \\
\text { occidentalis }\end{array}$ & good condition & 0 & $\begin{array}{l}43.658579^{\circ}, \\
-79.448393^{\circ} \\
\end{array}$ & $\begin{array}{l}\text { In front of } \\
\text { housing }\end{array}$ & $\begin{array}{l}\text { New tree. Improved semi- } \\
\text { detached home. }\end{array}$ \\
\hline $\begin{array}{l}\text { Eastern } \\
\text { White Cedar }\end{array}$ & $\begin{array}{l}\text { Thuja } \\
\text { occidentalis }\end{array}$ & good condition & 0 & $\begin{array}{l}43.658678^{\circ}, \\
-79.448448^{\circ}\end{array}$ & $\begin{array}{l}\text { In front of } \\
\text { housing }\end{array}$ & $\begin{array}{l}\text { New tree. Improved semi- } \\
\text { detached home. }\end{array}$ \\
\hline $\begin{array}{l}\text { Eastern } \\
\text { White Cedar }\end{array}$ & $\begin{array}{l}\text { Thuja } \\
\text { occidentalis }\end{array}$ & good condition & 0 & $\begin{array}{l}43.658693^{\circ}, \\
-79.448454^{\circ}\end{array}$ & $\begin{array}{l}\text { In front of } \\
\text { housing }\end{array}$ & $\begin{array}{l}\text { New tree. Improved semi- } \\
\text { detached home. }\end{array}$ \\
\hline $\begin{array}{l}\text { Eastern } \\
\text { White Cedar }\end{array}$ & $\begin{array}{l}\text { Thuja } \\
\text { occidentalis }\end{array}$ & good condition & 0 & $\begin{array}{l}43.658707^{\circ}, \\
-79.448216^{\circ}\end{array}$ & $\begin{array}{l}\text { In front of } \\
\text { housing }\end{array}$ & $\begin{array}{l}\text { New tree. Improved semi- } \\
\text { detached home. }\end{array}$ \\
\hline $\begin{array}{l}\text { Eastern } \\
\text { White Cedar }\end{array}$ & $\begin{array}{l}\text { Thuja } \\
\text { occidentalis }\end{array}$ & good condition & 0 & $\begin{array}{l}43.658805^{\circ}, \\
-79.448267^{\circ}\end{array}$ & $\begin{array}{l}\text { In front of } \\
\text { housing }\end{array}$ & $\begin{array}{l}\text { New tree. Improved semi- } \\
\text { detached home. }\end{array}$ \\
\hline $\begin{array}{l}\text { Eastern } \\
\text { White Cedar }\end{array}$ & $\begin{array}{l}\text { Thuja } \\
\text { occidentalis }\end{array}$ & $50 \%$ dieback & 2 & $\begin{array}{l}43.658829^{\circ} \\
-79.448276^{\circ}\end{array}$ & $\begin{array}{l}\text { In front of } \\
\text { housing }\end{array}$ & $\begin{array}{l}\text { New tree. Improved semi- } \\
\text { detached home. }\end{array}$ \\
\hline
\end{tabular}




\begin{tabular}{|c|c|c|c|c|c|c|}
\hline $\begin{array}{l}\text { Eastern } \\
\text { White Cedar }\end{array}$ & $\begin{array}{l}\text { Thuja } \\
\text { occidentalis }\end{array}$ & good condition & 0 & $\begin{array}{l}43.658926^{\circ}, \\
-79.449603^{\circ} \\
\end{array}$ & $\begin{array}{l}\text { In front of } \\
\text { housing }\end{array}$ & $\begin{array}{l}\text { New tree. Improved semi- } \\
\text { detached home. }\end{array}$ \\
\hline $\begin{array}{l}\text { Eastern } \\
\text { White Cedar }\end{array}$ & $\begin{array}{l}\text { Thuja } \\
\text { occidentalis }\end{array}$ & good condition & 0 & $\begin{array}{l}43.658933^{\circ}, \\
-79.449567^{\circ}\end{array}$ & $\begin{array}{l}\text { In front of } \\
\text { housing }\end{array}$ & $\begin{array}{l}\text { New tree. Improved semi- } \\
\text { detached home. }\end{array}$ \\
\hline $\begin{array}{l}\text { Eastern } \\
\text { White Cedar }\end{array}$ & $\begin{array}{l}\text { Thuja } \\
\text { occidentalis }\end{array}$ & tree lean, defoliation & 2 & $\begin{array}{l}43.659083^{\circ}, \\
-79.448365^{\circ}\end{array}$ & $\begin{array}{l}\text { In front of } \\
\text { housing }\end{array}$ & $\begin{array}{l}\text { New tree. Improved semi- } \\
\text { detached home. }\end{array}$ \\
\hline $\begin{array}{l}\text { Eastern } \\
\text { White Cedar }\end{array}$ & $\begin{array}{l}\text { Thuja } \\
\text { occidentalis }\end{array}$ & good condition & 0 & $\begin{array}{l}43.659147^{\circ} \\
-79.447598^{\circ}\end{array}$ & $\begin{array}{l}\text { In front of } \\
\text { housing }\end{array}$ & $\begin{array}{l}\text { New tree. Improved semi- } \\
\text { detached home. }\end{array}$ \\
\hline $\begin{array}{l}\text { Eastern } \\
\text { White Cedar }\end{array}$ & $\begin{array}{l}\text { Thuja } \\
\text { occidentalis }\end{array}$ & good condition & 0 & $\begin{array}{l}43.659152^{\circ}, \\
-79.447600^{\circ}\end{array}$ & $\begin{array}{l}\text { In front of } \\
\text { housing }\end{array}$ & $\begin{array}{l}\text { New tree. Improved semi- } \\
\text { detached home. }\end{array}$ \\
\hline $\begin{array}{l}\text { Eastern } \\
\text { White Cedar }\end{array}$ & $\begin{array}{l}\text { Thuja } \\
\text { occidentalis }\end{array}$ & good condition & 0 & $\begin{array}{l}43.659234^{\circ} \\
-79.447625^{\circ}\end{array}$ & $\begin{array}{l}\text { In front of } \\
\text { housing }\end{array}$ & $\begin{array}{l}\text { New tree. Improved semi- } \\
\text { detached home. }\end{array}$ \\
\hline $\begin{array}{l}\text { Eastern } \\
\text { White Cedar }\end{array}$ & $\begin{array}{l}\text { Thuja } \\
\text { occidentalis }\end{array}$ & good condition & 0 & $\begin{array}{l}43.659413^{\circ}, \\
-79.447687^{\circ}\end{array}$ & $\begin{array}{l}\text { In front of } \\
\text { housing }\end{array}$ & $\begin{array}{l}\text { New tree. Improved semi- } \\
\text { detached home. }\end{array}$ \\
\hline $\begin{array}{l}\text { Eastern } \\
\text { White Cedar }\end{array}$ & $\begin{array}{l}\text { Thuja } \\
\text { occidentalis }\end{array}$ & good condition & 0 & $\begin{array}{l}43.659483^{\circ}, \\
-79.447713^{\circ}\end{array}$ & $\begin{array}{l}\text { In front of } \\
\text { housing }\end{array}$ & $\begin{array}{l}\text { New tree. Improved semi- } \\
\text { detached home. }\end{array}$ \\
\hline $\begin{array}{l}\text { Eastern } \\
\text { White Cedar }\end{array}$ & $\begin{array}{l}\text { Thuja } \\
\text { occidentalis }\end{array}$ & good condition & 0 & $\begin{array}{l}43.659498^{\circ}, \\
-79.447719^{\circ}\end{array}$ & $\begin{array}{l}\text { In front of } \\
\text { housing }\end{array}$ & $\begin{array}{l}\text { New tree. Improved semi- } \\
\text { detached home. }\end{array}$ \\
\hline $\begin{array}{l}\text { Eastern } \\
\text { White Cedar }\end{array}$ & $\begin{array}{l}\text { Thuja } \\
\text { occidentalis }\end{array}$ & good condition & 0 & $\begin{array}{l}43.659511^{\circ}, \\
-79.447727^{\circ}\end{array}$ & $\begin{array}{l}\text { In front of } \\
\text { housing }\end{array}$ & $\begin{array}{l}\text { New tree. Improved semi- } \\
\text { detached home. }\end{array}$ \\
\hline $\begin{array}{l}\text { Eastern } \\
\text { White Cedar }\end{array}$ & $\begin{array}{l}\text { Thuja } \\
\text { occidentalis }\end{array}$ & good condition & 0 & $\begin{array}{l}43.659774^{\circ}, \\
-79.446802^{\circ}\end{array}$ & $\begin{array}{l}\text { In front of } \\
\text { housing }\end{array}$ & $\begin{array}{l}\text { New tree. Improved semi- } \\
\text { detached home. }\end{array}$ \\
\hline $\begin{array}{l}\text { Eastern } \\
\text { White Cedar }\end{array}$ & $\begin{array}{l}\text { Thuja } \\
\text { occidentalis }\end{array}$ & good condition & 0 & $\begin{array}{l}43.659774^{\circ}, \\
-79.449028^{\circ}\end{array}$ & $\begin{array}{l}\text { In front of } \\
\text { housing }\end{array}$ & $\begin{array}{l}\text { New tree. Improved semi- } \\
\text { detached home. }\end{array}$ \\
\hline $\begin{array}{l}\text { Eastern } \\
\text { White Cedar }\end{array}$ & $\begin{array}{l}\text { Thuja } \\
\text { occidentalis }\end{array}$ & good condition & 0 & $\begin{array}{l}43.659776^{\circ}, \\
-79.449023^{\circ}\end{array}$ & $\begin{array}{l}\text { In front of } \\
\text { housing }\end{array}$ & $\begin{array}{l}\text { New tree. Improved semi- } \\
\text { detached home. }\end{array}$ \\
\hline $\begin{array}{l}\text { Eastern } \\
\text { White Cedar }\end{array}$ & $\begin{array}{l}\text { Thuja } \\
\text { occidentalis }\end{array}$ & good condition & 0 & $\begin{array}{l}43.659777^{\circ}, \\
-79.449019^{\circ}\end{array}$ & $\begin{array}{l}\text { In front of } \\
\text { housing }\end{array}$ & $\begin{array}{l}\text { New tree. Improved semi- } \\
\text { detached home. }\end{array}$ \\
\hline $\begin{array}{l}\text { Eastern } \\
\text { White Cedar }\end{array}$ & $\begin{array}{l}\text { Thuja } \\
\text { occidentalis }\end{array}$ & good condition & 0 & $\begin{array}{l}43.659778^{\circ}, \\
-79.449014^{\circ}\end{array}$ & $\begin{array}{l}\text { In front of } \\
\text { housing }\end{array}$ & $\begin{array}{l}\text { New tree. Improved semi- } \\
\text { detached home. }\end{array}$ \\
\hline $\begin{array}{l}\text { Eastern } \\
\text { White Cedar }\end{array}$ & $\begin{array}{l}\text { Thuja } \\
\text { occidentalis }\end{array}$ & tree lean & 1 & $\begin{array}{l}43.659779^{\circ}, \\
-79.449011^{\circ} \\
\end{array}$ & $\begin{array}{l}\text { In front of } \\
\text { housing }\end{array}$ & $\begin{array}{l}\text { New tree. Improved semi- } \\
\text { detached home. }\end{array}$ \\
\hline $\begin{array}{l}\text { Eastern } \\
\text { White Cedar }\end{array}$ & $\begin{array}{l}\text { Thuja } \\
\text { occidentalis }\end{array}$ & good condition & 0 & $\begin{array}{l}43.659780^{\circ}, \\
-79.449002^{\circ}\end{array}$ & $\begin{array}{l}\text { In front of } \\
\text { housing }\end{array}$ & $\begin{array}{l}\text { New tree. Improved semi- } \\
\text { detached home. }\end{array}$ \\
\hline $\begin{array}{l}\text { Eastern } \\
\text { White Cedar }\end{array}$ & $\begin{array}{l}\text { Thuja } \\
\text { occidentalis }\end{array}$ & good condition & 0 & $\begin{array}{l}43.659780^{\circ}, \\
-79.449006^{\circ}\end{array}$ & $\begin{array}{l}\text { In front of } \\
\text { housing }\end{array}$ & $\begin{array}{l}\text { New tree. Improved semi- } \\
\text { detached home. }\end{array}$ \\
\hline $\begin{array}{l}\text { Eastern } \\
\text { White Cedar }\end{array}$ & $\begin{array}{l}\text { Thuja } \\
\text { occidentalis }\end{array}$ & good condition & 0 & $\begin{array}{l}43.659782^{\circ}, \\
-79.448996^{\circ}\end{array}$ & $\begin{array}{l}\text { In front of } \\
\text { housing }\end{array}$ & $\begin{array}{l}\text { New tree. Improved semi- } \\
\text { detached home. }\end{array}$ \\
\hline $\begin{array}{l}\text { Eastern } \\
\text { White Cedar }\end{array}$ & $\begin{array}{l}\text { Thuja } \\
\text { occidentalis }\end{array}$ & good condition & 0 & $\begin{array}{l}43.659783^{\circ}, \\
-79.448989^{\circ}\end{array}$ & $\begin{array}{l}\text { In front of } \\
\text { housing }\end{array}$ & $\begin{array}{l}\text { New tree. Improved semi- } \\
\text { detached home. }\end{array}$ \\
\hline $\begin{array}{l}\text { Eastern } \\
\text { White Cedar }\end{array}$ & $\begin{array}{l}\text { Thuja } \\
\text { occidentalis }\end{array}$ & good condition & 0 & $\begin{array}{l}43.659785^{\circ}, \\
-79.448984^{\circ}\end{array}$ & $\begin{array}{l}\text { In front of } \\
\text { housing }\end{array}$ & $\begin{array}{l}\text { New tree. Improved semi- } \\
\text { detached home. }\end{array}$ \\
\hline $\begin{array}{l}\text { Eastern } \\
\text { White Cedar }\end{array}$ & $\begin{array}{l}\text { Thuja } \\
\text { occidentalis }\end{array}$ & good condition & 0 & $\begin{array}{l}43.659787^{\circ}, \\
-79.448976^{\circ}\end{array}$ & $\begin{array}{l}\text { In front of } \\
\text { housing }\end{array}$ & $\begin{array}{l}\text { New tree. Improved semi- } \\
\text { detached home. }\end{array}$ \\
\hline $\begin{array}{l}\text { Eastern } \\
\text { White Cedar }\end{array}$ & $\begin{array}{l}\text { Thuja } \\
\text { occidentalis }\end{array}$ & $\begin{array}{l}\text { defoliation, discoloured } \\
\text { leaves }\end{array}$ & 2 & $\begin{array}{l}43.659792^{\circ}, \\
-79.448979^{\circ}\end{array}$ & $\begin{array}{l}\text { In front of } \\
\text { housing }\end{array}$ & $\begin{array}{l}\text { New tree. Improved semi- } \\
\text { detached home. }\end{array}$ \\
\hline $\begin{array}{l}\text { Eastern } \\
\text { White Cedar }\end{array}$ & $\begin{array}{l}\text { Thuja } \\
\text { occidentalis }\end{array}$ & defoliation & 1 & $\begin{array}{l}43.659798^{\circ}, \\
-79.448970^{\circ}\end{array}$ & $\begin{array}{l}\text { In front of } \\
\text { housing }\end{array}$ & $\begin{array}{l}\text { New tree. Improved semi- } \\
\text { detached home. }\end{array}$ \\
\hline $\begin{array}{l}\text { Eastern } \\
\text { White Cedar }\end{array}$ & $\begin{array}{l}\text { Thuja } \\
\text { occidentalis }\end{array}$ & good condition & 0 & $\begin{array}{l}43.659800^{\circ}, \\
-79.448955^{\circ}\end{array}$ & $\begin{array}{l}\text { In front of } \\
\text { housing }\end{array}$ & $\begin{array}{l}\text { New tree. Improved semi- } \\
\text { detached home. }\end{array}$ \\
\hline $\begin{array}{l}\text { Eastern } \\
\text { White Cedar }\end{array}$ & $\begin{array}{l}\text { Thuja } \\
\text { occidentalis }\end{array}$ & good condition & 0 & $\begin{array}{l}43.659800^{\circ}, \\
-79.448959^{\circ}\end{array}$ & $\begin{array}{l}\text { In front of } \\
\text { housing }\end{array}$ & $\begin{array}{l}\text { New tree. Improved semi- } \\
\text { detached home. }\end{array}$ \\
\hline $\begin{array}{l}\text { Eastern } \\
\text { White Cedar }\end{array}$ & $\begin{array}{l}\text { Thuja } \\
\text { occidentalis }\end{array}$ & good condition & 0 & $\begin{array}{l}43.659802^{\circ}, \\
-79.448943^{\circ}\end{array}$ & $\begin{array}{l}\text { In front of } \\
\text { housing }\end{array}$ & $\begin{array}{l}\text { New tree. Improved semi- } \\
\text { detached home. }\end{array}$ \\
\hline $\begin{array}{l}\text { Eastern } \\
\text { White Cedar }\end{array}$ & $\begin{array}{l}\text { Thuja } \\
\text { occidentalis }\end{array}$ & good condition & 0 & $\begin{array}{l}43.659802^{\circ}, \\
-79.448947^{\circ}\end{array}$ & $\begin{array}{l}\text { In front of } \\
\text { housing }\end{array}$ & $\begin{array}{l}\text { New tree. Improved semi- } \\
\text { detached home. }\end{array}$ \\
\hline $\begin{array}{l}\text { Eastern } \\
\text { White Cedar }\end{array}$ & $\begin{array}{l}\text { Thuja } \\
\text { occidentalis }\end{array}$ & defoliation & 1 & $\begin{array}{l}43.659802^{\circ}, \\
-79.448951^{\circ}\end{array}$ & $\begin{array}{l}\text { In front of } \\
\text { housing }\end{array}$ & $\begin{array}{l}\text { New tree. Improved semi- } \\
\text { detached home. }\end{array}$ \\
\hline $\begin{array}{l}\text { Eastern } \\
\text { White Cedar }\end{array}$ & $\begin{array}{l}\text { Thuja } \\
\text { occidentalis }\end{array}$ & good condition & 0 & $\begin{array}{l}43.659804^{\circ}, \\
-79.448938^{\circ}\end{array}$ & $\begin{array}{l}\text { In front of } \\
\text { housing }\end{array}$ & $\begin{array}{l}\text { New tree. Improved semi- } \\
\text { detached home. }\end{array}$ \\
\hline $\begin{array}{l}\text { Eastern } \\
\text { White Cedar }\end{array}$ & $\begin{array}{l}\text { Thuja } \\
\text { occidentalis }\end{array}$ & defoliation & 1 & $\begin{array}{l}43.659806^{\circ}, \\
-79.448926^{\circ}\end{array}$ & $\begin{array}{l}\text { In front of } \\
\text { housing }\end{array}$ & $\begin{array}{l}\text { New tree. Improved semi- } \\
\text { detached home. }\end{array}$ \\
\hline $\begin{array}{l}\text { Eastern } \\
\text { White Cedar }\end{array}$ & $\begin{array}{l}\text { Thuja } \\
\text { occidentalis }\end{array}$ & good condition & 0 & $\begin{array}{l}43.659807^{\circ}, \\
-79.448922^{\circ}\end{array}$ & $\begin{array}{l}\text { In front of } \\
\text { housing }\end{array}$ & $\begin{array}{l}\text { New tree. Improved semi- } \\
\text { detached home. }\end{array}$ \\
\hline $\begin{array}{l}\text { Eastern } \\
\text { White Cedar }\end{array}$ & $\begin{array}{l}\text { Thuja } \\
\text { occidentalis }\end{array}$ & good condition & 0 & $\begin{array}{l}43.659808^{\circ}, \\
-79.448918^{\circ}\end{array}$ & $\begin{array}{l}\text { In front of } \\
\text { housing }\end{array}$ & $\begin{array}{l}\text { New tree. Improved semi- } \\
\text { detached home. }\end{array}$ \\
\hline $\begin{array}{l}\text { Eastern } \\
\text { White Cedar }\end{array}$ & $\begin{array}{l}\text { Thuja } \\
\text { occidentalis }\end{array}$ & defoliation & 1 & $\begin{array}{l}43.659810^{\circ} \\
-79.448909^{\circ}\end{array}$ & $\begin{array}{l}\text { In front of } \\
\text { housing }\end{array}$ & $\begin{array}{l}\text { New tree. Improved semi- } \\
\text { detached home. }\end{array}$ \\
\hline
\end{tabular}




\begin{tabular}{|c|c|c|c|c|c|c|}
\hline $\begin{array}{l}\text { Eastern } \\
\text { White Cedar }\end{array}$ & $\begin{array}{l}\text { Thuja } \\
\text { occidentalis }\end{array}$ & good condition & 0 & $\begin{array}{l}43.659811^{\circ}, \\
-79.448901^{\circ}\end{array}$ & $\begin{array}{l}\text { In front of } \\
\text { housing }\end{array}$ & $\begin{array}{l}\text { New tree. Improved semi- } \\
\text { detached home. }\end{array}$ \\
\hline $\begin{array}{l}\text { Eastern } \\
\text { White Cedar }\end{array}$ & $\begin{array}{l}\text { Thuja } \\
\text { occidentalis }\end{array}$ & defoliation & 1 & $\begin{array}{l}43.659811^{\circ}, \\
-79.448905^{\circ}\end{array}$ & $\begin{array}{l}\text { In front of } \\
\text { housing }\end{array}$ & $\begin{array}{l}\text { New tree. Improved semi- } \\
\text { detached home. }\end{array}$ \\
\hline $\begin{array}{l}\text { Eastern } \\
\text { White Cedar }\end{array}$ & $\begin{array}{l}\text { Thuja } \\
\text { occidentalis }\end{array}$ & defoliation & 1 & $\begin{array}{l}43.659812^{\circ}, \\
-79.448898^{\circ}\end{array}$ & $\begin{array}{l}\text { In front of } \\
\text { housing }\end{array}$ & $\begin{array}{l}\text { New tree. Improved semi- } \\
\text { detached home. }\end{array}$ \\
\hline $\begin{array}{l}\text { Eastern } \\
\text { White Cedar }\end{array}$ & $\begin{array}{l}\text { Thuja } \\
\text { occidentalis }\end{array}$ & good condition & 0 & $\begin{array}{l}43.659829^{\circ}, \\
-79.448890^{\circ}\end{array}$ & $\begin{array}{l}\text { In front of } \\
\text { housing }\end{array}$ & $\begin{array}{l}\text { New tree. Improved semi- } \\
\text { detached home. }\end{array}$ \\
\hline $\begin{array}{l}\text { Eastern } \\
\text { White Cedar }\end{array}$ & $\begin{array}{l}\text { Thuja } \\
\text { occidentalis }\end{array}$ & good condition & 0 & $\begin{array}{l}43.659840^{\circ}, \\
-79.446818^{\circ}\end{array}$ & $\begin{array}{l}\text { In front of } \\
\text { housing }\end{array}$ & $\begin{array}{l}\text { New tree. Improved semi- } \\
\text { detached home. }\end{array}$ \\
\hline $\begin{array}{l}\text { Eastern } \\
\text { White Cedar }\end{array}$ & $\begin{array}{l}\text { Thuja } \\
\text { occidentalis }\end{array}$ & $\begin{array}{l}\text { defoliation, discoloured } \\
\text { leaves }\end{array}$ & 2 & $\begin{array}{l}43.659847^{\circ} \\
-79.448876^{\circ}\end{array}$ & $\begin{array}{l}\text { In front of } \\
\text { housing }\end{array}$ & $\begin{array}{l}\text { New tree. Improved semi- } \\
\text { detached home. }\end{array}$ \\
\hline $\begin{array}{l}\text { Eastern } \\
\text { White Cedar }\end{array}$ & $\begin{array}{l}\text { Thuja } \\
\text { occidentalis }\end{array}$ & $\begin{array}{l}\text { defoliation, discoloured } \\
\text { leaves }\end{array}$ & 2 & $\begin{array}{l}43.659852^{\circ}, \\
-79.448877^{\circ}\end{array}$ & $\begin{array}{l}\text { In front of } \\
\text { housing }\end{array}$ & $\begin{array}{l}\text { New tree. Improved semi- } \\
\text { detached home. }\end{array}$ \\
\hline $\begin{array}{l}\text { Eastern } \\
\text { White Cedar }\end{array}$ & $\begin{array}{l}\text { Thuja } \\
\text { occidentalis }\end{array}$ & good condition & 0 & $\begin{array}{l}43.659856^{\circ}, \\
-79.448878^{\circ}\end{array}$ & $\begin{array}{l}\text { In front of } \\
\text { housing }\end{array}$ & $\begin{array}{l}\text { New tree. Improved semi- } \\
\text { detached home. }\end{array}$ \\
\hline $\begin{array}{l}\text { Eastern } \\
\text { White Cedar }\end{array}$ & $\begin{array}{l}\text { Thuja } \\
\text { occidentalis }\end{array}$ & tree lean, defoliation & 2 & $\begin{array}{l}43.659858^{\circ}, \\
-79.447625^{\circ}\end{array}$ & $\begin{array}{l}\text { In front of } \\
\text { housing }\end{array}$ & $\begin{array}{l}\text { New tree. Improved semi- } \\
\text { detached home. }\end{array}$ \\
\hline $\begin{array}{l}\text { Eastern } \\
\text { White Cedar }\end{array}$ & $\begin{array}{l}\text { Thuja } \\
\text { occidentalis }\end{array}$ & defoliation & 1 & $\begin{array}{l}43.659904^{\circ}, \\
-79.450228^{\circ}\end{array}$ & $\begin{array}{l}\text { In front of } \\
\text { housing }\end{array}$ & $\begin{array}{l}\text { New tree. Improved semi- } \\
\text { detached home. }\end{array}$ \\
\hline $\begin{array}{l}\text { Eastern } \\
\text { White Cedar }\end{array}$ & $\begin{array}{l}\text { Thuja } \\
\text { occidentalis }\end{array}$ & defoliation & 1 & $\begin{array}{l}43.659905^{\circ}, \\
-79.450224^{\circ}\end{array}$ & $\begin{array}{l}\text { In front of } \\
\text { housing }\end{array}$ & $\begin{array}{l}\text { New tree. Improved semi- } \\
\text { detached home. }\end{array}$ \\
\hline $\begin{array}{l}\text { Eastern } \\
\text { White Cedar }\end{array}$ & $\begin{array}{l}\text { Thuja } \\
\text { occidentalis }\end{array}$ & good condition & 0 & $\begin{array}{l}43.659906^{\circ}, \\
-79.450221^{\circ}\end{array}$ & $\begin{array}{l}\text { In front of } \\
\text { housing }\end{array}$ & $\begin{array}{l}\text { New tree. Improved semi- } \\
\text { detached home. }\end{array}$ \\
\hline $\begin{array}{l}\text { Eastern } \\
\text { White Cedar }\end{array}$ & $\begin{array}{l}\text { Thuja } \\
\text { occidentalis }\end{array}$ & good condition & 0 & $\begin{array}{l}43.659907^{\circ}, \\
-79.450217^{\circ}\end{array}$ & $\begin{array}{l}\text { In front of } \\
\text { housing }\end{array}$ & $\begin{array}{l}\text { New tree. Improved semi- } \\
\text { detached home. }\end{array}$ \\
\hline $\begin{array}{l}\text { Eastern } \\
\text { White Cedar }\end{array}$ & $\begin{array}{l}\text { Thuja } \\
\text { occidentalis }\end{array}$ & defoliation & 1 & $\begin{array}{l}43.659908^{\circ}, \\
-79.450212^{\circ}\end{array}$ & $\begin{array}{l}\text { In front of } \\
\text { housing }\end{array}$ & $\begin{array}{l}\text { New tree. Improved semi- } \\
\text { detached home. }\end{array}$ \\
\hline $\begin{array}{l}\text { Eastern } \\
\text { White Cedar }\end{array}$ & $\begin{array}{l}\text { Thuja } \\
\text { occidentalis }\end{array}$ & defoliation & 1 & $\begin{array}{l}43.659909^{\circ}, \\
-79.450207^{\circ}\end{array}$ & $\begin{array}{l}\text { In front of } \\
\text { housing }\end{array}$ & $\begin{array}{l}\text { New tree. Improved semi- } \\
\text { detached home. }\end{array}$ \\
\hline $\begin{array}{l}\text { Eastern } \\
\text { White Cedar }\end{array}$ & $\begin{array}{l}\text { Thuja } \\
\text { occidentalis }\end{array}$ & defoliation & 1 & $\begin{array}{l}43.659911^{\circ}, \\
-79.450201^{\circ}\end{array}$ & $\begin{array}{l}\text { In front of } \\
\text { housing }\end{array}$ & $\begin{array}{l}\text { New tree. Improved semi- } \\
\text { detached home. }\end{array}$ \\
\hline $\begin{array}{l}\text { Eastern } \\
\text { White Cedar }\end{array}$ & $\begin{array}{l}\text { Thuja } \\
\text { occidentalis }\end{array}$ & good condition & 0 & $\begin{array}{l}43.659913^{\circ}, \\
-79.450194^{\circ}\end{array}$ & $\begin{array}{l}\text { In front of } \\
\text { housing }\end{array}$ & $\begin{array}{l}\text { New tree. Improved semi- } \\
\text { detached home. }\end{array}$ \\
\hline $\begin{array}{l}\text { Eastern } \\
\text { White Cedar }\end{array}$ & $\begin{array}{l}\text { Thuja } \\
\text { occidentalis }\end{array}$ & good condition & 0 & $\begin{array}{l}43.659914^{\circ}, \\
-79.450184^{\circ}\end{array}$ & $\begin{array}{l}\text { In front of } \\
\text { housing }\end{array}$ & $\begin{array}{l}\text { New tree. Improved semi- } \\
\text { detached home. }\end{array}$ \\
\hline $\begin{array}{l}\text { Eastern } \\
\text { White Cedar }\end{array}$ & $\begin{array}{l}\text { Thuja } \\
\text { occidentalis }\end{array}$ & good condition & 0 & $\begin{array}{l}43.659916^{\circ}, \\
-79.450178^{\circ}\end{array}$ & $\begin{array}{l}\text { In front of } \\
\text { housing }\end{array}$ & $\begin{array}{l}\text { New tree. Improved semi- } \\
\text { detached home. }\end{array}$ \\
\hline $\begin{array}{l}\text { Eastern } \\
\text { White Cedar }\end{array}$ & $\begin{array}{l}\text { Thuja } \\
\text { occidentalis }\end{array}$ & defoliation & 1 & $\begin{array}{l}43.659917^{\circ}, \\
-79.450169^{\circ}\end{array}$ & $\begin{array}{l}\text { In front of } \\
\text { housing }\end{array}$ & $\begin{array}{l}\text { New tree. Improved semi- } \\
\text { detached home. }\end{array}$ \\
\hline $\begin{array}{l}\text { Eastern } \\
\text { White Cedar }\end{array}$ & $\begin{array}{l}\text { Thuja } \\
\text { occidentalis }\end{array}$ & defoliation & 1 & $\begin{array}{l}43.659919^{\circ}, \\
-79.450160^{\circ}\end{array}$ & $\begin{array}{l}\text { In front of } \\
\text { housing }\end{array}$ & $\begin{array}{l}\text { New tree. Improved semi- } \\
\text { detached home. }\end{array}$ \\
\hline $\begin{array}{l}\text { Eastern } \\
\text { White Cedar }\end{array}$ & $\begin{array}{l}\text { Thuja } \\
\text { occidentalis }\end{array}$ & good condition & 0 & $\begin{array}{l}43.660184^{\circ}, \\
-79.449136^{\circ}\end{array}$ & $\begin{array}{l}\text { In front of } \\
\text { housing }\end{array}$ & $\begin{array}{l}\text { New tree. Improved semi- } \\
\text { detached home. }\end{array}$ \\
\hline $\begin{array}{l}\text { Eastern } \\
\text { White Cedar }\end{array}$ & $\begin{array}{l}\text { Thuja } \\
\text { occidentalis }\end{array}$ & good condition & 0 & $\begin{array}{l}43.660187^{\circ}, \\
-79.449133^{\circ}\end{array}$ & $\begin{array}{l}\text { In front of } \\
\text { housing }\end{array}$ & $\begin{array}{l}\text { New tree. Improved semi- } \\
\text { detached home. }\end{array}$ \\
\hline $\begin{array}{l}\text { Eastern } \\
\text { White Cedar }\end{array}$ & $\begin{array}{l}\text { Thuja } \\
\text { occidentalis }\end{array}$ & good condition & 0 & $\begin{array}{l}43.660327^{\circ}, \\
-79.450103^{\circ}\end{array}$ & $\begin{array}{l}\text { In front of } \\
\text { housing }\end{array}$ & $\begin{array}{l}\text { New tree. Improved semi- } \\
\text { detached home. }\end{array}$ \\
\hline $\begin{array}{l}\text { Eastern } \\
\text { White Cedar }\end{array}$ & $\begin{array}{l}\text { Thuja } \\
\text { occidentalis }\end{array}$ & good condition & 0 & $\begin{array}{l}43.660330^{\circ}, \\
-79.449100^{\circ}\end{array}$ & $\begin{array}{l}\text { In front of } \\
\text { housing }\end{array}$ & $\begin{array}{l}\text { New tree. Improved semi- } \\
\text { detached home. }\end{array}$ \\
\hline $\begin{array}{l}\text { Eastern } \\
\text { White Cedar }\end{array}$ & $\begin{array}{l}\text { Thuja } \\
\text { occidentalis }\end{array}$ & good condition & 0 & $\begin{array}{l}43.660334^{\circ}, \\
-79.449106^{\circ}\end{array}$ & $\begin{array}{l}\text { In front of } \\
\text { housing }\end{array}$ & $\begin{array}{l}\text { New tree. Improved semi- } \\
\text { detached home. }\end{array}$ \\
\hline $\begin{array}{l}\text { Eastern } \\
\text { White Cedar }\end{array}$ & $\begin{array}{l}\text { Thuja } \\
\text { occidentalis }\end{array}$ & good condition & 0 & $\begin{array}{l}43.660338^{\circ}, \\
-79.450111^{\circ}\end{array}$ & $\begin{array}{l}\text { In front of } \\
\text { housing }\end{array}$ & $\begin{array}{l}\text { New tree. Improved semi- } \\
\text { detached home. }\end{array}$ \\
\hline $\begin{array}{l}\text { Eastern } \\
\text { White Cedar }\end{array}$ & $\begin{array}{l}\text { Thuja } \\
\text { occidentalis }\end{array}$ & discoloured leaves & 1 & $\begin{array}{l}43.660651^{\circ}, \\
-79.448191^{\circ}\end{array}$ & $\begin{array}{l}\text { In front of } \\
\text { housing }\end{array}$ & $\begin{array}{l}\text { New tree. Improved semi- } \\
\text { detached home. }\end{array}$ \\
\hline $\begin{array}{l}\text { Eastern } \\
\text { White Cedar }\end{array}$ & $\begin{array}{l}\text { Thuja } \\
\text { occidentalis }\end{array}$ & good condition & 0 & $\begin{array}{l}43.660971^{\circ} \\
-79.448049^{\circ}\end{array}$ & $\begin{array}{l}\text { In front of } \\
\text { housing }\end{array}$ & $\begin{array}{l}\text { New tree. Improved semi- } \\
\text { detached home. }\end{array}$ \\
\hline $\begin{array}{l}\text { Eastern } \\
\text { White Cedar }\end{array}$ & $\begin{array}{l}\text { Thuja } \\
\text { occidentalis }\end{array}$ & good condition & 1 & $\begin{array}{l}43.660994^{\circ}, \\
-79.450373^{\circ}\end{array}$ & $\begin{array}{l}\text { In front of } \\
\text { housing }\end{array}$ & $\begin{array}{l}\text { New tree. Improved semi- } \\
\text { detached home. }\end{array}$ \\
\hline $\begin{array}{l}\text { Eastern } \\
\text { White Cedar }\end{array}$ & $\begin{array}{l}\text { Thuja } \\
\text { occidentalis }\end{array}$ & $\begin{array}{l}\text { tree lean, defoliation, } \\
\text { discoloured leaves }\end{array}$ & 3 & $\begin{array}{l}43.661250^{\circ}, \\
-79.449144^{\circ}\end{array}$ & $\begin{array}{l}\text { In front of } \\
\text { housing }\end{array}$ & $\begin{array}{l}\text { New tree. Improved semi- } \\
\text { detached home. }\end{array}$ \\
\hline $\begin{array}{l}\text { Eastern } \\
\text { White Cedar }\end{array}$ & $\begin{array}{l}\text { Thuja } \\
\text { occidentalis }\end{array}$ & good condition & 0 & $\begin{array}{l}43.661252^{\circ}, \\
-79.449142^{\circ}\end{array}$ & $\begin{array}{l}\text { In front of } \\
\text { housing }\end{array}$ & $\begin{array}{l}\text { New tree. Improved semi- } \\
\text { detached home. }\end{array}$ \\
\hline $\begin{array}{l}\text { Eastern } \\
\text { White Cedar }\end{array}$ & $\begin{array}{l}\text { Thuja } \\
\text { occidentalis }\end{array}$ & $\begin{array}{l}\text { tree lean, defoliation, } \\
\text { discoloured leaves }\end{array}$ & 3 & $\begin{array}{l}43.661255^{\circ}, \\
-79.449124^{\circ}\end{array}$ & $\begin{array}{l}\text { In front of } \\
\text { housing }\end{array}$ & $\begin{array}{l}\text { New tree. Improved semi- } \\
\text { detached home. }\end{array}$ \\
\hline $\begin{array}{l}\text { Eastern } \\
\text { White Cedar }\end{array}$ & $\begin{array}{l}\text { Thuja } \\
\text { occidentalis }\end{array}$ & $\begin{array}{l}\text { tree lean, defoliation, } \\
\text { discoloured leaves }\end{array}$ & 3 & $\begin{array}{l}43.661257^{\circ} \\
-79.449115^{\circ}\end{array}$ & $\begin{array}{l}\text { In front of } \\
\text { housing }\end{array}$ & $\begin{array}{l}\text { New tree. Improved semi- } \\
\text { detached home. }\end{array}$ \\
\hline
\end{tabular}




\begin{tabular}{|c|c|c|c|c|c|c|}
\hline $\begin{array}{l}\text { Eastern } \\
\text { White Cedar }\end{array}$ & $\begin{array}{l}\text { Thuja } \\
\text { occidentalis }\end{array}$ & $\begin{array}{l}\text { tree lean, defoliation, } \\
\text { discoloured leaves }\end{array}$ & 3 & $\begin{array}{l}43.661259^{\circ} \\
-79.449102^{\circ}\end{array}$ & $\begin{array}{l}\text { In front of } \\
\text { housing }\end{array}$ & $\begin{array}{l}\text { New tree. Improved semi- } \\
\text { detached home. }\end{array}$ \\
\hline $\begin{array}{l}\text { Eastern } \\
\text { White Cedar }\end{array}$ & $\begin{array}{l}\text { Thuja } \\
\text { occidentalis }\end{array}$ & good condition & 0 & $\begin{array}{l}43.658090^{\circ}, \\
-79.447023^{\circ}\end{array}$ & $\begin{array}{l}\text { In front of } \\
\text { housing }\end{array}$ & New tree. Row home. \\
\hline $\begin{array}{l}\text { Eastern } \\
\text { White Cedar }\end{array}$ & $\begin{array}{l}\text { Thuja } \\
\text { occidentalis }\end{array}$ & good condition & 0 & $\begin{array}{l}43.658200^{\circ}, \\
-79.446896^{\circ}\end{array}$ & $\begin{array}{l}\text { In front of } \\
\text { housing }\end{array}$ & New tree. Row home. \\
\hline $\begin{array}{l}\text { Eastern } \\
\text { White Cedar }\end{array}$ & $\begin{array}{l}\text { Thuja } \\
\text { occidentalis }\end{array}$ & defoliation, dead bracnhes & 2 & $\begin{array}{l}43.659249^{\circ} \\
-79.446665^{\circ}\end{array}$ & $\begin{array}{l}\text { In front of } \\
\text { housing }\end{array}$ & $\begin{array}{l}\text { New tree. Semi-detached } \\
\text { home. Renovation status } \\
\text { unclear. }\end{array}$ \\
\hline $\begin{array}{l}\text { Eastern } \\
\text { White Cedar }\end{array}$ & $\begin{array}{l}\text { Thuja } \\
\text { occidentalis }\end{array}$ & good condition. & 0 & $\begin{array}{l}43.659681^{\circ} \\
-79.446840^{\circ}\end{array}$ & $\begin{array}{l}\text { In front of } \\
\text { housing }\end{array}$ & $\begin{array}{l}\text { New tree. Semi-detached } \\
\text { home. Renovation status } \\
\text { unclear. }\end{array}$ \\
\hline $\begin{array}{l}\text { Eastern } \\
\text { White Cedar }\end{array}$ & $\begin{array}{l}\text { Thuja } \\
\text { occidentalis }\end{array}$ & good condition & 0 & $\begin{array}{l}43.660002^{\circ} \\
-79.447052^{\circ}\end{array}$ & $\begin{array}{l}\text { In front of } \\
\text { housing }\end{array}$ & $\begin{array}{l}\text { New tree. Semi-detached } \\
\text { home. Renovation status } \\
\text { unclear. }\end{array}$ \\
\hline $\begin{array}{l}\text { Eastern } \\
\text { White Cedar }\end{array}$ & $\begin{array}{l}\text { Thuja } \\
\text { occidentalis }\end{array}$ & good condition & 0 & $\begin{array}{l}43.660011^{\circ} \\
-79.447031^{\circ}\end{array}$ & $\begin{array}{l}\text { In front of } \\
\text { housing }\end{array}$ & $\begin{array}{l}\text { New tree. Semi-detached } \\
\text { home. Renovation status } \\
\text { unclear. }\end{array}$ \\
\hline $\begin{array}{l}\text { Eastern } \\
\text { White Cedar }\end{array}$ & $\begin{array}{l}\text { Thuja } \\
\text { occidentalis }\end{array}$ & good condition & 0 & $\begin{array}{l}43.660032^{\circ} \\
-79.446948^{\circ}\end{array}$ & $\begin{array}{l}\text { In front of } \\
\text { housing }\end{array}$ & $\begin{array}{l}\text { New tree. Semi-detached } \\
\text { home. Renovation status } \\
\text { unclear. }\end{array}$ \\
\hline $\begin{array}{l}\text { Eastern } \\
\text { White Cedar }\end{array}$ & $\begin{array}{l}\text { Thuja } \\
\text { occidentalis }\end{array}$ & good condition & 0 & $\begin{array}{l}43.660085^{\circ} \\
-79.446702^{\circ}\end{array}$ & $\begin{array}{l}\text { In front of } \\
\text { housing }\end{array}$ & $\begin{array}{l}\text { New tree. Semi-detached } \\
\text { home. Renovation status } \\
\text { unclear. }\end{array}$ \\
\hline $\begin{array}{l}\text { Eastern } \\
\text { White Cedar }\end{array}$ & $\begin{array}{l}\text { Thuja } \\
\text { occidentalis }\end{array}$ & good condition & 0 & $\begin{array}{l}43.660091^{\circ}, \\
-79.446733^{\circ}\end{array}$ & $\begin{array}{l}\text { In front of } \\
\text { housing }\end{array}$ & $\begin{array}{l}\text { New tree. Semi-detached } \\
\text { home. Renovation status } \\
\text { unclear. }\end{array}$ \\
\hline $\begin{array}{l}\text { Eastern } \\
\text { White Cedar }\end{array}$ & $\begin{array}{l}\text { Thuja } \\
\text { occidentalis }\end{array}$ & good condition & 0 & $\begin{array}{l}43.660102^{\circ}, \\
-79.446734^{\circ}\end{array}$ & $\begin{array}{l}\text { In front of } \\
\text { housing }\end{array}$ & $\begin{array}{l}\text { New tree. Semi-detached } \\
\text { home. Renovation status } \\
\text { unclear. }\end{array}$ \\
\hline $\begin{array}{l}\text { Eastern } \\
\text { White Cedar }\end{array}$ & $\begin{array}{l}\text { Thuja } \\
\text { occidentalis }\end{array}$ & good condition & 0 & $\begin{array}{l}43.660450^{\circ} \\
-79.447047^{\circ}\end{array}$ & $\begin{array}{l}\text { In front of } \\
\text { housing }\end{array}$ & $\begin{array}{l}\text { New tree. Semi-detached } \\
\text { home. Renovation status } \\
\text { unclear. }\end{array}$ \\
\hline $\begin{array}{l}\text { Eastern } \\
\text { White Cedar }\end{array}$ & $\begin{array}{l}\text { Thuja } \\
\text { occidentalis }\end{array}$ & good condition & 0 & $\begin{array}{l}43.660450^{\circ}, \\
-79.447060^{\circ}\end{array}$ & $\begin{array}{l}\text { In front of } \\
\text { housing }\end{array}$ & $\begin{array}{l}\text { New tree. Semi-detached } \\
\text { home. Renovation status } \\
\text { unclear. }\end{array}$ \\
\hline $\begin{array}{l}\text { Eastern } \\
\text { White Cedar }\end{array}$ & $\begin{array}{l}\text { Thuja } \\
\text { occidentalis }\end{array}$ & good condition & 0 & $\begin{array}{l}43.660535^{\circ} \\
-79.446909^{\circ}\end{array}$ & $\begin{array}{l}\text { In front of } \\
\text { housing }\end{array}$ & $\begin{array}{l}\text { New tree. Semi-detached } \\
\text { home. Renovation status } \\
\text { unclear. }\end{array}$ \\
\hline $\begin{array}{l}\text { Eastern } \\
\text { White Cedar }\end{array}$ & $\begin{array}{l}\text { Thuja } \\
\text { occidentalis }\end{array}$ & good condition & 0 & $\begin{array}{l}43.660542^{\circ} \\
-79.446910^{\circ}\end{array}$ & $\begin{array}{l}\text { In front of } \\
\text { housing }\end{array}$ & $\begin{array}{l}\text { New tree. Semi-detached } \\
\text { home. Renovation status } \\
\text { unclear. }\end{array}$ \\
\hline $\begin{array}{l}\text { Eastern } \\
\text { White Cedar }\end{array}$ & $\begin{array}{l}\text { Thuja } \\
\text { occidentalis }\end{array}$ & good condition & 0 & $\begin{array}{l}43.660550^{\circ}, \\
-79.446918^{\circ}\end{array}$ & $\begin{array}{l}\text { In front of } \\
\text { housing }\end{array}$ & $\begin{array}{l}\text { New tree. Semi-detached } \\
\text { home. Renovation status } \\
\text { unclear. }\end{array}$ \\
\hline $\begin{array}{l}\text { Eastern } \\
\text { White Cedar }\end{array}$ & $\begin{array}{l}\text { Thuja } \\
\text { occidentalis }\end{array}$ & good condition & 0 & $\begin{array}{l}43.660933^{\circ} \\
-79.447072^{\circ}\end{array}$ & $\begin{array}{l}\text { In front of } \\
\text { housing }\end{array}$ & $\begin{array}{l}\text { New tree. Semi-detached } \\
\text { home. Renovation status } \\
\text { unclear. }\end{array}$ \\
\hline $\begin{array}{l}\text { Eastern } \\
\text { White Cedar }\end{array}$ & $\begin{array}{l}\text { Thuja } \\
\text { occidentalis }\end{array}$ & good condition & 0 & $\begin{array}{l}43.661655^{\circ} \\
-79.447186^{\circ}\end{array}$ & $\begin{array}{l}\text { In front of } \\
\text { housing }\end{array}$ & $\begin{array}{l}\text { New tree. Semi-detached } \\
\text { home. Renovation status } \\
\text { unclear. }\end{array}$ \\
\hline $\begin{array}{l}\text { Eastern } \\
\text { White Cedar }\end{array}$ & $\begin{array}{l}\text { Thuja } \\
\text { occidentalis }\end{array}$ & discoloured leaves & 1 & $\begin{array}{l}43.659041^{\circ}, \\
-79.449870^{\circ}\end{array}$ & $\begin{array}{l}\text { In front of } \\
\text { housing }\end{array}$ & $\begin{array}{l}\text { Unimproved semi-detached } \\
\text { home. }\end{array}$ \\
\hline $\begin{array}{l}\text { Eastern } \\
\text { White Cedar }\end{array}$ & $\begin{array}{l}\text { Thuja } \\
\text { occidentalis }\end{array}$ & discoloured leaves & 1 & $\begin{array}{l}43.659047^{\circ}, \\
-79.449871^{\circ}\end{array}$ & $\begin{array}{l}\text { In front of } \\
\text { housing }\end{array}$ & $\begin{array}{l}\text { Unimproved semi-detached } \\
\text { home. }\end{array}$ \\
\hline $\begin{array}{l}\text { Eastern } \\
\text { White Cedar }\end{array}$ & $\begin{array}{l}\text { Thuja } \\
\text { occidentalis }\end{array}$ & tree lean, peeling bark & 2 & $\begin{array}{l}43.659904^{\circ}, \\
-79.447471^{\circ}\end{array}$ & $\begin{array}{l}\text { In front of } \\
\text { housing }\end{array}$ & $\begin{array}{l}\text { Unimproved semi-detached } \\
\text { home. }\end{array}$ \\
\hline $\begin{array}{l}\text { Eastern } \\
\text { White Cedar }\end{array}$ & $\begin{array}{l}\text { Thuja } \\
\text { occidentalis }\end{array}$ & tree lean, defoliation & 2 & $\begin{array}{l}43.659960^{\circ}, \\
-79.447346^{\circ} \\
\end{array}$ & $\begin{array}{l}\text { In front of } \\
\text { housing }\end{array}$ & $\begin{array}{l}\text { Unimproved semi-detached } \\
\text { home. }\end{array}$ \\
\hline $\begin{array}{l}\text { Eastern } \\
\text { White Cedar }\end{array}$ & $\begin{array}{l}\text { Thuja } \\
\text { occidentalis }\end{array}$ & good condition & 0 & $\begin{array}{l}43.660732^{\circ}, \\
-79.447971^{\circ}\end{array}$ & $\begin{array}{l}\text { In front of } \\
\text { housing }\end{array}$ & $\begin{array}{l}\text { Unimproved semi-detached } \\
\text { home. }\end{array}$ \\
\hline $\begin{array}{l}\text { Eastern } \\
\text { White Cedar }\end{array}$ & $\begin{array}{l}\text { Thuja } \\
\text { occidentalis }\end{array}$ & good condition & 0 & $\begin{array}{l}43.658624^{\circ}, \\
-79.448422^{\circ}\end{array}$ & $\begin{array}{l}\text { In front of } \\
\text { housing }\end{array}$ & $\begin{array}{l}\text { Improved semi-detached } \\
\text { home. }\end{array}$ \\
\hline $\begin{array}{l}\text { Eastern } \\
\text { White Cedar }\end{array}$ & $\begin{array}{l}\text { Thuja } \\
\text { occidentalis }\end{array}$ & good condition & 0 & $\begin{array}{l}43.659749^{\circ} \\
-79.449145^{\circ}\end{array}$ & $\begin{array}{l}\text { In front of } \\
\text { housing }\end{array}$ & $\begin{array}{l}\text { Improved semi-detached } \\
\text { home. }\end{array}$ \\
\hline $\begin{array}{l}\text { Eastern } \\
\text { White Cedar }\end{array}$ & $\begin{array}{l}\text { Thuja } \\
\text { occidentalis }\end{array}$ & good condition & 0 & $\begin{array}{l}43.659750^{\circ}, \\
-79.449141^{\circ}\end{array}$ & $\begin{array}{l}\text { In front of } \\
\text { housing }\end{array}$ & $\begin{array}{l}\text { Improved semi-detached } \\
\text { home. }\end{array}$ \\
\hline
\end{tabular}




\begin{tabular}{|c|c|c|c|c|c|c|}
\hline $\begin{array}{l}\text { Eastern } \\
\text { White Cedar }\end{array}$ & $\begin{array}{l}\text { Thuja } \\
\text { occidentalis }\end{array}$ & good condition & 0 & $\begin{array}{l}43.659751^{\circ}, \\
-79.449137^{\circ} \\
\end{array}$ & $\begin{array}{l}\text { In front of } \\
\text { housing }\end{array}$ & $\begin{array}{l}\text { Improved semi-detached } \\
\text { home. }\end{array}$ \\
\hline $\begin{array}{l}\text { Eastern } \\
\text { White Cedar }\end{array}$ & $\begin{array}{l}\text { Thuja } \\
\text { occidentalis }\end{array}$ & good condition & 0 & $\begin{array}{l}43.659752^{\circ}, \\
-79.449128^{\circ}\end{array}$ & $\begin{array}{l}\text { In front of } \\
\text { housing }\end{array}$ & $\begin{array}{l}\text { Improved semi-detached } \\
\text { home. }\end{array}$ \\
\hline $\begin{array}{l}\text { Eastern } \\
\text { White Cedar }\end{array}$ & $\begin{array}{l}\text { Thuja } \\
\text { occidentalis }\end{array}$ & good condition & 0 & $\begin{array}{l}43.659752^{\circ}, \\
-79.449134^{\circ}\end{array}$ & $\begin{array}{l}\text { In front of } \\
\text { housing }\end{array}$ & $\begin{array}{l}\text { Improved semi-detached } \\
\text { home. }\end{array}$ \\
\hline $\begin{array}{l}\text { Eastern } \\
\text { White Cedar }\end{array}$ & $\begin{array}{l}\text { Thuja } \\
\text { occidentalis }\end{array}$ & good condition & 0 & $\begin{array}{l}43.659753^{\circ} \\
-79.449164^{\circ}\end{array}$ & $\begin{array}{l}\text { In front of } \\
\text { housing }\end{array}$ & $\begin{array}{l}\text { Improved semi-detached } \\
\text { home. }\end{array}$ \\
\hline $\begin{array}{l}\text { Eastern } \\
\text { White Cedar }\end{array}$ & $\begin{array}{l}\text { Thuja } \\
\text { occidentalis }\end{array}$ & good condition & 0 & $\begin{array}{l}43.659753^{\circ} \\
-79.449167^{\circ}\end{array}$ & $\begin{array}{l}\text { In front of } \\
\text { housing }\end{array}$ & $\begin{array}{l}\text { Improved semi-detached } \\
\text { home. }\end{array}$ \\
\hline $\begin{array}{l}\text { Eastern } \\
\text { White Cedar }\end{array}$ & $\begin{array}{l}\text { Thuja } \\
\text { occidentalis }\end{array}$ & good condition & 0 & $\begin{array}{l}43.659755^{\circ} \\
-79.449171^{\circ}\end{array}$ & $\begin{array}{l}\text { In front of } \\
\text { housing }\end{array}$ & $\begin{array}{l}\text { Improved semi-detached } \\
\text { home. }\end{array}$ \\
\hline $\begin{array}{l}\text { Eastern } \\
\text { White Cedar }\end{array}$ & $\begin{array}{l}\text { Thuja } \\
\text { occidentalis }\end{array}$ & good condition & 0 & $\begin{array}{l}43.659757^{\circ}, \\
-79.449171^{\circ} \\
\end{array}$ & $\begin{array}{l}\text { In front of } \\
\text { housing }\end{array}$ & $\begin{array}{l}\text { Improved semi-detached } \\
\text { home. }\end{array}$ \\
\hline $\begin{array}{l}\text { Eastern } \\
\text { White Cedar }\end{array}$ & $\begin{array}{l}\text { Thuja } \\
\text { occidentalis }\end{array}$ & good condition & 0 & $\begin{array}{l}43.659759^{\circ} \\
-79.449171^{\circ}\end{array}$ & $\begin{array}{l}\text { In front of } \\
\text { housing }\end{array}$ & $\begin{array}{l}\text { Improved semi-detached } \\
\text { home. }\end{array}$ \\
\hline $\begin{array}{l}\text { Eastern } \\
\text { White Cedar }\end{array}$ & $\begin{array}{l}\text { Thuja } \\
\text { occidentalis }\end{array}$ & good condition & 0 & $\begin{array}{l}43.659760^{\circ} \\
-79.449172^{\circ}\end{array}$ & $\begin{array}{l}\text { In front of } \\
\text { housing }\end{array}$ & $\begin{array}{l}\text { Improved semi-detached } \\
\text { home. }\end{array}$ \\
\hline $\begin{array}{l}\text { Eastern } \\
\text { White Cedar }\end{array}$ & $\begin{array}{l}\text { Thuja } \\
\text { occidentalis }\end{array}$ & good condition & 0 & $\begin{array}{l}43.659761^{\circ} \\
-79.449170^{\circ}\end{array}$ & $\begin{array}{l}\text { In front of } \\
\text { housing }\end{array}$ & $\begin{array}{l}\text { Improved semi-detached } \\
\text { home. }\end{array}$ \\
\hline $\begin{array}{l}\text { Eastern } \\
\text { White Cedar }\end{array}$ & $\begin{array}{l}\text { Thuja } \\
\text { occidentalis }\end{array}$ & good condition & 0 & $\begin{array}{l}43.659761^{\circ} \\
-79.449173^{\circ}\end{array}$ & $\begin{array}{l}\text { In front of } \\
\text { housing }\end{array}$ & $\begin{array}{l}\text { Improved semi-detached } \\
\text { home. }\end{array}$ \\
\hline $\begin{array}{l}\text { Eastern } \\
\text { White Cedar }\end{array}$ & $\begin{array}{l}\text { Thuja } \\
\text { occidentalis }\end{array}$ & good condition & 0 & $\begin{array}{l}43.659762^{\circ} \\
-79.449172^{\circ}\end{array}$ & $\begin{array}{l}\text { In front of } \\
\text { housing }\end{array}$ & $\begin{array}{l}\text { Improved semi-detached } \\
\text { home. }\end{array}$ \\
\hline $\begin{array}{l}\text { Eastern } \\
\text { White Cedar }\end{array}$ & $\begin{array}{l}\text { Thuja } \\
\text { occidentalis }\end{array}$ & good condition & 0 & $\begin{array}{l}43.659768^{\circ} \\
-79.449097^{\circ}\end{array}$ & $\begin{array}{l}\text { In front of } \\
\text { housing }\end{array}$ & $\begin{array}{l}\text { Improved semi-detached } \\
\text { home. }\end{array}$ \\
\hline $\begin{array}{l}\text { Eastern } \\
\text { White Cedar }\end{array}$ & $\begin{array}{l}\text { Thuja } \\
\text { occidentalis }\end{array}$ & good condition & 0 & $\begin{array}{l}43.659771^{\circ}, \\
-79.449075^{\circ}\end{array}$ & $\begin{array}{l}\text { In front of } \\
\text { housing }\end{array}$ & $\begin{array}{l}\text { Improved semi-detached } \\
\text { home. }\end{array}$ \\
\hline $\begin{array}{l}\text { Eastern } \\
\text { White Cedar }\end{array}$ & $\begin{array}{l}\text { Thuja } \\
\text { occidentalis }\end{array}$ & good condition & 0 & $\begin{array}{l}43.659784^{\circ}, \\
-79.449190^{\circ}\end{array}$ & $\begin{array}{l}\text { In front of } \\
\text { housing }\end{array}$ & $\begin{array}{l}\text { Improved semi-detached } \\
\text { home. }\end{array}$ \\
\hline $\begin{array}{l}\text { Eastern } \\
\text { White Cedar }\end{array}$ & $\begin{array}{l}\text { Thuja } \\
\text { occidentalis }\end{array}$ & good condition & 0 & $\begin{array}{l}43.659790^{\circ}, \\
-79.449193^{\circ} \\
\end{array}$ & $\begin{array}{l}\text { In front of } \\
\text { housing }\end{array}$ & $\begin{array}{l}\text { Improved semi-detached } \\
\text { home. }\end{array}$ \\
\hline $\begin{array}{l}\text { Eastern } \\
\text { White Cedar }\end{array}$ & $\begin{array}{l}\text { Thuja } \\
\text { occidentalis }\end{array}$ & tree lean & 1 & $\begin{array}{l}43.660094^{\circ}, \\
-79.447969^{\circ}\end{array}$ & $\begin{array}{l}\text { In front of } \\
\text { housing }\end{array}$ & $\begin{array}{l}\text { Improved semi-detached } \\
\text { home. }\end{array}$ \\
\hline $\begin{array}{l}\text { Eastern } \\
\text { White Cedar }\end{array}$ & $\begin{array}{l}\text { Thuja } \\
\text { occidentalis }\end{array}$ & good condition & 0 & $\begin{array}{l}43.660228^{\circ} \\
-79.447775^{\circ}\end{array}$ & $\begin{array}{l}\text { In front of } \\
\text { housing }\end{array}$ & $\begin{array}{l}\text { Improved semi-detached } \\
\text { home. }\end{array}$ \\
\hline $\begin{array}{l}\text { Eastern } \\
\text { White Cedar }\end{array}$ & $\begin{array}{l}\text { Thuja } \\
\text { occidentalis }\end{array}$ & tree lean & 1 & $\begin{array}{l}43.660653^{\circ}, \\
-79.447950^{\circ}\end{array}$ & $\begin{array}{l}\text { In front of } \\
\text { housing }\end{array}$ & $\begin{array}{l}\text { Improved semi-detached } \\
\text { home. }\end{array}$ \\
\hline $\begin{array}{l}\text { Eastern } \\
\text { White Cedar }\end{array}$ & $\begin{array}{l}\text { Thuja } \\
\text { occidentalis }\end{array}$ & tree lean & 1 & $\begin{array}{l}43.660779^{\circ} \\
-79.448205^{\circ}\end{array}$ & $\begin{array}{l}\text { In front of } \\
\text { housing }\end{array}$ & $\begin{array}{l}\text { Improved semi-detached } \\
\text { home. }\end{array}$ \\
\hline $\begin{array}{l}\text { Eastern } \\
\text { White Cedar }\end{array}$ & $\begin{array}{l}\text { Thuja } \\
\text { occidentalis }\end{array}$ & good condition & 0 & $\begin{array}{l}43.661549^{\circ} \\
-79.447703^{\circ}\end{array}$ & $\begin{array}{l}\text { In front of } \\
\text { housing }\end{array}$ & $\begin{array}{l}\text { Improved semi-detached } \\
\text { home. }\end{array}$ \\
\hline $\begin{array}{l}\text { Eastern } \\
\text { White Cedar }\end{array}$ & $\begin{array}{l}\text { Thuja } \\
\text { occidentalis }\end{array}$ & good condition & 0 & $\begin{array}{l}43.661551^{\circ}, \\
-79.447652^{\circ}\end{array}$ & $\begin{array}{l}\text { In front of } \\
\text { housing }\end{array}$ & $\begin{array}{l}\text { Improved semi-detached } \\
\text { home. }\end{array}$ \\
\hline $\begin{array}{l}\text { Eastern } \\
\text { White Cedar }\end{array}$ & $\begin{array}{l}\text { Juniperus } \\
\text { virginiana }\end{array}$ & good condition & 0 & $\begin{array}{l}43.661555^{\circ} \\
-79.447611^{\circ}\end{array}$ & $\begin{array}{l}\text { In front of } \\
\text { housing }\end{array}$ & $\begin{array}{l}\text { Improved semi-detached } \\
\text { home. }\end{array}$ \\
\hline $\begin{array}{l}\text { Eastern } \\
\text { White Cedar }\end{array}$ & $\begin{array}{l}\text { Juniperus } \\
\text { virginiana } \\
\end{array}$ & good condition & 0 & $\begin{array}{l}43.661559^{\circ} \\
-79.447615^{\circ}\end{array}$ & $\begin{array}{l}\text { In front of } \\
\text { housing }\end{array}$ & $\begin{array}{l}\text { Improved semi-detached } \\
\text { home. }\end{array}$ \\
\hline $\begin{array}{l}\text { Eastern } \\
\text { White Cedar }\end{array}$ & $\begin{array}{l}\text { Juniperus } \\
\text { virginiana }\end{array}$ & good condition & 0 & $\begin{array}{l}43.661567^{\circ} \\
-79.447591^{\circ}\end{array}$ & $\begin{array}{l}\text { In front of } \\
\text { housing }\end{array}$ & $\begin{array}{l}\text { Improved semi-detached } \\
\text { home. }\end{array}$ \\
\hline $\begin{array}{l}\text { Eastern } \\
\text { White Cedar }\end{array}$ & $\begin{array}{l}\text { Thuja } \\
\text { occidentalis }\end{array}$ & tree lean, $10 \%$ dieback & 2 & $\begin{array}{l}43.657965^{\circ} \\
-79.446888^{\circ}\end{array}$ & $\begin{array}{l}\text { In front of } \\
\text { housing }\end{array}$ & Row home. \\
\hline $\begin{array}{l}\text { Eastern } \\
\text { White Cedar }\end{array}$ & $\begin{array}{l}\text { Thuja } \\
\text { occidentalis }\end{array}$ & good condition & 0 & $\begin{array}{l}43.658021^{\circ} \\
-79.446730^{\circ}\end{array}$ & $\begin{array}{l}\text { In front of } \\
\text { housing }\end{array}$ & Row home. \\
\hline $\begin{array}{l}\text { Eastern } \\
\text { White Cedar }\end{array}$ & $\begin{array}{l}\text { Thuja } \\
\text { occidentalis }\end{array}$ & good condition & 0 & $\begin{array}{l}43.660366^{\circ} \\
-79.447037^{\circ}\end{array}$ & $\begin{array}{l}\text { In front of } \\
\text { housing }\end{array}$ & $\begin{array}{l}\text { Semi-detached home. } \\
\text { Renovation status unclear }\end{array}$ \\
\hline $\begin{array}{l}\text { Eastern } \\
\text { White Cedar }\end{array}$ & $\begin{array}{l}\text { Thuja } \\
\text { occidentalis }\end{array}$ & good condition & 0 & $\begin{array}{l}43.660378^{\circ} \\
-79.447037^{\circ}\end{array}$ & $\begin{array}{l}\text { In front of } \\
\text { housing }\end{array}$ & $\begin{array}{l}\text { Semi-detached home. } \\
\text { Renovation status unclear }\end{array}$ \\
\hline $\begin{array}{l}\text { Eastern } \\
\text { White Cedar }\end{array}$ & $\begin{array}{l}\text { Thuja } \\
\text { occidentalis }\end{array}$ & good condition & 0 & $\begin{array}{l}43.660386^{\circ} \\
-79.447038^{\circ} \\
\end{array}$ & $\begin{array}{l}\text { In front of } \\
\text { housing }\end{array}$ & $\begin{array}{l}\text { Semi-detached home. } \\
\text { Renovation status unclear }\end{array}$ \\
\hline $\begin{array}{l}\text { Eastern } \\
\text { White Cedar }\end{array}$ & $\begin{array}{l}\text { Thuja } \\
\text { occidentalis }\end{array}$ & good condition & 0 & $\begin{array}{l}43.661150^{\circ}, \\
-79.447337^{\circ}\end{array}$ & $\begin{array}{l}\text { In front of } \\
\text { housing }\end{array}$ & $\begin{array}{l}\text { Semi-detached home. } \\
\text { Renovation status unclear }\end{array}$ \\
\hline $\begin{array}{l}\text { Eastern } \\
\text { White Cedar }\end{array}$ & $\begin{array}{l}\text { Thuja } \\
\text { occidentalis }\end{array}$ & cracks, defoliation & 2 & $\begin{array}{l}43.658336^{\circ}, \\
-79.446887^{\circ}\end{array}$ & $\begin{array}{l}\text { In front of } \\
\text { housing }\end{array}$ & Stacked townhome. \\
\hline $\begin{array}{l}\text { Eastern } \\
\text { White Pine }\end{array}$ & Pinus strobus & good condition & 0 & $\begin{array}{l}43.660219^{\circ}, \\
-79.450340^{\circ}\end{array}$ & $\begin{array}{l}\text { In front of } \\
\text { housing }\end{array}$ & $\begin{array}{l}\text { New tree. Improved semi- } \\
\text { detached home. }\end{array}$ \\
\hline $\begin{array}{l}\text { Eastern } \\
\text { White Pine }\end{array}$ & Pinus strobus & good condition & 0 & $\begin{array}{l}43.660237^{\circ} \\
-79.450345^{\circ}\end{array}$ & $\begin{array}{l}\text { In front of } \\
\text { housing }\end{array}$ & $\begin{array}{l}\text { New tree. Improved semi- } \\
\text { detached home. }\end{array}$ \\
\hline
\end{tabular}




\begin{tabular}{|c|c|c|c|c|c|c|}
\hline English Oak & Quercus robur & peeling bark & 1 & $\begin{array}{l}43.657603^{\circ}, \\
-79.450192^{\circ}\end{array}$ & $\begin{array}{l}\text { In front of } \\
\text { housing }\end{array}$ & New tree. Row home. \\
\hline English Oak & Quercus robur & small cracks on trunk & 1 & $\begin{array}{l}43.657613^{\circ} \\
-79.450211^{\circ}\end{array}$ & $\begin{array}{l}\text { In front of } \\
\text { housing }\end{array}$ & New tree. Row home. \\
\hline English Oak & Quercus robur & small cracks on trunk & 1 & $\begin{array}{l}43.657642^{\circ}, \\
-79.450248^{\circ}\end{array}$ & $\begin{array}{l}\text { In front of } \\
\text { housing }\end{array}$ & New tree. Row home. \\
\hline English Oak & Quercus robur & good condition & 0 & $\begin{array}{l}43.657662^{\circ}, \\
-79.450264^{\circ}\end{array}$ & $\begin{array}{l}\text { In front of } \\
\text { housing }\end{array}$ & New tree. Row home. \\
\hline English Oak & Quercus robur & defoliation & 1 & $\begin{array}{l}43.657682^{\circ}, \\
-79.450276^{\circ}\end{array}$ & $\begin{array}{l}\text { In front of } \\
\text { housing }\end{array}$ & New tree. Row home. \\
\hline English Oak & Quercus robur & good condition & 0 & $\begin{array}{l}43.658073^{\circ} \\
-79.447442^{\circ}\end{array}$ & $\begin{array}{l}\text { In front of } \\
\text { housing }\end{array}$ & New tree. Row home. \\
\hline English Oak & Quercus robur & dead/broken branches & 1 & $\begin{array}{l}43.658089^{\circ}, \\
-79.447391^{\circ}\end{array}$ & $\begin{array}{l}\text { In front of } \\
\text { housing }\end{array}$ & New tree. Row home. \\
\hline English Oak & Quercus robur & good condition & 1 & $\begin{array}{l}43.658195^{\circ}, \\
-79.446957^{\circ}\end{array}$ & $\begin{array}{l}\text { In front of } \\
\text { housing }\end{array}$ & New tree. Row home. \\
\hline English Oak & Quercus robur & good condition & 0 & $\begin{array}{l}43.657700^{\circ}, \\
-79.450300^{\circ}\end{array}$ & $\begin{array}{l}\text { In front of } \\
\text { housing }\end{array}$ & $\begin{array}{l}\text { New tree. Stacked } \\
\text { townhome. }\end{array}$ \\
\hline English Oak & Quercus robur & good condition & 0 & $\begin{array}{l}43.657720^{\circ}, \\
-79.450315^{\circ}\end{array}$ & $\begin{array}{l}\text { In front of } \\
\text { housing }\end{array}$ & $\begin{array}{l}\text { New tree. Stacked } \\
\text { townhome. }\end{array}$ \\
\hline English Oak & Quercus robur & good condition & 0 & $\begin{array}{l}43.657735^{\circ}, \\
-79.450333^{\circ}\end{array}$ & $\begin{array}{l}\text { In front of } \\
\text { housing }\end{array}$ & $\begin{array}{l}\text { New tree. Stacked } \\
\text { townhome. }\end{array}$ \\
\hline English Oak & Quercus robur & $\begin{array}{l}\text { good condition. Has been } \\
\text { pruned, new shoots } \\
\text { forming. }\end{array}$ & 0 & $\begin{array}{l}43.659865^{\circ} \\
-79.446828^{\circ}\end{array}$ & $\begin{array}{l}\text { In front of } \\
\text { housing }\end{array}$ & $\begin{array}{l}\text { Improved semi-detached } \\
\text { home. }\end{array}$ \\
\hline English Oak & Quercus robur & defoliation & 1 & $\begin{array}{l}43.658638^{\circ} \\
-79.446308^{\circ}\end{array}$ & $\begin{array}{l}\text { In front of } \\
\text { housing }\end{array}$ & $\begin{array}{l}\text { Semi-detached home. } \\
\text { Renovation status unclear. }\end{array}$ \\
\hline English Oak & Quercus robur & defoliation & 1 & $\begin{array}{l}43.658772^{\circ}, \\
-79.446369^{\circ}\end{array}$ & $\begin{array}{l}\text { In front of } \\
\text { housing }\end{array}$ & $\begin{array}{l}\text { Semi-detached home. } \\
\text { Renovation status unclear. }\end{array}$ \\
\hline English Oak & Quercus robur & $\begin{array}{l}10 \% \text { dieback, cracks and } \\
\text { defoliation }\end{array}$ & 2 & $\begin{array}{l}43.659023^{\circ}, \\
-79.446474^{\circ}\end{array}$ & $\begin{array}{l}\text { In front of } \\
\text { housing }\end{array}$ & $\begin{array}{l}\text { Semi-detached home. } \\
\text { Renovation status unclear. }\end{array}$ \\
\hline English Oak & Quercus robur & $\begin{array}{l}\text { defoliation, small cracks on } \\
\text { trunk }\end{array}$ & 2 & $\begin{array}{l}43.659107^{\circ}, \\
-79.446496^{\circ} \\
\end{array}$ & $\begin{array}{l}\text { In front of } \\
\text { housing }\end{array}$ & $\begin{array}{l}\text { Semi-detached home. } \\
\text { Renovation status unclear. }\end{array}$ \\
\hline English Oak & Quercus robur & defoliation & 1 & $\begin{array}{l}43.659533^{\circ}, \\
-79.446685^{\circ}\end{array}$ & $\begin{array}{l}\text { In front of } \\
\text { housing }\end{array}$ & $\begin{array}{l}\text { Semi-detached home. } \\
\text { Renovation status unclear. }\end{array}$ \\
\hline English Oak & Quercus robur & small cracks on trunk & 1 & $\begin{array}{l}43.659550^{\circ}, \\
-79.446695^{\circ}\end{array}$ & $\begin{array}{l}\text { In front of } \\
\text { housing }\end{array}$ & $\begin{array}{l}\text { Semi-detached home. } \\
\text { Renovation status unclear. }\end{array}$ \\
\hline English Oak & Quercus robur & $\begin{array}{l}\text { good condition. Has been } \\
\text { pruned, new shoots } \\
\text { forming. }\end{array}$ & 0 & $\begin{array}{l}43.659720^{\circ} \\
-79.446762^{\circ}\end{array}$ & $\begin{array}{l}\text { In front of } \\
\text { housing }\end{array}$ & $\begin{array}{l}\text { Semi-detached home. } \\
\text { Renovation status unclear. }\end{array}$ \\
\hline $\begin{array}{l}\text { European } \\
\text { Beech }\end{array}$ & Fagus sylvatica & good condition & 0 & $\begin{array}{l}43.660236^{\circ} \\
-79.450316^{\circ}\end{array}$ & $\begin{array}{l}\text { In front of } \\
\text { housing }\end{array}$ & $\begin{array}{l}\text { New tree. Improved semi- } \\
\text { detached home. }\end{array}$ \\
\hline $\begin{array}{l}\text { Freeman } \\
\text { Maple }\end{array}$ & $\begin{array}{l}\text { Acer } \mathrm{x} \\
\text { freemanii }\end{array}$ & peeling bark & 1 & $\begin{array}{l}43.660110^{\circ} \\
-79.450014^{\circ}\end{array}$ & $\begin{array}{l}\text { In front of } \\
\text { housing }\end{array}$ & $\begin{array}{l}\text { New tree. Improved semi- } \\
\text { detached home. }\end{array}$ \\
\hline $\begin{array}{l}\text { Freeman } \\
\text { Maple }\end{array}$ & $\begin{array}{l}\text { Acer } x \\
\text { freemanii }\end{array}$ & good condition & 0 & $\begin{array}{l}43.660740^{\circ}, \\
-79.451593^{\circ}\end{array}$ & $\begin{array}{l}\text { In front of } \\
\text { housing }\end{array}$ & $\begin{array}{l}\text { New tree. Stacked } \\
\text { townhome. }\end{array}$ \\
\hline $\begin{array}{l}\text { Freeman } \\
\text { Maple }\end{array}$ & $\begin{array}{l}\text { Acer } \mathrm{x} \\
\text { freemanii }\end{array}$ & good condition & 0 & $\begin{array}{l}43.660759^{\circ} \\
-79.451483^{\circ}\end{array}$ & $\begin{array}{l}\text { In front of } \\
\text { housing }\end{array}$ & $\begin{array}{l}\text { New tree. Stacked } \\
\text { townhome. }\end{array}$ \\
\hline $\begin{array}{l}\text { Freeman } \\
\text { Maple }\end{array}$ & $\begin{array}{l}\text { Acer } \mathrm{x} \\
\text { freemanii }\end{array}$ & good condition & 0 & $\begin{array}{l}43.660785^{\circ}, \\
-79.451400^{\circ}\end{array}$ & $\begin{array}{l}\text { In front of } \\
\text { housing }\end{array}$ & $\begin{array}{l}\text { New tree. Stacked } \\
\text { townhome. }\end{array}$ \\
\hline $\begin{array}{l}\text { Freeman } \\
\text { Maple }\end{array}$ & $\begin{array}{l}\text { Acer } \mathrm{x} \\
\text { freemanii }\end{array}$ & small cankers on trunk & 1 & $\begin{array}{l}43.659733^{\circ}, \\
-79.449091^{\circ}\end{array}$ & $\begin{array}{l}\text { In front of } \\
\text { housing }\end{array}$ & $\begin{array}{l}\text { Improved semi-detached } \\
\text { home. }\end{array}$ \\
\hline Ginkgo & Ginkgo biloba & cracks on bark & 1 & $\begin{array}{l}43.659281^{\circ} \\
-79.447417^{\circ}\end{array}$ & $\begin{array}{l}\text { In front of } \\
\text { housing }\end{array}$ & $\begin{array}{l}\text { New tree. Unimproved semi- } \\
\text { detached home. }\end{array}$ \\
\hline Ginkgo & Ginkgo biloba & good condition & 0 & $\begin{array}{l}43.658519^{\circ} \\
-79.447102^{\circ}\end{array}$ & $\begin{array}{l}\text { In front of } \\
\text { housing }\end{array}$ & $\begin{array}{l}\text { New tree. Improved semi- } \\
\text { detached home. }\end{array}$ \\
\hline Ginkgo & Ginkgo biloba & good condition & 0 & $\begin{array}{l}43.659252^{\circ} \\
-79.447621^{\circ}\end{array}$ & $\begin{array}{l}\text { In front of } \\
\text { housing }\end{array}$ & $\begin{array}{l}\text { New tree. Improved semi- } \\
\text { detached home. }\end{array}$ \\
\hline Ginkgo & Ginkgo biloba & good condition & 0 & $\begin{array}{l}43.659262^{\circ}, \\
-79.448416^{\circ} \\
\end{array}$ & $\begin{array}{l}\text { In front of } \\
\text { housing }\end{array}$ & $\begin{array}{l}\text { New tree. Improved semi- } \\
\text { detached home. }\end{array}$ \\
\hline Ginkgo & Ginkgo biloba & good condition & 0 & $\begin{array}{l}43.660106^{\circ}, \\
-79.447950^{\circ}\end{array}$ & $\begin{array}{l}\text { In front of } \\
\text { housing }\end{array}$ & $\begin{array}{l}\text { New tree. Improved semi- } \\
\text { detached home. }\end{array}$ \\
\hline Ginkgo & Ginkgo biloba & good condition & 0 & $\begin{array}{l}43.660899^{\circ}, \\
-79.449342^{\circ}\end{array}$ & $\begin{array}{l}\text { In front of } \\
\text { housing }\end{array}$ & $\begin{array}{l}\text { New tree. Improved semi- } \\
\text { detached home. }\end{array}$ \\
\hline Ginkgo & Ginkgo biloba & good condition & 0 & $\begin{array}{l}43.657826^{\circ} \\
-79.447837^{\circ} \\
\end{array}$ & $\begin{array}{l}\text { In front of } \\
\text { housing }\end{array}$ & New tree. Row home. \\
\hline Ginkgo & Ginkgo biloba & cracks on trunk & 1 & $\begin{array}{l}43.660013^{\circ} \\
-79.451242^{\circ}\end{array}$ & $\begin{array}{l}\text { In front of } \\
\text { housing }\end{array}$ & $\begin{array}{l}\text { New tree. Stacked } \\
\text { townhome. }\end{array}$ \\
\hline
\end{tabular}




\begin{tabular}{|c|c|c|c|c|c|c|}
\hline Ginkgo & Ginkgo biloba & cracks on trunk & 1 & $\begin{array}{l}43.660077^{\circ}, \\
-79.451281^{\circ}\end{array}$ & $\begin{array}{l}\text { In front of } \\
\text { housing }\end{array}$ & $\begin{array}{l}\text { New tree. Stacked } \\
\text { townhome. }\end{array}$ \\
\hline Ginkgo & Ginkgo biloba & cracks on trunk & 1 & $\begin{array}{l}43.660110^{\circ}, \\
-79.451285^{\circ}\end{array}$ & $\begin{array}{l}\text { In front of } \\
\text { housing }\end{array}$ & $\begin{array}{l}\text { New tree. Stacked } \\
\text { townhome. }\end{array}$ \\
\hline Ginkgo & Ginkgo biloba & good condition & 0 & $\begin{array}{l}43.660288^{\circ}, \\
-79.451634^{\circ}\end{array}$ & $\begin{array}{l}\text { In front of } \\
\text { housing }\end{array}$ & $\begin{array}{l}\text { New tree. Stacked } \\
\text { townhome. }\end{array}$ \\
\hline Ginkgo & Ginkgo biloba & good condition & 0 & $\begin{array}{l}43.660471^{\circ}, \\
-79.451702^{\circ}\end{array}$ & $\begin{array}{l}\text { In front of } \\
\text { housing }\end{array}$ & $\begin{array}{l}\text { New tree. Stacked } \\
\text { townhome. }\end{array}$ \\
\hline Ginkgo & Ginkgo biloba & good condition & 0 & $\begin{array}{l}43.659320^{\circ}, \\
-79.449742^{\circ}\end{array}$ & $\begin{array}{l}\text { In front of } \\
\text { housing }\end{array}$ & $\begin{array}{l}\text { Improved semi-detached } \\
\text { home. }\end{array}$ \\
\hline Green Ash & $\begin{array}{l}\text { Fraxinus } \\
\text { pennsylvanica }\end{array}$ & good condition & 0 & $\begin{array}{l}43.657604^{\circ}, \\
-79.449202^{\circ}\end{array}$ & $\begin{array}{l}\text { In front of } \\
\text { housing }\end{array}$ & Low-rise apartment. \\
\hline Green Ash & $\begin{array}{l}\text { Fraxinus } \\
\text { pennsylvanica }\end{array}$ & peeling bark, small cracks & 1 & $\begin{array}{l}43.658536^{\circ}, \\
-79.450161^{\circ}\end{array}$ & $\begin{array}{l}\text { In front of } \\
\text { housing }\end{array}$ & Low-rise apartment. \\
\hline Green Ash & $\begin{array}{l}\text { Fraxinus } \\
\text { pennsylvanica }\end{array}$ & $\begin{array}{l}\text { tree lean, defoliation, } \\
\text { dead/broken branches }\end{array}$ & 2 & $\begin{array}{l}43.658561^{\circ}, \\
-79.449981^{\circ}\end{array}$ & $\begin{array}{l}\text { In front of } \\
\text { housing }\end{array}$ & Low-rise apartment. \\
\hline Green Ash & $\begin{array}{l}\text { Fraxinus } \\
\text { pennsylvanica }\end{array}$ & tree lean & 1 & $\begin{array}{l}43.658603^{\circ}, \\
-79.449831^{\circ}\end{array}$ & $\begin{array}{l}\text { In front of } \\
\text { housing }\end{array}$ & Low-rise apartment. \\
\hline Green Ash & $\begin{array}{l}\text { Fraxinus } \\
\text { pennsylvanica }\end{array}$ & good condition & 0 & $\begin{array}{l}43.661055^{\circ}, \\
-79.448106^{\circ}\end{array}$ & $\begin{array}{l}\text { In front of } \\
\text { housing }\end{array}$ & $\begin{array}{l}\text { Unimproved semi-detached } \\
\text { home. }\end{array}$ \\
\hline Green Ash & $\begin{array}{l}\text { Fraxinus } \\
\text { pennsylvanica }\end{array}$ & good condition & 0 & $\begin{array}{l}43.657809^{\circ}, \\
-79.448080^{\circ}\end{array}$ & $\begin{array}{l}\text { In front of } \\
\text { housing }\end{array}$ & $\begin{array}{l}\text { Improved semi-detached } \\
\text { home. }\end{array}$ \\
\hline Green Ash & $\begin{array}{l}\text { Fraxinus } \\
\text { pennsylvanica }\end{array}$ & small cracks on trunk & 1 & $\begin{array}{l}43.658583^{\circ}, \\
-79.448153^{\circ}\end{array}$ & $\begin{array}{l}\text { In front of } \\
\text { housing }\end{array}$ & $\begin{array}{l}\text { Improved semi-detached } \\
\text { home. }\end{array}$ \\
\hline Green Ash & $\begin{array}{l}\text { Fraxinus } \\
\text { pennsylvanica }\end{array}$ & cracks on bark & 1 & $\begin{array}{l}43.659614^{\circ}, \\
-79.449816^{\circ}\end{array}$ & $\begin{array}{l}\text { In front of } \\
\text { housing }\end{array}$ & $\begin{array}{l}\text { Improved semi-detached } \\
\text { home. }\end{array}$ \\
\hline Green Ash & $\begin{array}{l}\text { Fraxinus } \\
\text { pennsylvanica }\end{array}$ & $10 \%$ dieback & 1 & $\begin{array}{l}43.660713^{\circ}, \\
-79.448243^{\circ}\end{array}$ & $\begin{array}{l}\text { In front of } \\
\text { housing }\end{array}$ & $\begin{array}{l}\text { Improved semi-detached } \\
\text { home. }\end{array}$ \\
\hline Green Ash & $\begin{array}{l}\text { Fraxinus } \\
\text { pennsylvanica }\end{array}$ & cracks on trunk, tree lean & 2 & $\begin{array}{l}43.658032^{\circ}, \\
-79.449412^{\circ}\end{array}$ & $\begin{array}{l}\text { In front of } \\
\text { housing }\end{array}$ & Stacked townhome. \\
\hline Green Ash & $\begin{array}{l}\text { Fraxinus } \\
\text { pennsylvanica }\end{array}$ & $\begin{array}{l}\text { cranks and cankers on } \\
\text { trunk, tree lean, weak } \\
\text { branch union }\end{array}$ & 3 & $\begin{array}{l}43.658080^{\circ}, \\
-79.449450^{\circ}\end{array}$ & $\begin{array}{l}\text { In front of } \\
\text { housing }\end{array}$ & Stacked townhome. \\
\hline Green Ash & $\begin{array}{l}\text { Fraxinus } \\
\text { pennsylvanica }\end{array}$ & $\begin{array}{l}\text { tree lean, small cracks on } \\
\text { trunk }\end{array}$ & 2 & $\begin{array}{l}43.658264^{\circ}, \\
-79.449509^{\circ}\end{array}$ & $\begin{array}{l}\text { In front of } \\
\text { housing }\end{array}$ & Stacked townhome. \\
\hline Green Ash & $\begin{array}{l}\text { Fraxinus } \\
\text { pennsylvanica }\end{array}$ & $\begin{array}{l}\text { tree lean, } 20 \% \text { dieback, } \\
\text { small cracks on trunk }\end{array}$ & 2 & $\begin{array}{l}43.658335^{\circ}, \\
-79.449531^{\circ}\end{array}$ & $\begin{array}{l}\text { In front of } \\
\text { housing }\end{array}$ & Stacked townhome. \\
\hline Green Ash & $\begin{array}{l}\text { Fraxinus } \\
\text { pennsylvanica }\end{array}$ & $\begin{array}{l}\text { tree lean, } 20 \% \text { dieback, } \\
\text { weak branch unions, cracks } \\
\text { and peeling bark }\end{array}$ & 3 & $\begin{array}{l}43.658430^{\circ} \\
-79.449580^{\circ}\end{array}$ & $\begin{array}{l}\text { In front of } \\
\text { housing }\end{array}$ & Stacked townhome. \\
\hline $\begin{array}{l}\text { Honey } \\
\text { Locust }\end{array}$ & $\begin{array}{l}\text { Gleditsia } \\
\text { triacanthos }\end{array}$ & $\begin{array}{l}\text { cracks, peeling bark, weak } \\
\text { branch unions, } 20 \% \\
\text { dieback }\end{array}$ & 3 & $\begin{array}{l}43.657334^{\circ} \\
-79.449512^{\circ}\end{array}$ & $\begin{array}{l}\text { In front of } \\
\text { housing }\end{array}$ & Low-rise apartment. \\
\hline $\begin{array}{l}\text { Honey } \\
\text { Locust }\end{array}$ & $\begin{array}{l}\text { Gleditsia } \\
\text { triacanthos }\end{array}$ & $30 \%$ Dieback & 1 & $\begin{array}{l}43.657338^{\circ}, \\
-79.449562^{\circ}\end{array}$ & $\begin{array}{l}\text { In front of } \\
\text { housing }\end{array}$ & Low-rise apartment. \\
\hline $\begin{array}{l}\text { Honey } \\
\text { Locust }\end{array}$ & $\begin{array}{l}\text { Gleditsia } \\
\text { triacanthos }\end{array}$ & $\begin{array}{l}\text { cracks, cankers, } 80 \% \\
\text { Dieback }\end{array}$ & 3 & $\begin{array}{l}43.657685^{\circ}, \\
-79.449858^{\circ}\end{array}$ & $\begin{array}{l}\text { In front of } \\
\text { housing }\end{array}$ & Low-rise apartment. \\
\hline $\begin{array}{l}\text { Honey } \\
\text { Locust }\end{array}$ & $\begin{array}{l}\text { Gleditsia } \\
\text { triacanthos }\end{array}$ & good condition & 0 & $\begin{array}{l}43.660038^{\circ}, \\
-79.452209^{\circ}\end{array}$ & $\begin{array}{l}\text { In front of } \\
\text { housing }\end{array}$ & $\begin{array}{l}\text { New tree. Low-rise } \\
\text { apartment. }\end{array}$ \\
\hline $\begin{array}{l}\text { Honey } \\
\text { Locust }\end{array}$ & $\begin{array}{l}\text { Gleditsia } \\
\text { triacanthos }\end{array}$ & good condition & 0 & $\begin{array}{l}43.660051^{\circ}, \\
-79.452121^{\circ}\end{array}$ & $\begin{array}{l}\text { In front of } \\
\text { housing }\end{array}$ & $\begin{array}{l}\text { New tree. Low-rise } \\
\text { apartment. }\end{array}$ \\
\hline $\begin{array}{l}\text { Honey } \\
\text { Locust }\end{array}$ & $\begin{array}{l}\text { Gleditsia } \\
\text { triacanthos }\end{array}$ & good condition & 0 & $\begin{array}{l}43.660069^{\circ}, \\
-79.452035^{\circ}\end{array}$ & $\begin{array}{l}\text { In front of } \\
\text { housing }\end{array}$ & $\begin{array}{l}\text { New tree. Low-rise } \\
\text { apartment. }\end{array}$ \\
\hline $\begin{array}{l}\text { Honey } \\
\text { Locust }\end{array}$ & $\begin{array}{l}\text { Gleditsia } \\
\text { triacanthos }\end{array}$ & good condition & 0 & $\begin{array}{l}43.660111^{\circ}, \\
-79.451988^{\circ}\end{array}$ & $\begin{array}{l}\text { In front of } \\
\text { housing }\end{array}$ & $\begin{array}{l}\text { New tree. Low-rise } \\
\text { apartment. }\end{array}$ \\
\hline $\begin{array}{l}\text { Honey } \\
\text { Locust }\end{array}$ & $\begin{array}{l}\text { Gleditsia } \\
\text { triacanthos }\end{array}$ & good condition & 0 & $\begin{array}{l}43.660173^{\circ}, \\
-79.452001^{\circ}\end{array}$ & $\begin{array}{l}\text { In front of } \\
\text { housing }\end{array}$ & $\begin{array}{l}\text { New tree. Low-rise } \\
\text { apartment. }\end{array}$ \\
\hline $\begin{array}{l}\text { Honey } \\
\text { Locust }\end{array}$ & $\begin{array}{l}\text { Gleditsia } \\
\text { triacanthos }\end{array}$ & good condition & 0 & $\begin{array}{l}43.660229^{\circ}, \\
-79.452021^{\circ}\end{array}$ & $\begin{array}{l}\text { In front of } \\
\text { housing }\end{array}$ & $\begin{array}{l}\text { New tree. Low-rise } \\
\text { apartment. }\end{array}$ \\
\hline $\begin{array}{l}\text { Honey } \\
\text { Locust }\end{array}$ & $\begin{array}{l}\text { Gleditsia } \\
\text { triacanthos }\end{array}$ & good condition & 0 & $\begin{array}{l}43.660287^{\circ}, \\
-79.452048^{\circ}\end{array}$ & $\begin{array}{l}\text { In front of } \\
\text { housing }\end{array}$ & $\begin{array}{l}\text { New tree. Low-rise } \\
\text { apartment. }\end{array}$ \\
\hline $\begin{array}{l}\text { Honey } \\
\text { Locust }\end{array}$ & $\begin{array}{l}\text { Gleditsia } \\
\text { triacanthos }\end{array}$ & good condition & 0 & $\begin{array}{l}43.660341^{\circ}, \\
-79.452074^{\circ}\end{array}$ & $\begin{array}{l}\text { In front of } \\
\text { housing }\end{array}$ & $\begin{array}{l}\text { New tree. Low-rise } \\
\text { apartment. }\end{array}$ \\
\hline $\begin{array}{l}\text { Honey } \\
\text { Locust }\end{array}$ & $\begin{array}{l}\text { Gleditsia } \\
\text { triacanthos }\end{array}$ & good condition & 0 & $\begin{array}{l}43.660414^{\circ}, \\
-79.452096^{\circ}\end{array}$ & $\begin{array}{l}\text { In front of } \\
\text { housing }\end{array}$ & $\begin{array}{l}\text { New tree. Low-rise } \\
\text { apartment. }\end{array}$ \\
\hline $\begin{array}{l}\text { Honey } \\
\text { Locust }\end{array}$ & $\begin{array}{l}\text { Gleditsia } \\
\text { triacanthos }\end{array}$ & good condition & 0 & $\begin{array}{l}43.660475^{\circ}, \\
-79.452119^{\circ}\end{array}$ & $\begin{array}{l}\text { In front of } \\
\text { housing }\end{array}$ & $\begin{array}{l}\text { New tree. Low-rise } \\
\text { apartment. }\end{array}$ \\
\hline
\end{tabular}




\begin{tabular}{|c|c|c|c|c|c|c|}
\hline $\begin{array}{l}\text { Honey } \\
\text { Locust }\end{array}$ & $\begin{array}{l}\text { Gleditsia } \\
\text { triacanthos }\end{array}$ & good condition & 0 & $\begin{array}{l}43.660514^{\circ}, \\
-79.452138^{\circ}\end{array}$ & $\begin{array}{l}\text { In front of } \\
\text { housing }\end{array}$ & $\begin{array}{l}\text { New tree. Low-rise } \\
\text { apartment. }\end{array}$ \\
\hline $\begin{array}{l}\text { Honey } \\
\text { Locust }\end{array}$ & $\begin{array}{l}\text { Gleditsia } \\
\text { triacanthos }\end{array}$ & good condition & 0 & $\begin{array}{l}43.660554^{\circ}, \\
-79.452152^{\circ}\end{array}$ & $\begin{array}{l}\text { In front of } \\
\text { housing }\end{array}$ & $\begin{array}{l}\text { New tree. Low-rise } \\
\text { apartment. }\end{array}$ \\
\hline $\begin{array}{l}\text { Honey } \\
\text { Locust }\end{array}$ & $\begin{array}{l}\text { Ailanthus } \\
\text { altissima }\end{array}$ & peeling bark & 1 & $\begin{array}{l}43.658310^{\circ}, \\
-79.448273^{\circ}\end{array}$ & $\begin{array}{l}\text { In front of } \\
\text { housing }\end{array}$ & $\begin{array}{l}\text { New tree. Improved semi- } \\
\text { detached home. }\end{array}$ \\
\hline $\begin{array}{l}\text { Honey } \\
\text { Locust }\end{array}$ & $\begin{array}{l}\text { Gleditsia } \\
\text { triacanthos }\end{array}$ & good condition & 0 & $\begin{array}{l}43.658566^{\circ}, \\
-79.448371^{\circ}\end{array}$ & $\begin{array}{l}\text { In front of } \\
\text { housing }\end{array}$ & $\begin{array}{l}\text { New tree. Improved semi- } \\
\text { detached home. }\end{array}$ \\
\hline $\begin{array}{l}\text { Honey } \\
\text { Locust }\end{array}$ & $\begin{array}{l}\text { Gleditsia } \\
\text { triacanthos }\end{array}$ & good condition & 0 & $\begin{array}{l}43.659376^{\circ} \\
-79.446618^{\circ}\end{array}$ & $\begin{array}{l}\text { In front of } \\
\text { housing }\end{array}$ & $\begin{array}{l}\text { New tree. Improved semi- } \\
\text { detached home. }\end{array}$ \\
\hline $\begin{array}{l}\text { Honey } \\
\text { Locust }\end{array}$ & $\begin{array}{l}\text { Gleditsia } \\
\text { triacanthos }\end{array}$ & tree lean, cracks on trunk & 2 & $\begin{array}{l}43.660363^{\circ} \\
-79.450351^{\circ}\end{array}$ & $\begin{array}{l}\text { In front of } \\
\text { housing }\end{array}$ & $\begin{array}{l}\text { New tree. Improved semi- } \\
\text { detached home. }\end{array}$ \\
\hline $\begin{array}{l}\text { Honey } \\
\text { Locust }\end{array}$ & $\begin{array}{l}\text { Gleditsia } \\
\text { triacanthos }\end{array}$ & good condition & 0 & $\begin{array}{l}43.660491^{\circ}, \\
-79.447913^{\circ}\end{array}$ & $\begin{array}{l}\text { In front of } \\
\text { housing }\end{array}$ & $\begin{array}{l}\text { New tree. Improved semi- } \\
\text { detached home. }\end{array}$ \\
\hline $\begin{array}{l}\text { Honey } \\
\text { Locust }\end{array}$ & $\begin{array}{l}\text { Gleditsia } \\
\text { triacanthos }\end{array}$ & good condition. & 0 & $\begin{array}{l}43.659638^{\circ}, \\
-79.446707^{\circ}\end{array}$ & $\begin{array}{l}\text { In front of } \\
\text { housing }\end{array}$ & $\begin{array}{l}\text { New tree. Semi-detached } \\
\text { home. Renovation status } \\
\text { unclear. }\end{array}$ \\
\hline $\begin{array}{l}\text { Honey } \\
\text { Locust }\end{array}$ & $\begin{array}{l}\text { Gleditsia } \\
\text { triacanthos }\end{array}$ & good condition & 0 & $\begin{array}{l}43.661700^{\circ} \\
-79.447047^{\circ}\end{array}$ & $\begin{array}{l}\text { In front of } \\
\text { housing }\end{array}$ & $\begin{array}{l}\text { New tree. Semi-detached } \\
\text { home. Renovation status } \\
\text { unclear. }\end{array}$ \\
\hline $\begin{array}{l}\text { Honey } \\
\text { Locust }\end{array}$ & $\begin{array}{l}\text { Gleditsia } \\
\text { triacanthos }\end{array}$ & $\begin{array}{l}\text { cracks on trunk, defoliation, } \\
\text { weak branch unions }\end{array}$ & 2 & $\begin{array}{l}43.659589^{\circ}, \\
-79.449354^{\circ}\end{array}$ & $\begin{array}{l}\text { In front of } \\
\text { housing }\end{array}$ & $\begin{array}{l}\text { Unimproved semi-detached } \\
\text { home. }\end{array}$ \\
\hline $\begin{array}{l}\text { Honey } \\
\text { Locust }\end{array}$ & $\begin{array}{l}\text { Gleditsia } \\
\text { triacanthos }\end{array}$ & tree lean, cracks on trunk & 1 & $\begin{array}{l}43.659921^{\circ}, \\
-79.447311^{\circ}\end{array}$ & $\begin{array}{l}\text { In front of } \\
\text { housing }\end{array}$ & $\begin{array}{l}\text { Unimproved semi-detached } \\
\text { home. }\end{array}$ \\
\hline $\begin{array}{l}\text { Honey } \\
\text { Locust }\end{array}$ & $\begin{array}{l}\text { Gleditsia } \\
\text { triacanthos }\end{array}$ & peeling bark & 1 & $\begin{array}{l}43.657440^{\circ}, \\
-79.448935^{\circ}\end{array}$ & $\begin{array}{l}\text { In front of } \\
\text { housing }\end{array}$ & $\begin{array}{l}\text { Improved semi-detached } \\
\text { home. }\end{array}$ \\
\hline $\begin{array}{l}\text { Honey } \\
\text { Locust }\end{array}$ & $\begin{array}{l}\text { Gleditsia } \\
\text { triacanthos }\end{array}$ & small cracks on trunk & 1 & $\begin{array}{l}43.657736^{\circ}, \\
-79.449069^{\circ}\end{array}$ & $\begin{array}{l}\text { In front of } \\
\text { housing }\end{array}$ & $\begin{array}{l}\text { Improved semi-detached } \\
\text { home. }\end{array}$ \\
\hline $\begin{array}{l}\text { Honey } \\
\text { Locust }\end{array}$ & $\begin{array}{l}\text { Gleditsia } \\
\text { triacanthos }\end{array}$ & $\begin{array}{l}\text { cracks on trunk, peeling } \\
\text { bark }\end{array}$ & 2 & $\begin{array}{l}43.658518^{\circ} \\
-79.447279^{\circ}\end{array}$ & $\begin{array}{l}\text { In front of } \\
\text { housing }\end{array}$ & $\begin{array}{l}\text { Improved semi-detached } \\
\text { home. }\end{array}$ \\
\hline $\begin{array}{l}\text { Honey } \\
\text { Locust }\end{array}$ & $\begin{array}{l}\text { Gleditsia } \\
\text { triacanthos }\end{array}$ & dead/broken branches & 1 & $\begin{array}{l}43.658545^{\circ}, \\
-79.449423^{\circ}\end{array}$ & $\begin{array}{l}\text { In front of } \\
\text { housing }\end{array}$ & $\begin{array}{l}\text { Improved semi-detached } \\
\text { home. }\end{array}$ \\
\hline $\begin{array}{l}\text { Honey } \\
\text { Locust }\end{array}$ & $\begin{array}{l}\text { Gleditsia } \\
\text { triacanthos }\end{array}$ & cankers on trunk & 1 & $\begin{array}{l}43.658917^{\circ}, \\
-79.449572^{\circ}\end{array}$ & $\begin{array}{l}\text { In front of } \\
\text { housing }\end{array}$ & $\begin{array}{l}\text { Improved semi-detached } \\
\text { home. }\end{array}$ \\
\hline $\begin{array}{l}\text { Honey } \\
\text { Locust }\end{array}$ & $\begin{array}{l}\text { Gleditsia } \\
\text { triacanthos }\end{array}$ & peeling bark & 1 & $\begin{array}{l}43.659899^{\circ}, \\
-79.447362^{\circ}\end{array}$ & $\begin{array}{l}\text { In front of } \\
\text { housing }\end{array}$ & $\begin{array}{l}\text { Improved semi-detached } \\
\text { home. }\end{array}$ \\
\hline $\begin{array}{l}\text { Honey } \\
\text { Locust }\end{array}$ & $\begin{array}{l}\text { Gleditsia } \\
\text { triacanthos }\end{array}$ & $\begin{array}{l}\text { cracks on trunk, peeling } \\
\text { bark }\end{array}$ & 2 & $\begin{array}{l}43.660425^{\circ} \\
-79.450167^{\circ}\end{array}$ & $\begin{array}{l}\text { In front of } \\
\text { housing }\end{array}$ & $\begin{array}{l}\text { Improved semi-detached } \\
\text { home. }\end{array}$ \\
\hline $\begin{array}{l}\text { Honey } \\
\text { Locust }\end{array}$ & $\begin{array}{l}\text { Gleditsia } \\
\text { triacanthos }\end{array}$ & peeling bark & 1 & $\begin{array}{l}43.661325^{\circ}, \\
-79.448734^{\circ}\end{array}$ & $\begin{array}{l}\text { In front of } \\
\text { housing }\end{array}$ & $\begin{array}{l}\text { Improved semi-detached } \\
\text { home. }\end{array}$ \\
\hline $\begin{array}{l}\text { Japanese } \\
\text { Cherry }\end{array}$ & $\begin{array}{l}\text { Prunus } \\
\text { serrulata }\end{array}$ & cracks on trunk & 1 & $\begin{array}{l}43.660012^{\circ}, \\
-79.450924^{\circ}\end{array}$ & $\begin{array}{l}\text { In front of } \\
\text { housing }\end{array}$ & $\begin{array}{l}\text { New tree. Stacked } \\
\text { townhome. }\end{array}$ \\
\hline $\begin{array}{l}\text { Japanese } \\
\text { Katsura }\end{array}$ & $\begin{array}{l}\text { Cercidiphyllu } \\
\text { m japonicum }\end{array}$ & good condition & 0 & $\begin{array}{l}43.659542^{\circ}, \\
-79.448424^{\circ}\end{array}$ & $\begin{array}{l}\text { In front of } \\
\text { housing }\end{array}$ & $\begin{array}{l}\text { New tree. Improved semi- } \\
\text { detached home. }\end{array}$ \\
\hline $\begin{array}{l}\text { Japanese } \\
\text { Katsura }\end{array}$ & $\begin{array}{l}\text { Cercidiphyllu } \\
\text { m japonicum }\end{array}$ & tree lean & 1 & $\begin{array}{l}43.659823^{\circ}, \\
-79.450123^{\circ}\end{array}$ & $\begin{array}{l}\text { In front of } \\
\text { housing }\end{array}$ & $\begin{array}{l}\text { New tree. Improved semi- } \\
\text { detached home. }\end{array}$ \\
\hline $\begin{array}{l}\text { Japanese } \\
\text { Katsura }\end{array}$ & $\begin{array}{l}\text { Cercidiphyllu } \\
\mathrm{m} \text { japonicum }\end{array}$ & good condition & 0 & $\begin{array}{l}43.660066^{\circ}, \\
-79.450023^{\circ}\end{array}$ & $\begin{array}{l}\text { In front of } \\
\text { housing }\end{array}$ & $\begin{array}{l}\text { New tree. Improved semi- } \\
\text { detached home. }\end{array}$ \\
\hline $\begin{array}{l}\text { Japanese } \\
\text { Katsura }\end{array}$ & $\begin{array}{l}\text { Cercidiphyllu } \\
\text { m japonicum }\end{array}$ & defoliation & 1 & $\begin{array}{l}43.660121^{\circ}, \\
-79.450008^{\circ}\end{array}$ & $\begin{array}{l}\text { In front of } \\
\text { housing }\end{array}$ & $\begin{array}{l}\text { New tree. Improved semi- } \\
\text { detached home. }\end{array}$ \\
\hline $\begin{array}{l}\text { Japanese } \\
\text { Maple }\end{array}$ & Acer palmatum & good condition & 0 & $\begin{array}{l}43.659125^{\circ}, \\
-79.449664^{\circ}\end{array}$ & $\begin{array}{l}\text { In front of } \\
\text { housing }\end{array}$ & $\begin{array}{l}\text { New tree. Improved semi- } \\
\text { detached home. }\end{array}$ \\
\hline $\begin{array}{l}\text { Japanese } \\
\text { Maple }\end{array}$ & Acer palmatum & good condition & 0 & $\begin{array}{l}43.659196^{\circ}, \\
-79.448649^{\circ}\end{array}$ & $\begin{array}{l}\text { In front of } \\
\text { housing }\end{array}$ & $\begin{array}{l}\text { New tree. Improved semi- } \\
\text { detached home. }\end{array}$ \\
\hline $\begin{array}{l}\text { Japanese } \\
\text { Maple }\end{array}$ & Acer palmatum & defoliation & 1 & $\begin{array}{l}43.660458^{\circ}, \\
-79.449139^{\circ}\end{array}$ & $\begin{array}{l}\text { In front of } \\
\text { housing }\end{array}$ & $\begin{array}{l}\text { New tree. Improved semi- } \\
\text { detached home. }\end{array}$ \\
\hline $\begin{array}{l}\text { Japanese } \\
\text { Maple }\end{array}$ & Acer palmatum & good condition & 0 & $\begin{array}{l}43.660484^{\circ}, \\
-79.450210^{\circ}\end{array}$ & $\begin{array}{l}\text { In front of } \\
\text { housing }\end{array}$ & $\begin{array}{l}\text { New tree. Improved semi- } \\
\text { detached home. }\end{array}$ \\
\hline $\begin{array}{l}\text { Japanese } \\
\text { Maple }\end{array}$ & Acer palmatum & discoloured leaves & 1 & $\begin{array}{l}43.661104^{\circ}, \\
-79.448355^{\circ}\end{array}$ & $\begin{array}{l}\text { In front of } \\
\text { housing }\end{array}$ & $\begin{array}{l}\text { New tree. Improved semi- } \\
\text { detached home. }\end{array}$ \\
\hline $\begin{array}{l}\text { Japanese } \\
\text { Maple }\end{array}$ & Acer palmatum & good condition & 0 & $\begin{array}{l}43.659647^{\circ}, \\
-79.449672^{\circ}\end{array}$ & $\begin{array}{l}\text { In front of } \\
\text { housing }\end{array}$ & $\begin{array}{l}\text { Improved semi-detached } \\
\text { home. }\end{array}$ \\
\hline $\begin{array}{l}\text { Japanese } \\
\text { Maple }\end{array}$ & Acer palmatum & $\begin{array}{l}\text { defoliation, discoloured } \\
\text { leaves }\end{array}$ & 2 & $\begin{array}{l}43.660666^{\circ}, \\
-79.450525^{\circ}\end{array}$ & $\begin{array}{l}\text { In front of } \\
\text { housing }\end{array}$ & $\begin{array}{l}\text { Improved semi-detached } \\
\text { home. }\end{array}$ \\
\hline $\begin{array}{l}\text { Japanese } \\
\text { Maple }\end{array}$ & Acer palmatum & defoliation & 1 & $\begin{array}{l}43.659627^{\circ}, \\
-79.446783^{\circ}\end{array}$ & $\begin{array}{l}\text { In front of } \\
\text { housing }\end{array}$ & $\begin{array}{l}\text { Semi-detached home. } \\
\text { Renovation status unclear. }\end{array}$ \\
\hline $\begin{array}{l}\text { Japanese } \\
\text { Maple }\end{array}$ & Acer palmatum & $20 \%$ dieback, cracks & 2 & $\begin{array}{l}43.660753^{\circ}, \\
-79.447187^{\circ}\end{array}$ & $\begin{array}{l}\text { In front of } \\
\text { housing }\end{array}$ & $\begin{array}{l}\text { Semi-detached home. } \\
\text { Renovation status unclear. }\end{array}$ \\
\hline
\end{tabular}




\begin{tabular}{|c|c|c|c|c|c|c|}
\hline $\begin{array}{l}\text { Japanese } \\
\text { Maple }\end{array}$ & Acer palmatum & good condition & 0 & $\begin{array}{l}43.660811^{\circ} \\
-79.448274^{\circ}\end{array}$ & $\begin{array}{l}\text { In front of } \\
\text { housing }\end{array}$ & $\begin{array}{l}\text { New tree. Improved semi- } \\
\text { detached home. }\end{array}$ \\
\hline $\begin{array}{l}\text { Japenese } \\
\text { Maple }\end{array}$ & Acer palmatum & good condition & 0 & $\begin{array}{l}43.659749^{\circ}, \\
-79.450129^{\circ}\end{array}$ & $\begin{array}{l}\text { In front of } \\
\text { housing }\end{array}$ & $\begin{array}{l}\text { New tree. Improved semi- } \\
\text { detached home. }\end{array}$ \\
\hline $\begin{array}{l}\text { Kentucky } \\
\text { Coffeetree }\end{array}$ & $\begin{array}{l}\text { Gymnocladus } \\
\text { dioicus }\end{array}$ & good condition & 1 & $\begin{array}{l}43.660697^{\circ} \\
-79.450301^{\circ}\end{array}$ & $\begin{array}{l}\text { In front of } \\
\text { housing }\end{array}$ & $\begin{array}{l}\text { New tree. Unimproved semi- } \\
\text { detached home. }\end{array}$ \\
\hline $\begin{array}{l}\text { Kentucky } \\
\text { Coffeetree }\end{array}$ & $\begin{array}{l}\text { Gymnocladus } \\
\text { dioicus }\end{array}$ & good condition & 0 & $\begin{array}{l}43.658481^{\circ} \\
-79.449386^{\circ}\end{array}$ & $\begin{array}{l}\text { In front of } \\
\text { housing }\end{array}$ & $\begin{array}{l}\text { New tree. Improved semi- } \\
\text { detached home. }\end{array}$ \\
\hline $\begin{array}{l}\text { Kentucky } \\
\text { Coffeetree }\end{array}$ & $\begin{array}{l}\text { Gymnocladus } \\
\text { dioicus }\end{array}$ & good condition & 0 & $\begin{array}{l}43.659771^{\circ} \\
-79.448094^{\circ}\end{array}$ & $\begin{array}{l}\text { In front of } \\
\text { housing }\end{array}$ & $\begin{array}{l}\text { New tree. Improved semi- } \\
\text { detached home. }\end{array}$ \\
\hline $\begin{array}{l}\text { Kentucky } \\
\text { Coffeetree }\end{array}$ & $\begin{array}{l}\text { Gymnocladus } \\
\text { dioicus }\end{array}$ & good condition & 0 & $\begin{array}{l}43.661624^{\circ}, \\
-79.447345^{\circ}\end{array}$ & $\begin{array}{l}\text { In front of } \\
\text { housing }\end{array}$ & $\begin{array}{l}\text { New tree. Semi-detached } \\
\text { home. Renovation status } \\
\text { unclear. }\end{array}$ \\
\hline $\begin{array}{l}\text { Kentucky } \\
\text { Coffeetree }\end{array}$ & $\begin{array}{l}\text { Gymnocladus } \\
\text { dioicus }\end{array}$ & good condition & 0 & $\begin{array}{l}43.660705^{\circ} \\
-79.451762^{\circ}\end{array}$ & $\begin{array}{l}\text { In front of } \\
\text { housing }\end{array}$ & $\begin{array}{l}\text { New tree. Stacked } \\
\text { townhome. }\end{array}$ \\
\hline $\begin{array}{l}\text { Kentucky } \\
\text { Yellowwoo } \\
\text { d }\end{array}$ & $\begin{array}{l}\text { Cladrastis } \\
\text { kentukea }\end{array}$ & good condition & 0 & $\begin{array}{l}43.657532^{\circ} \\
-79.449014^{\circ}\end{array}$ & $\begin{array}{l}\text { In front of } \\
\text { housing }\end{array}$ & $\begin{array}{l}\text { New tree. Improved semi- } \\
\text { detached home. }\end{array}$ \\
\hline $\begin{array}{l}\text { Kentucky } \\
\text { Yellowwoo } \\
\text { d }\end{array}$ & $\begin{array}{l}\text { Cladrastis } \\
\text { kentukea }\end{array}$ & good condition & 0 & $\begin{array}{l}43.658070^{\circ} \\
-79.447188^{\circ}\end{array}$ & $\begin{array}{l}\text { In front of } \\
\text { housing }\end{array}$ & New tree. Row home. \\
\hline $\begin{array}{l}\text { Kentucky } \\
\text { Yelloww oo } \\
\text { d }\end{array}$ & $\begin{array}{l}\text { Cladrastis } \\
\text { kentukea }\end{array}$ & good condition & 0 & $\begin{array}{l}43.658079^{\circ} \\
-79.447146^{\circ}\end{array}$ & $\begin{array}{l}\text { In front of } \\
\text { housing }\end{array}$ & New tree. Row home. \\
\hline $\begin{array}{l}\text { Kentucky } \\
\text { Yellowwoo } \\
\text { d }\end{array}$ & $\begin{array}{l}\text { Cladrastis } \\
\text { kentukea }\end{array}$ & $50 \%$ dieback, tree lean & 3 & $\begin{array}{l}43.658113^{\circ} \\
-79.446999^{\circ}\end{array}$ & $\begin{array}{l}\text { In front of } \\
\text { housing }\end{array}$ & New tree. Row home. \\
\hline $\begin{array}{l}\text { Little Leaf } \\
\text { Linden }\end{array}$ & Tilia cordata & good condition & 0 & $\begin{array}{l}43.658594^{\circ} \\
-79.450506^{\circ}\end{array}$ & $\begin{array}{l}\text { In front of } \\
\text { housing }\end{array}$ & $\begin{array}{l}\text { New tree. Unimproved semi- } \\
\text { detached home. }\end{array}$ \\
\hline $\begin{array}{l}\text { Little Leaf } \\
\text { Linden }\end{array}$ & Tilia cordata & good condition & 0 & $\begin{array}{l}43.658588^{\circ}, \\
-79.450520^{\circ}\end{array}$ & $\begin{array}{l}\text { In front of } \\
\text { housing }\end{array}$ & $\begin{array}{l}\text { New tree. Improved semi- } \\
\text { detached home. }\end{array}$ \\
\hline $\begin{array}{l}\text { Little Leaf } \\
\text { Linden }\end{array}$ & Tilla cordata & tree lean & 1 & $\begin{array}{l}43.660975^{\circ} \\
-79.450393^{\circ}\end{array}$ & $\begin{array}{l}\text { In front of } \\
\text { housing }\end{array}$ & $\begin{array}{l}\text { New tree. Improved semi- } \\
\text { detached home. }\end{array}$ \\
\hline $\begin{array}{l}\text { Little Leaf } \\
\text { Linden }\end{array}$ & Tilla cordata & good condition & 0 & $\begin{array}{l}43.658030^{\circ} \\
-79.447373^{\circ}\end{array}$ & $\begin{array}{l}\text { In front of } \\
\text { housing }\end{array}$ & New tree. Row home. \\
\hline $\begin{array}{l}\text { Little Leaf } \\
\text { Linden }\end{array}$ & Tilla cordata & good condition & 0 & $\begin{array}{l}43.658041^{\circ}, \\
-79.447329^{\circ}\end{array}$ & $\begin{array}{l}\text { In front of } \\
\text { housing }\end{array}$ & New tree. Row home. \\
\hline $\begin{array}{l}\text { Little Leaf } \\
\text { Linden }\end{array}$ & Tilla cordata & good condition & 0 & $\begin{array}{l}43.658096^{\circ}, \\
-79.447050^{\circ}\end{array}$ & $\begin{array}{l}\text { In front of } \\
\text { housing }\end{array}$ & New tree. Row home. \\
\hline $\begin{array}{l}\text { Little Leaf } \\
\text { Linden }\end{array}$ & Tilla cordata & good condition & 0 & $\begin{array}{l}43.658115^{\circ}, \\
-79.446943^{\circ}\end{array}$ & $\begin{array}{l}\text { In front of } \\
\text { housing }\end{array}$ & New tree. Row home. \\
\hline $\begin{array}{l}\text { Little Leaf } \\
\text { Linden }\end{array}$ & Tilla cordata & good condition & 0 & $\begin{array}{l}43.658139^{\circ}, \\
-79.446837^{\circ}\end{array}$ & $\begin{array}{l}\text { In front of } \\
\text { housing }\end{array}$ & New tree. Row home. \\
\hline $\begin{array}{l}\text { Little Leaf } \\
\text { Linden }\end{array}$ & Tilla cordata & good condition & 0 & $\begin{array}{l}43.658152^{\circ}, \\
-79.446791^{\circ}\end{array}$ & $\begin{array}{l}\text { In front of } \\
\text { housing }\end{array}$ & New tree. Row home. \\
\hline $\begin{array}{l}\text { Little Leaf } \\
\text { Linden }\end{array}$ & Tilia cordata & cracks on trunk & 1 & $\begin{array}{l}43.660000^{\circ}, \\
-79.450880^{\circ}\end{array}$ & $\begin{array}{l}\text { In front of } \\
\text { housing }\end{array}$ & $\begin{array}{l}\text { New tree. Stacked } \\
\text { townhome. }\end{array}$ \\
\hline $\begin{array}{l}\text { Little Leaf } \\
\text { Linden }\end{array}$ & Tilia cordata & cracks on trunk & 1 & $\begin{array}{l}43.660052^{\circ}, \\
-79.450901^{\circ}\end{array}$ & $\begin{array}{l}\text { In front of } \\
\text { housing }\end{array}$ & $\begin{array}{l}\text { New tree. Stacked } \\
\text { townhome. }\end{array}$ \\
\hline $\begin{array}{l}\text { Little Leaf } \\
\text { Linden }\end{array}$ & Tilia cordata & good condition & 0 & $\begin{array}{l}43.660066^{\circ}, \\
-79.451205^{\circ} \\
\end{array}$ & $\begin{array}{l}\text { In front of } \\
\text { housing }\end{array}$ & $\begin{array}{l}\text { New tree. Stacked } \\
\text { townhome. }\end{array}$ \\
\hline $\begin{array}{l}\text { Little Leaf } \\
\text { Linden }\end{array}$ & Tilia cordata & cracks on trunk & 1 & $\begin{array}{l}43.660070^{\circ}, \\
-79.450860^{\circ}\end{array}$ & $\begin{array}{l}\text { In front of } \\
\text { housing }\end{array}$ & $\begin{array}{l}\text { New tree. Stacked } \\
\text { townhome. }\end{array}$ \\
\hline $\begin{array}{l}\text { Little Leaf } \\
\text { Linden }\end{array}$ & Tilla cordata & good condition & 0 & $\begin{array}{l}43.660071^{\circ}, \\
-79.451537^{\circ}\end{array}$ & $\begin{array}{l}\text { In front of } \\
\text { housing }\end{array}$ & $\begin{array}{l}\text { New tree. Stacked } \\
\text { townhome. }\end{array}$ \\
\hline $\begin{array}{l}\text { Little Leaf } \\
\text { Linden }\end{array}$ & Tilia cordata & cracks on trunk & 1 & $\begin{array}{l}43.660078^{\circ}, \\
-79.450909^{\circ}\end{array}$ & $\begin{array}{l}\text { In front of } \\
\text { housing }\end{array}$ & $\begin{array}{l}\text { New tree. Stacked } \\
\text { townhome. }\end{array}$ \\
\hline $\begin{array}{l}\text { Little Leaf } \\
\text { Linden }\end{array}$ & Tilia cordata & good condition & 0 & $\begin{array}{l}43.660129^{\circ}, \\
-79.450936^{\circ}\end{array}$ & $\begin{array}{l}\text { In front of } \\
\text { housing }\end{array}$ & $\begin{array}{l}\text { New tree. Stacked } \\
\text { townhome. }\end{array}$ \\
\hline $\begin{array}{l}\text { Little Leaf } \\
\text { Linden }\end{array}$ & Tilia cordata & good condition & 0 & $\begin{array}{l}43.660165^{\circ}, \\
-79.450960^{\circ}\end{array}$ & $\begin{array}{l}\text { In front of } \\
\text { housing }\end{array}$ & $\begin{array}{l}\text { New tree. Stacked } \\
\text { townhome. }\end{array}$ \\
\hline $\begin{array}{l}\text { Little Leaf } \\
\text { Linden }\end{array}$ & Tilia cordata & good condition & 0 & $\begin{array}{l}43.660186^{\circ}, \\
-79.451282^{\circ}\end{array}$ & $\begin{array}{l}\text { In front of } \\
\text { housing }\end{array}$ & $\begin{array}{l}\text { New tree. Stacked } \\
\text { townhome. }\end{array}$ \\
\hline $\begin{array}{l}\text { Little Leaf } \\
\text { Linden }\end{array}$ & Tilia cordata & good condition & 0 & $\begin{array}{l}43.660194^{\circ}, \\
-79.451098^{\circ}\end{array}$ & $\begin{array}{l}\text { In front of } \\
\text { housing }\end{array}$ & $\begin{array}{l}\text { New tree. Stacked } \\
\text { townhome. }\end{array}$ \\
\hline $\begin{array}{l}\text { Little Leaf } \\
\text { Linden }\end{array}$ & Tilia cordata & good condition & 0 & $\begin{array}{l}43.660196^{\circ}, \\
-79.451020^{\circ}\end{array}$ & $\begin{array}{l}\text { In front of } \\
\text { housing }\end{array}$ & $\begin{array}{l}\text { New tree. Stacked } \\
\text { townhome. }\end{array}$ \\
\hline
\end{tabular}




\begin{tabular}{|c|c|c|c|c|c|c|}
\hline $\begin{array}{l}\text { Little Leaf } \\
\text { Linden }\end{array}$ & Tilla cordata & good condition & 0 & $\begin{array}{l}43.660237^{\circ}, \\
-79.451610^{\circ}\end{array}$ & $\begin{array}{l}\text { In front of } \\
\text { housing }\end{array}$ & $\begin{array}{l}\text { New tree. Stacked } \\
\text { townhome. }\end{array}$ \\
\hline $\begin{array}{l}\text { Little Leaf } \\
\text { Linden }\end{array}$ & Tilla cordata & good condition & 0 & $\begin{array}{l}43.660305^{\circ}, \\
-79.451503^{\circ}\end{array}$ & $\begin{array}{l}\text { In front of } \\
\text { housing }\end{array}$ & $\begin{array}{l}\text { New tree. Stacked } \\
\text { townhome. }\end{array}$ \\
\hline $\begin{array}{l}\text { Little Leaf } \\
\text { Linden }\end{array}$ & Tilla cordata & cracks on trunk & 1 & $\begin{array}{l}43.660325^{\circ}, \\
-79.451439^{\circ}\end{array}$ & $\begin{array}{l}\text { In front of } \\
\text { housing }\end{array}$ & $\begin{array}{l}\text { New tree. Stacked } \\
\text { townhome. }\end{array}$ \\
\hline $\begin{array}{l}\text { Little Leaf } \\
\text { Linden }\end{array}$ & Tilla cordata & $\begin{array}{l}\text { cracks on trunk, weak } \\
\text { branch unions }\end{array}$ & 2 & $\begin{array}{l}43.660374^{\circ}, \\
-79.451174^{\circ}\end{array}$ & $\begin{array}{l}\text { In front of } \\
\text { housing }\end{array}$ & $\begin{array}{l}\text { New tree. Stacked } \\
\text { townhome. }\end{array}$ \\
\hline $\begin{array}{l}\text { Little Leaf } \\
\text { Linden }\end{array}$ & Tilla cordata & good condition & 0 & $\begin{array}{l}43.660389^{\circ}, \\
-79.451084^{\circ}\end{array}$ & $\begin{array}{l}\text { In front of } \\
\text { housing }\end{array}$ & $\begin{array}{l}\text { New tree. Stacked } \\
\text { townhome. }\end{array}$ \\
\hline $\begin{array}{l}\text { Little Leaf } \\
\text { Linden }\end{array}$ & Tilla cordata & good condition & 0 & $\begin{array}{l}43.660407^{\circ}, \\
-79.451009^{\circ}\end{array}$ & $\begin{array}{l}\text { In front of } \\
\text { housing }\end{array}$ & $\begin{array}{l}\text { New tree. Stacked } \\
\text { townhome. }\end{array}$ \\
\hline $\begin{array}{l}\text { Little Leaf } \\
\text { Linden }\end{array}$ & Tilla cordata & cracks on trunk & 1 & $\begin{array}{l}43.660591^{\circ}, \\
-79.451330^{\circ}\end{array}$ & $\begin{array}{l}\text { In front of } \\
\text { housing }\end{array}$ & $\begin{array}{l}\text { New tree. Stacked } \\
\text { townhome. }\end{array}$ \\
\hline $\begin{array}{l}\text { Little Leaf } \\
\text { Linden }\end{array}$ & Tilia cordata & cankers on trunk & 1 & $\begin{array}{l}43.660667^{\circ}, \\
-79.449008^{\circ}\end{array}$ & $\begin{array}{l}\text { In front of } \\
\text { housing }\end{array}$ & $\begin{array}{l}\text { Unimproved semi-detached } \\
\text { home. }\end{array}$ \\
\hline $\begin{array}{l}\text { Little Leaf } \\
\text { Linden }\end{array}$ & Tilia cordata & good condition & 0 & $\begin{array}{l}43.658640^{\circ}, \\
-79.450262^{\circ}\end{array}$ & $\begin{array}{l}\text { In front of } \\
\text { housing }\end{array}$ & $\begin{array}{l}\text { Improved semi-detached } \\
\text { home. }\end{array}$ \\
\hline $\begin{array}{l}\text { Little Leaf } \\
\text { Linden }\end{array}$ & Tilia cordata & good condition & 0 & $\begin{array}{l}43.660091^{\circ}, \\
-79.447958^{\circ}\end{array}$ & $\begin{array}{l}\text { In front of } \\
\text { housing }\end{array}$ & $\begin{array}{l}\text { Improved semi-detached } \\
\text { home. }\end{array}$ \\
\hline $\begin{array}{l}\text { Little Leaf } \\
\text { Linden }\end{array}$ & Tilla cordata & good condition & 0 & $\begin{array}{l}43.660774^{\circ}, \\
-79.449264^{\circ}\end{array}$ & $\begin{array}{l}\text { In front of } \\
\text { housing }\end{array}$ & $\begin{array}{l}\text { Improved semi-detached } \\
\text { home. }\end{array}$ \\
\hline $\begin{array}{l}\text { Little Leaf } \\
\text { Linden }\end{array}$ & Tilla cordata & good condition & 0 & $\begin{array}{l}43.658126^{\circ}, \\
-79.447892^{\circ}\end{array}$ & $\begin{array}{l}\text { In front of } \\
\text { housing }\end{array}$ & Row home. \\
\hline $\begin{array}{l}\text { Little Leaf } \\
\text { Linden }\end{array}$ & Tilla cordata & good condition & 0 & $\begin{array}{l}43.658128^{\circ} \\
-79.447873^{\circ}\end{array}$ & $\begin{array}{l}\text { In front of } \\
\text { housing }\end{array}$ & Row home. \\
\hline $\begin{array}{l}\text { Little Leaf } \\
\text { Linden }\end{array}$ & Tilla cordata & defoliation & 1 & $\begin{array}{l}43.660503^{\circ}, \\
-79.451584^{\circ}\end{array}$ & $\begin{array}{l}\text { In front of } \\
\text { housing }\end{array}$ & Stacked townhome. \\
\hline $\begin{array}{l}\text { Little Leaf } \\
\text { Linden }\end{array}$ & Tilla cordata & defoliation & 1 & $\begin{array}{l}43.660514^{\circ}, \\
-79.451502^{\circ}\end{array}$ & $\begin{array}{l}\text { In front of } \\
\text { housing }\end{array}$ & Stacked townhome. \\
\hline $\begin{array}{l}\text { Little Leaf } \\
\text { Linden }\end{array}$ & Tilla cordata & defoliation & 1 & $\begin{array}{l}43.660547^{\circ}, \\
-79.451512^{\circ}\end{array}$ & $\begin{array}{l}\text { In front of } \\
\text { housing }\end{array}$ & Stacked townhome. \\
\hline $\begin{array}{l}\text { London } \\
\text { Plane Tree }\end{array}$ & $\begin{array}{l}\text { Platanus } \times \\
\text { acerifolia }\end{array}$ & good condition & 0 & $\begin{array}{l}43.658832^{\circ}, \\
-79.448481^{\circ}\end{array}$ & $\begin{array}{l}\text { In front of } \\
\text { housing }\end{array}$ & $\begin{array}{l}\text { New tree. Improved semi- } \\
\text { detached home. }\end{array}$ \\
\hline $\begin{array}{l}\text { London } \\
\text { Plane Tree }\end{array}$ & $\begin{array}{l}\text { Platanus } \times \\
\text { acerifolia }\end{array}$ & good condition & 0 & $\begin{array}{l}43.660909^{\circ}, \\
-79.449223^{\circ}\end{array}$ & $\begin{array}{l}\text { In front of } \\
\text { housing }\end{array}$ & $\begin{array}{l}\text { New tree. Improved semi- } \\
\text { detached home. }\end{array}$ \\
\hline $\begin{array}{l}\text { London } \\
\text { Plane Tree }\end{array}$ & $\begin{array}{l}\text { Platanus } \times \\
\text { acerifolia }\end{array}$ & good condition & 0 & $\begin{array}{l}43.660992^{\circ}, \\
-79.448302^{\circ}\end{array}$ & $\begin{array}{l}\text { In front of } \\
\text { housing }\end{array}$ & $\begin{array}{l}\text { New tree. Improved semi- } \\
\text { detached home. }\end{array}$ \\
\hline $\begin{array}{l}\text { London } \\
\text { Plane Tree }\end{array}$ & $\begin{array}{l}\text { Platanus } \times \\
\text { acerifolia }\end{array}$ & $\begin{array}{l}50 \% \text { dieback, weak branch } \\
\text { unions }\end{array}$ & 3 & $\begin{array}{l}43.657896^{\circ}, \\
-79.447811^{\circ}\end{array}$ & $\begin{array}{l}\text { In front of } \\
\text { housing }\end{array}$ & New tree. Row home. \\
\hline $\begin{array}{l}\text { London } \\
\text { Plane Tree }\end{array}$ & $\begin{array}{l}\text { Platanus } \times \\
\text { acerifolia }\end{array}$ & $20 \%$ dieback & 1 & $\begin{array}{l}43.657923^{\circ}, \\
-79.447868^{\circ}\end{array}$ & $\begin{array}{l}\text { In front of } \\
\text { housing }\end{array}$ & New tree. Row home. \\
\hline $\begin{array}{l}\text { London } \\
\text { Plane Tree }\end{array}$ & $\begin{array}{l}\text { Platanus } \times \\
\text { acerifolia }\end{array}$ & broken branches & 1 & $\begin{array}{l}43.657985^{\circ}, \\
-79.447904^{\circ}\end{array}$ & $\begin{array}{l}\text { In front of } \\
\text { housing }\end{array}$ & New tree. Row home. \\
\hline $\begin{array}{l}\text { London } \\
\text { Plane Tree }\end{array}$ & $\begin{array}{l}\text { Platanus } \times \\
\text { acerifolia }\end{array}$ & $20 \%$ dieback & 2 & $\begin{array}{l}43.658019^{\circ}, \\
-79.447920^{\circ}\end{array}$ & $\begin{array}{l}\text { In front of } \\
\text { housing }\end{array}$ & New tree. Row home. \\
\hline $\begin{array}{l}\text { London } \\
\text { Plane Tree }\end{array}$ & $\begin{array}{l}\text { Platanus } \times \\
\text { acerifolia }\end{array}$ & $\begin{array}{l}\text { cracks on bark, } 20 \% \\
\text { dieback }\end{array}$ & 3 & $\begin{array}{l}43.658039^{\circ}, \\
-79.447918^{\circ}\end{array}$ & $\begin{array}{l}\text { In front of } \\
\text { housing }\end{array}$ & New tree. Row home. \\
\hline $\begin{array}{l}\text { Manitoba } \\
\text { Maple }\end{array}$ & Acer negundo & cracks on trunk & 1 & $\begin{array}{l}43.659390^{\circ}, \\
-79.449986^{\circ}\end{array}$ & $\begin{array}{l}\text { In front of } \\
\text { housing }\end{array}$ & Business. \\
\hline $\begin{array}{l}\text { Manitoba } \\
\text { Maple }\end{array}$ & Acer negundo & $10 \%$ dieback & 1 & $\begin{array}{l}43.657044^{\circ}, \\
-79.449538^{\circ}\end{array}$ & $\begin{array}{l}\text { In front of } \\
\text { housing }\end{array}$ & Low-rise apartment. \\
\hline $\begin{array}{l}\text { Manitoba } \\
\text { Maple }\end{array}$ & Acer negundo & $10 \%$ dieback & 1 & $\begin{array}{l}43.657149^{\circ}, \\
-79.449118^{\circ}\end{array}$ & $\begin{array}{l}\text { In front of } \\
\text { housing }\end{array}$ & Low-rise apartment. \\
\hline $\begin{array}{l}\text { Manitoba } \\
\text { Maple }\end{array}$ & Acer negundo & tree lean, peeling bark & 2 & $\begin{array}{l}43.657175^{\circ}, \\
-79.449165^{\circ}\end{array}$ & $\begin{array}{l}\text { In front of } \\
\text { housing }\end{array}$ & Low-rise apartment. \\
\hline $\begin{array}{l}\text { Manitoba } \\
\text { Maple }\end{array}$ & Acer negundo & good condition & 0 & $\begin{array}{l}43.657607^{\circ}, \\
-79.449962^{\circ}\end{array}$ & $\begin{array}{l}\text { In front of } \\
\text { housing }\end{array}$ & Low-rise apartment. \\
\hline $\begin{array}{l}\text { Manitoba } \\
\text { Maple }\end{array}$ & Acer negundo & tree lean, peeling bark & 2 & $\begin{array}{l}43.657645^{\circ}, \\
-79.449252^{\circ}\end{array}$ & $\begin{array}{l}\text { In front of } \\
\text { housing }\end{array}$ & Low-rise apartment. \\
\hline $\begin{array}{l}\text { Manitoba } \\
\text { Maple }\end{array}$ & Acer negundo & good condition & 0 & $\begin{array}{l}43.657660^{\circ}, \\
-79.449721^{\circ}\end{array}$ & $\begin{array}{l}\text { In front of } \\
\text { housing }\end{array}$ & Low-rise apartment. \\
\hline $\begin{array}{l}\text { Manitoba } \\
\text { Maple }\end{array}$ & Acer negundo & tree lean & 1 & $\begin{array}{l}43.657704^{\circ}, \\
-79.449581^{\circ}\end{array}$ & $\begin{array}{l}\text { In front of } \\
\text { housing }\end{array}$ & Low-rise apartment. \\
\hline $\begin{array}{l}\text { Manitoba } \\
\text { Maple }\end{array}$ & Acer negundo & tree lean & 1 & $\begin{array}{l}43.657731^{\circ}, \\
-79.449432^{\circ}\end{array}$ & $\begin{array}{l}\text { In front of } \\
\text { housing }\end{array}$ & Low-rise apartment. \\
\hline $\begin{array}{l}\text { Manitoba } \\
\text { Maple }\end{array}$ & Acer negundo & dead branches & 1 & $\begin{array}{l}43.657743^{\circ}, \\
-79.449344^{\circ}\end{array}$ & $\begin{array}{l}\text { In front of } \\
\text { housing }\end{array}$ & Low-rise apartment. \\
\hline
\end{tabular}




\begin{tabular}{|c|c|c|c|c|c|c|}
\hline $\begin{array}{l}\text { Manitoba } \\
\text { Maple }\end{array}$ & Acer negundo & tree lean, defoliation & 2 & $\begin{array}{l}43.657914^{\circ}, \\
-79.446518^{\circ}\end{array}$ & $\begin{array}{l}\text { In front of } \\
\text { housing }\end{array}$ & Low-rise apartment. \\
\hline $\begin{array}{l}\text { Manitoba } \\
\text { Maple }\end{array}$ & Acer negundo & tree lean & 1 & $\begin{array}{l}43.661136^{\circ}, \\
-79.447349^{\circ}\end{array}$ & $\begin{array}{l}\text { In front of } \\
\text { housing }\end{array}$ & $\begin{array}{l}\text { New tree. Semi-detached } \\
\text { home. Renovation status } \\
\text { unclear. }\end{array}$ \\
\hline $\begin{array}{l}\text { Manitoba } \\
\text { Maple }\end{array}$ & Acer negundo & tree lean, defoliation & 2 & $\begin{array}{l}43.660820^{\circ}, \\
-79.449074^{\circ}\end{array}$ & $\begin{array}{l}\text { In front of } \\
\text { housing }\end{array}$ & $\begin{array}{l}\text { Unimproved semi-detached } \\
\text { home. }\end{array}$ \\
\hline $\begin{array}{l}\text { Manitoba } \\
\text { Maple }\end{array}$ & Acer negundo & tree lean & 1 & $\begin{array}{l}43.660315^{\circ}, \\
-79.448012^{\circ}\end{array}$ & $\begin{array}{l}\text { In front of } \\
\text { housing }\end{array}$ & $\begin{array}{l}\text { Improved semi-detached } \\
\text { home. }\end{array}$ \\
\hline $\begin{array}{l}\text { Manitoba } \\
\text { Maple }\end{array}$ & Acer negundo & tree lean, $10 \%$ dieback & 2 & $\begin{array}{l}43.660742^{\circ}, \\
-79.448245^{\circ}\end{array}$ & $\begin{array}{l}\text { In front of } \\
\text { housing }\end{array}$ & $\begin{array}{l}\text { Improved semi-detached } \\
\text { home. }\end{array}$ \\
\hline $\begin{array}{l}\text { Manitoba } \\
\text { Maple }\end{array}$ & Acer negundo & tree lean & 1 & $\begin{array}{l}43.658861^{\circ}, \\
-79.446403^{\circ}\end{array}$ & $\begin{array}{l}\text { In front of } \\
\text { housing }\end{array}$ & $\begin{array}{l}\text { Semi-detached home. } \\
\text { Renovation status unclear. }\end{array}$ \\
\hline $\begin{array}{l}\text { Northern } \\
\text { Catalpa }\end{array}$ & $\begin{array}{l}\text { Catalpa } \\
\text { speciosa }\end{array}$ & good condition & 0 & $\begin{array}{l}43.660823^{\circ}, \\
-79.449289^{\circ}\end{array}$ & $\begin{array}{l}\text { In front of } \\
\text { housing }\end{array}$ & $\begin{array}{l}\text { New tree. Improved semi- } \\
\text { detached home. }\end{array}$ \\
\hline $\begin{array}{l}\text { Norway } \\
\text { Maple }\end{array}$ & $\begin{array}{l}\text { Acer } \\
\text { platanoides }\end{array}$ & dead branches, tree Lean & 2 & $\begin{array}{l}43.657057^{\circ}, \\
-79.449469^{\circ}\end{array}$ & $\begin{array}{l}\text { In front of } \\
\text { housing }\end{array}$ & Low-rise apartment. \\
\hline $\begin{array}{l}\text { Norway } \\
\text { Maple }\end{array}$ & $\begin{array}{l}\text { Acer } \\
\text { platanoides }\end{array}$ & dead branches, tree Lean & 2 & $\begin{array}{l}43.657072^{\circ}, \\
-79.449402^{\circ}\end{array}$ & $\begin{array}{l}\text { In front of } \\
\text { housing }\end{array}$ & Low-rise apartment. \\
\hline $\begin{array}{l}\text { Norway } \\
\text { Maple }\end{array}$ & $\begin{array}{l}\text { Acer } \\
\text { platanoides }\end{array}$ & tree lean & 1 & $\begin{array}{l}43.657087^{\circ}, \\
-79.449316^{\circ}\end{array}$ & $\begin{array}{l}\text { In front of } \\
\text { housing }\end{array}$ & Low-rise apartment. \\
\hline $\begin{array}{l}\text { Norway } \\
\text { Maple }\end{array}$ & $\begin{array}{l}\text { Acer } \\
\text { platanoides }\end{array}$ & tree lean & 1 & $\begin{array}{l}43.657109^{\circ}, \\
-79.449233^{\circ}\end{array}$ & $\begin{array}{l}\text { In front of } \\
\text { housing }\end{array}$ & Low-rise apartment. \\
\hline $\begin{array}{l}\text { Norway } \\
\text { Maple }\end{array}$ & $\begin{array}{l}\text { Acer } \\
\text { platanoides }\end{array}$ & tree Lean & 1 & $\begin{array}{l}43.657218^{\circ}, \\
-79.449130^{\circ}\end{array}$ & $\begin{array}{l}\text { In front of } \\
\text { housing }\end{array}$ & Low-rise apartment. \\
\hline $\begin{array}{l}\text { Norway } \\
\text { Maple }\end{array}$ & $\begin{array}{l}\text { Acer } \\
\text { platanoides }\end{array}$ & tree lean & 1 & $\begin{array}{l}43.657251^{\circ}, \\
-79.449174^{\circ}\end{array}$ & $\begin{array}{l}\text { In front of } \\
\text { housing }\end{array}$ & Low-rise apartment. \\
\hline $\begin{array}{l}\text { Norway } \\
\text { Maple }\end{array}$ & $\begin{array}{l}\text { Acer } \\
\text { platanoides }\end{array}$ & dead branches, tree Lean & 2 & $\begin{array}{l}43.657253^{\circ}, \\
-79.449352^{\circ}\end{array}$ & $\begin{array}{l}\text { In front of } \\
\text { housing }\end{array}$ & Low-rise apartment. \\
\hline $\begin{array}{l}\text { Norway } \\
\text { Maple }\end{array}$ & $\begin{array}{l}\text { Acer } \\
\text { platanoides }\end{array}$ & good condition & 0 & $\begin{array}{l}43.657451^{\circ}, \\
-79.449181^{\circ}\end{array}$ & $\begin{array}{l}\text { In front of } \\
\text { housing }\end{array}$ & Low-rise apartment. \\
\hline $\begin{array}{l}\text { Norway } \\
\text { Maple }\end{array}$ & $\begin{array}{l}\text { Acer } \\
\text { platanoides }\end{array}$ & good condition & 0 & $\begin{array}{l}43.657530^{\circ}, \\
-79.449171^{\circ} \\
\end{array}$ & $\begin{array}{l}\text { In front of } \\
\text { housing }\end{array}$ & Low-rise apartment. \\
\hline $\begin{array}{l}\text { Norway } \\
\text { Maple }\end{array}$ & $\begin{array}{l}\text { Acer } \\
\text { platanoides }\end{array}$ & good condition & 0 & $\begin{array}{l}43.657572^{\circ}, \\
-79.449205^{\circ}\end{array}$ & $\begin{array}{l}\text { In front of } \\
\text { housing }\end{array}$ & Low-rise apartment. \\
\hline $\begin{array}{l}\text { Norway } \\
\text { Maple }\end{array}$ & $\begin{array}{l}\text { Acer } \\
\text { platanoides }\end{array}$ & cankers on trunk & 1 & $\begin{array}{l}43.659393^{\circ}, \\
-79.449762^{\circ}\end{array}$ & $\begin{array}{l}\text { In front of } \\
\text { housing }\end{array}$ & $\begin{array}{l}\text { New tree. Unimproved semi- } \\
\text { detached home. }\end{array}$ \\
\hline $\begin{array}{l}\text { Norway } \\
\text { Maple }\end{array}$ & $\begin{array}{l}\text { Acer } \\
\text { platanoides }\end{array}$ & tree lean & 1 & $\begin{array}{l}43.659488^{\circ}, \\
-79.449715^{\circ}\end{array}$ & $\begin{array}{l}\text { In front of } \\
\text { housing }\end{array}$ & $\begin{array}{l}\text { New tree. Unimproved semi- } \\
\text { detached home. }\end{array}$ \\
\hline $\begin{array}{l}\text { Norway } \\
\text { Maple }\end{array}$ & $\begin{array}{l}\text { Acer } \\
\text { platanoides }\end{array}$ & tree lean & 1 & $\begin{array}{l}43.660840^{\circ}, \\
-79.448038^{\circ}\end{array}$ & $\begin{array}{l}\text { In front of } \\
\text { housing }\end{array}$ & $\begin{array}{l}\text { New tree. Unimproved semi- } \\
\text { detached home. }\end{array}$ \\
\hline $\begin{array}{l}\text { Norway } \\
\text { Maple }\end{array}$ & $\begin{array}{l}\text { Acer } \\
\text { platanoides }\end{array}$ & good condition & 0 & $\begin{array}{l}43.659967^{\circ} \\
-79.447131^{\circ}\end{array}$ & $\begin{array}{l}\text { In front of } \\
\text { housing }\end{array}$ & $\begin{array}{l}\text { New tree. Semi-detached } \\
\text { home. Renovation status } \\
\text { unclear. }\end{array}$ \\
\hline $\begin{array}{l}\text { Norway } \\
\text { Maple }\end{array}$ & $\begin{array}{l}\text { Acer } \\
\text { platanoides }\end{array}$ & good condition & 0 & $\begin{array}{l}43.660003^{\circ}, \\
-79.446970^{\circ}\end{array}$ & $\begin{array}{l}\text { In front of } \\
\text { housing }\end{array}$ & $\begin{array}{l}\text { New tree. Semi-detached } \\
\text { home. Renovation status } \\
\text { unclear. }\end{array}$ \\
\hline $\begin{array}{l}\text { Norway } \\
\text { Maple }\end{array}$ & $\begin{array}{l}\text { Acer } \\
\text { platanoides }\end{array}$ & good condition & 0 & $\begin{array}{l}43.660072^{\circ}, \\
-79.446653^{\circ}\end{array}$ & $\begin{array}{l}\text { In front of } \\
\text { housing }\end{array}$ & $\begin{array}{l}\text { New tree. Semi-detached } \\
\text { home. Renovation status } \\
\text { unclear. }\end{array}$ \\
\hline $\begin{array}{l}\text { Norway } \\
\text { Maple }\end{array}$ & $\begin{array}{l}\text { Acer } \\
\text { platanoides }\end{array}$ & good condition & 0 & $\begin{array}{l}43.660094^{\circ}, \\
-79.446904^{\circ}\end{array}$ & $\begin{array}{l}\text { In front of } \\
\text { housing }\end{array}$ & $\begin{array}{l}\text { New tree. Semi-detached } \\
\text { home. Renovation status } \\
\text { unclear. }\end{array}$ \\
\hline $\begin{array}{l}\text { Norway } \\
\text { Maple }\end{array}$ & $\begin{array}{l}\text { Acer } \\
\text { platanoides }\end{array}$ & good condition & 0 & $\begin{array}{l}43.660117^{\circ}, \\
-79.446405^{\circ}\end{array}$ & $\begin{array}{l}\text { In front of } \\
\text { housing }\end{array}$ & $\begin{array}{l}\text { New tree. Semi-detached } \\
\text { home. Renovation status } \\
\text { unclear. }\end{array}$ \\
\hline $\begin{array}{l}\text { Norway } \\
\text { Maple }\end{array}$ & $\begin{array}{l}\text { Acer } \\
\text { platanoides }\end{array}$ & good condition & 0 & $\begin{array}{l}43.660171^{\circ}, \\
-79.446939^{\circ}\end{array}$ & $\begin{array}{l}\text { In front of } \\
\text { housing }\end{array}$ & $\begin{array}{l}\text { New tree. Semi-detached } \\
\text { home. Renovation status } \\
\text { unclear. }\end{array}$ \\
\hline $\begin{array}{l}\text { Norway } \\
\text { Maple }\end{array}$ & $\begin{array}{l}\text { Acer } \\
\text { platanoides }\end{array}$ & good condition & 0 & $\begin{array}{l}43.660259^{\circ}, \\
-79.446982^{\circ}\end{array}$ & $\begin{array}{l}\text { In front of } \\
\text { housing }\end{array}$ & $\begin{array}{l}\text { New tree. Semi-detached } \\
\text { home. Renovation status } \\
\text { unclear. }\end{array}$ \\
\hline $\begin{array}{l}\text { Norway } \\
\text { Maple }\end{array}$ & $\begin{array}{l}\text { Acer } \\
\text { platanoides }\end{array}$ & good condition & 0 & $\begin{array}{l}43.660350^{\circ}, \\
-79.447020^{\circ}\end{array}$ & $\begin{array}{l}\text { In front of } \\
\text { housing }\end{array}$ & $\begin{array}{l}\text { New tree. Semi-detached } \\
\text { home. Renovation status } \\
\text { unclear. }\end{array}$ \\
\hline $\begin{array}{l}\text { Norway } \\
\text { Maple }\end{array}$ & $\begin{array}{l}\text { Acer } \\
\text { platanoides }\end{array}$ & good condition & 0 & $\begin{array}{l}43.660443^{\circ}, \\
-79.447054^{\circ}\end{array}$ & $\begin{array}{l}\text { In front of } \\
\text { housing }\end{array}$ & $\begin{array}{l}\text { New tree. Semi-detached } \\
\text { home. Renovation status } \\
\text { unclear. }\end{array}$ \\
\hline
\end{tabular}




\begin{tabular}{|c|c|c|c|c|c|c|}
\hline $\begin{array}{l}\text { Norway } \\
\text { Maple }\end{array}$ & $\begin{array}{l}\text { Acer } \\
\text { platanoides }\end{array}$ & good condition & 0 & $\begin{array}{l}43.657797^{\circ}, \\
-79.449119^{\circ}\end{array}$ & $\begin{array}{l}\text { In front of } \\
\text { housing }\end{array}$ & $\begin{array}{l}\text { Unimproved semi-detached } \\
\text { home. }\end{array}$ \\
\hline $\begin{array}{l}\text { Norway } \\
\text { Maple }\end{array}$ & $\begin{array}{l}\text { Acer } \\
\text { platanoides }\end{array}$ & tree lean & 1 & $\begin{array}{l}43.658604^{\circ}, \\
-79.450372^{\circ}\end{array}$ & $\begin{array}{l}\text { In front of } \\
\text { housing }\end{array}$ & $\begin{array}{l}\text { Unimproved semi-detached } \\
\text { home. }\end{array}$ \\
\hline $\begin{array}{l}\text { Norway } \\
\text { Maple }\end{array}$ & $\begin{array}{l}\text { Acer } \\
\text { platanoides }\end{array}$ & $\begin{array}{l}\text { tree lean, small cracks } \\
\text { along trunk }\end{array}$ & 2 & $\begin{array}{l}43.658761^{\circ}, \\
-79.449512^{\circ}\end{array}$ & $\begin{array}{l}\text { In front of } \\
\text { housing }\end{array}$ & $\begin{array}{l}\text { Unimproved semi-detached } \\
\text { home. }\end{array}$ \\
\hline $\begin{array}{l}\text { Norway } \\
\text { Maple }\end{array}$ & $\begin{array}{l}\text { Acer } \\
\text { platanoides }\end{array}$ & cracks and cankers on trunk & 1 & $\begin{array}{l}43.658834^{\circ}, \\
-79.447414^{\circ}\end{array}$ & $\begin{array}{l}\text { In front of } \\
\text { housing }\end{array}$ & $\begin{array}{l}\text { Unimproved semi-detached } \\
\text { home. }\end{array}$ \\
\hline $\begin{array}{l}\text { Norway } \\
\text { Maple }\end{array}$ & $\begin{array}{l}\text { Acer } \\
\text { platanoides }\end{array}$ & good condition & 0 & $\begin{array}{l}43.659040^{\circ} \\
-79.447495^{\circ}\end{array}$ & $\begin{array}{l}\text { In front of } \\
\text { housing }\end{array}$ & $\begin{array}{l}\text { Unimproved semi-detached } \\
\text { home. }\end{array}$ \\
\hline $\begin{array}{l}\text { Norway } \\
\text { Maple }\end{array}$ & $\begin{array}{l}\text { Acer } \\
\text { platanoides }\end{array}$ & tree lean & 1 & $\begin{array}{l}43.659813^{\circ} \\
-79.447868^{\circ}\end{array}$ & $\begin{array}{l}\text { In front of } \\
\text { housing }\end{array}$ & $\begin{array}{l}\text { Unimproved semi-detached } \\
\text { home. }\end{array}$ \\
\hline $\begin{array}{l}\text { Norway } \\
\text { Maple }\end{array}$ & $\begin{array}{l}\text { Acer } \\
\text { platanoides }\end{array}$ & cracks on trunk & 1 & $\begin{array}{l}43.660728^{\circ}, \\
-79.448018^{\circ}\end{array}$ & $\begin{array}{l}\text { In front of } \\
\text { housing }\end{array}$ & $\begin{array}{l}\text { Unimproved semi-detached } \\
\text { home. }\end{array}$ \\
\hline $\begin{array}{l}\text { Norway } \\
\text { Maple }\end{array}$ & $\begin{array}{l}\text { Acer } \\
\text { platanoides }\end{array}$ & tree lean, broken branches & 2 & $\begin{array}{l}43.660772^{\circ}, \\
-79.448027^{\circ}\end{array}$ & $\begin{array}{l}\text { In front of } \\
\text { housing }\end{array}$ & $\begin{array}{l}\text { Unimproved semi-detached } \\
\text { home. }\end{array}$ \\
\hline $\begin{array}{l}\text { Norway } \\
\text { Maple }\end{array}$ & $\begin{array}{l}\text { Acer } \\
\text { platanoides }\end{array}$ & tree lean & 1 & $\begin{array}{l}43.660993^{\circ}, \\
-79.449340^{\circ} \\
\end{array}$ & $\begin{array}{l}\text { In front of } \\
\text { housing }\end{array}$ & $\begin{array}{l}\text { Unimproved semi-detached } \\
\text { home. }\end{array}$ \\
\hline $\begin{array}{l}\text { Norway } \\
\text { Maple }\end{array}$ & $\begin{array}{l}\text { Acer } \\
\text { platanoides }\end{array}$ & cracks/cankers on trunk & 1 & $\begin{array}{l}43.661228^{\circ}, \\
-79.448050^{\circ}\end{array}$ & $\begin{array}{l}\text { In front of } \\
\text { housing }\end{array}$ & $\begin{array}{l}\text { Unimproved semi-detached } \\
\text { home. }\end{array}$ \\
\hline $\begin{array}{l}\text { Norway } \\
\text { Maple }\end{array}$ & $\begin{array}{l}\text { Acer } \\
\text { platanoides }\end{array}$ & cankers on trunk & 1 & $\begin{array}{l}43.659816^{\circ}, \\
-79.448864^{\circ}\end{array}$ & $\begin{array}{l}\text { In front of } \\
\text { housing }\end{array}$ & $\begin{array}{l}\text { Unimproved semi-detached } \\
\text { home. Near construction. }\end{array}$ \\
\hline $\begin{array}{l}\text { Norway } \\
\text { Maple }\end{array}$ & $\begin{array}{l}\text { Acer } \\
\text { platanoides }\end{array}$ & cracks and cankers on trunk & 2 & $\begin{array}{l}43.657619^{\circ}, \\
-79.449011^{\circ}\end{array}$ & $\begin{array}{l}\text { In front of } \\
\text { housing }\end{array}$ & $\begin{array}{l}\text { Improved semi-detached } \\
\text { home. }\end{array}$ \\
\hline $\begin{array}{l}\text { Norway } \\
\text { Maple }\end{array}$ & $\begin{array}{l}\text { Acer } \\
\text { platanoides }\end{array}$ & good condition & 0 & $\begin{array}{l}43.657851^{\circ}, \\
-79.449159^{\circ}\end{array}$ & $\begin{array}{l}\text { In front of } \\
\text { housing }\end{array}$ & $\begin{array}{l}\text { Improved semi-detached } \\
\text { home. }\end{array}$ \\
\hline $\begin{array}{l}\text { Norway } \\
\text { Maple }\end{array}$ & $\begin{array}{l}\text { Acer } \\
\text { platanoides }\end{array}$ & good condition & 1 & $\begin{array}{l}43.658068^{\circ}, \\
-79.449223^{\circ}\end{array}$ & $\begin{array}{l}\text { In front of } \\
\text { housing }\end{array}$ & $\begin{array}{l}\text { Improved semi-detached } \\
\text { home. }\end{array}$ \\
\hline $\begin{array}{l}\text { Norway } \\
\text { Maple }\end{array}$ & $\begin{array}{l}\text { Acer } \\
\text { platanoides }\end{array}$ & cankers on trunk, tree lean & 2 & $\begin{array}{l}43.658404^{\circ}, \\
-79.448301^{\circ} \\
\end{array}$ & $\begin{array}{l}\text { In front of } \\
\text { housing }\end{array}$ & $\begin{array}{l}\text { Improved semi-detached } \\
\text { home. }\end{array}$ \\
\hline $\begin{array}{l}\text { Norway } \\
\text { Maple }\end{array}$ & $\begin{array}{l}\text { Acer } \\
\text { platanoides }\end{array}$ & weak branch unions & 1 & $\begin{array}{l}43.659507^{\circ}, \\
-79.448734^{\circ}\end{array}$ & $\begin{array}{l}\text { In front of } \\
\text { housing }\end{array}$ & $\begin{array}{l}\text { Improved semi-detached } \\
\text { home. }\end{array}$ \\
\hline $\begin{array}{l}\text { Norway } \\
\text { Maple }\end{array}$ & $\begin{array}{l}\text { Acer } \\
\text { platanoides }\end{array}$ & cankers on trunk & 1 & $\begin{array}{l}43.659574^{\circ}, \\
-79.449363^{\circ}\end{array}$ & $\begin{array}{l}\text { In front of } \\
\text { housing }\end{array}$ & $\begin{array}{l}\text { Improved semi-detached } \\
\text { home. }\end{array}$ \\
\hline $\begin{array}{l}\text { Norway } \\
\text { Maple }\end{array}$ & $\begin{array}{l}\text { Acer } \\
\text { platanoides }\end{array}$ & $\begin{array}{l}\text { tree lean, cracks and } \\
\text { cankers on trunk }\end{array}$ & 3 & $\begin{array}{l}43.659642^{\circ}, \\
-79.447967^{\circ}\end{array}$ & $\begin{array}{l}\text { In front of } \\
\text { housing }\end{array}$ & $\begin{array}{l}\text { Improved semi-detached } \\
\text { home. }\end{array}$ \\
\hline $\begin{array}{l}\text { Norway } \\
\text { Maple }\end{array}$ & $\begin{array}{l}\text { Acer } \\
\text { platanoides }\end{array}$ & good condition & 0 & $\begin{array}{l}43.659650^{\circ}, \\
-79.447961^{\circ}\end{array}$ & $\begin{array}{l}\text { In front of } \\
\text { housing }\end{array}$ & $\begin{array}{l}\text { Improved semi-detached } \\
\text { home. }\end{array}$ \\
\hline $\begin{array}{l}\text { Norway } \\
\text { Maple }\end{array}$ & $\begin{array}{l}\text { Acer } \\
\text { platanoides }\end{array}$ & good condition & 0 & $\begin{array}{l}43.659678^{\circ}, \\
-79.447850^{\circ}\end{array}$ & $\begin{array}{l}\text { In front of } \\
\text { housing }\end{array}$ & $\begin{array}{l}\text { Improved semi-detached } \\
\text { home. }\end{array}$ \\
\hline $\begin{array}{l}\text { Norway } \\
\text { Maple }\end{array}$ & $\begin{array}{l}\text { Acer } \\
\text { platanoides }\end{array}$ & cracks on trunk & 1 & $\begin{array}{l}43.659719^{\circ}, \\
-79.450079^{\circ} \\
\end{array}$ & $\begin{array}{l}\text { In front of } \\
\text { housing }\end{array}$ & $\begin{array}{l}\text { Improved semi-detached } \\
\text { home. }\end{array}$ \\
\hline $\begin{array}{l}\text { Norway } \\
\text { Maple }\end{array}$ & $\begin{array}{l}\text { Acer } \\
\text { platanoides }\end{array}$ & good condition & 0 & $\begin{array}{l}43.659881^{\circ}, \\
-79.447489^{\circ}\end{array}$ & $\begin{array}{l}\text { In front of } \\
\text { housing }\end{array}$ & $\begin{array}{l}\text { Improved semi-detached } \\
\text { home. }\end{array}$ \\
\hline $\begin{array}{l}\text { Norway } \\
\text { Maple }\end{array}$ & $\begin{array}{l}\text { Acer } \\
\text { platanoides }\end{array}$ & tree lean & 1 & $\begin{array}{l}43.659902^{\circ}, \\
-79.448680^{\circ}\end{array}$ & $\begin{array}{l}\text { In front of } \\
\text { housing }\end{array}$ & $\begin{array}{l}\text { Improved semi-detached } \\
\text { home. }\end{array}$ \\
\hline $\begin{array}{l}\text { Norway } \\
\text { Maple }\end{array}$ & $\begin{array}{l}\text { Acer } \\
\text { platanoides }\end{array}$ & cracks on trunk & 1 & $\begin{array}{l}43.659993^{\circ}, \\
-79.450159^{\circ}\end{array}$ & $\begin{array}{l}\text { In front of } \\
\text { housing }\end{array}$ & $\begin{array}{l}\text { Improved semi-detached } \\
\text { home. }\end{array}$ \\
\hline $\begin{array}{l}\text { Norway } \\
\text { Maple }\end{array}$ & $\begin{array}{l}\text { Acer } \\
\text { platanoides }\end{array}$ & cankers on trunk & 1 & $\begin{array}{l}43.660043^{\circ}, \\
-79.448744^{\circ}\end{array}$ & $\begin{array}{l}\text { In front of } \\
\text { housing }\end{array}$ & $\begin{array}{l}\text { Improved semi-detached } \\
\text { home. }\end{array}$ \\
\hline $\begin{array}{l}\text { Norway } \\
\text { Maple }\end{array}$ & $\begin{array}{l}\text { Acer } \\
\text { platanoides }\end{array}$ & weak branch unions & 1 & $\begin{array}{l}43.660085^{\circ}, \\
-79.448768^{\circ}\end{array}$ & $\begin{array}{l}\text { In front of } \\
\text { housing }\end{array}$ & $\begin{array}{l}\text { Improved semi-detached } \\
\text { home. }\end{array}$ \\
\hline $\begin{array}{l}\text { Norway } \\
\text { Maple }\end{array}$ & $\begin{array}{l}\text { Acer } \\
\text { platanoides }\end{array}$ & good condition & 0 & $\begin{array}{l}43.660128^{\circ}, \\
-79.447786^{\circ}\end{array}$ & $\begin{array}{l}\text { In front of } \\
\text { housing }\end{array}$ & $\begin{array}{l}\text { Improved semi-detached } \\
\text { home. }\end{array}$ \\
\hline $\begin{array}{l}\text { Norway } \\
\text { Maple }\end{array}$ & $\begin{array}{l}\text { Acer } \\
\text { platanoides }\end{array}$ & good condition & 0 & $\begin{array}{l}43.660305^{\circ}, \\
-79.448010^{\circ}\end{array}$ & $\begin{array}{l}\text { In front of } \\
\text { housing }\end{array}$ & $\begin{array}{l}\text { Improved semi-detached } \\
\text { home. }\end{array}$ \\
\hline $\begin{array}{l}\text { Norway } \\
\text { Maple }\end{array}$ & $\begin{array}{l}\text { Acer } \\
\text { platanoides }\end{array}$ & cankers on trunk & 1 & $\begin{array}{l}43.660537^{\circ}, \\
-79.448131^{\circ}\end{array}$ & $\begin{array}{l}\text { In front of } \\
\text { housing }\end{array}$ & $\begin{array}{l}\text { Improved semi-detached } \\
\text { home. }\end{array}$ \\
\hline $\begin{array}{l}\text { Norway } \\
\text { Maple }\end{array}$ & $\begin{array}{l}\text { Acer } \\
\text { platanoides }\end{array}$ & good condition & 0 & $\begin{array}{l}43.660681^{\circ}, \\
-79.447150^{\circ} \\
\end{array}$ & $\begin{array}{l}\text { In front of } \\
\text { housing }\end{array}$ & $\begin{array}{l}\text { Improved semi-detached } \\
\text { home. }\end{array}$ \\
\hline $\begin{array}{l}\text { Norway } \\
\text { Maple }\end{array}$ & $\begin{array}{l}\text { Acer } \\
\text { platanoides }\end{array}$ & good condition & 0 & $\begin{array}{l}43.660773^{\circ}, \\
-79.448015^{\circ}\end{array}$ & $\begin{array}{l}\text { In front of } \\
\text { housing }\end{array}$ & $\begin{array}{l}\text { Improved semi-detached } \\
\text { home. }\end{array}$ \\
\hline $\begin{array}{l}\text { Norway } \\
\text { Maple }\end{array}$ & $\begin{array}{l}\text { Acer } \\
\text { platanoides }\end{array}$ & tree lean, cracks on trunk & 2 & $\begin{array}{l}43.660933^{\circ}, \\
-79.450589^{\circ}\end{array}$ & $\begin{array}{l}\text { In front of } \\
\text { housing }\end{array}$ & $\begin{array}{l}\text { Improved semi-detached } \\
\text { home. }\end{array}$ \\
\hline $\begin{array}{l}\text { Norway } \\
\text { Maple }\end{array}$ & $\begin{array}{l}\text { Acer } \\
\text { platanoides }\end{array}$ & cracks and cankers on trunk & 2 & $\begin{array}{l}43.660937^{\circ} \\
-79.450657^{\circ}\end{array}$ & $\begin{array}{l}\text { In front of } \\
\text { housing }\end{array}$ & $\begin{array}{l}\text { Improved semi-detached } \\
\text { home. }\end{array}$ \\
\hline $\begin{array}{l}\text { Norway } \\
\text { Maple }\end{array}$ & $\begin{array}{l}\text { Acer } \\
\text { platanoides }\end{array}$ & $\begin{array}{l}\text { tree lean, large crack along } \\
\text { tree }\end{array}$ & 2 & $\begin{array}{l}43.661354^{\circ}, \\
-79.448656^{\circ} \\
\end{array}$ & $\begin{array}{l}\text { In front of } \\
\text { housing }\end{array}$ & $\begin{array}{l}\text { Improved semi-detached } \\
\text { home. }\end{array}$ \\
\hline
\end{tabular}




\begin{tabular}{|c|c|c|c|c|c|c|}
\hline $\begin{array}{l}\text { Norway } \\
\text { Maple }\end{array}$ & $\begin{array}{l}\text { Acer } \\
\text { platanoides }\end{array}$ & good condition & 0 & $\begin{array}{l}43.661383^{\circ}, \\
-79.447442^{\circ} \\
\end{array}$ & $\begin{array}{l}\text { In front of } \\
\text { housing }\end{array}$ & $\begin{array}{l}\text { Improved semi-detached } \\
\text { home. }\end{array}$ \\
\hline $\begin{array}{l}\text { Norway } \\
\text { Maple }\end{array}$ & $\begin{array}{l}\text { Acer } \\
\text { platanoides }\end{array}$ & good condition & 0 & $\begin{array}{l}43.661383^{\circ}, \\
-79.447442^{\circ}\end{array}$ & $\begin{array}{l}\text { In front of } \\
\text { housing }\end{array}$ & $\begin{array}{l}\text { Improved semi-detached } \\
\text { home. }\end{array}$ \\
\hline $\begin{array}{l}\text { Norway } \\
\text { Maple }\end{array}$ & $\begin{array}{l}\text { Acer } \\
\text { platanoides }\end{array}$ & good condition & 0 & $\begin{array}{l}43.661428^{\circ}, \\
-79.447464^{\circ}\end{array}$ & $\begin{array}{l}\text { In front of } \\
\text { housing }\end{array}$ & $\begin{array}{l}\text { Improved semi-detached } \\
\text { home. }\end{array}$ \\
\hline $\begin{array}{l}\text { Norway } \\
\text { Maple }\end{array}$ & $\begin{array}{l}\text { Acer } \\
\text { platanoides }\end{array}$ & good condition & 0 & $\begin{array}{l}43.661493^{\circ}, \\
-79.447497^{\circ}\end{array}$ & $\begin{array}{l}\text { In front of } \\
\text { housing }\end{array}$ & $\begin{array}{l}\text { Improved semi-detached } \\
\text { home. }\end{array}$ \\
\hline $\begin{array}{l}\text { Norway } \\
\text { Maple }\end{array}$ & $\begin{array}{l}\text { Acer } \\
\text { platanoides }\end{array}$ & tree lean, cankers on trunk & 2 & $\begin{array}{l}43.658416^{\circ}, \\
-79.446612^{\circ}\end{array}$ & $\begin{array}{l}\text { In front of } \\
\text { housing }\end{array}$ & Row home. \\
\hline $\begin{array}{l}\text { Norway } \\
\text { Maple }\end{array}$ & $\begin{array}{l}\text { Acer } \\
\text { platanoides }\end{array}$ & tree lean & 1 & $\begin{array}{l}43.658442^{\circ}, \\
-79.446527^{\circ}\end{array}$ & $\begin{array}{l}\text { In front of } \\
\text { housing }\end{array}$ & Row home. \\
\hline $\begin{array}{l}\text { Norway } \\
\text { Maple }\end{array}$ & $\begin{array}{l}\text { Acer } \\
\text { platanoides }\end{array}$ & tree lean & 1 & $\begin{array}{l}43.658468^{\circ}, \\
-79.446420^{\circ}\end{array}$ & $\begin{array}{l}\text { In front of } \\
\text { housing }\end{array}$ & Row home. \\
\hline $\begin{array}{l}\text { Norway } \\
\text { Maple }\end{array}$ & $\begin{array}{l}\text { Acer } \\
\text { platanoides }\end{array}$ & good condition & 0 & $\begin{array}{l}43.660482^{\circ}, \\
-79.446891^{\circ}\end{array}$ & $\begin{array}{l}\text { In front of } \\
\text { housing }\end{array}$ & $\begin{array}{l}\text { Semi-detached home. } \\
\text { Renovation status unclear. }\end{array}$ \\
\hline $\begin{array}{l}\text { Norway } \\
\text { Maple }\end{array}$ & $\begin{array}{l}\text { Acer } \\
\text { platanoides }\end{array}$ & good condition & 0 & $\begin{array}{l}43.660510^{\circ}, \\
-79.447080^{\circ}\end{array}$ & $\begin{array}{l}\text { In front of } \\
\text { housing }\end{array}$ & $\begin{array}{l}\text { Semi-detached home. } \\
\text { Renovation status unclear. }\end{array}$ \\
\hline $\begin{array}{l}\text { Norway } \\
\text { Maple }\end{array}$ & $\begin{array}{l}\text { Acer } \\
\text { platanoides }\end{array}$ & $50 \%$ dieback & 2 & $\begin{array}{l}43.660603^{\circ}, \\
-79.447121^{\circ}\end{array}$ & $\begin{array}{l}\text { In front of } \\
\text { housing }\end{array}$ & $\begin{array}{l}\text { Semi-detached home. } \\
\text { Renovation status unclear. }\end{array}$ \\
\hline $\begin{array}{l}\text { Norway } \\
\text { Maple }\end{array}$ & $\begin{array}{l}\text { Acer } \\
\text { platanoides }\end{array}$ & good condition & 0 & $\begin{array}{l}43.660783^{\circ}, \\
-79.447183^{\circ}\end{array}$ & $\begin{array}{l}\text { In front of } \\
\text { housing }\end{array}$ & $\begin{array}{l}\text { Semi-detached home. } \\
\text { Renovation status unclear. }\end{array}$ \\
\hline $\begin{array}{l}\text { Norway } \\
\text { Maple }\end{array}$ & $\begin{array}{l}\text { Acer } \\
\text { platanoides }\end{array}$ & good condition & 0 & $\begin{array}{l}43.660901^{\circ}, \\
-79.447065^{\circ}\end{array}$ & $\begin{array}{l}\text { In front of } \\
\text { housing }\end{array}$ & $\begin{array}{l}\text { Semi-detached home. } \\
\text { Renovation status unclear. }\end{array}$ \\
\hline $\begin{array}{l}\text { Norway } \\
\text { Maple }\end{array}$ & $\begin{array}{l}\text { Acer } \\
\text { platanoides }\end{array}$ & cankers on trunk & 1 & $\begin{array}{l}43.661141^{\circ}, \\
-79.447328^{\circ}\end{array}$ & $\begin{array}{l}\text { In front of } \\
\text { housing }\end{array}$ & $\begin{array}{l}\text { Semi-detached home. } \\
\text { Renovation status unclear. }\end{array}$ \\
\hline $\begin{array}{l}\text { Norway } \\
\text { Maple }\end{array}$ & $\begin{array}{l}\text { Acer } \\
\text { platanoides }\end{array}$ & cankers on trunk & 1 & $\begin{array}{l}43.661193^{\circ}, \\
-79.447363^{\circ}\end{array}$ & $\begin{array}{l}\text { In front of } \\
\text { housing }\end{array}$ & $\begin{array}{l}\text { Semi-detached home. } \\
\text { Renovation status unclear. }\end{array}$ \\
\hline $\begin{array}{l}\text { Norway } \\
\text { Maple }\end{array}$ & $\begin{array}{l}\text { Acer } \\
\text { platanoides }\end{array}$ & good condition & 0 & $\begin{array}{l}43.661214^{\circ}, \\
-79.447189^{\circ}\end{array}$ & $\begin{array}{l}\text { In front of } \\
\text { housing }\end{array}$ & $\begin{array}{l}\text { Semi-detached home. } \\
\text { Renovation status unclear. }\end{array}$ \\
\hline $\begin{array}{l}\text { Norway } \\
\text { Maple }\end{array}$ & $\begin{array}{l}\text { Acer } \\
\text { platanoides }\end{array}$ & good condition & 0 & $\begin{array}{l}43.661295^{\circ}, \\
-79.447230^{\circ}\end{array}$ & $\begin{array}{l}\text { In front of } \\
\text { housing }\end{array}$ & $\begin{array}{l}\text { Semi-detached home. } \\
\text { Renovation status unclear. }\end{array}$ \\
\hline $\begin{array}{l}\text { Norway } \\
\text { Maple }\end{array}$ & $\begin{array}{l}\text { Acer } \\
\text { platanoides }\end{array}$ & good condition & 0 & $\begin{array}{l}43.657972^{\circ}, \\
-79.449846^{\circ}\end{array}$ & $\begin{array}{l}\text { In front of } \\
\text { housing }\end{array}$ & Stacked townhome. \\
\hline $\begin{array}{l}\text { Norway } \\
\text { Spruce }\end{array}$ & Picea abies & tree lean & 1 & $\begin{array}{l}43.659133^{\circ}, \\
-79.449674^{\circ}\end{array}$ & $\begin{array}{l}\text { In front of } \\
\text { housing }\end{array}$ & $\begin{array}{l}\text { New tree. Unimproved semi- } \\
\text { detached home. }\end{array}$ \\
\hline $\begin{array}{l}\text { Norway } \\
\text { Spruce }\end{array}$ & Picea abies & discoloured leaves & 1 & $\begin{array}{l}43.661279^{\circ}, \\
-79.449144^{\circ}\end{array}$ & $\begin{array}{l}\text { In front of } \\
\text { housing }\end{array}$ & $\begin{array}{l}\text { New tree. Unimproved semi- } \\
\text { detached home. }\end{array}$ \\
\hline $\begin{array}{l}\text { Norway } \\
\text { Spruce }\end{array}$ & Picea abies & good condition & 0 & $\begin{array}{l}43.658981^{\circ}, \\
-79.449576^{\circ}\end{array}$ & $\begin{array}{l}\text { In front of } \\
\text { housing }\end{array}$ & $\begin{array}{l}\text { New tree. Improved semi- } \\
\text { detached home. }\end{array}$ \\
\hline $\begin{array}{l}\text { Norway } \\
\text { Spruce }\end{array}$ & Picea abies & good condition & 0 & $\begin{array}{l}43.659386^{\circ}, \\
-79.446718^{\circ}\end{array}$ & $\begin{array}{l}\text { In front of } \\
\text { housing }\end{array}$ & $\begin{array}{l}\text { New tree. Improved semi- } \\
\text { detached home. }\end{array}$ \\
\hline $\begin{array}{l}\text { Norway } \\
\text { Spruce }\end{array}$ & Picea abies & good condition & 0 & $\begin{array}{l}43.661248^{\circ}, \\
-79.449171^{\circ}\end{array}$ & $\begin{array}{l}\text { In front of } \\
\text { housing }\end{array}$ & $\begin{array}{l}\text { New tree. Improved semi- } \\
\text { detached home. }\end{array}$ \\
\hline $\begin{array}{l}\text { Norway } \\
\text { Spruce }\end{array}$ & Picea abies & good condition & 0 & $\begin{array}{l}43.661266^{\circ}, \\
-79.449087^{\circ}\end{array}$ & $\begin{array}{l}\text { In front of } \\
\text { housing }\end{array}$ & $\begin{array}{l}\text { New tree. Improved semi- } \\
\text { detached home. }\end{array}$ \\
\hline $\begin{array}{l}\text { Norway } \\
\text { Spruce }\end{array}$ & Picea abies & good condition & 0 & $\begin{array}{l}43.661275^{\circ}, \\
-79.449152^{\circ}\end{array}$ & $\begin{array}{l}\text { In front of } \\
\text { housing }\end{array}$ & $\begin{array}{l}\text { New tree. Improved semi- } \\
\text { detached home. }\end{array}$ \\
\hline $\begin{array}{l}\text { Norway } \\
\text { Spruce }\end{array}$ & Picea abies & good condition & 0 & $\begin{array}{l}43.661275^{\circ}, \\
-79.449163^{\circ}\end{array}$ & $\begin{array}{l}\text { In front of } \\
\text { housing }\end{array}$ & $\begin{array}{l}\text { New tree. Improved semi- } \\
\text { detached home. }\end{array}$ \\
\hline $\begin{array}{l}\text { Norway } \\
\text { Spruce }\end{array}$ & Picea abies & good condition & 0 & $\begin{array}{l}43.661285^{\circ}, \\
-79.449111^{\circ}\end{array}$ & $\begin{array}{l}\text { In front of } \\
\text { housing }\end{array}$ & $\begin{array}{l}\text { New tree. Improved semi- } \\
\text { detached home. }\end{array}$ \\
\hline $\begin{array}{l}\text { Norway } \\
\text { Spruce }\end{array}$ & Picea abies & good condition & 0 & $\begin{array}{l}43.661287^{\circ} \\
-79.449105^{\circ}\end{array}$ & $\begin{array}{l}\text { In front of } \\
\text { housing }\end{array}$ & $\begin{array}{l}\text { New tree. Improved semi- } \\
\text { detached home. }\end{array}$ \\
\hline $\begin{array}{l}\text { Norway } \\
\text { Spruce }\end{array}$ & Picea abies & good condition & 0 & $\begin{array}{l}43.659536^{\circ}, \\
-79.446755^{\circ}\end{array}$ & $\begin{array}{l}\text { In front of } \\
\text { housing }\end{array}$ & $\begin{array}{l}\text { New tree. Semi-detached } \\
\text { home. Renovation status } \\
\text { unclear. }\end{array}$ \\
\hline $\begin{array}{l}\text { Norway } \\
\text { Spruce }\end{array}$ & Picea abies & good condition & 0 & $\begin{array}{l}43.659537^{\circ} \\
-79.446738^{\circ}\end{array}$ & $\begin{array}{l}\text { In front of } \\
\text { housing }\end{array}$ & $\begin{array}{l}\text { New tree. Semi-detached } \\
\text { home. Renovation status } \\
\text { unclear. }\end{array}$ \\
\hline $\begin{array}{l}\text { Norway } \\
\text { Spruce }\end{array}$ & Picea abies & good condition & 0 & $\begin{array}{l}43.659542^{\circ}, \\
-79.446724^{\circ}\end{array}$ & $\begin{array}{l}\text { In front of } \\
\text { housing }\end{array}$ & $\begin{array}{l}\text { New tree. Semi-detached } \\
\text { home. Renovation status } \\
\text { unclear. }\end{array}$ \\
\hline $\begin{array}{l}\text { Norway } \\
\text { Spruce }\end{array}$ & Picea abies & good condition & 0 & $\begin{array}{l}43.659545^{\circ} \\
-79.446713^{\circ}\end{array}$ & $\begin{array}{l}\text { In front of } \\
\text { housing }\end{array}$ & $\begin{array}{l}\text { New tree. Semi-detached } \\
\text { home. Renovation status } \\
\text { unclear. }\end{array}$ \\
\hline
\end{tabular}




\begin{tabular}{|c|c|c|c|c|c|c|}
\hline $\begin{array}{l}\text { Norway } \\
\text { Spruce }\end{array}$ & Picea abies & good condition & 0 & $\begin{array}{l}43.659549^{\circ}, \\
-79.446657^{\circ}\end{array}$ & $\begin{array}{l}\text { In front of } \\
\text { housing }\end{array}$ & $\begin{array}{l}\text { New tree. Semi-detached } \\
\text { home. Renovation status } \\
\text { unclear. }\end{array}$ \\
\hline $\begin{array}{l}\text { Norway } \\
\text { Spruce }\end{array}$ & Picea abies & good condition & 0 & $\begin{array}{l}43.658624^{\circ}, \\
-79.447330^{\circ}\end{array}$ & $\begin{array}{l}\text { In front of } \\
\text { housing }\end{array}$ & $\begin{array}{l}\text { Unimproved semi-detached } \\
\text { home. }\end{array}$ \\
\hline $\begin{array}{l}\text { Ohio } \\
\text { Buckeye }\end{array}$ & $\begin{array}{l}\text { Aesculus } \\
\text { glabra }\end{array}$ & good condition & 0 & $\begin{array}{l}43.658262^{\circ}, \\
-79.448245^{\circ}\end{array}$ & $\begin{array}{l}\text { In front of } \\
\text { housing }\end{array}$ & $\begin{array}{l}\text { New tree. Improved semi- } \\
\text { detached home. }\end{array}$ \\
\hline $\begin{array}{l}\text { Ohio } \\
\text { Buckeye }\end{array}$ & $\begin{array}{l}\text { Aesculus } \\
\text { glabra }\end{array}$ & good condition & 0 & $\begin{array}{l}43.660805^{\circ} \\
-79.450543^{\circ}\end{array}$ & $\begin{array}{l}\text { In front of } \\
\text { housing }\end{array}$ & $\begin{array}{l}\text { New tree. Improved semi- } \\
\text { detached home. }\end{array}$ \\
\hline $\begin{array}{l}\text { Ohio } \\
\text { Buckeye }\end{array}$ & $\begin{array}{l}\text { Aesculus } \\
\text { glabra }\end{array}$ & defoliation & 1 & $\begin{array}{l}43.660891^{\circ}, \\
-79.450381^{\circ}\end{array}$ & $\begin{array}{l}\text { In front of } \\
\text { housing }\end{array}$ & $\begin{array}{l}\text { New tree. Improved semi- } \\
\text { detached home. }\end{array}$ \\
\hline $\begin{array}{l}\text { Ohio } \\
\text { Buckeye }\end{array}$ & $\begin{array}{l}\text { Aesculus } \\
\text { glabra }\end{array}$ & good condition & 0 & $\begin{array}{l}43.658099^{\circ}, \\
-79.448172^{\circ}\end{array}$ & $\begin{array}{l}\text { In front of } \\
\text { housing }\end{array}$ & $\begin{array}{l}\text { New tree. Improved semi- } \\
\text { detached home. }\end{array}$ \\
\hline Paper Birch & $\begin{array}{l}\text { Betula } \\
\text { papyrifera }\end{array}$ & DEAD & 4 & $\begin{array}{l}43.657514^{\circ}, \\
-79.449790^{\circ}\end{array}$ & $\begin{array}{l}\text { In front of } \\
\text { housing }\end{array}$ & Low-rise apartment. \\
\hline Paper Birch & $\begin{array}{l}\text { Betula } \\
\text { papyrifera }\end{array}$ & good condition & 0 & $\begin{array}{l}43.657531^{\circ}, \\
-79.449737^{\circ}\end{array}$ & $\begin{array}{l}\text { In front of } \\
\text { housing }\end{array}$ & Low-rise apartment. \\
\hline Paper Birch & $\begin{array}{l}\text { Betula } \\
\text { papyrifera }\end{array}$ & DEAD & 4 & $\begin{array}{l}43.657583^{\circ} \\
-79.450095^{\circ}\end{array}$ & $\begin{array}{l}\text { In front of } \\
\text { housing }\end{array}$ & Low-rise apartment. \\
\hline Paper Birch & $\begin{array}{l}\text { Betula } \\
\text { papyrifera }\end{array}$ & tree lean & 1 & $\begin{array}{l}43.658450^{\circ}, \\
-79.448328^{\circ}\end{array}$ & $\begin{array}{l}\text { In front of } \\
\text { housing }\end{array}$ & $\begin{array}{l}\text { New tree. Unimproved semi- } \\
\text { detached home. }\end{array}$ \\
\hline Paper Birch & $\begin{array}{l}\text { Betula } \\
\text { papyrifera }\end{array}$ & good condition & 0 & $\begin{array}{l}43.660305^{\circ}, \\
-79.448105^{\circ}\end{array}$ & $\begin{array}{l}\text { In front of } \\
\text { housing }\end{array}$ & $\begin{array}{l}\text { New tree. Improved semi- } \\
\text { detached home. }\end{array}$ \\
\hline Paper Birch & $\begin{array}{l}\text { Betula } \\
\text { papyrifera }\end{array}$ & peeling bark & 1 & $\begin{array}{l}43.660841^{\circ}, \\
-79.451065^{\circ}\end{array}$ & $\begin{array}{l}\text { In front of } \\
\text { housing }\end{array}$ & $\begin{array}{l}\text { Improved semi-detached } \\
\text { home. }\end{array}$ \\
\hline Paper Birch & $\begin{array}{l}\text { Betula } \\
\text { papyrifera }\end{array}$ & good condition & 0 & $\begin{array}{l}43.660849^{\circ}, \\
-79.451033^{\circ}\end{array}$ & $\begin{array}{l}\text { In front of } \\
\text { housing }\end{array}$ & $\begin{array}{l}\text { Improved semi-detached } \\
\text { home. }\end{array}$ \\
\hline Peach Tree & Prunus persica & tree lean, defoliation & 2 & $\begin{array}{l}43.659519^{\circ}, \\
-79.450202^{\circ}\end{array}$ & $\begin{array}{l}\text { In front of } \\
\text { housing }\end{array}$ & $\begin{array}{l}\text { Unimproved semi-detached } \\
\text { home. }\end{array}$ \\
\hline Peach Tree & Prunus persica & dead/broken branches & 1 & $\begin{array}{l}43.659835^{\circ}, \\
-79.447858^{\circ}\end{array}$ & $\begin{array}{l}\text { In front of } \\
\text { housing }\end{array}$ & $\begin{array}{l}\text { Unimproved semi-detached } \\
\text { home. }\end{array}$ \\
\hline Red Maple & Acer rubrum & $\begin{array}{l}\text { cracks, weak branch } \\
\text { unions, } 90 \% \text { dieback }\end{array}$ & 3 & $\begin{array}{l}43.657314^{\circ}, \\
-79.449192^{\circ}\end{array}$ & $\begin{array}{l}\text { In front of } \\
\text { housing }\end{array}$ & $\begin{array}{l}\text { New tree. Low-rise } \\
\text { apartment. }\end{array}$ \\
\hline Red Maple & Acer rubrum & good condition & 0 & $\begin{array}{l}43.659157^{\circ}, \\
-79.449896^{\circ}\end{array}$ & $\begin{array}{l}\text { In front of } \\
\text { housing }\end{array}$ & $\begin{array}{l}\text { New tree. Unimproved semi- } \\
\text { detached home. }\end{array}$ \\
\hline Red Maple & Acer rubrum & good condition & 0 & $\begin{array}{l}43.660271^{\circ}, \\
-79.449095^{\circ}\end{array}$ & $\begin{array}{l}\text { In front of } \\
\text { housing }\end{array}$ & $\begin{array}{l}\text { New tree. Unimproved semi- } \\
\text { detached home. }\end{array}$ \\
\hline $\begin{array}{l}\text { Red } \\
\text { Mulberry }\end{array}$ & Morus rubra & tree lean, cracks on trunk & 2 & $\begin{array}{l}43.659609^{\circ}, \\
-79.450043^{\circ}\end{array}$ & $\begin{array}{l}\text { In front of } \\
\text { housing }\end{array}$ & $\begin{array}{l}\text { Unimproved semi-detached } \\
\text { home. }\end{array}$ \\
\hline $\begin{array}{l}\text { Red } \\
\text { Mulberry }\end{array}$ & Morus rubra & good condition & 0 & $\begin{array}{l}43.660908^{\circ}, \\
-79.447057^{\circ}\end{array}$ & $\begin{array}{l}\text { In front of } \\
\text { housing }\end{array}$ & $\begin{array}{l}\text { Improved semi-detached } \\
\text { home. }\end{array}$ \\
\hline Red Oak & Quercus rubra & good condition & 0 & $\begin{array}{l}43.660479^{\circ}, \\
-79.452372^{\circ}\end{array}$ & $\begin{array}{l}\text { In front of } \\
\text { housing }\end{array}$ & Low-rise apartment. \\
\hline Red Oak & Quercus rubra & good condition & 0 & $\begin{array}{l}43.658965^{\circ}, \\
-79.447470^{\circ}\end{array}$ & $\begin{array}{l}\text { In front of } \\
\text { housing }\end{array}$ & $\begin{array}{l}\text { New tree. Improved semi- } \\
\text { detached home. }\end{array}$ \\
\hline Red Oak & Quercus rubra & good condition & 0 & $\begin{array}{l}43.659234^{\circ}, \\
-79.449714^{\circ}\end{array}$ & $\begin{array}{l}\text { In front of } \\
\text { housing }\end{array}$ & $\begin{array}{l}\text { New tree. Improved semi- } \\
\text { detached home. }\end{array}$ \\
\hline Red Oak & Quercus rubra & tree lean, cracks on trunk & 2 & $\begin{array}{l}43.659759^{\circ}, \\
-79.447345^{\circ}\end{array}$ & $\begin{array}{l}\text { In front of } \\
\text { housing }\end{array}$ & $\begin{array}{l}\text { New tree. Improved semi- } \\
\text { detached home. }\end{array}$ \\
\hline Red Oak & Quercus rubra & good condition & 0 & $\begin{array}{l}43.660724^{\circ}, \\
-79.451671^{\circ}\end{array}$ & $\begin{array}{l}\text { In front of } \\
\text { housing }\end{array}$ & $\begin{array}{l}\text { New tree. Stacked } \\
\text { townhome. }\end{array}$ \\
\hline Red Oak & Quercus rubra & good condition & 0 & $\begin{array}{l}43.660896^{\circ}, \\
-79.448283^{\circ}\end{array}$ & $\begin{array}{l}\text { In front of } \\
\text { housing }\end{array}$ & $\begin{array}{l}\text { Unimproved semi-detached } \\
\text { home. }\end{array}$ \\
\hline Red Spruce & Picea rubens & tree lean, peeling bark & 2 & $\begin{array}{l}43.660694^{\circ}, \\
-79.448992^{\circ}\end{array}$ & $\begin{array}{l}\text { In front of } \\
\text { housing }\end{array}$ & $\begin{array}{l}\text { Unimproved semi-detached } \\
\text { home. }\end{array}$ \\
\hline Red Spruce & Picea rubens & good condition & 0 & $\begin{array}{l}43.659048^{\circ}, \\
-79.448570^{\circ}\end{array}$ & $\begin{array}{l}\text { In front of } \\
\text { housing }\end{array}$ & $\begin{array}{l}\text { Improved semi-detached } \\
\text { home. }\end{array}$ \\
\hline Redbud & $\begin{array}{l}\text { Cercis } \\
\text { canadensis }\end{array}$ & good condition & 0 & $\begin{array}{l}43.658916^{\circ} \\
-79.448540^{\circ}\end{array}$ & $\begin{array}{l}\text { In front of } \\
\text { housing }\end{array}$ & $\begin{array}{l}\text { New tree. Unimproved semi- } \\
\text { detached home. }\end{array}$ \\
\hline Redbud & $\begin{array}{l}\text { Cercis } \\
\text { canadensis }\end{array}$ & good condition & 0 & $\begin{array}{l}43.659233^{\circ}, \\
-79.447601^{\circ}\end{array}$ & $\begin{array}{l}\text { In front of } \\
\text { housing }\end{array}$ & $\begin{array}{l}\text { New tree. Improved semi- } \\
\text { detached home. }\end{array}$ \\
\hline Redbud & $\begin{array}{l}\text { Cercis } \\
\text { canadensis }\end{array}$ & good condition & 0 & $\begin{array}{l}43.659762^{\circ}, \\
-79.449903^{\circ}\end{array}$ & $\begin{array}{l}\text { In front of } \\
\text { housing }\end{array}$ & $\begin{array}{l}\text { New tree. Improved semi- } \\
\text { detached home. }\end{array}$ \\
\hline Redbud & $\begin{array}{l}\text { Cercis } \\
\text { canadensis }\end{array}$ & $\begin{array}{l}20 \% \text { dieback, some dead } \\
\text { branches }\end{array}$ & 2 & $\begin{array}{l}43.657979^{\circ}, \\
-79.449775^{\circ}\end{array}$ & $\begin{array}{l}\text { In front of } \\
\text { housing }\end{array}$ & $\begin{array}{l}\text { New tree. Stacked } \\
\text { townhome. }\end{array}$ \\
\hline Redbud & $\begin{array}{l}\text { Cercis } \\
\text { canadensis }\end{array}$ & $\begin{array}{l}20 \% \text { dieback, some dead } \\
\text { branches }\end{array}$ & 2 & $\begin{array}{l}43.658028^{\circ}, \\
-79.449637^{\circ}\end{array}$ & $\begin{array}{l}\text { In front of } \\
\text { housing }\end{array}$ & $\begin{array}{l}\text { New tree. Stacked } \\
\text { townhome. }\end{array}$ \\
\hline
\end{tabular}




\begin{tabular}{|c|c|c|c|c|c|c|}
\hline Redbud & $\begin{array}{l}\text { Cercis } \\
\text { canadensis }\end{array}$ & good condition & 0 & $\begin{array}{l}43.659481^{\circ}, \\
-79.448513^{\circ}\end{array}$ & $\begin{array}{l}\text { In front of } \\
\text { housing }\end{array}$ & $\begin{array}{l}\text { Improved semi-detached } \\
\text { home. }\end{array}$ \\
\hline Redbud & $\begin{array}{l}\text { Cercis } \\
\text { canadensis }\end{array}$ & cracks/cankers on trunk & 2 & $\begin{array}{l}43.660533^{\circ}, \\
-79.449161^{\circ}\end{array}$ & $\begin{array}{l}\text { In front of } \\
\text { housing }\end{array}$ & $\begin{array}{l}\text { Improved semi-detached } \\
\text { home. }\end{array}$ \\
\hline Redbud & $\begin{array}{l}\text { Cercis } \\
\text { canadensis }\end{array}$ & cankers on trunk & 1 & $\begin{array}{l}43.660562^{\circ}, \\
-79.449175^{\circ}\end{array}$ & $\begin{array}{l}\text { In front of } \\
\text { housing }\end{array}$ & $\begin{array}{l}\text { Improved semi-detached } \\
\text { home. }\end{array}$ \\
\hline $\begin{array}{l}\text { Siberian } \\
\text { Elm }\end{array}$ & Ulmus pumila & $\begin{array}{l}20 \% \text { dieback, defoliation, } \\
\text { small cracks on trunk, } \\
\text { peeling bark }\end{array}$ & 3 & $\begin{array}{l}43.657647^{\circ} \\
-79.449910^{\circ}\end{array}$ & $\begin{array}{l}\text { In front of } \\
\text { housing }\end{array}$ & Low-rise apartment. \\
\hline $\begin{array}{l}\text { Siberian } \\
\text { Elm }\end{array}$ & Ulmus pumila & $\begin{array}{l}20 \% \text { dieback, defoliation, } \\
\text { small cracks on trunk, } \\
\text { peeling bark }\end{array}$ & 3 & $\begin{array}{l}43.657705^{\circ} \\
-79.449658^{\circ}\end{array}$ & $\begin{array}{l}\text { In front of } \\
\text { housing }\end{array}$ & Low-rise apartment. \\
\hline $\begin{array}{l}\text { Siberian } \\
\text { Elm }\end{array}$ & Ulmus pumila & $\begin{array}{l}20 \% \text { dieback, small cracks } \\
\text { on trunk, peeling bark }\end{array}$ & 2 & $\begin{array}{l}43.657711^{\circ}, \\
-79.449582^{\circ}\end{array}$ & $\begin{array}{l}\text { In front of } \\
\text { housing }\end{array}$ & Low-rise apartment. \\
\hline $\begin{array}{l}\text { Siberian } \\
\text { Elm }\end{array}$ & Ulmus pumila & $\begin{array}{l}70 \% \text { dieback, dead/broken } \\
\text { branches }\end{array}$ & 3 & $\begin{array}{l}43.657705^{\circ}, \\
-79.449575^{\circ}\end{array}$ & $\begin{array}{l}\text { In front of } \\
\text { housing }\end{array}$ & $\begin{array}{l}\text { New tree. Stacked } \\
\text { townhome. }\end{array}$ \\
\hline $\begin{array}{l}\text { Siberian } \\
\text { Elm }\end{array}$ & Ulmus pumila & tree lean & 1 & $\begin{array}{l}43.659008^{\circ}, \\
-79.450182^{\circ}\end{array}$ & $\begin{array}{l}\text { In front of } \\
\text { housing }\end{array}$ & $\begin{array}{l}\text { Unimproved semi-detached } \\
\text { home. }\end{array}$ \\
\hline $\begin{array}{l}\text { Siberian } \\
\text { Elm }\end{array}$ & Ulmus pumila & $\begin{array}{l}\text { dead/broken branches, } \\
\text { defoliation }\end{array}$ & 2 & $\begin{array}{l}43.659076^{\circ}, \\
-79.449846^{\circ} \\
\end{array}$ & $\begin{array}{l}\text { In front of } \\
\text { housing }\end{array}$ & $\begin{array}{l}\text { Unimproved semi-detached } \\
\text { home. }\end{array}$ \\
\hline $\begin{array}{l}\text { Siberian } \\
\text { Elm }\end{array}$ & Ulmus pumila & defoliation & 1 & $\begin{array}{l}43.658645^{\circ}, \\
-79.450248^{\circ}\end{array}$ & $\begin{array}{l}\text { In front of } \\
\text { housing }\end{array}$ & $\begin{array}{l}\text { Improved semi-detached } \\
\text { home. }\end{array}$ \\
\hline $\begin{array}{l}\text { Siberian } \\
\text { Elm }\end{array}$ & Ulmus pumila & $\begin{array}{l}\text { tree lean, } 20 \% \text { dieback, } \\
\text { small cracks on trunk }\end{array}$ & 3 & $\begin{array}{l}43.658135^{\circ}, \\
-79.450443^{\circ}\end{array}$ & $\begin{array}{l}\text { In front of } \\
\text { housing }\end{array}$ & Stacked townhome. \\
\hline $\begin{array}{l}\text { Siberian } \\
\text { Elm }\end{array}$ & Ulmus pumila & $\begin{array}{l}\text { tree lean, } 20 \% \text { dieback, } \\
\text { small cracks on trunk }\end{array}$ & 3 & $\begin{array}{l}43.658269^{\circ}, \\
-79.450589^{\circ}\end{array}$ & $\begin{array}{l}\text { In front of } \\
\text { housing }\end{array}$ & Stacked townhome. \\
\hline $\begin{array}{l}\text { Siberian } \\
\text { Elm }\end{array}$ & Ulmus pumila & $\begin{array}{l}\text { tree lean, } 20 \% \text { dieback, } \\
\text { small cracks on trunk }\end{array}$ & 3 & $\begin{array}{l}43.658299^{\circ}, \\
-79.450618^{\circ}\end{array}$ & $\begin{array}{l}\text { In front of } \\
\text { housing }\end{array}$ & Stacked townhome. \\
\hline $\begin{array}{l}\text { Silver } \\
\text { Maple }\end{array}$ & $\begin{array}{l}\text { Acer } \\
\text { saccharinum }\end{array}$ & good condition & 0 & $\begin{array}{l}43.659331^{\circ}, \\
-79.449934^{\circ}\end{array}$ & $\begin{array}{l}\text { In front of } \\
\text { housing }\end{array}$ & Business. \\
\hline $\begin{array}{l}\text { Silver } \\
\text { Maple }\end{array}$ & $\begin{array}{l}\text { Acer } \\
\text { saccharinum }\end{array}$ & good condition & 0 & $\begin{array}{l}43.659153^{\circ}, \\
-79.449874^{\circ}\end{array}$ & $\begin{array}{l}\text { In front of } \\
\text { housing }\end{array}$ & New tree. Business. \\
\hline $\begin{array}{l}\text { Silver } \\
\text { Maple }\end{array}$ & $\begin{array}{l}\text { Acer } \\
\text { saccharinum }\end{array}$ & tree lean & 1 & $\begin{array}{l}43.658784^{\circ} \\
-79.448465^{\circ}\end{array}$ & $\begin{array}{l}\text { In front of } \\
\text { housing }\end{array}$ & $\begin{array}{l}\text { New tree. Improved semi- } \\
\text { detached home. }\end{array}$ \\
\hline $\begin{array}{l}\text { Silver } \\
\text { Maple }\end{array}$ & $\begin{array}{l}\text { Acer } \\
\text { saccharinum }\end{array}$ & good condition & 0 & $\begin{array}{l}43.658922^{\circ}, \\
-79.447468^{\circ}\end{array}$ & $\begin{array}{l}\text { In front of } \\
\text { housing }\end{array}$ & $\begin{array}{l}\text { New tree. Improved semi- } \\
\text { detached home. }\end{array}$ \\
\hline $\begin{array}{l}\text { Silver } \\
\text { Maple }\end{array}$ & $\begin{array}{l}\text { Acer } \\
\text { saccharinum }\end{array}$ & good condition & 0 & $\begin{array}{l}43.660176^{\circ}, \\
-79.450093^{\circ}\end{array}$ & $\begin{array}{l}\text { In front of } \\
\text { housing }\end{array}$ & $\begin{array}{l}\text { New tree. Improved semi- } \\
\text { detached home. }\end{array}$ \\
\hline $\begin{array}{l}\text { Silver } \\
\text { Maple }\end{array}$ & $\begin{array}{l}\text { Acer } \\
\text { saccharinum }\end{array}$ & good condition & 0 & $\begin{array}{l}43.660392^{\circ}, \\
-79.450146^{\circ}\end{array}$ & $\begin{array}{l}\text { In front of } \\
\text { housing }\end{array}$ & $\begin{array}{l}\text { New tree. Improved semi- } \\
\text { detached home. }\end{array}$ \\
\hline $\begin{array}{l}\text { Silver } \\
\text { Maple }\end{array}$ & $\begin{array}{l}\text { Acer } \\
\text { saccharinum }\end{array}$ & good condition & 0 & $\begin{array}{l}43.660623^{\circ} \\
-79.450283^{\circ}\end{array}$ & $\begin{array}{l}\text { In front of } \\
\text { housing }\end{array}$ & $\begin{array}{l}\text { New tree. Improved semi- } \\
\text { detached home. }\end{array}$ \\
\hline $\begin{array}{l}\text { Silver } \\
\text { Maple }\end{array}$ & $\begin{array}{l}\text { Acer } \\
\text { saccharinum }\end{array}$ & $\begin{array}{l}\text { cracks, cankers, } 10 \% \\
\text { dieback }\end{array}$ & 2 & $\begin{array}{l}43.658901^{\circ}, \\
-79.448511^{\circ}\end{array}$ & $\begin{array}{l}\text { In front of } \\
\text { housing }\end{array}$ & $\begin{array}{l}\text { Improved semi-detached } \\
\text { home. }\end{array}$ \\
\hline $\begin{array}{l}\text { Silver } \\
\text { Maple }\end{array}$ & $\begin{array}{l}\text { Acer } \\
\text { saccharinum }\end{array}$ & good condition & 0 & $\begin{array}{l}43.659099^{\circ}, \\
-79.449620^{\circ}\end{array}$ & $\begin{array}{l}\text { In front of } \\
\text { housing }\end{array}$ & $\begin{array}{l}\text { Improved semi-detached } \\
\text { home. }\end{array}$ \\
\hline $\begin{array}{l}\text { Silver } \\
\text { Maple }\end{array}$ & $\begin{array}{l}\text { Acer } \\
\text { saccharinum }\end{array}$ & dead/broken branches & 1 & $\begin{array}{l}43.659722^{\circ}, \\
-79.449889^{\circ}\end{array}$ & $\begin{array}{l}\text { In front of } \\
\text { housing }\end{array}$ & $\begin{array}{l}\text { Improved semi-detached } \\
\text { home. }\end{array}$ \\
\hline $\begin{array}{l}\text { Silver } \\
\text { Maple }\end{array}$ & $\begin{array}{l}\text { Acer } \\
\text { saccharinum }\end{array}$ & peeling bark & 1 & $\begin{array}{l}43.660898^{\circ}, \\
-79.449110^{\circ}\end{array}$ & $\begin{array}{l}\text { In front of } \\
\text { housing }\end{array}$ & $\begin{array}{l}\text { Improved semi-detached } \\
\text { home. }\end{array}$ \\
\hline $\begin{array}{l}\text { Silver } \\
\text { Maple }\end{array}$ & $\begin{array}{l}\text { Acer } \\
\text { saccharinum }\end{array}$ & tree lean, $10 \%$ dieback & 2 & $\begin{array}{l}43.658263^{\circ}, \\
-79.447255^{\circ}\end{array}$ & $\begin{array}{l}\text { In front of } \\
\text { housing }\end{array}$ & Row home. \\
\hline Sugar Maple & $\begin{array}{l}\text { Acer } \\
\text { saccharum }\end{array}$ & good condition & 0 & $\begin{array}{l}43.657978^{\circ}, \\
-79.446336^{\circ}\end{array}$ & $\begin{array}{l}\text { In front of } \\
\text { housing }\end{array}$ & $\begin{array}{l}\text { New tree. Low-rise } \\
\text { apartment. }\end{array}$ \\
\hline Sugar Maple & $\begin{array}{l}\text { Acer } \\
\text { saccharum }\end{array}$ & good condition & 0 & $\begin{array}{l}43.658002^{\circ}, \\
-79.446289^{\circ}\end{array}$ & $\begin{array}{l}\text { In front of } \\
\text { housing }\end{array}$ & $\begin{array}{l}\text { New tree. Low-rise } \\
\text { apartment. }\end{array}$ \\
\hline Sugar Maple & $\begin{array}{l}\text { Acer } \\
\text { saccharum }\end{array}$ & good condition & 0 & $\begin{array}{l}43.658030^{\circ}, \\
-79.446241^{\circ}\end{array}$ & $\begin{array}{l}\text { In front of } \\
\text { housing }\end{array}$ & $\begin{array}{l}\text { New tree. Low-rise } \\
\text { apartment. }\end{array}$ \\
\hline Sugar Maple & $\begin{array}{l}\text { Acer } \\
\text { saccharum }\end{array}$ & good condition & 0 & $\begin{array}{l}43.658076^{\circ}, \\
-79.446435^{\circ}\end{array}$ & $\begin{array}{l}\text { In front of } \\
\text { housing }\end{array}$ & $\begin{array}{l}\text { New tree. Low-rise } \\
\text { apartment. }\end{array}$ \\
\hline Sugar Maple & $\begin{array}{l}\text { Acer } \\
\text { saccharum }\end{array}$ & good condition & 0 & $\begin{array}{l}43.658089^{\circ}, \\
-79.446246^{\circ}\end{array}$ & $\begin{array}{l}\text { In front of } \\
\text { housing }\end{array}$ & $\begin{array}{l}\text { New tree. Low-rise } \\
\text { apartment. }\end{array}$ \\
\hline Sugar Maple & $\begin{array}{l}\text { Acer } \\
\text { saccharum }\end{array}$ & good condition & 0 & $\begin{array}{l}43.658094^{\circ}, \\
-79.446363^{\circ}\end{array}$ & $\begin{array}{l}\text { In front of } \\
\text { housing }\end{array}$ & $\begin{array}{l}\text { New tree. Low-rise } \\
\text { apartment. }\end{array}$ \\
\hline Sugar Maple & $\begin{array}{l}\text { Acer } \\
\text { saccharum }\end{array}$ & peeling bark & 1 & $\begin{array}{l}43.660322^{\circ}, \\
-79.448833^{\circ}\end{array}$ & $\begin{array}{l}\text { In front of } \\
\text { housing }\end{array}$ & $\begin{array}{l}\text { New tree. Improved semi- } \\
\text { detached home. }\end{array}$ \\
\hline Sugar Maple & $\begin{array}{l}\text { Acer } \\
\text { saccharum }\end{array}$ & good condition & 0 & $\begin{array}{l}43.658020^{\circ}, \\
-79.449874^{\circ}\end{array}$ & $\begin{array}{l}\text { In front of } \\
\text { housing }\end{array}$ & $\begin{array}{l}\text { New tree. Stacked } \\
\text { townhome. }\end{array}$ \\
\hline
\end{tabular}




\begin{tabular}{|c|c|c|c|c|c|c|}
\hline Sugar Maple & $\begin{array}{l}\text { Acer } \\
\text { saccharum }\end{array}$ & good condition & 0 & $\begin{array}{l}43.658053^{\circ}, \\
-79.449882^{\circ}\end{array}$ & $\begin{array}{l}\text { In front of } \\
\text { housing }\end{array}$ & $\begin{array}{l}\text { New tree. Stacked } \\
\text { townhome. }\end{array}$ \\
\hline Sugar Maple & $\begin{array}{l}\text { Acer } \\
\text { saccharum }\end{array}$ & good condition & 0 & $\begin{array}{l}43.658109^{\circ}, \\
-79.449905^{\circ}\end{array}$ & $\begin{array}{l}\text { In front of } \\
\text { housing }\end{array}$ & $\begin{array}{l}\text { New tree. Stacked } \\
\text { townhome. }\end{array}$ \\
\hline Sugar Maple & $\begin{array}{l}\text { Acer } \\
\text { saccharum }\end{array}$ & good condition & 0 & $\begin{array}{l}43.658173^{\circ}, \\
-79.449927^{\circ}\end{array}$ & $\begin{array}{l}\text { In front of } \\
\text { housing }\end{array}$ & $\begin{array}{l}\text { New tree. Stacked } \\
\text { townhome. }\end{array}$ \\
\hline Sugar Maple & $\begin{array}{l}\text { Acer } \\
\text { saccharum }\end{array}$ & good condition & 0 & $\begin{array}{l}43.658246^{\circ}, \\
-79.449958^{\circ}\end{array}$ & $\begin{array}{l}\text { In front of } \\
\text { housing }\end{array}$ & $\begin{array}{l}\text { New tree. Stacked } \\
\text { townhome. }\end{array}$ \\
\hline Sugar Maple & $\begin{array}{l}\text { Acer } \\
\text { saccharum }\end{array}$ & good condition & 0 & $\begin{array}{l}43.658592^{\circ}, \\
-79.449639^{\circ}\end{array}$ & $\begin{array}{l}\text { In front of } \\
\text { housing }\end{array}$ & $\begin{array}{l}\text { New tree. Stacked } \\
\text { townhome. }\end{array}$ \\
\hline Sugar Maple & $\begin{array}{l}\text { Acer } \\
\text { saccharum }\end{array}$ & small cracks on trunk & 1 & $\begin{array}{l}43.658396^{\circ}, \\
-79.449359^{\circ}\end{array}$ & $\begin{array}{l}\text { In front of } \\
\text { housing }\end{array}$ & $\begin{array}{l}\text { Improved semi-detached } \\
\text { home. }\end{array}$ \\
\hline Sugar Maple & $\begin{array}{l}\text { Acer } \\
\text { saccharum }\end{array}$ & peeling bark & 1 & $\begin{array}{l}43.660348^{\circ}, \\
-79.448854^{\circ}\end{array}$ & $\begin{array}{l}\text { In front of } \\
\text { housing }\end{array}$ & $\begin{array}{l}\text { Improved semi-detached } \\
\text { home. }\end{array}$ \\
\hline $\begin{array}{l}\text { Swedish } \\
\text { White Beam }\end{array}$ & $\begin{array}{l}\text { Sorbus } \\
\text { intermedia }\end{array}$ & tree lean & 1 & $\begin{array}{l}43.657338^{\circ}, \\
-79.449133^{\circ}\end{array}$ & $\begin{array}{l}\text { In front of } \\
\text { housing }\end{array}$ & Low-rise apartment. \\
\hline Sweet Gum & $\begin{array}{l}\text { Liquidambar } \\
\text { styraciflua }\end{array}$ & good condition & 0 & $\begin{array}{l}43.658211^{\circ}, \\
-79.446836^{\circ}\end{array}$ & $\begin{array}{l}\text { In front of } \\
\text { housing }\end{array}$ & New tree. Row home. \\
\hline $\begin{array}{l}\text { Tree of } \\
\text { Heaven }\end{array}$ & $\begin{array}{l}\text { Ailanthus } \\
\text { altissima }\end{array}$ & good condition & 0 & $\begin{array}{l}43.657630^{\circ}, \\
-79.449790^{\circ}\end{array}$ & $\begin{array}{l}\text { In front of } \\
\text { housing }\end{array}$ & $\begin{array}{l}\text { New tree. Low-rise } \\
\text { apartment. }\end{array}$ \\
\hline $\begin{array}{l}\text { Tree of } \\
\text { Heaven }\end{array}$ & $\begin{array}{l}\text { Gleditsia } \\
\text { triacanthos }\end{array}$ & tree lean & 1 & $\begin{array}{l}43.659620^{\circ}, \\
-79.450235^{\circ}\end{array}$ & $\begin{array}{l}\text { In front of } \\
\text { housing }\end{array}$ & $\begin{array}{l}\text { New tree. Unimproved semi- } \\
\text { detached home. }\end{array}$ \\
\hline $\begin{array}{l}\text { Tree of } \\
\text { Heaven }\end{array}$ & $\begin{array}{l}\text { Ailanthus } \\
\text { altissima }\end{array}$ & tree lean & 1 & $\begin{array}{l}43.660103^{\circ} \\
-79.447396^{\circ}\end{array}$ & $\begin{array}{l}\text { In front of } \\
\text { housing }\end{array}$ & $\begin{array}{l}\text { New tree. Unimproved semi- } \\
\text { detached home. }\end{array}$ \\
\hline $\begin{array}{l}\text { Tree of } \\
\text { Heaven }\end{array}$ & $\begin{array}{l}\text { Ailanthus } \\
\text { altissima }\end{array}$ & good condition & 0 & $\begin{array}{l}43.657830^{\circ}, \\
-79.447371^{\circ}\end{array}$ & $\begin{array}{l}\text { In front of } \\
\text { housing }\end{array}$ & New tree. Row home. \\
\hline $\begin{array}{l}\text { Tree of } \\
\text { Heaven }\end{array}$ & $\begin{array}{l}\text { Ailanthus } \\
\text { altissima }\end{array}$ & good condition & 0 & $\begin{array}{l}43.657865^{\circ}, \\
-79.447472^{\circ}\end{array}$ & $\begin{array}{l}\text { In front of } \\
\text { housing }\end{array}$ & New tree. Row home. \\
\hline $\begin{array}{l}\text { Tree of } \\
\text { Heaven }\end{array}$ & $\begin{array}{l}\text { Ailanthus } \\
\text { altissima }\end{array}$ & good condition & 0 & $\begin{array}{l}43.657886^{\circ}, \\
-79.447362^{\circ}\end{array}$ & $\begin{array}{l}\text { In front of } \\
\text { housing }\end{array}$ & New tree. Row home. \\
\hline $\begin{array}{l}\text { Tree of } \\
\text { Heaven }\end{array}$ & $\begin{array}{l}\text { Ailanthus } \\
\text { altissima }\end{array}$ & good condition & 0 & $\begin{array}{l}43.658245^{\circ}, \\
-79.446702^{\circ}\end{array}$ & $\begin{array}{l}\text { In front of } \\
\text { housing }\end{array}$ & New tree. Row home. \\
\hline $\begin{array}{l}\text { Tree of } \\
\text { Heaven }\end{array}$ & $\begin{array}{l}\text { Gleditsia } \\
\text { triacanthos }\end{array}$ & tree lean & 1 & $\begin{array}{l}43.658764^{\circ}, \\
-79.446428^{\circ}\end{array}$ & $\begin{array}{l}\text { In front of } \\
\text { housing }\end{array}$ & $\begin{array}{l}\text { New tree. Semi-detached } \\
\text { home. Renovation status } \\
\text { unclear. }\end{array}$ \\
\hline $\begin{array}{l}\text { Tree of } \\
\text { Heaven }\end{array}$ & $\begin{array}{l}\text { Ailanthus } \\
\text { altissima }\end{array}$ & good condition & 0 & $\begin{array}{l}43.657394^{\circ}, \\
-79.448927^{\circ}\end{array}$ & $\begin{array}{l}\text { In front of } \\
\text { housing }\end{array}$ & $\begin{array}{l}\text { Improved semi-detached } \\
\text { home. }\end{array}$ \\
\hline $\begin{array}{l}\text { Tree of } \\
\text { Heaven }\end{array}$ & $\begin{array}{l}\text { Ailanthus } \\
\text { altissima }\end{array}$ & good condition & 0 & $\begin{array}{l}43.658555^{\circ}, \\
-79.450697^{\circ}\end{array}$ & $\begin{array}{l}\text { In front of } \\
\text { housing }\end{array}$ & $\begin{array}{l}\text { Improved semi-detached } \\
\text { home. }\end{array}$ \\
\hline $\begin{array}{l}\text { Tree of } \\
\text { Heaven }\end{array}$ & $\begin{array}{l}\text { Ailanthus } \\
\text { altissima }\end{array}$ & tree lean & 1 & $\begin{array}{l}43.660122^{\circ}, \\
-79.448219^{\circ}\end{array}$ & $\begin{array}{l}\text { In front of } \\
\text { housing }\end{array}$ & $\begin{array}{l}\text { Improved semi-detached } \\
\text { home. }\end{array}$ \\
\hline $\begin{array}{l}\text { Tree of } \\
\text { Heaven }\end{array}$ & $\begin{array}{l}\text { Ailanthus } \\
\text { altissima }\end{array}$ & tree lean, cankers on trunk & 2 & $\begin{array}{l}43.660199^{\circ}, \\
-79.448289^{\circ}\end{array}$ & $\begin{array}{l}\text { In front of } \\
\text { housing }\end{array}$ & $\begin{array}{l}\text { Improved semi-detached } \\
\text { home. }\end{array}$ \\
\hline $\begin{array}{l}\text { Tree of } \\
\text { Heaven }\end{array}$ & $\begin{array}{l}\text { Ailanthus } \\
\text { altissima }\end{array}$ & tree lean, defoliation & 2 & $\begin{array}{l}43.660230^{\circ}, \\
-79.448390^{\circ}\end{array}$ & $\begin{array}{l}\text { In front of } \\
\text { housing }\end{array}$ & $\begin{array}{l}\text { Improved semi-detached } \\
\text { home. }\end{array}$ \\
\hline $\begin{array}{l}\text { Tree of } \\
\text { Heaven }\end{array}$ & $\begin{array}{l}\text { Ailanthus } \\
\text { altissima }\end{array}$ & tree lean, cracks on trunk & 2 & $\begin{array}{l}43.660239^{\circ}, \\
-79.447750^{\circ} \\
\end{array}$ & $\begin{array}{l}\text { In front of } \\
\text { housing }\end{array}$ & $\begin{array}{l}\text { Improved semi-detached } \\
\text { home. }\end{array}$ \\
\hline $\begin{array}{l}\text { Tree of } \\
\text { Heaven }\end{array}$ & $\begin{array}{l}\text { Ailanthus } \\
\text { altissima }\end{array}$ & tree lean, cracks on trunk & 2 & $\begin{array}{l}43.660286^{\circ}, \\
-79.447525^{\circ}\end{array}$ & $\begin{array}{l}\text { In front of } \\
\text { housing }\end{array}$ & $\begin{array}{l}\text { Improved semi-detached } \\
\text { home. }\end{array}$ \\
\hline Tulip Tree & $\begin{array}{l}\text { Liriodendron } \\
\text { tulipifera }\end{array}$ & good condition & 0 & $\begin{array}{l}43.660907^{\circ}, \\
-79.448287^{\circ}\end{array}$ & $\begin{array}{l}\text { In front of } \\
\text { housing }\end{array}$ & $\begin{array}{l}\text { New tree. Unimproved semi- } \\
\text { detached home. }\end{array}$ \\
\hline Tulip Tree & $\begin{array}{l}\text { Liriodendron } \\
\text { tulipifera }\end{array}$ & good condition & 0 & $\begin{array}{l}43.658152^{\circ}, \\
-79.449274^{\circ}\end{array}$ & $\begin{array}{l}\text { In front of } \\
\text { housing }\end{array}$ & $\begin{array}{l}\text { New tree. Improved semi- } \\
\text { detached home. }\end{array}$ \\
\hline Tulip Tree & $\begin{array}{l}\text { Liriodendron } \\
\text { tulipifera }\end{array}$ & good condition & 0 & $\begin{array}{l}43.660819^{\circ}, \\
-79.450355^{\circ}\end{array}$ & $\begin{array}{l}\text { In front of } \\
\text { housing }\end{array}$ & $\begin{array}{l}\text { New tree. Improved semi- } \\
\text { detached home. }\end{array}$ \\
\hline $\begin{array}{l}\text { Weeping } \\
\text { Cypress }\end{array}$ & $\begin{array}{l}\text { Cupressus } \\
\text { nootkatensis }\end{array}$ & good condition & 0 & $\begin{array}{l}43.659140^{\circ}, \\
-79.449645^{\circ}\end{array}$ & $\begin{array}{l}\text { In front of } \\
\text { housing }\end{array}$ & $\begin{array}{l}\text { New tree. Improved semi- } \\
\text { detached home. }\end{array}$ \\
\hline $\begin{array}{l}\text { Weeping } \\
\text { Cypress }\end{array}$ & $\begin{array}{l}\text { Cupressus } \\
\text { nootkatensis }\end{array}$ & good condition & 0 & $\begin{array}{l}43.660092^{\circ}, \\
-79.446730^{\circ}\end{array}$ & $\begin{array}{l}\text { In front of } \\
\text { housing }\end{array}$ & $\begin{array}{l}\text { New tree. Improved semi- } \\
\text { detached home. }\end{array}$ \\
\hline $\begin{array}{l}\text { Weeping } \\
\text { Cypress }\end{array}$ & $\begin{array}{l}\text { Cupressus } \\
\text { nootkatensis }\end{array}$ & broken branches & 1 & $\begin{array}{l}43.659991^{\circ}, \\
-79.449962^{\circ}\end{array}$ & $\begin{array}{l}\text { In front of } \\
\text { housing }\end{array}$ & $\begin{array}{l}\text { Improved semi-detached } \\
\text { home. }\end{array}$ \\
\hline $\begin{array}{l}\text { White } \\
\text { Mulberry }\end{array}$ & Morus alba & good condition & 0 & $\begin{array}{l}43.659779^{\circ}, \\
-79.447904^{\circ}\end{array}$ & $\begin{array}{l}\text { In front of } \\
\text { housing }\end{array}$ & $\begin{array}{l}\text { New tree. Unimproved semi- } \\
\text { detached home. }\end{array}$ \\
\hline $\begin{array}{l}\text { White } \\
\text { Mulberry }\end{array}$ & Morus alba & good condition & 0 & $\begin{array}{l}43.660316^{\circ}, \\
-79.448066^{\circ}\end{array}$ & $\begin{array}{l}\text { In front of } \\
\text { housing }\end{array}$ & $\begin{array}{l}\text { New tree. Improved semi- } \\
\text { detached home. }\end{array}$ \\
\hline $\begin{array}{l}\text { White } \\
\text { Mulberry }\end{array}$ & Morus alba & tree lean & 1 & $\begin{array}{l}43.659644^{\circ}, \\
-79.449693^{\circ}\end{array}$ & $\begin{array}{l}\text { In front of } \\
\text { housing }\end{array}$ & $\begin{array}{l}\text { Improved semi-detached } \\
\text { home. }\end{array}$ \\
\hline
\end{tabular}




\begin{tabular}{|c|c|c|c|c|c|c|}
\hline $\begin{array}{l}\text { White } \\
\text { Mulberry }\end{array}$ & Morus alba & good condition & 0 & $\begin{array}{l}43.659848^{\circ}, \\
-79.450196^{\circ}\end{array}$ & $\begin{array}{l}\text { In front of } \\
\text { housing }\end{array}$ & $\begin{array}{l}\text { New tree. Unimproved semi- } \\
\text { detached home. }\end{array}$ \\
\hline $\begin{array}{l}\text { White } \\
\text { Mulberry }\end{array}$ & Morus alba & tree lean & 1 & $\begin{array}{l}43.660830^{\circ}, \\
-79.451223^{\circ}\end{array}$ & $\begin{array}{l}\text { In front of } \\
\text { housing }\end{array}$ & $\begin{array}{l}\text { New tree. Unimproved semi- } \\
\text { detached home. }\end{array}$ \\
\hline $\begin{array}{l}\text { White } \\
\text { Mulberry }\end{array}$ & Morus alba & cracks on trunk & 1 & $\begin{array}{l}43.659367^{\circ}, \\
-79.446668^{\circ}\end{array}$ & $\begin{array}{l}\text { In front of } \\
\text { housing }\end{array}$ & $\begin{array}{l}\text { New tree. Improved semi- } \\
\text { detached home. }\end{array}$ \\
\hline $\begin{array}{l}\text { White } \\
\text { Mulberry }\end{array}$ & Morus alba & good condition & 0 & $\begin{array}{l}43.660321^{\circ}, \\
-79.450342^{\circ}\end{array}$ & $\begin{array}{l}\text { In front of } \\
\text { housing }\end{array}$ & $\begin{array}{l}\text { New tree. Improved semi- } \\
\text { detached home. }\end{array}$ \\
\hline $\begin{array}{l}\text { White } \\
\text { Mulberry }\end{array}$ & Morus alba & good condition & 0 & $\begin{array}{l}43.660718^{\circ} \\
-79.447168^{\circ}\end{array}$ & $\begin{array}{l}\text { In front of } \\
\text { housing }\end{array}$ & $\begin{array}{l}\text { New tree. Semi-detached } \\
\text { home. Renovation status } \\
\text { unclear. }\end{array}$ \\
\hline $\begin{array}{l}\text { White } \\
\text { Mulberry }\end{array}$ & Morus alba & good condition & 0 & $\begin{array}{l}43.661649^{\circ} \\
-79.447277^{\circ}\end{array}$ & $\begin{array}{l}\text { In front of } \\
\text { housing }\end{array}$ & $\begin{array}{l}\text { New tree. Semi-detached } \\
\text { home. Renovation status } \\
\text { unclear. }\end{array}$ \\
\hline $\begin{array}{l}\text { White } \\
\text { Mulberry }\end{array}$ & Morus alba & good condition & 0 & $\begin{array}{l}43.661679^{\circ} \\
-79.447174^{\circ}\end{array}$ & $\begin{array}{l}\text { In front of } \\
\text { housing }\end{array}$ & $\begin{array}{l}\text { New tree. Semi-detached } \\
\text { home. Renovation status } \\
\text { unclear. }\end{array}$ \\
\hline $\begin{array}{l}\text { White } \\
\text { Mulberry }\end{array}$ & Morus alba & good condition & 0 & $\begin{array}{l}43.658046^{\circ}, \\
-79.448142^{\circ}\end{array}$ & $\begin{array}{l}\text { In front of } \\
\text { housing }\end{array}$ & $\begin{array}{l}\text { Improved semi-detached } \\
\text { home. }\end{array}$ \\
\hline $\begin{array}{l}\text { White } \\
\text { Spruce }\end{array}$ & Picea glauca & good condition & 0 & $\begin{array}{l}43.657985^{\circ}, \\
-79.448132^{\circ}\end{array}$ & $\begin{array}{l}\text { In front of } \\
\text { housing }\end{array}$ & $\begin{array}{l}\text { New tree. Improved semi- } \\
\text { detached home. }\end{array}$ \\
\hline $\begin{array}{l}\text { White } \\
\text { Spruce }\end{array}$ & Picea glauca & good condition & 0 & $\begin{array}{l}43.658144^{\circ}, \\
-79.448195^{\circ} \\
\end{array}$ & $\begin{array}{l}\text { In front of } \\
\text { housing }\end{array}$ & $\begin{array}{l}\text { New tree. Improved semi- } \\
\text { detached home. }\end{array}$ \\
\hline $\begin{array}{l}\text { White } \\
\text { Spruce }\end{array}$ & Picea glauca & tree lean & 1 & $\begin{array}{l}43.658869^{\circ}, \\
-79.448229^{\circ}\end{array}$ & $\begin{array}{l}\text { In front of } \\
\text { housing }\end{array}$ & $\begin{array}{l}\text { New tree. Improved semi- } \\
\text { detached home. }\end{array}$ \\
\hline $\begin{array}{l}\text { White } \\
\text { Spruce }\end{array}$ & Picea glauca & $10 \%$ dieback & 1 & $\begin{array}{l}43.658994^{\circ}, \\
-79.448321^{\circ}\end{array}$ & $\begin{array}{l}\text { In front of } \\
\text { housing }\end{array}$ & $\begin{array}{l}\text { New tree. Improved semi- } \\
\text { detached home. }\end{array}$ \\
\hline $\begin{array}{l}\text { White } \\
\text { Spruce }\end{array}$ & Picea glauca & good condition & 0 & $\begin{array}{l}43.660010^{\circ}, \\
-79.448983^{\circ}\end{array}$ & $\begin{array}{l}\text { In front of } \\
\text { housing }\end{array}$ & $\begin{array}{l}\text { New tree. Improved semi- } \\
\text { detached home. }\end{array}$ \\
\hline $\begin{array}{l}\text { White } \\
\text { Spruce }\end{array}$ & Picea glauca & good condition & 0 & $\begin{array}{l}43.660090^{\circ}, \\
-79.449035^{\circ}\end{array}$ & $\begin{array}{l}\text { In front of } \\
\text { housing }\end{array}$ & $\begin{array}{l}\text { New tree. Improved semi- } \\
\text { detached home. }\end{array}$ \\
\hline $\begin{array}{l}\text { White } \\
\text { Spruce }\end{array}$ & Picea glauca & good condition & 0 & $\begin{array}{l}43.660136^{\circ}, \\
-79.449369^{\circ}\end{array}$ & $\begin{array}{l}\text { In front of } \\
\text { housing }\end{array}$ & $\begin{array}{l}\text { New tree. Improved semi- } \\
\text { detached home. }\end{array}$ \\
\hline $\begin{array}{l}\text { White } \\
\text { Spruce }\end{array}$ & Picea glauca & good condition & 0 & $\begin{array}{l}43.660619^{\circ}, \\
-79.448169^{\circ}\end{array}$ & $\begin{array}{l}\text { In front of } \\
\text { housing }\end{array}$ & $\begin{array}{l}\text { New tree. Improved semi- } \\
\text { detached home. }\end{array}$ \\
\hline $\begin{array}{l}\text { White } \\
\text { Spruce }\end{array}$ & Picea glauca & good condition & 0 & $\begin{array}{l}43.660645^{\circ}, \\
-79.450517^{\circ}\end{array}$ & $\begin{array}{l}\text { In front of } \\
\text { housing }\end{array}$ & $\begin{array}{l}\text { New tree. Improved semi- } \\
\text { detached home. }\end{array}$ \\
\hline $\begin{array}{l}\text { White } \\
\text { Spruce }\end{array}$ & Picea glauca & dead/broken branches & 2 & $\begin{array}{l}43.660667^{\circ}, \\
-79.450527^{\circ}\end{array}$ & $\begin{array}{l}\text { In front of } \\
\text { housing }\end{array}$ & $\begin{array}{l}\text { New tree. Improved semi- } \\
\text { detached home. }\end{array}$ \\
\hline $\begin{array}{l}\text { White } \\
\text { Spruce }\end{array}$ & Picea glauca & good condition & 0 & $\begin{array}{l}43.659790^{\circ}, \\
-79.452039^{\circ}\end{array}$ & $\begin{array}{l}\text { In front of } \\
\text { housing }\end{array}$ & $\begin{array}{l}\text { New tree. Stacked } \\
\text { townhome. }\end{array}$ \\
\hline $\begin{array}{l}\text { White } \\
\text { Spruce }\end{array}$ & Picea glauca & good condition & 0 & $\begin{array}{l}43.659808^{\circ}, \\
-79.452148^{\circ}\end{array}$ & $\begin{array}{l}\text { In front of } \\
\text { housing }\end{array}$ & $\begin{array}{l}\text { New tree. Stacked } \\
\text { townhome. }\end{array}$ \\
\hline $\begin{array}{l}\text { White } \\
\text { Spruce }\end{array}$ & Picea glauca & good condition & 0 & $\begin{array}{l}43.659829^{\circ}, \\
-79.452233^{\circ}\end{array}$ & $\begin{array}{l}\text { In front of } \\
\text { housing }\end{array}$ & $\begin{array}{l}\text { New tree. Stacked } \\
\text { townhome. }\end{array}$ \\
\hline $\begin{array}{l}\text { White } \\
\text { Spruce }\end{array}$ & Picea glauca & good condition & 0 & $\begin{array}{l}43.659838^{\circ}, \\
-79.452258^{\circ}\end{array}$ & $\begin{array}{l}\text { In front of } \\
\text { housing }\end{array}$ & $\begin{array}{l}\text { New tree. Stacked } \\
\text { townhome. }\end{array}$ \\
\hline $\begin{array}{l}\text { White } \\
\text { Spruce }\end{array}$ & Picea glauca & good condition & 0 & $\begin{array}{l}43.659850^{\circ}, \\
-79.452300^{\circ}\end{array}$ & $\begin{array}{l}\text { In front of } \\
\text { housing }\end{array}$ & $\begin{array}{l}\text { New tree. Stacked } \\
\text { townhome. }\end{array}$ \\
\hline $\begin{array}{l}\text { White } \\
\text { Spruce }\end{array}$ & Picea glauca & good condition & 0 & $\begin{array}{l}43.659872^{\circ}, \\
-79.452343^{\circ}\end{array}$ & $\begin{array}{l}\text { In front of } \\
\text { housing }\end{array}$ & $\begin{array}{l}\text { New tree. Stacked } \\
\text { townhome. }\end{array}$ \\
\hline $\begin{array}{l}\text { White } \\
\text { Spruce }\end{array}$ & Picea glauca & good condition & 0 & $\begin{array}{l}43.659877^{\circ}, \\
-79.452305^{\circ}\end{array}$ & $\begin{array}{l}\text { In front of } \\
\text { housing }\end{array}$ & $\begin{array}{l}\text { New tree. Stacked } \\
\text { townhome. }\end{array}$ \\
\hline $\begin{array}{l}\text { White } \\
\text { Spruce }\end{array}$ & Picea glauca & good condition & 0 & $\begin{array}{l}43.659928^{\circ}, \\
-79.452412^{\circ}\end{array}$ & $\begin{array}{l}\text { In front of } \\
\text { housing }\end{array}$ & $\begin{array}{l}\text { New tree. Stacked } \\
\text { townhome. }\end{array}$ \\
\hline $\begin{array}{l}\text { White } \\
\text { Spruce }\end{array}$ & Picea glauca & tree lean & 1 & $\begin{array}{l}43.659940^{\circ}, \\
-79.452390^{\circ}\end{array}$ & $\begin{array}{l}\text { In front of } \\
\text { housing }\end{array}$ & $\begin{array}{l}\text { New tree. Stacked } \\
\text { townhome. }\end{array}$ \\
\hline Chinese Elm & $\begin{array}{l}\text { Ulmus } \\
\text { parvifolia }\end{array}$ & tree lean, cracks on trunk & 2 & $\begin{array}{l}43.658582^{\circ}, \\
-79.446743^{\circ}\end{array}$ & $\begin{array}{l}\text { Public } \\
\text { (Boulevard) }\end{array}$ & \\
\hline $\begin{array}{l}\text { European } \\
\text { Beech }\end{array}$ & Fagus sylvatica & tree lean, cracks on trunk & 2 & $\begin{array}{l}43.660106^{\circ}, \\
-79.451907^{\circ} \\
\end{array}$ & $\begin{array}{l}\text { Public } \\
\text { (Boulevard) }\end{array}$ & New tree. \\
\hline $\begin{array}{l}\text { European } \\
\text { Beech }\end{array}$ & Fagus sylvatica & tree lean, cracks on trunk & 2 & $\begin{array}{l}43.660131^{\circ}, \\
-79.451792^{\circ}\end{array}$ & $\begin{array}{l}\text { Public } \\
\text { (Boulevard) }\end{array}$ & New tree. \\
\hline $\begin{array}{l}\text { European } \\
\text { Beech }\end{array}$ & Fagus sylvatica & $\begin{array}{l}10 \% \text { dieback, cracks on } \\
\text { trunk }\end{array}$ & 2 & $\begin{array}{l}43.660140^{\circ}, \\
-79.451755^{\circ}\end{array}$ & $\begin{array}{l}\text { Public } \\
\text { (Boulevard) }\end{array}$ & New tree. \\
\hline $\begin{array}{l}\text { European } \\
\text { Beech }\end{array}$ & Fagus sylvatica & $\begin{array}{l}70 \% \text { dieback, cracks on } \\
\text { trunk }\end{array}$ & 3 & $\begin{array}{l}43.660282^{\circ}, \\
-79.451423^{\circ}\end{array}$ & $\begin{array}{l}\text { Public } \\
\text { (Boulevard) }\end{array}$ & New tree. \\
\hline
\end{tabular}




\begin{tabular}{|c|c|c|c|c|c|c|}
\hline $\begin{array}{l}\text { European } \\
\text { Beech }\end{array}$ & Fagus sylvatica & defoliation & 1 & $\begin{array}{l}43.660306^{\circ} \\
-79.451503^{\circ}\end{array}$ & $\begin{array}{l}\text { Public } \\
\text { (Boulevard) }\end{array}$ & New tree. \\
\hline $\begin{array}{l}\text { European } \\
\text { Beech }\end{array}$ & Fagus sylvatica & defoliation & 1 & $\begin{array}{l}43.660322^{\circ} \\
-79.451441^{\circ}\end{array}$ & $\begin{array}{l}\text { Public } \\
\text { (Boulevard) }\end{array}$ & New tree. \\
\hline Ginkgo & Ginkgo biloba & tree lean & 1 & $\begin{array}{l}43.659837^{\circ}, \\
-79.451956^{\circ}\end{array}$ & $\begin{array}{l}\text { Public } \\
\text { (Boulevard) }\end{array}$ & New tree. \\
\hline Ginkgo & Ginkgo biloba & tree lean & 1 & $\begin{array}{l}43.659963^{\circ} \\
-79.451508^{\circ}\end{array}$ & $\begin{array}{l}\text { Public } \\
\text { (Boulevard) }\end{array}$ & New tree. \\
\hline Ginkgo & Ginkgo biloba & peeling bark & 1 & $\begin{array}{l}43.660290^{\circ} \\
-79.451625^{\circ}\end{array}$ & $\begin{array}{l}\text { Public } \\
\text { (Boulevard) }\end{array}$ & New tree. \\
\hline Green Ash & $\begin{array}{l}\text { Fraxinus } \\
\text { pennsylvanica }\end{array}$ & $\begin{array}{l}\text { tree lean, cracks and } \\
\text { cankers on trunk }\end{array}$ & 2 & $\begin{array}{l}43.658245^{\circ} \\
-79.447696^{\circ}\end{array}$ & $\begin{array}{l}\text { Public } \\
\text { (Boulevard) }\end{array}$ & \\
\hline Green Ash & $\begin{array}{l}\text { Fraxinus } \\
\text { pennsylvanica }\end{array}$ & tree lean, $20 \%$ dieback & 2 & $\begin{array}{l}43.658266^{\circ}, \\
-79.447830^{\circ}\end{array}$ & $\begin{array}{l}\text { Public } \\
\text { (Boulevard) }\end{array}$ & \\
\hline Green Ash & $\begin{array}{l}\text { Fraxinus } \\
\text { pennsylvanica }\end{array}$ & weak branch unions & 1 & $\begin{array}{l}43.658393^{\circ} \\
-79.447307^{\circ}\end{array}$ & $\begin{array}{l}\text { Public } \\
\text { (Boulevard) }\end{array}$ & \\
\hline Green Ash & $\begin{array}{l}\text { Fraxinus } \\
\text { pennsylvanica }\end{array}$ & $\begin{array}{l}\text { tree lean, cracks and } \\
\text { cankers on trunk }\end{array}$ & 2 & $\begin{array}{l}43.658451^{\circ} \\
-79.446978^{\circ}\end{array}$ & $\begin{array}{l}\text { Public } \\
\text { (Boulevard) }\end{array}$ & \\
\hline Green Ash & $\begin{array}{l}\text { Fraxinus } \\
\text { pennsylvanica }\end{array}$ & $\begin{array}{l}\text { tree lean, cracks and } \\
\text { cankers on trunk }\end{array}$ & 2 & $\begin{array}{l}43.658457^{\circ}, \\
-79.446895^{\circ}\end{array}$ & $\begin{array}{l}\text { Public } \\
\text { (Boulevard) }\end{array}$ & \\
\hline $\begin{array}{l}\text { Honey } \\
\text { Locust }\end{array}$ & $\begin{array}{l}\text { Gleditsia } \\
\text { triacanthos }\end{array}$ & $\begin{array}{l}\text { tree lean, defoliation, some } \\
\text { dead branches }\end{array}$ & 3 & $\begin{array}{l}43.659233^{\circ} \\
-79.450901^{\circ}\end{array}$ & $\begin{array}{l}\text { Public } \\
\text { (Boulevard) }\end{array}$ & $\begin{array}{l}\text { Near scrapyard/train line. } \\
\text { Construction nearby. }\end{array}$ \\
\hline $\begin{array}{l}\text { Honey } \\
\text { Locust }\end{array}$ & $\begin{array}{l}\text { Gleditsia } \\
\text { triacanthos }\end{array}$ & good condition & 0 & $\begin{array}{l}43.660619^{\circ}, \\
-79.451769^{\circ}\end{array}$ & $\begin{array}{l}\text { Public } \\
\text { (Boulevard) }\end{array}$ & New tree. \\
\hline $\begin{array}{l}\text { Honey } \\
\text { Locust }\end{array}$ & $\begin{array}{l}\text { Gleditsia } \\
\text { triacanthos }\end{array}$ & good condition & 0 & $\begin{array}{l}43.659894^{\circ}, \\
-79.451586^{\circ}\end{array}$ & $\begin{array}{l}\text { Public } \\
\text { (Boulevard) }\end{array}$ & \\
\hline $\begin{array}{l}\text { Kentucky } \\
\text { Coffeetree }\end{array}$ & $\begin{array}{l}\text { Gymnocladus } \\
\text { dioicus }\end{array}$ & good condition & 0 & $\begin{array}{l}43.659231^{\circ}, \\
-79.451044^{\circ}\end{array}$ & $\begin{array}{l}\text { Public } \\
\text { (Boulevard) }\end{array}$ & $\begin{array}{l}\text { New tree. Near } \\
\text { scrapyard/train line. } \\
\text { Construction nearby. }\end{array}$ \\
\hline $\begin{array}{l}\text { Kentucky } \\
\text { Coffeetree }\end{array}$ & $\begin{array}{l}\text { Gymnocladus } \\
\text { dioicus }\end{array}$ & good condition & 0 & $\begin{array}{l}43.659384^{\circ}, \\
-79.450324^{\circ}\end{array}$ & $\begin{array}{l}\text { Public } \\
\text { (Boulevard) }\end{array}$ & $\begin{array}{l}\text { New tree. Near } \\
\text { scrapyard/train line. } \\
\text { Construction nearby. }\end{array}$ \\
\hline $\begin{array}{l}\text { Kentucky } \\
\text { Coffeetree }\end{array}$ & $\begin{array}{l}\text { Gymnocladus } \\
\text { dioicus }\end{array}$ & good condition & 0 & $\begin{array}{l}43.659389^{\circ}, \\
-79.450537^{\circ}\end{array}$ & $\begin{array}{l}\text { Public } \\
\text { (Boulevard) }\end{array}$ & $\begin{array}{l}\text { New tree. Near } \\
\text { scrapyard/train line. } \\
\text { Construction nearby. }\end{array}$ \\
\hline $\begin{array}{l}\text { Little Leaf } \\
\text { Linden }\end{array}$ & Tilla cordata & cracks on trunk & 1 & $\begin{array}{l}43.660039^{\circ}, \\
-79.451529^{\circ}\end{array}$ & $\begin{array}{l}\text { Public } \\
\text { (Boulevard) }\end{array}$ & New tree. \\
\hline $\begin{array}{l}\text { Little Leaf } \\
\text { Linden }\end{array}$ & Tilla cordata & tree lean & 1 & $\begin{array}{l}43.660198^{\circ}, \\
-79.451542^{\circ}\end{array}$ & $\begin{array}{l}\text { Public } \\
\text { (Boulevard) }\end{array}$ & New tree. \\
\hline $\begin{array}{l}\text { Little Leaf } \\
\text { Linden }\end{array}$ & Tilla cordata & tree lean & 1 & $\begin{array}{l}43.660210^{\circ}, \\
-79.451481^{\circ}\end{array}$ & $\begin{array}{l}\text { Public } \\
\text { (Boulevard) }\end{array}$ & New tree. \\
\hline $\begin{array}{l}\text { Little Leaf } \\
\text { Linden }\end{array}$ & Tilla cordata & good condition & 0 & $\begin{array}{l}43.660234^{\circ}, \\
-79.451615^{\circ}\end{array}$ & $\begin{array}{l}\text { Public } \\
\text { (Boulevard) }\end{array}$ & New tree. \\
\hline $\begin{array}{l}\text { Little Leaf } \\
\text { Linden }\end{array}$ & Tilla cordata & tree lean, cracks on trunk & 2 & $\begin{array}{l}43.660238^{\circ}, \\
-79.451398^{\circ}\end{array}$ & $\begin{array}{l}\text { Public } \\
\text { (Boulevard) }\end{array}$ & New tree. \\
\hline $\begin{array}{l}\text { Manitoba } \\
\text { Maple }\end{array}$ & Acer negundo & $\begin{array}{l}\text { defoliation, weak branch } \\
\text { unions, cracks along trunk, } \\
\text { mildew on leaves }\end{array}$ & 3 & $\begin{array}{l}43.659207^{\circ}, \\
-79.451787^{\circ}\end{array}$ & $\begin{array}{l}\text { Public } \\
\text { (Boulevard) }\end{array}$ & $\begin{array}{l}\text { Near scrapyard/train line. } \\
\text { Construction nearby. }\end{array}$ \\
\hline $\begin{array}{l}\text { Manitoba } \\
\text { Maple }\end{array}$ & Acer negundo & $\begin{array}{l}30 \% \text { dieback, defoliation, } \\
\text { cracks on trunk }\end{array}$ & 3 & $\begin{array}{l}43.659215^{\circ}, \\
-79.451741^{\circ}\end{array}$ & $\begin{array}{l}\text { Public } \\
\text { (Boulevard) }\end{array}$ & $\begin{array}{l}\text { Near scrapyard/train line. } \\
\text { Construction nearby. }\end{array}$ \\
\hline $\begin{array}{l}\text { Manitoba } \\
\text { Maple }\end{array}$ & Acer negundo & $\begin{array}{l}30 \% \text { dieback, peeling bark, } \\
\text { mildew on leaves }\end{array}$ & 3 & $\begin{array}{l}43.659222^{\circ} \\
-79.451687^{\circ}\end{array}$ & $\begin{array}{l}\text { Public } \\
\text { (Boulevard) }\end{array}$ & $\begin{array}{l}\text { Near scrapyard/train line. } \\
\text { Construction nearby. }\end{array}$ \\
\hline $\begin{array}{l}\text { Manitoba } \\
\text { Maple }\end{array}$ & Acer negundo & $\begin{array}{l}\text { defoliation, weak branch } \\
\text { unions, cracks on trunk, } \\
\text { mildew on leaves }\end{array}$ & 3 & $\begin{array}{l}43.659410^{\circ}, \\
-79.450819^{\circ}\end{array}$ & $\begin{array}{l}\text { Public } \\
\text { (Boulevard) }\end{array}$ & $\begin{array}{l}\text { Near scrapyard/train line. } \\
\text { Construction nearby. }\end{array}$ \\
\hline $\begin{array}{l}\text { Manitoba } \\
\text { Maple }\end{array}$ & Acer negundo & $\begin{array}{l}20 \% \text { dieback, dead/broken } \\
\text { branches, cracks along } \\
\text { trunk, mildew on leaves }\end{array}$ & 3 & $\begin{array}{l}43.659422^{\circ}, \\
-79.450770^{\circ}\end{array}$ & $\begin{array}{l}\text { Public } \\
\text { (Boulevard) }\end{array}$ & $\begin{array}{l}\text { Near scrapyard/train line. } \\
\text { Construction nearby. }\end{array}$ \\
\hline $\begin{array}{l}\text { Manitoba } \\
\text { Maple }\end{array}$ & Acer negundo & tree lean, $20 \%$ dieback & 2 & $\begin{array}{l}43.658357^{\circ}, \\
-79.447470^{\circ}\end{array}$ & $\begin{array}{l}\text { Public } \\
\text { (Boulevard) }\end{array}$ & \\
\hline $\begin{array}{l}\text { Manitoba } \\
\text { Maple }\end{array}$ & Acer negundo & $\begin{array}{l}\text { tree lean, } 30 \% \text { dieback, } \\
\text { major cracks on trunk }\end{array}$ & 3 & $\begin{array}{l}43.658391^{\circ} \\
-79.447343^{\circ}\end{array}$ & $\begin{array}{l}\text { Public } \\
\text { (Boulevard) }\end{array}$ & \\
\hline $\begin{array}{l}\text { Norway } \\
\text { Maple }\end{array}$ & $\begin{array}{l}\text { Acer } \\
\text { platanoides }\end{array}$ & $\begin{array}{l}\text { tree lean, defoliation, } \\
\text { dead/broken branches }\end{array}$ & 3 & $\begin{array}{l}43.657287^{\circ}, \\
-79.448168^{\circ}\end{array}$ & $\begin{array}{l}\text { Public } \\
\text { (Boulevard) }\end{array}$ & \\
\hline $\begin{array}{l}\text { Norway } \\
\text { Maple }\end{array}$ & $\begin{array}{l}\text { Acer } \\
\text { platanoides }\end{array}$ & peeling bark & 1 & $\begin{array}{l}43.658116^{\circ}, \\
-79.447795^{\circ}\end{array}$ & $\begin{array}{l}\text { Public } \\
\text { (Boulevard) }\end{array}$ & \\
\hline $\begin{array}{l}\text { Norway } \\
\text { Maple }\end{array}$ & $\begin{array}{l}\text { Acer } \\
\text { platanoides }\end{array}$ & good condition & 0 & $\begin{array}{l}43.658228^{\circ}, \\
-79.447864^{\circ}\end{array}$ & $\begin{array}{l}\text { Public } \\
\text { (Boulevard) }\end{array}$ & \\
\hline
\end{tabular}




\begin{tabular}{|c|c|c|c|c|c|c|}
\hline $\begin{array}{l}\text { Norway } \\
\text { Maple }\end{array}$ & $\begin{array}{l}\text { Acer } \\
\text { platanoides }\end{array}$ & tree lean & 1 & $\begin{array}{l}43.658574^{\circ} \\
-79.446484^{\circ}\end{array}$ & $\begin{array}{l}\text { Public } \\
\text { (Boulevard) }\end{array}$ & \\
\hline $\begin{array}{l}\text { Norway } \\
\text { Maple }\end{array}$ & $\begin{array}{l}\text { Acer } \\
\text { platanoides }\end{array}$ & good condition & 0 & $\begin{array}{l}43.658596^{\circ} \\
-79.446373^{\circ}\end{array}$ & $\begin{array}{l}\text { Public } \\
\text { (Boulevard) }\end{array}$ & \\
\hline $\begin{array}{l}\text { Ohio } \\
\text { Buckeye }\end{array}$ & $\begin{array}{l}\text { Aesculus } \\
\text { glabra }\end{array}$ & $\begin{array}{l}\text { discoloured leaves, peeling } \\
\text { bark }\end{array}$ & 2 & $\begin{array}{l}43.659296^{\circ} \\
-79.450745^{\circ}\end{array}$ & $\begin{array}{l}\text { Public } \\
\text { (Boulevard) }\end{array}$ & $\begin{array}{l}\text { New tree. Near } \\
\text { scrapyard/train line. } \\
\text { Construction nearby. }\end{array}$ \\
\hline Red Oak & Quercus rubra & good condition & 0 & $\begin{array}{l}43.660584^{\circ}, \\
-79.452360^{\circ}\end{array}$ & $\begin{array}{l}\text { Public } \\
\text { (Boulevard) }\end{array}$ & \\
\hline Red Oak & Quercus rubra & good condition & 0 & $\begin{array}{l}43.660610^{\circ}, \\
-79.452214^{\circ}\end{array}$ & $\begin{array}{l}\text { Public } \\
\text { (Boulevard) }\end{array}$ & \\
\hline Redbud & $\begin{array}{l}\text { Cercis } \\
\text { canadensis }\end{array}$ & good condition & 0 & $\begin{array}{l}43.657471^{\circ} \\
-79.447690^{\circ}\end{array}$ & $\begin{array}{l}\text { Public } \\
\text { (Boulevard) }\end{array}$ & \\
\hline $\begin{array}{l}\text { Siberian } \\
\text { Elm }\end{array}$ & Ulmus pumila & $\begin{array}{l}50 \% \text { dieback, dead/broken } \\
\text { branches }\end{array}$ & 3 & $\begin{array}{l}43.659906^{\circ} \\
-79.451081^{\circ}\end{array}$ & $\begin{array}{l}\text { Public } \\
\text { (Boulevard) }\end{array}$ & $\begin{array}{l}\text { Near construction \& } \\
\text { scrapyard. }\end{array}$ \\
\hline $\begin{array}{l}\text { Silver } \\
\text { Maple }\end{array}$ & $\begin{array}{l}\text { Acer } \\
\text { saccharinum }\end{array}$ & $\begin{array}{l}\text { tree lean, cracks and } \\
\text { cankers on trunk }\end{array}$ & 2 & $\begin{array}{l}43.658396^{\circ}, \\
-79.447300^{\circ}\end{array}$ & $\begin{array}{l}\text { Public } \\
\text { (Boulevard) }\end{array}$ & \\
\hline $\begin{array}{l}\text { Tree of } \\
\text { Heaven }\end{array}$ & $\begin{array}{l}\text { Ailanthus } \\
\text { altissima }\end{array}$ & tree lean & 1 & $\begin{array}{l}43.657246^{\circ}, \\
-79.448396^{\circ}\end{array}$ & $\begin{array}{l}\text { Public } \\
\text { (Boulevard) }\end{array}$ & New tree. \\
\hline $\begin{array}{l}\text { Tree of } \\
\text { Heaven }\end{array}$ & $\begin{array}{l}\text { Ailanthus } \\
\text { altissima }\end{array}$ & good condition & 0 & $\begin{array}{l}43.658288^{\circ} \\
-79.447888^{\circ}\end{array}$ & $\begin{array}{l}\text { Public } \\
\text { (Boulevard) }\end{array}$ & New tree. \\
\hline $\begin{array}{l}\text { Tree of } \\
\text { Heaven }\end{array}$ & $\begin{array}{l}\text { Ailanthus } \\
\text { altissima }\end{array}$ & tree lean & 1 & $\begin{array}{l}43.659533^{\circ} \\
-79.450481^{\circ}\end{array}$ & $\begin{array}{l}\text { Public } \\
\text { (Boulevard) }\end{array}$ & New tree. \\
\hline $\begin{array}{l}\text { Tree of } \\
\text { Heaven }\end{array}$ & $\begin{array}{l}\text { Ailanthus } \\
\text { altissima }\end{array}$ & $60 \%$ dieback, tree lean & 3 & $\begin{array}{l}43.659863^{\circ} \\
-79.451382^{\circ}\end{array}$ & $\begin{array}{l}\text { Public } \\
\text { (Boulevard) }\end{array}$ & $\begin{array}{l}\text { New tree. Near construction } \\
\& \text { scrapyard. }\end{array}$ \\
\hline $\begin{array}{l}\text { Tree of } \\
\text { Heaven }\end{array}$ & $\begin{array}{l}\text { Ailanthus } \\
\text { altissima }\end{array}$ & tree lean & 2 & $\begin{array}{l}43.659887^{\circ}, \\
-79.451252^{\circ}\end{array}$ & $\begin{array}{l}\text { Public } \\
\text { (Boulevard) }\end{array}$ & $\begin{array}{l}\text { New tree. Near construction } \\
\& \text { scrapyard. }\end{array}$ \\
\hline $\begin{array}{l}\text { Tree of } \\
\text { Heaven }\end{array}$ & $\begin{array}{l}\text { Ailanthus } \\
\text { altissima }\end{array}$ & $60 \%$ dieback, tree lean & 3 & $\begin{array}{l}43.659906^{\circ}, \\
-79.451152^{\circ}\end{array}$ & $\begin{array}{l}\text { Public } \\
\text { (Boulevard) }\end{array}$ & $\begin{array}{l}\text { New tree. Near construction } \\
\& \text { scrapyard. }\end{array}$ \\
\hline $\begin{array}{l}\text { Tree of } \\
\text { Heaven }\end{array}$ & $\begin{array}{l}\text { Ailanthus } \\
\text { altissima }\end{array}$ & DEAD & 4 & $\begin{array}{l}43.659928^{\circ} \\
-79.451007^{\circ}\end{array}$ & $\begin{array}{l}\text { Public } \\
\text { (Boulevard) }\end{array}$ & $\begin{array}{l}\text { New tree. Near construction } \\
\& \text { scrapyard. }\end{array}$ \\
\hline $\begin{array}{l}\text { Tree of } \\
\text { Heaven }\end{array}$ & $\begin{array}{l}\text { Ailanthus } \\
\text { altissima }\end{array}$ & tree lean & 1 & $\begin{array}{l}43.659088^{\circ} \\
-79.451560^{\circ}\end{array}$ & $\begin{array}{l}\text { Public } \\
\text { (Boulevard) }\end{array}$ & $\begin{array}{l}\text { New tree. Near } \\
\text { scrapyard/train line. } \\
\text { Construction nearby. }\end{array}$ \\
\hline $\begin{array}{l}\text { Black } \\
\text { Locust }\end{array}$ & $\begin{array}{l}\text { Robinia } \\
\text { pseudoacacia }\end{array}$ & $\begin{array}{l}\text { tree lean, cankers on trunk, } \\
\text { dead/broken branches, } \\
\text { weak branch unions }\end{array}$ & 3 & $\begin{array}{l}43.659010^{\circ}, \\
-79.446096^{\circ}\end{array}$ & Public (Park) & \\
\hline $\begin{array}{l}\text { Black } \\
\text { Locust }\end{array}$ & $\begin{array}{l}\text { Robinia } \\
\text { pseudoacacia }\end{array}$ & dead/broken branches & 1 & $\begin{array}{l}43.659040^{\circ}, \\
-79.446010^{\circ}\end{array}$ & Public (Park) & \\
\hline $\begin{array}{l}\text { Black } \\
\text { Locust }\end{array}$ & $\begin{array}{l}\text { Robinia } \\
\text { pseudoacacia }\end{array}$ & dead/broken branches & 1 & $\begin{array}{l}43.659061^{\circ} \\
-79.445995^{\circ}\end{array}$ & Public (Park) & \\
\hline $\begin{array}{l}\text { Black } \\
\text { Locust }\end{array}$ & $\begin{array}{l}\text { Robinia } \\
\text { pseudoacacia }\end{array}$ & $\begin{array}{l}\text { weak branch unions, } 20 \% \\
\text { dieback }\end{array}$ & 2 & $\begin{array}{l}43.659703^{\circ} \\
-79.446477^{\circ}\end{array}$ & Public (Park) & \\
\hline Black Maple & Acer nigrum & $\begin{array}{l}\text { tree lean, cracks and } \\
\text { cankers on trunk }\end{array}$ & 3 & $\begin{array}{l}43.659478^{\circ} \\
-79.446023^{\circ}\end{array}$ & Public (Park) & \\
\hline Black Maple & Acer nigrum & $\begin{array}{l}\text { tree lean, cracks and } \\
\text { cankers on trunk }\end{array}$ & 3 & $\begin{array}{l}43.659539^{\circ}, \\
-79.446059^{\circ}\end{array}$ & Public (Park) & \\
\hline Black Maple & Acer nigrum & $\begin{array}{l}\text { large cracks and cankers on } \\
\text { trunk }\end{array}$ & 3 & $\begin{array}{l}43.659561^{\circ} \\
-79.446439^{\circ}\end{array}$ & Public (Park) & \\
\hline Black Maple & Acer nigrum & cankers on trunk & 1 & $\begin{array}{l}43.659579^{\circ} \\
-79.446231^{\circ}\end{array}$ & Public (Park) & \\
\hline Black Maple & Acer nigrum & cracks on trunk & 1 & $\begin{array}{l}43.659612^{\circ}, \\
-79.446442^{\circ}\end{array}$ & Public (Park) & \\
\hline Black Maple & Acer nigrum & tree lean, cracks on trunk & 1 & $\begin{array}{l}43.659670^{\circ}, \\
-79.446479^{\circ}\end{array}$ & Public (Park) & \\
\hline Black Maple & Acer nigrum & cracks on trunk & 2 & $\begin{array}{l}43.659931^{\circ} \\
-79.446413^{\circ}\end{array}$ & Public (Park) & \\
\hline Chinese Elm & $\begin{array}{l}\text { Ulmus } \\
\text { parvifolia }\end{array}$ & tree lean, defoliation & 2 & $\begin{array}{l}43.659922^{\circ}, \\
-79.446456^{\circ}\end{array}$ & Public (Park) & \\
\hline $\begin{array}{l}\text { Choke } \\
\text { Cherry }\end{array}$ & $\begin{array}{l}\text { Prunus } \\
\text { virginiana }\end{array}$ & tree lean & 1 & $\begin{array}{l}43.658672^{\circ}, \\
-79.449900^{\circ}\end{array}$ & Public (Park) & \\
\hline $\begin{array}{l}\text { Choke } \\
\text { Cherry }\end{array}$ & $\begin{array}{l}\text { Prunus } \\
\text { virginiana }\end{array}$ & tree lean, defoliation & 2 & $\begin{array}{l}43.658698^{\circ}, \\
-79.449870^{\circ}\end{array}$ & Public (Park) & \\
\hline $\begin{array}{l}\text { Choke } \\
\text { Cherry }\end{array}$ & $\begin{array}{l}\text { Prunus } \\
\text { virginiana }\end{array}$ & tree lean & 1 & $\begin{array}{l}43.658708^{\circ}, \\
-79.449817^{\circ}\end{array}$ & Public (Park) & \\
\hline Douglas Fir & $\begin{array}{l}\text { Pseudotsuga } \\
\text { menziesii }\end{array}$ & discoloured leaves & 1 & $\begin{array}{l}43.658737^{\circ}, \\
-79.450197^{\circ}\end{array}$ & Public (Park) & \\
\hline
\end{tabular}




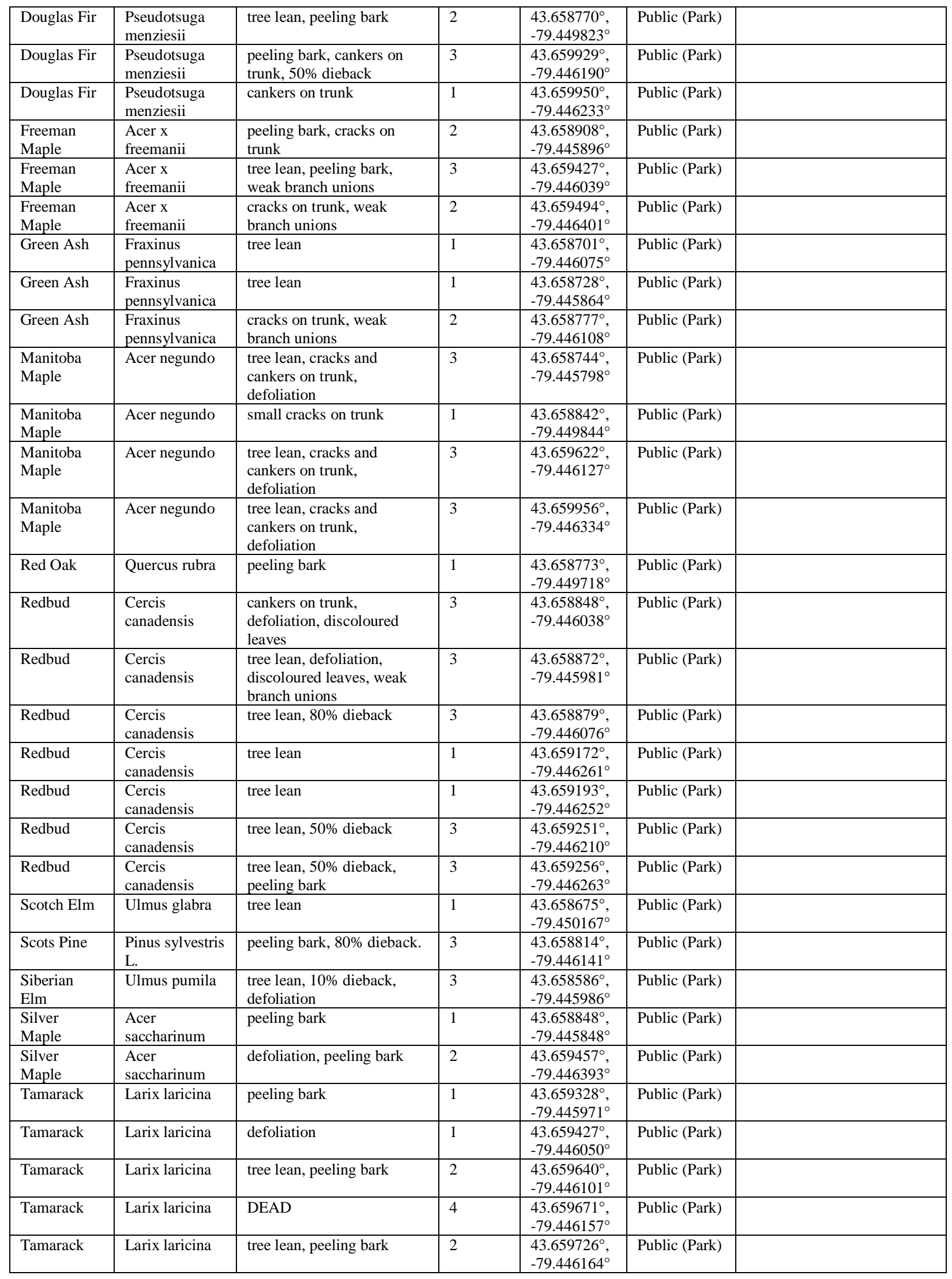




\begin{tabular}{|c|c|c|c|c|c|c|}
\hline Tamarack & Larix laricina & $\begin{array}{l}\text { tree lean, peeling bark, } 50 \% \\
\text { dieback }\end{array}$ & 3 & $\begin{array}{l}43.659764^{\circ}, \\
-79.446190^{\circ}\end{array}$ & Public (Park) & \\
\hline Tamarack & Larix laricina & cracks on trunk, defoliation & 2 & $\begin{array}{l}43.659954^{\circ}, \\
-79.446367^{\circ}\end{array}$ & Public (Park) & \\
\hline $\begin{array}{l}\text { Trembling } \\
\text { Aspen }\end{array}$ & $\begin{array}{l}\text { Populus } \\
\text { tremuloides }\end{array}$ & $\begin{array}{l}\text { tree lean, dead/broken } \\
\text { branches, weak branch } \\
\text { unions }\end{array}$ & 3 & $\begin{array}{l}43.658727^{\circ}, \\
-79.445831^{\circ}\end{array}$ & Public (Park) & \\
\hline $\begin{array}{l}\text { Trembling } \\
\text { Aspen }\end{array}$ & $\begin{array}{l}\text { Populus } \\
\text { tremuloides }\end{array}$ & $\begin{array}{l}\text { tree lean, dead/broken } \\
\text { branches }\end{array}$ & 2 & $\begin{array}{l}43.658735^{\circ}, \\
-79.445777^{\circ}\end{array}$ & Public (Park) & \\
\hline $\begin{array}{l}\text { Trembling } \\
\text { Aspen }\end{array}$ & $\begin{array}{l}\text { Populus } \\
\text { tremuloides }\end{array}$ & DEAD & 4 & $\begin{array}{l}43.658843^{\circ} \\
-79.445792^{\circ}\end{array}$ & Public (Park) & \\
\hline $\begin{array}{l}\text { Trembling } \\
\text { Aspen }\end{array}$ & $\begin{array}{l}\text { Populus } \\
\text { tremuloides }\end{array}$ & $\begin{array}{l}\text { tree lean, dead/broken } \\
\text { branches }\end{array}$ & 2 & $\begin{array}{l}43.659035^{\circ}, \\
-79.445885^{\circ}\end{array}$ & Public (Park) & \\
\hline $\begin{array}{l}\text { Trembling } \\
\text { Aspen }\end{array}$ & $\begin{array}{l}\text { Populus } \\
\text { tremuloides }\end{array}$ & $\begin{array}{l}\text { tree lean, dead/broken } \\
\text { branches }\end{array}$ & 2 & $\begin{array}{l}43.659161^{\circ}, \\
-79.445918^{\circ}\end{array}$ & Public (Park) & \\
\hline $\begin{array}{l}\text { Trembling } \\
\text { Aspen }\end{array}$ & $\begin{array}{l}\text { Populus } \\
\text { tremuloides }\end{array}$ & $\begin{array}{l}\text { tree lean, dead/broken } \\
\text { branches }\end{array}$ & 3 & $\begin{array}{l}43.659259^{\circ}, \\
-79.445949^{\circ}\end{array}$ & Public (Park) & \\
\hline $\begin{array}{l}\text { Trembling } \\
\text { Aspen }\end{array}$ & $\begin{array}{l}\text { Populus } \\
\text { tremuloides }\end{array}$ & tree lean & 1 & $\begin{array}{l}43.659538^{\circ}, \\
-79.446061^{\circ} \\
\end{array}$ & Public (Park) & \\
\hline $\begin{array}{l}\text { Trembling } \\
\text { Aspen }\end{array}$ & $\begin{array}{l}\text { Populus } \\
\text { tremuloides }\end{array}$ & $\begin{array}{l}\text { tree lean, cracks and } \\
\text { cankers on trunk, } 20 \% \\
\text { dieback }\end{array}$ & 3 & $\begin{array}{l}43.659984^{\circ}, \\
-79.446296^{\circ}\end{array}$ & Public (Park) & \\
\hline $\begin{array}{l}\text { American } \\
\text { Elm }\end{array}$ & $\begin{array}{l}\text { Ulmus } \\
\text { americana }\end{array}$ & tree lean, defoliation & 2 & $\begin{array}{l}43.658923^{\circ}, \\
-79.451566^{\circ}\end{array}$ & $\begin{array}{l}\text { Public (West } \\
\text { Toronto } \\
\text { Railpath) }\end{array}$ & New tree. \\
\hline $\begin{array}{l}\text { American } \\
\text { Elm }\end{array}$ & $\begin{array}{l}\text { Ulmus } \\
\text { americana }\end{array}$ & tree lean, defoliation & 2 & $\begin{array}{l}43.658931^{\circ}, \\
-79.451549^{\circ}\end{array}$ & $\begin{array}{l}\text { Public (West } \\
\text { Toronto } \\
\text { Railpath) } \\
\end{array}$ & New tree. \\
\hline $\begin{array}{l}\text { American } \\
\text { Elm }\end{array}$ & $\begin{array}{l}\text { Ulmus } \\
\text { americana }\end{array}$ & good condition & 0 & $\begin{array}{l}43.657057^{\circ} \\
-79.449816^{\circ}\end{array}$ & $\begin{array}{l}\text { Public (West } \\
\text { Toronto } \\
\text { Railpath) } \\
\end{array}$ & New tree. \\
\hline $\begin{array}{l}\text { American } \\
\text { Elm }\end{array}$ & $\begin{array}{l}\text { Ulmus } \\
\text { americana }\end{array}$ & good condition & 0 & $\begin{array}{l}43.657086^{\circ}, \\
-79.449839^{\circ}\end{array}$ & $\begin{array}{l}\text { Public (West } \\
\text { Toronto } \\
\text { Railpath) }\end{array}$ & New tree. \\
\hline $\begin{array}{l}\text { American } \\
\text { Elm }\end{array}$ & $\begin{array}{l}\text { Ulmus } \\
\text { americana }\end{array}$ & good condition & 0 & $\begin{array}{l}43.657117^{\circ}, \\
-79.449757^{\circ}\end{array}$ & $\begin{array}{l}\text { Public (West } \\
\text { Toronto } \\
\text { Railpath) }\end{array}$ & New tree. \\
\hline $\begin{array}{l}\text { American } \\
\text { Elm }\end{array}$ & $\begin{array}{l}\text { Ulmus } \\
\text { americana }\end{array}$ & good condition & 0 & $\begin{array}{l}43.657124^{\circ}, \\
-79.449791^{\circ}\end{array}$ & $\begin{array}{l}\text { Public (West } \\
\text { Toronto } \\
\text { Railpath) }\end{array}$ & New tree. \\
\hline $\begin{array}{l}\text { American } \\
\text { Elm }\end{array}$ & $\begin{array}{l}\text { Ulmus } \\
\text { americana }\end{array}$ & good condition & 0 & $\begin{array}{l}43.657239^{\circ}, \\
-79.449984^{\circ}\end{array}$ & $\begin{array}{l}\text { Public (West } \\
\text { Toronto } \\
\text { Railpath) } \\
\end{array}$ & New tree. \\
\hline $\begin{array}{l}\text { American } \\
\text { Elm }\end{array}$ & $\begin{array}{l}\text { Ulmus } \\
\text { americana }\end{array}$ & good condition & 0 & $\begin{array}{l}43.657273^{\circ} \\
-79.450015^{\circ}\end{array}$ & $\begin{array}{l}\text { Public (West } \\
\text { Toronto } \\
\text { Railpath) } \\
\end{array}$ & New tree. \\
\hline $\begin{array}{l}\text { American } \\
\text { Elm }\end{array}$ & $\begin{array}{l}\text { Ulmus } \\
\text { americana }\end{array}$ & good condition & 0 & $\begin{array}{l}43.657274^{\circ}, \\
-79.449918^{\circ}\end{array}$ & $\begin{array}{l}\text { Public (West } \\
\text { Toronto } \\
\text { Railpath) } \\
\end{array}$ & New tree. \\
\hline $\begin{array}{l}\text { American } \\
\text { Elm }\end{array}$ & $\begin{array}{l}\text { Ulmus } \\
\text { americana }\end{array}$ & good condition & 0 & $\begin{array}{l}43.657304^{\circ}, \\
-79.450047^{\circ}\end{array}$ & $\begin{array}{l}\text { Public (West } \\
\text { Toronto } \\
\text { Railpath) } \\
\end{array}$ & New tree. \\
\hline $\begin{array}{l}\text { American } \\
\text { Elm }\end{array}$ & $\begin{array}{l}\text { Ulmus } \\
\text { americana }\end{array}$ & good condition & 0 & $\begin{array}{l}43.657320^{\circ}, \\
-79.450069^{\circ}\end{array}$ & $\begin{array}{l}\text { Public (West } \\
\text { Toronto } \\
\text { Railpath) } \\
\end{array}$ & New tree. \\
\hline $\begin{array}{l}\text { American } \\
\text { Elm }\end{array}$ & $\begin{array}{l}\text { Ulmus } \\
\text { americana }\end{array}$ & good condition & 0 & $\begin{array}{l}43.657396^{\circ}, \\
-79.450056^{\circ}\end{array}$ & $\begin{array}{l}\text { Public (West } \\
\text { Toronto } \\
\text { Railpath) }\end{array}$ & New tree. \\
\hline $\begin{array}{l}\text { American } \\
\text { Elm }\end{array}$ & $\begin{array}{l}\text { Ulmus } \\
\text { americana }\end{array}$ & good condition & 0 & $\begin{array}{l}43.657481^{\circ}, \\
-79.450223^{\circ}\end{array}$ & $\begin{array}{l}\text { Public (West } \\
\text { Toronto } \\
\text { Railpath) } \\
\end{array}$ & New tree. \\
\hline $\begin{array}{l}\text { American } \\
\text { Elm }\end{array}$ & $\begin{array}{l}\text { Ulmus } \\
\text { americana }\end{array}$ & good condition & 0 & $\begin{array}{l}43.657502^{\circ}, \\
-79.450146^{\circ}\end{array}$ & $\begin{array}{l}\text { Public (West } \\
\text { Toronto } \\
\text { Railpath) }\end{array}$ & New tree. \\
\hline $\begin{array}{l}\text { American } \\
\text { Elm }\end{array}$ & $\begin{array}{l}\text { Ulmus } \\
\text { americana }\end{array}$ & good condition & 0 & $\begin{array}{l}43.657512^{\circ}, \\
-79.450258^{\circ}\end{array}$ & $\begin{array}{l}\text { Public (West } \\
\text { Toronto } \\
\text { Railpath) }\end{array}$ & New tree. \\
\hline
\end{tabular}




\begin{tabular}{|c|c|c|c|c|c|c|}
\hline $\begin{array}{l}\text { American } \\
\text { Elm }\end{array}$ & $\begin{array}{l}\text { Ulmus } \\
\text { americana }\end{array}$ & tree lean & 1 & $\begin{array}{l}43.660155^{\circ}, \\
-79.452712^{\circ}\end{array}$ & $\begin{array}{l}\text { Public (West } \\
\text { Toronto } \\
\text { Railpath) }\end{array}$ & New tree. Near construction. \\
\hline $\begin{array}{l}\text { American } \\
\text { Elm }\end{array}$ & $\begin{array}{l}\text { Ulmus } \\
\text { americana }\end{array}$ & tree lean & 1 & $\begin{array}{l}43.660198^{\circ}, \\
-79.452746^{\circ}\end{array}$ & $\begin{array}{l}\text { Public (West } \\
\text { Toronto } \\
\text { Railpath) }\end{array}$ & New tree. Near construction. \\
\hline $\begin{array}{l}\text { American } \\
\text { Elm }\end{array}$ & $\begin{array}{l}\text { Ulmus } \\
\text { americana }\end{array}$ & $\begin{array}{l}\text { tree lean, dead/broken } \\
\text { branches }\end{array}$ & 3 & $\begin{array}{l}43.660235^{\circ} \\
-79.452777^{\circ}\end{array}$ & $\begin{array}{l}\text { Public (West } \\
\text { Toronto } \\
\text { Railpath) }\end{array}$ & New tree. Near construction. \\
\hline $\begin{array}{l}\text { American } \\
\text { Elm }\end{array}$ & $\begin{array}{l}\text { Ulmus } \\
\text { americana }\end{array}$ & $\begin{array}{l}\text { tree lean, dead/broken } \\
\text { branches }\end{array}$ & 3 & $\begin{array}{l}43.660282^{\circ}, \\
-79.452813^{\circ}\end{array}$ & $\begin{array}{l}\text { Public (West } \\
\text { Toronto } \\
\text { Railpath) }\end{array}$ & New tree. Near construction. \\
\hline $\begin{array}{l}\text { American } \\
\text { Elm }\end{array}$ & $\begin{array}{l}\text { Ulmus } \\
\text { americana }\end{array}$ & cracks on trunk & 1 & $\begin{array}{l}43.660346^{\circ} \\
-79.452859^{\circ}\end{array}$ & $\begin{array}{l}\text { Public (West } \\
\text { Toronto } \\
\text { Railpath) }\end{array}$ & New tree. Near construction. \\
\hline $\begin{array}{l}\text { Black } \\
\text { Locust }\end{array}$ & $\begin{array}{l}\text { Robinia } \\
\text { pseudoacacia }\end{array}$ & good condition & 0 & $\begin{array}{l}43.657807^{\circ}, \\
-79.450489^{\circ}\end{array}$ & $\begin{array}{l}\text { Public (West } \\
\text { Toronto } \\
\text { Railpath) }\end{array}$ & New tree. \\
\hline $\begin{array}{l}\text { Black } \\
\text { Locust }\end{array}$ & $\begin{array}{l}\text { Robinia } \\
\text { pseudoacacia }\end{array}$ & good condition & 0 & $\begin{array}{l}43.657810^{\circ}, \\
-79.450470^{\circ}\end{array}$ & $\begin{array}{l}\text { Public (West } \\
\text { Toronto } \\
\text { Railpath) }\end{array}$ & New tree. \\
\hline $\begin{array}{l}\text { Black } \\
\text { Locust }\end{array}$ & $\begin{array}{l}\text { Robinia } \\
\text { pseudoacacia }\end{array}$ & good condition & 0 & $\begin{array}{l}43.657817^{\circ}, \\
-79.450480^{\circ}\end{array}$ & $\begin{array}{l}\text { Public (West } \\
\text { Toronto } \\
\text { Railpath) }\end{array}$ & New tree. \\
\hline $\begin{array}{l}\text { Black } \\
\text { Locust }\end{array}$ & $\begin{array}{l}\text { Robinia } \\
\text { pseudoacacia }\end{array}$ & good condition & 0 & $\begin{array}{l}43.657822^{\circ} \\
-79.450504^{\circ}\end{array}$ & $\begin{array}{l}\text { Public (West } \\
\text { Toronto } \\
\text { Railpath) }\end{array}$ & New tree. \\
\hline $\begin{array}{l}\text { Black } \\
\text { Locust }\end{array}$ & $\begin{array}{l}\text { Robinia } \\
\text { pseudoacacia }\end{array}$ & good condition & 0 & $\begin{array}{l}43.657833^{\circ} \\
-79.450516^{\circ}\end{array}$ & $\begin{array}{l}\text { Public (West } \\
\text { Toronto } \\
\text { Railpath) }\end{array}$ & New tree. \\
\hline $\begin{array}{l}\text { Black } \\
\text { Locust }\end{array}$ & $\begin{array}{l}\text { Robinia } \\
\text { pseudoacacia }\end{array}$ & dead/broken branches & 2 & $\begin{array}{l}43.657851^{\circ}, \\
-79.450534^{\circ}\end{array}$ & $\begin{array}{l}\text { Public (West } \\
\text { Toronto } \\
\text { Railpath) }\end{array}$ & New tree. \\
\hline $\begin{array}{l}\text { Black } \\
\text { Locust }\end{array}$ & $\begin{array}{l}\text { Robinia } \\
\text { pseudoacacia }\end{array}$ & tree lean & 1 & $\begin{array}{l}43.657857^{\circ}, \\
-79.450525^{\circ}\end{array}$ & $\begin{array}{l}\text { Public (West } \\
\text { Toronto } \\
\text { Railpath) }\end{array}$ & New tree. \\
\hline $\begin{array}{l}\text { Black } \\
\text { Locust }\end{array}$ & $\begin{array}{l}\text { Robinia } \\
\text { pseudoacacia }\end{array}$ & good condition & 0 & $\begin{array}{l}43.657941^{\circ}, \\
-79.450599^{\circ}\end{array}$ & $\begin{array}{l}\text { Public (West } \\
\text { Toronto } \\
\text { Railpath) }\end{array}$ & New tree. \\
\hline $\begin{array}{l}\text { Black } \\
\text { Locust }\end{array}$ & $\begin{array}{l}\text { Robinia } \\
\text { pseudoacacia }\end{array}$ & good condition & 0 & $\begin{array}{l}43.657985^{\circ}, \\
-79.450656^{\circ}\end{array}$ & $\begin{array}{l}\text { Public (West } \\
\text { Toronto } \\
\text { Railpath) }\end{array}$ & New tree. \\
\hline $\begin{array}{l}\text { Black } \\
\text { Locust }\end{array}$ & $\begin{array}{l}\text { Robinia } \\
\text { pseudoacacia }\end{array}$ & good condition & 0 & $\begin{array}{l}43.658014^{\circ}, \\
-79.450662^{\circ}\end{array}$ & $\begin{array}{l}\text { Public (West } \\
\text { Toronto } \\
\text { Railpath) }\end{array}$ & New tree. \\
\hline $\begin{array}{l}\text { Black } \\
\text { Locust }\end{array}$ & $\begin{array}{l}\text { Robinia } \\
\text { pseudoacacia }\end{array}$ & good condition & 0 & $\begin{array}{l}43.658091^{\circ}, \\
-79.450746^{\circ}\end{array}$ & $\begin{array}{l}\text { Public (West } \\
\text { Toronto } \\
\text { Railpath) }\end{array}$ & New tree. \\
\hline $\begin{array}{l}\text { Black } \\
\text { Locust }\end{array}$ & $\begin{array}{l}\text { Robinia } \\
\text { pseudoacacia }\end{array}$ & good condition & 0 & $\begin{array}{l}43.658133^{\circ}, \\
-79.450788^{\circ}\end{array}$ & $\begin{array}{l}\text { Public (West } \\
\text { Toronto } \\
\text { Railpath) }\end{array}$ & New tree. \\
\hline Chinese Elm & $\begin{array}{l}\text { Ulmus } \\
\text { parvifolia }\end{array}$ & good condition & 0 & $\begin{array}{l}43.657623^{\circ}, \\
-79.450293^{\circ}\end{array}$ & $\begin{array}{l}\text { Public (West } \\
\text { Toronto } \\
\text { Railpath) }\end{array}$ & New tree. \\
\hline Chinese Elm & $\begin{array}{l}\text { Ulmus } \\
\text { parvifolia }\end{array}$ & tree lean & 1 & $\begin{array}{l}43.657637^{\circ}, \\
-79.450323^{\circ}\end{array}$ & $\begin{array}{l}\text { Public (West } \\
\text { Toronto } \\
\text { Railpath) }\end{array}$ & New tree. \\
\hline Chinese Elm & $\begin{array}{l}\text { Ulmus } \\
\text { parvifolia }\end{array}$ & defoliation & 1 & $\begin{array}{l}43.657641^{\circ}, \\
-79.450323^{\circ}\end{array}$ & $\begin{array}{l}\text { Public (West } \\
\text { Toronto } \\
\text { Railpath) }\end{array}$ & New tree. \\
\hline Chinese Elm & $\begin{array}{l}\text { Ulmus } \\
\text { parvifolia }\end{array}$ & defoliation & 1 & $\begin{array}{l}43.657642^{\circ}, \\
-79.450291^{\circ}\end{array}$ & $\begin{array}{l}\text { Public (West } \\
\text { Toronto } \\
\text { Railpath) }\end{array}$ & New tree. \\
\hline Chinese Elm & $\begin{array}{l}\text { Ulmus } \\
\text { parvifolia }\end{array}$ & tree lean & 1 & $\begin{array}{l}43.657655^{\circ}, \\
-79.450300^{\circ}\end{array}$ & $\begin{array}{l}\text { Public (West } \\
\text { Toronto } \\
\text { Railpath) }\end{array}$ & New tree. \\
\hline Chinese Elm & $\begin{array}{l}\text { Ulmus } \\
\text { parvifolia }\end{array}$ & dead/broken branches & 2 & $\begin{array}{l}43.657667^{\circ}, \\
-79.450303^{\circ}\end{array}$ & $\begin{array}{l}\text { Public (West } \\
\text { Toronto } \\
\text { Railpath) } \\
\end{array}$ & New tree. \\
\hline
\end{tabular}




\begin{tabular}{|c|c|c|c|c|c|c|}
\hline Chinese Elm & $\begin{array}{l}\text { Ulmus } \\
\text { parvifolia }\end{array}$ & $\begin{array}{l}\text { cankers on trunk, tree lean, } \\
\text { defoliation }\end{array}$ & 3 & $\begin{array}{l}43.657707^{\circ} \\
-79.450390^{\circ}\end{array}$ & $\begin{array}{l}\text { Public (West } \\
\text { Toronto } \\
\text { Railpath) }\end{array}$ & New tree. \\
\hline Chinese Elm & $\begin{array}{l}\text { Ulmus } \\
\text { parvifolia }\end{array}$ & defoliation & 1 & $\begin{array}{l}43.657731^{\circ}, \\
-79.450409^{\circ}\end{array}$ & $\begin{array}{l}\text { Public (West } \\
\text { Toronto } \\
\text { Railpath) }\end{array}$ & New tree. \\
\hline Chinese Elm & $\begin{array}{l}\text { Ulmus } \\
\text { parvifolia }\end{array}$ & defoliation & 1 & $\begin{array}{l}43.657767^{\circ} \\
-79.450429^{\circ}\end{array}$ & $\begin{array}{l}\text { Public (West } \\
\text { Toronto } \\
\text { Railpath) }\end{array}$ & New tree. \\
\hline Chinese Elm & $\begin{array}{l}\text { Ulmus } \\
\text { parvifolia }\end{array}$ & good condition & 0 & $\begin{array}{l}43.657770^{\circ}, \\
-79.450455^{\circ}\end{array}$ & $\begin{array}{l}\text { Public (West } \\
\text { Toronto } \\
\text { Railpath) }\end{array}$ & New tree. \\
\hline Chinese Elm & $\begin{array}{l}\text { Ulmus } \\
\text { parvifolia }\end{array}$ & tree lean & 1 & $\begin{array}{l}43.657787^{\circ} \\
-79.450452^{\circ}\end{array}$ & $\begin{array}{l}\text { Public (West } \\
\text { Toronto } \\
\text { Railpath) }\end{array}$ & New tree. \\
\hline Chinese Elm & $\begin{array}{l}\text { Ulmus } \\
\text { parvifolia }\end{array}$ & good condition & 0 & $\begin{array}{l}43.657830^{\circ}, \\
-79.450482^{\circ}\end{array}$ & $\begin{array}{l}\text { Public (West } \\
\text { Toronto } \\
\text { Railpath) }\end{array}$ & New tree. \\
\hline Chinese Elm & $\begin{array}{l}\text { Ulmus } \\
\text { parvifolia }\end{array}$ & tree lean, defoliation & 2 & $\begin{array}{l}43.657831^{\circ} \\
-79.450515^{\circ}\end{array}$ & $\begin{array}{l}\text { Public (West } \\
\text { Toronto } \\
\text { Railpath) }\end{array}$ & New tree. \\
\hline Chinese Elm & $\begin{array}{l}\text { Ulmus } \\
\text { parvifolia }\end{array}$ & tree lean, defoliation & 2 & $\begin{array}{l}43.657832^{\circ} \\
-79.450507^{\circ}\end{array}$ & $\begin{array}{l}\text { Public (West } \\
\text { Toronto } \\
\text { Railpath) }\end{array}$ & New tree. \\
\hline Chinese Elm & $\begin{array}{l}\text { Ulmus } \\
\text { parvifolia }\end{array}$ & good condition & 0 & $\begin{array}{l}43.657833^{\circ}, \\
-79.450489^{\circ}\end{array}$ & $\begin{array}{l}\text { Public (West } \\
\text { Toronto } \\
\text { Railpath) }\end{array}$ & New tree. \\
\hline Chinese Elm & $\begin{array}{l}\text { Ulmus } \\
\text { parvifolia }\end{array}$ & tree lean & 1 & $\begin{array}{l}43.657841^{\circ}, \\
-79.450534^{\circ}\end{array}$ & $\begin{array}{l}\text { Public (West } \\
\text { Toronto } \\
\text { Railpath) }\end{array}$ & New tree. \\
\hline Chinese Elm & $\begin{array}{l}\text { Ulmus } \\
\text { parvifolia }\end{array}$ & tree lean & 1 & $\begin{array}{l}43.657847^{\circ}, \\
-79.450500^{\circ}\end{array}$ & $\begin{array}{l}\text { Public (West } \\
\text { Toronto } \\
\text { Railpath) }\end{array}$ & New tree. \\
\hline Chinese Elm & $\begin{array}{l}\text { Ulmus } \\
\text { parvifolia }\end{array}$ & defoliation & 1 & $\begin{array}{l}43.657962^{\circ}, \\
-79.450633^{\circ}\end{array}$ & $\begin{array}{l}\text { Public (West } \\
\text { Toronto } \\
\text { Railpath) }\end{array}$ & New tree. \\
\hline Chinese Elm & $\begin{array}{l}\text { Ulmus } \\
\text { parvifolia }\end{array}$ & dead/broken branches & 2 & $\begin{array}{l}43.657963^{\circ}, \\
-79.450620^{\circ}\end{array}$ & $\begin{array}{l}\text { Public (West } \\
\text { Toronto } \\
\text { Railpath) }\end{array}$ & New tree. \\
\hline Chinese Elm & $\begin{array}{l}\text { Ulmus } \\
\text { parvifolia }\end{array}$ & defoliation & 1 & $\begin{array}{l}43.658030^{\circ}, \\
-79.450678^{\circ}\end{array}$ & $\begin{array}{l}\text { Public (West } \\
\text { Toronto } \\
\text { Railpath) }\end{array}$ & New tree. \\
\hline Chinese Elm & $\begin{array}{l}\text { Ulmus } \\
\text { parvifolia }\end{array}$ & defoliation & 1 & $\begin{array}{l}43.658106^{\circ}, \\
-79.450750^{\circ}\end{array}$ & $\begin{array}{l}\text { Public (West } \\
\text { Toronto } \\
\text { Railpath) }\end{array}$ & New tree. \\
\hline Chinese Elm & $\begin{array}{l}\text { Ulmus } \\
\text { parvifolia }\end{array}$ & defoliation & 1 & $\begin{array}{l}43.658157^{\circ}, \\
-79.450818^{\circ}\end{array}$ & $\begin{array}{l}\text { Public (West } \\
\text { Toronto } \\
\text { Railpath) }\end{array}$ & New tree. \\
\hline Chinese Elm & $\begin{array}{l}\text { Ulmus } \\
\text { parvifolia }\end{array}$ & defoliation & 1 & $\begin{array}{l}43.658240^{\circ}, \\
-79.450857^{\circ}\end{array}$ & $\begin{array}{l}\text { Public (West } \\
\text { Toronto } \\
\text { Railpath) }\end{array}$ & New tree. \\
\hline Chinese Elm & $\begin{array}{l}\text { Ulmus } \\
\text { parvifolia }\end{array}$ & $\begin{array}{l}\text { tree lean,defoliation, cracks } \\
\text { on trunk }\end{array}$ & 3 & $\begin{array}{l}43.658793^{\circ}, \\
-79.451416^{\circ}\end{array}$ & $\begin{array}{l}\text { Public (West } \\
\text { Toronto } \\
\text { Railpath) }\end{array}$ & New tree. \\
\hline Chinese Elm & $\begin{array}{l}\text { Ulmus } \\
\text { parvifolia }\end{array}$ & defoliation & 1 & $\begin{array}{l}43.658804^{\circ}, \\
-79.451427^{\circ}\end{array}$ & $\begin{array}{l}\text { Public (West } \\
\text { Toronto } \\
\text { Railpath) }\end{array}$ & New tree. \\
\hline Chinese Elm & $\begin{array}{l}\text { Ulmus } \\
\text { parvifolia }\end{array}$ & cracks on trunk & 1 & $\begin{array}{l}43.658808^{\circ} \\
-79.451441^{\circ}\end{array}$ & $\begin{array}{l}\text { Public (West } \\
\text { Toronto } \\
\text { Railpath) }\end{array}$ & New tree. \\
\hline Chinese Elm & $\begin{array}{l}\text { Ulmus } \\
\text { parvifolia }\end{array}$ & dead/broken branches & 2 & $\begin{array}{l}43.658813^{\circ}, \\
-79.451463^{\circ}\end{array}$ & $\begin{array}{l}\text { Public (West } \\
\text { Toronto } \\
\text { Railpath) }\end{array}$ & New tree. \\
\hline Chinese Elm & $\begin{array}{l}\text { Ulmus } \\
\text { parvifolia }\end{array}$ & defoliation & 1 & $\begin{array}{l}43.658832^{\circ}, \\
-79.451474^{\circ}\end{array}$ & $\begin{array}{l}\text { Public (West } \\
\text { Toronto } \\
\text { Railpath) }\end{array}$ & New tree. \\
\hline Chinese Elm & $\begin{array}{l}\text { Ulmus } \\
\text { parvifolia }\end{array}$ & good condition & 0 & $\begin{array}{l}43.658844^{\circ}, \\
-79.450463^{\circ}\end{array}$ & $\begin{array}{l}\text { Public (West } \\
\text { Toronto } \\
\text { Railpath) }\end{array}$ & New tree. \\
\hline
\end{tabular}




\begin{tabular}{|c|c|c|c|c|c|c|}
\hline Chinese Elm & $\begin{array}{l}\text { Ulmus } \\
\text { parvifolia }\end{array}$ & tree lean & 1 & $\begin{array}{l}43.658844^{\circ} \\
-79.451463^{\circ}\end{array}$ & $\begin{array}{l}\text { Public (West } \\
\text { Toronto } \\
\text { Railpath) }\end{array}$ & New tree. \\
\hline Chinese Elm & $\begin{array}{l}\text { Ulmus } \\
\text { parvifolia }\end{array}$ & tree lean, defoliation & 2 & $\begin{array}{l}43.658857^{\circ}, \\
-79.451494^{\circ}\end{array}$ & $\begin{array}{l}\text { Public (West } \\
\text { Toronto } \\
\text { Railpath) }\end{array}$ & New tree. \\
\hline Chinese Elm & $\begin{array}{l}\text { Ulmus } \\
\text { parvifolia }\end{array}$ & tree lean, defoliation & 2 & $\begin{array}{l}43.658875^{\circ} \\
-79.451527^{\circ}\end{array}$ & $\begin{array}{l}\text { Public (West } \\
\text { Toronto } \\
\text { Railpath) }\end{array}$ & New tree. \\
\hline Chinese Elm & $\begin{array}{l}\text { Ulmus } \\
\text { parvifolia }\end{array}$ & tree lean, defoliation & 2 & $\begin{array}{l}43.658878^{\circ} \\
-79.451521^{\circ}\end{array}$ & $\begin{array}{l}\text { Public (West } \\
\text { Toronto } \\
\text { Railpath) }\end{array}$ & New tree. \\
\hline Chinese Elm & $\begin{array}{l}\text { Ulmus } \\
\text { parvifolia }\end{array}$ & tree lean, defoliation & 2 & $\begin{array}{l}43.658882^{\circ} \\
-79.451512^{\circ}\end{array}$ & $\begin{array}{l}\text { Public (West } \\
\text { Toronto } \\
\text { Railpath) }\end{array}$ & New tree. \\
\hline Chinese Elm & $\begin{array}{l}\text { Ulmus } \\
\text { parvifolia }\end{array}$ & good condition & 0 & $\begin{array}{l}43.658888^{\circ} \\
-79.451507^{\circ}\end{array}$ & $\begin{array}{l}\text { Public (West } \\
\text { Toronto } \\
\text { Railpath) }\end{array}$ & New tree. \\
\hline Chinese Elm & $\begin{array}{l}\text { Ulmus } \\
\text { parvifolia }\end{array}$ & cracks/cankers on trunk & 3 & $\begin{array}{l}43.658900^{\circ}, \\
-79.451523^{\circ}\end{array}$ & $\begin{array}{l}\text { Public (West } \\
\text { Toronto } \\
\text { Railpath) }\end{array}$ & New tree. \\
\hline Chinese Elm & $\begin{array}{l}\text { Ulmus } \\
\text { parvifolia }\end{array}$ & good condition & 0 & $\begin{array}{l}43.658900^{\circ} \\
-79.451537^{\circ}\end{array}$ & $\begin{array}{l}\text { Public (West } \\
\text { Toronto } \\
\text { Railpath) }\end{array}$ & New tree. \\
\hline Chinese Elm & $\begin{array}{l}\text { Ulmus } \\
\text { parvifolia }\end{array}$ & cankers on trunk & 2 & $\begin{array}{l}43.658903^{\circ} \\
-79.451504^{\circ}\end{array}$ & $\begin{array}{l}\text { Public (West } \\
\text { Toronto } \\
\text { Railpath) }\end{array}$ & New tree. \\
\hline Chinese Elm & $\begin{array}{l}\text { Ulmus } \\
\text { parvifolia }\end{array}$ & good condition & 0 & $\begin{array}{l}43.658906^{\circ} \\
-79.451554^{\circ}\end{array}$ & $\begin{array}{l}\text { Public (West } \\
\text { Toronto } \\
\text { Railpath) }\end{array}$ & New tree. \\
\hline Chinese Elm & $\begin{array}{l}\text { Ulmus } \\
\text { parvifolia }\end{array}$ & defoliation & 1 & $\begin{array}{l}43.658948^{\circ}, \\
-79.451573^{\circ}\end{array}$ & $\begin{array}{l}\text { Public (West } \\
\text { Toronto } \\
\text { Railpath) }\end{array}$ & New tree. \\
\hline Chinese Elm & $\begin{array}{l}\text { Ulmus } \\
\text { parvifolia }\end{array}$ & defoliation & 1 & $\begin{array}{l}43.658948^{\circ}, \\
-79.451591^{\circ}\end{array}$ & $\begin{array}{l}\text { Public (West } \\
\text { Toronto } \\
\text { Railpath) }\end{array}$ & New tree. \\
\hline Chinese Elm & $\begin{array}{l}\text { Ulmus } \\
\text { parvifolia }\end{array}$ & defoliation & 1 & $\begin{array}{l}43.658950^{\circ}, \\
-79.451600^{\circ}\end{array}$ & $\begin{array}{l}\text { Public (West } \\
\text { Toronto } \\
\text { Railpath) }\end{array}$ & New tree. \\
\hline Chinese Elm & $\begin{array}{l}\text { Ulmus } \\
\text { parvifolia }\end{array}$ & $\begin{array}{l}\text { defoliation, tree leaning } \\
\text { badly }\end{array}$ & 3 & $\begin{array}{l}43.658957^{\circ}, \\
-79.451582^{\circ}\end{array}$ & $\begin{array}{l}\text { Public (West } \\
\text { Toronto } \\
\text { Railpath) }\end{array}$ & New tree. \\
\hline Chinese Elm & $\begin{array}{l}\text { Ulmus } \\
\text { parvifolia }\end{array}$ & defoliation & 1 & $\begin{array}{l}43.658961^{\circ}, \\
-79.451579^{\circ}\end{array}$ & $\begin{array}{l}\text { Public (West } \\
\text { Toronto } \\
\text { Railpath) }\end{array}$ & New tree. \\
\hline Chinese Elm & $\begin{array}{l}\text { Ulmus } \\
\text { parvifolia }\end{array}$ & defoliation & 1 & $\begin{array}{l}43.658961^{\circ}, \\
-79.451594^{\circ}\end{array}$ & $\begin{array}{l}\text { Public (West } \\
\text { Toronto } \\
\text { Railpath) }\end{array}$ & New tree. \\
\hline Chinese Elm & $\begin{array}{l}\text { Ulmus } \\
\text { parvifolia }\end{array}$ & defoliation & 1 & $\begin{array}{l}43.658962^{\circ}, \\
-79.451608^{\circ}\end{array}$ & $\begin{array}{l}\text { Public (West } \\
\text { Toronto } \\
\text { Railpath) }\end{array}$ & New tree. \\
\hline Chinese Elm & $\begin{array}{l}\text { Ulmus } \\
\text { parvifolia }\end{array}$ & defoliation & 1 & $\begin{array}{l}43.658965^{\circ}, \\
-79.451590^{\circ}\end{array}$ & $\begin{array}{l}\text { Public (West } \\
\text { Toronto } \\
\text { Railpath) }\end{array}$ & New tree. \\
\hline Chinese Elm & $\begin{array}{l}\text { Ulmus } \\
\text { parvifolia }\end{array}$ & defoliation & 1 & $\begin{array}{l}43.658985^{\circ}, \\
-79.451639^{\circ}\end{array}$ & $\begin{array}{l}\text { Public (West } \\
\text { Toronto } \\
\text { Railpath) }\end{array}$ & New tree. \\
\hline Chinese Elm & $\begin{array}{l}\text { Ulmus } \\
\text { parvifolia }\end{array}$ & tree lean, defoliation & 2 & $\begin{array}{l}43.658987^{\circ} \\
-79.451598^{\circ}\end{array}$ & $\begin{array}{l}\text { Public (West } \\
\text { Toronto } \\
\text { Railpath) }\end{array}$ & New tree. \\
\hline Chinese Elm & $\begin{array}{l}\text { Ulmus } \\
\text { parvifolia }\end{array}$ & defoliation & 1 & $\begin{array}{l}43.659277^{\circ}, \\
-79.451932^{\circ}\end{array}$ & $\begin{array}{l}\text { Public (West } \\
\text { Toronto } \\
\text { Railpath) }\end{array}$ & New tree. \\
\hline Chinese Elm & $\begin{array}{l}\text { Ulmus } \\
\text { parvifolia }\end{array}$ & defoliation & 1 & $\begin{array}{l}43.659284^{\circ}, \\
-79.451928^{\circ}\end{array}$ & $\begin{array}{l}\text { Public (West } \\
\text { Toronto } \\
\text { Railpath) }\end{array}$ & New tree. \\
\hline Chinese Elm & $\begin{array}{l}\text { Ulmus } \\
\text { parvifolia }\end{array}$ & peeling bark & 1 & $\begin{array}{l}43.657212^{\circ}, \\
-79.449860^{\circ}\end{array}$ & $\begin{array}{l}\text { Public (West } \\
\text { Toronto } \\
\text { Railpath) }\end{array}$ & New tree. \\
\hline
\end{tabular}




\begin{tabular}{|c|c|c|c|c|c|c|}
\hline $\begin{array}{l}\text { Freeman } \\
\text { Maple }\end{array}$ & $\begin{array}{l}\text { Acer } \mathrm{x} \\
\text { freemanii }\end{array}$ & good condition & 0 & $\begin{array}{l}43.660025^{\circ} \\
-79.452716^{\circ}\end{array}$ & $\begin{array}{l}\text { Public (West } \\
\text { Toronto } \\
\text { Railpath) }\end{array}$ & New tree. \\
\hline $\begin{array}{l}\text { Freeman } \\
\text { Maple }\end{array}$ & $\begin{array}{l}\text { Acer } x \\
\text { freemanii }\end{array}$ & good condition & 0 & $\begin{array}{l}43.660062^{\circ}, \\
-79.452747^{\circ}\end{array}$ & $\begin{array}{l}\text { Public (West } \\
\text { Toronto } \\
\text { Railpath) }\end{array}$ & New tree. \\
\hline $\begin{array}{l}\text { Freeman } \\
\text { Maple }\end{array}$ & $\begin{array}{l}\text { Acer } x \\
\text { freemanii }\end{array}$ & good condition & 0 & $\begin{array}{l}43.660114^{\circ}, \\
-79.452808^{\circ}\end{array}$ & $\begin{array}{l}\text { Public (West } \\
\text { Toronto } \\
\text { Railpath) }\end{array}$ & New tree. \\
\hline $\begin{array}{l}\text { Freeman } \\
\text { Maple }\end{array}$ & $\begin{array}{l}\text { Acer } x \\
\text { freemanii }\end{array}$ & good condition & 0 & $\begin{array}{l}43.660121^{\circ}, \\
-79.452721^{\circ}\end{array}$ & $\begin{array}{l}\text { Public (West } \\
\text { Toronto } \\
\text { Railpath) }\end{array}$ & New tree. \\
\hline $\begin{array}{l}\text { Freeman } \\
\text { Maple }\end{array}$ & $\begin{array}{l}\text { Acer } x \\
\text { freemanii }\end{array}$ & tree lean & 1 & $\begin{array}{l}43.660141^{\circ} \\
-79.452836^{\circ}\end{array}$ & $\begin{array}{l}\text { Public (West } \\
\text { Toronto } \\
\text { Railpath) }\end{array}$ & New tree. \\
\hline $\begin{array}{l}\text { Freeman } \\
\text { Maple }\end{array}$ & $\begin{array}{l}\text { Acer } \mathrm{x} \\
\text { freemanii }\end{array}$ & good condition & 0 & $\begin{array}{l}43.660148^{\circ} \\
-79.452837^{\circ}\end{array}$ & $\begin{array}{l}\text { Public (West } \\
\text { Toronto } \\
\text { Railpath) }\end{array}$ & New tree. \\
\hline $\begin{array}{l}\text { Freeman } \\
\text { Maple }\end{array}$ & $\begin{array}{l}\text { Acer x } \\
\text { freemanii }\end{array}$ & good condition & 0 & $\begin{array}{l}43.660178^{\circ} \\
-79.452872^{\circ}\end{array}$ & $\begin{array}{l}\text { Public (West } \\
\text { Toronto } \\
\text { Railpath) }\end{array}$ & New tree. \\
\hline $\begin{array}{l}\text { Freeman } \\
\text { Maple }\end{array}$ & $\begin{array}{l}\text { Acer } x \\
\text { freemanii }\end{array}$ & good condition & 0 & $\begin{array}{l}43.660204^{\circ}, \\
-79.452899^{\circ}\end{array}$ & $\begin{array}{l}\text { Public (West } \\
\text { Toronto } \\
\text { Railpath) }\end{array}$ & New tree. \\
\hline $\begin{array}{l}\text { Freeman } \\
\text { Maple }\end{array}$ & $\begin{array}{l}\text { Acer } \mathrm{x} \\
\text { freemanii }\end{array}$ & good condition & 0 & $\begin{array}{l}43.660238^{\circ} \\
-79.452931^{\circ}\end{array}$ & $\begin{array}{l}\text { Public (West } \\
\text { Toronto } \\
\text { Railpath) }\end{array}$ & New tree. \\
\hline $\begin{array}{l}\text { Freeman } \\
\text { Maple }\end{array}$ & $\begin{array}{l}\text { Acer } x \\
\text { freemanii }\end{array}$ & good condition & 0 & $\begin{array}{l}43.660292^{\circ} \\
-79.452987^{\circ}\end{array}$ & $\begin{array}{l}\text { Public (West } \\
\text { Toronto } \\
\text { Railpath) }\end{array}$ & New tree. \\
\hline $\begin{array}{l}\text { Freeman } \\
\text { Maple }\end{array}$ & $\begin{array}{l}\text { Acer } \mathrm{x} \\
\text { freemanii }\end{array}$ & good condition & 0 & $\begin{array}{l}43.660326^{\circ}, \\
-79.453022^{\circ}\end{array}$ & $\begin{array}{l}\text { Public (West } \\
\text { Toronto } \\
\text { Railpath) }\end{array}$ & New tree. \\
\hline $\begin{array}{l}\text { Freeman } \\
\text { Maple }\end{array}$ & $\begin{array}{l}\text { Acer } x \\
\text { freemanii }\end{array}$ & good condition & 0 & $\begin{array}{l}43.660357^{\circ}, \\
-79.453049^{\circ}\end{array}$ & $\begin{array}{l}\text { Public (West } \\
\text { Toronto } \\
\text { Railpath) }\end{array}$ & New tree. \\
\hline $\begin{array}{l}\text { Freeman } \\
\text { Maple }\end{array}$ & $\begin{array}{l}\text { Acer } x \\
\text { freemanii }\end{array}$ & good condition & 0 & $\begin{array}{l}43.660399^{\circ}, \\
-79.453087^{\circ}\end{array}$ & $\begin{array}{l}\text { Public (West } \\
\text { Toronto } \\
\text { Railpath) }\end{array}$ & New tree. \\
\hline $\begin{array}{l}\text { Manitoba } \\
\text { Maple }\end{array}$ & Acer negundo & good condition & 0 & $\begin{array}{l}43.657601^{\circ}, \\
-79.450258^{\circ}\end{array}$ & $\begin{array}{l}\text { Public (West } \\
\text { Toronto } \\
\text { Railpath) }\end{array}$ & New tree. \\
\hline $\begin{array}{l}\text { Manitoba } \\
\text { Maple }\end{array}$ & Acer negundo & tree lean & 1 & $\begin{array}{l}43.657797^{\circ} \\
-79.450467^{\circ}\end{array}$ & $\begin{array}{l}\text { Public (West } \\
\text { Toronto } \\
\text { Railpath) }\end{array}$ & New tree. \\
\hline $\begin{array}{l}\text { Manitoba } \\
\text { Maple }\end{array}$ & Acer negundo & tree lean & 1 & $\begin{array}{l}43.657845^{\circ} \\
-79.450527^{\circ}\end{array}$ & $\begin{array}{l}\text { Public (West } \\
\text { Toronto } \\
\text { Railpath) }\end{array}$ & New tree. \\
\hline $\begin{array}{l}\text { Manitoba } \\
\text { Maple }\end{array}$ & Acer negundo & tree lean & 2 & $\begin{array}{l}43.658512^{\circ} \\
-79.451137^{\circ}\end{array}$ & $\begin{array}{l}\text { Public (West } \\
\text { Toronto } \\
\text { Railpath) }\end{array}$ & New tree. \\
\hline $\begin{array}{l}\text { Manitoba } \\
\text { Maple }\end{array}$ & Acer negundo & defoliation & 1 & $\begin{array}{l}43.658876^{\circ}, \\
-79.451510^{\circ}\end{array}$ & $\begin{array}{l}\text { Public (West } \\
\text { Toronto } \\
\text { Railpath) }\end{array}$ & New tree. \\
\hline $\begin{array}{l}\text { Manitoba } \\
\text { Maple }\end{array}$ & Acer negundo & $\begin{array}{l}\text { tree lean, dead/broken } \\
\text { branches }\end{array}$ & 3 & $\begin{array}{l}43.659334^{\circ}, \\
-79.451978^{\circ}\end{array}$ & $\begin{array}{l}\text { Public (West } \\
\text { Toronto } \\
\text { Railpath) }\end{array}$ & New tree. \\
\hline $\begin{array}{l}\text { Manitoba } \\
\text { Maple }\end{array}$ & Acer negundo & tree lean & 1 & $\begin{array}{l}43.659680^{\circ} \\
-79.452295^{\circ}\end{array}$ & $\begin{array}{l}\text { Public (West } \\
\text { Toronto } \\
\text { Railpath) }\end{array}$ & New tree. \\
\hline $\begin{array}{l}\text { Manitoba } \\
\text { Maple }\end{array}$ & Acer negundo & tree lean & 1 & $\begin{array}{l}43.659750^{\circ}, \\
-79.452343^{\circ}\end{array}$ & $\begin{array}{l}\text { Public (West } \\
\text { Toronto } \\
\text { Railpath) }\end{array}$ & New tree. \\
\hline $\begin{array}{l}\text { Manitoba } \\
\text { Maple }\end{array}$ & Acer negundo & good condition & 0 & $\begin{array}{l}43.660267^{\circ}, \\
-79.452800^{\circ}\end{array}$ & $\begin{array}{l}\text { Public (West } \\
\text { Toronto } \\
\text { Railpath) }\end{array}$ & New tree. \\
\hline $\begin{array}{l}\text { Manitoba } \\
\text { Maple }\end{array}$ & Acer negundo & good condition & 0 & $\begin{array}{l}43.660283^{\circ}, \\
-79.452817^{\circ}\end{array}$ & $\begin{array}{l}\text { Public (West } \\
\text { Toronto } \\
\text { Railpath) }\end{array}$ & New tree. \\
\hline
\end{tabular}




\begin{tabular}{|c|c|c|c|c|c|c|}
\hline $\begin{array}{l}\text { Manitoba } \\
\text { Maple }\end{array}$ & Acer negundo & good condition & 0 & $\begin{array}{l}43.660310^{\circ}, \\
-79.452848^{\circ}\end{array}$ & $\begin{array}{l}\text { Public (West } \\
\text { Toronto } \\
\text { Railpath) }\end{array}$ & New tree. \\
\hline $\begin{array}{l}\text { Manitoba } \\
\text { Maple }\end{array}$ & Acer negundo & tree lean & 1 & $\begin{array}{l}43.658939^{\circ}, \\
-79.451549^{\circ}\end{array}$ & $\begin{array}{l}\text { Public (West } \\
\text { Toronto } \\
\text { Railpath) }\end{array}$ & \\
\hline $\begin{array}{l}\text { Manitoba } \\
\text { Maple }\end{array}$ & Acer negundo & tree lean & 1 & $\begin{array}{l}43.658958^{\circ}, \\
-79.451573^{\circ}\end{array}$ & $\begin{array}{l}\text { Public (West } \\
\text { Toronto } \\
\text { Railpath) }\end{array}$ & \\
\hline $\begin{array}{l}\text { Manitoba } \\
\text { Maple }\end{array}$ & Acer negundo & tree lean & 1 & $\begin{array}{l}43.658963^{\circ}, \\
-79.451612^{\circ}\end{array}$ & $\begin{array}{l}\text { Public (West } \\
\text { Toronto } \\
\text { Railpath) }\end{array}$ & \\
\hline $\begin{array}{l}\text { Manitoba } \\
\text { Maple }\end{array}$ & Acer negundo & tree lean & 1 & $\begin{array}{l}43.658964^{\circ}, \\
-79.451590^{\circ}\end{array}$ & $\begin{array}{l}\text { Public (West } \\
\text { Toronto } \\
\text { Railpath) }\end{array}$ & \\
\hline $\begin{array}{l}\text { Manitoba } \\
\text { Maple }\end{array}$ & Acer negundo & tree lean & 1 & $\begin{array}{l}43.659015^{\circ}, \\
-79.451635^{\circ}\end{array}$ & $\begin{array}{l}\text { Public (West } \\
\text { Toronto } \\
\text { Railpath) }\end{array}$ & \\
\hline $\begin{array}{l}\text { Manitoba } \\
\text { Maple }\end{array}$ & Acer negundo & tree lean & 1 & $\begin{array}{l}43.659029^{\circ}, \\
-79.451648^{\circ}\end{array}$ & $\begin{array}{l}\text { Public (West } \\
\text { Toronto } \\
\text { Railpath) }\end{array}$ & \\
\hline $\begin{array}{l}\text { Manitoba } \\
\text { Maple }\end{array}$ & Acer negundo & tree lean & 1 & $\begin{array}{l}43.659049^{\circ}, \\
-79.451679^{\circ}\end{array}$ & $\begin{array}{l}\text { Public (West } \\
\text { Toronto } \\
\text { Railpath) }\end{array}$ & \\
\hline $\begin{array}{l}\text { Manitoba } \\
\text { Maple }\end{array}$ & Acer negundo & tree lean & 1 & $\begin{array}{l}43.659259^{\circ}, \\
-79.451911^{\circ}\end{array}$ & $\begin{array}{l}\text { Public (West } \\
\text { Toronto } \\
\text { Railpath) }\end{array}$ & \\
\hline $\begin{array}{l}\text { Manitoba } \\
\text { Maple }\end{array}$ & Acer negundo & tree lean, defoliation & 2 & $\begin{array}{l}43.659268^{\circ} \\
-79.451925^{\circ}\end{array}$ & $\begin{array}{l}\text { Public (West } \\
\text { Toronto } \\
\text { Railpath) }\end{array}$ & \\
\hline $\begin{array}{l}\text { Manitoba } \\
\text { Maple }\end{array}$ & Acer negundo & cracks on trunk & 1 & $\begin{array}{l}43.659270^{\circ}, \\
-79.451912^{\circ}\end{array}$ & $\begin{array}{l}\text { Public (West } \\
\text { Toronto } \\
\text { Railpath) }\end{array}$ & \\
\hline $\begin{array}{l}\text { Manitoba } \\
\text { Maple }\end{array}$ & Acer negundo & $\begin{array}{l}\text { tree lean, dead/broken } \\
\text { branches }\end{array}$ & 3 & $\begin{array}{l}43.659347^{\circ}, \\
-79.451964^{\circ}\end{array}$ & $\begin{array}{l}\text { Public (West } \\
\text { Toronto } \\
\text { Railpath) }\end{array}$ & \\
\hline $\begin{array}{l}\text { Manitoba } \\
\text { Maple }\end{array}$ & Acer negundo & tree lean & 1 & $\begin{array}{l}43.659719^{\circ}, \\
-79.452331^{\circ}\end{array}$ & $\begin{array}{l}\text { Public (West } \\
\text { Toronto } \\
\text { Railpath) }\end{array}$ & \\
\hline $\begin{array}{l}\text { Manitoba } \\
\text { Maple }\end{array}$ & Acer negundo & tree lean, peeling bark & 2 & $\begin{array}{l}43.659812^{\circ}, \\
-79.452431^{\circ}\end{array}$ & $\begin{array}{l}\text { Public (West } \\
\text { Toronto } \\
\text { Railpath) }\end{array}$ & \\
\hline Paper Birch & $\begin{array}{l}\text { Betula } \\
\text { papyrifera }\end{array}$ & good condition & 0 & $\begin{array}{l}43.659187^{\circ}, \\
-79.451822^{\circ}\end{array}$ & $\begin{array}{l}\text { Public (West } \\
\text { Toronto } \\
\text { Railpath) }\end{array}$ & New tree. \\
\hline Paper Birch & $\begin{array}{l}\text { Betula } \\
\text { papyrifera }\end{array}$ & good condition & 0 & $\begin{array}{l}43.659221^{\circ} \\
-79.451854^{\circ}\end{array}$ & $\begin{array}{l}\text { Public (West } \\
\text { Toronto } \\
\text { Railpath) }\end{array}$ & New tree. \\
\hline Paper Birch & $\begin{array}{l}\text { Betula } \\
\text { papyrifera }\end{array}$ & good condition & 0 & $\begin{array}{l}43.659233^{\circ} \\
-79.451870^{\circ}\end{array}$ & $\begin{array}{l}\text { Public (West } \\
\text { Toronto } \\
\text { Railpath) }\end{array}$ & New tree. \\
\hline Paper Birch & $\begin{array}{l}\text { Betula } \\
\text { papyrifera }\end{array}$ & good condition & 0 & $\begin{array}{l}43.659245^{\circ} \\
-79.451886^{\circ}\end{array}$ & $\begin{array}{l}\text { Public (West } \\
\text { Toronto } \\
\text { Railpath) }\end{array}$ & New tree. \\
\hline Paper Birch & $\begin{array}{l}\text { Betula } \\
\text { papyrifera }\end{array}$ & $\begin{array}{l}\text { tree lean, dead/broken } \\
\text { branches }\end{array}$ & 3 & $\begin{array}{l}43.660370^{\circ}, \\
-79.453096^{\circ}\end{array}$ & $\begin{array}{l}\text { Public (West } \\
\text { Toronto } \\
\text { Railpath) }\end{array}$ & New tree. Near construction. \\
\hline Paper Birch & $\begin{array}{l}\text { Betula } \\
\text { papyrifera }\end{array}$ & tree lean, cracks on trunk & 3 & $\begin{array}{l}43.660374^{\circ}, \\
-79.452975^{\circ}\end{array}$ & $\begin{array}{l}\text { Public (West } \\
\text { Toronto } \\
\text { Railpath) }\end{array}$ & New tree. Near construction. \\
\hline Paper Birch & $\begin{array}{l}\text { Betula } \\
\text { papyrifera }\end{array}$ & tree lean, peeling bark & 2 & $\begin{array}{l}43.660392^{\circ} \\
-79.453115^{\circ}\end{array}$ & $\begin{array}{l}\text { Public (West } \\
\text { Toronto } \\
\text { Railpath) }\end{array}$ & New tree. Near construction. \\
\hline Paper Birch & $\begin{array}{l}\text { Betula } \\
\text { papyrifera }\end{array}$ & $\begin{array}{l}\text { tree lean, cracks along } \\
\text { trunk }\end{array}$ & 2 & $\begin{array}{l}43.660397^{\circ}, \\
-79.452911^{\circ}\end{array}$ & $\begin{array}{l}\text { Public (West } \\
\text { Toronto } \\
\text { Railpath) }\end{array}$ & New tree. Near construction. \\
\hline Paper Birch & $\begin{array}{l}\text { Betula } \\
\text { papyrifera }\end{array}$ & tree lean & 1 & $\begin{array}{l}43.660397^{\circ}, \\
-79.452965^{\circ}\end{array}$ & $\begin{array}{l}\text { Public (West } \\
\text { Toronto } \\
\text { Railpath) }\end{array}$ & New tree. Near construction. \\
\hline
\end{tabular}




\begin{tabular}{|c|c|c|c|c|c|c|}
\hline Paper Birch & $\begin{array}{l}\text { Betula } \\
\text { papyrifera }\end{array}$ & $\begin{array}{l}\text { tree lean, dead/broken } \\
\text { branches }\end{array}$ & 3 & $\begin{array}{l}43.660406^{\circ}, \\
-79.452911^{\circ}\end{array}$ & $\begin{array}{l}\text { Public (West } \\
\text { Toronto } \\
\text { Railpath) }\end{array}$ & New tree. Near construction. \\
\hline Paper Birch & $\begin{array}{l}\text { Betula } \\
\text { papyrifera }\end{array}$ & DEAD & 4 & $\begin{array}{l}43.658321^{\circ}, \\
-79.450957^{\circ}\end{array}$ & $\begin{array}{l}\text { Public (West } \\
\text { Toronto } \\
\text { Railpath) }\end{array}$ & \\
\hline Paper Birch & $\begin{array}{l}\text { Betula } \\
\text { papyrifera }\end{array}$ & good condition & 0 & $\begin{array}{l}43.658341^{\circ}, \\
-79.451009^{\circ}\end{array}$ & $\begin{array}{l}\text { Public (West } \\
\text { Toronto } \\
\text { Railpath) }\end{array}$ & \\
\hline Paper Birch & $\begin{array}{l}\text { Betula } \\
\text { papyrifera }\end{array}$ & DEAD & 4 & $\begin{array}{l}43.658342^{\circ}, \\
-79.450966^{\circ}\end{array}$ & $\begin{array}{l}\text { Public (West } \\
\text { Toronto } \\
\text { Railpath) }\end{array}$ & \\
\hline Paper Birch & $\begin{array}{l}\text { Betula } \\
\text { papyrifera }\end{array}$ & good condition & 0 & $\begin{array}{l}43.660080^{\circ}, \\
-79.452778^{\circ}\end{array}$ & $\begin{array}{l}\text { Public (West } \\
\text { Toronto } \\
\text { Railpath) }\end{array}$ & \\
\hline $\begin{array}{l}\text { Siberian } \\
\text { Elm }\end{array}$ & Ulmus pumila & defoliation & 1 & $\begin{array}{l}43.658965^{\circ} \\
-79.451615^{\circ}\end{array}$ & $\begin{array}{l}\text { Public (West } \\
\text { Toronto } \\
\text { Railpath) }\end{array}$ & New tree. \\
\hline $\begin{array}{l}\text { Siberian } \\
\text { Elm }\end{array}$ & Ulmus pumila & defoliation & 1 & $\begin{array}{l}43.658968^{\circ} \\
-79.451616^{\circ}\end{array}$ & $\begin{array}{l}\text { Public (West } \\
\text { Toronto } \\
\text { Railpath) }\end{array}$ & New tree. \\
\hline $\begin{array}{l}\text { Siberian } \\
\text { Elm }\end{array}$ & Ulmus pumila & defoliation & 1 & $\begin{array}{l}43.658970^{\circ}, \\
-79.451589^{\circ}\end{array}$ & $\begin{array}{l}\text { Public (West } \\
\text { Toronto } \\
\text { Railpath) }\end{array}$ & New tree. \\
\hline $\begin{array}{l}\text { Siberian } \\
\text { Elm }\end{array}$ & Ulmus pumila & good condition & 0 & $\begin{array}{l}43.658971^{\circ} \\
-79.451596^{\circ}\end{array}$ & $\begin{array}{l}\text { Public (West } \\
\text { Toronto } \\
\text { Railpath) }\end{array}$ & New tree. \\
\hline $\begin{array}{l}\text { Siberian } \\
\text { Elm }\end{array}$ & Ulmus pumila & defoliation & 1 & $\begin{array}{l}43.658971^{\circ} \\
-79.451608^{\circ}\end{array}$ & $\begin{array}{l}\text { Public (West } \\
\text { Toronto } \\
\text { Railpath) }\end{array}$ & New tree. \\
\hline $\begin{array}{l}\text { Siberian } \\
\text { Elm }\end{array}$ & Ulmus pumila & cracks on trunk & 1 & $\begin{array}{l}43.658975^{\circ}, \\
-79.451600^{\circ}\end{array}$ & $\begin{array}{l}\text { Public (West } \\
\text { Toronto } \\
\text { Railpath) }\end{array}$ & New tree. \\
\hline $\begin{array}{l}\text { Siberian } \\
\text { Elm }\end{array}$ & Ulmus pumila & tree lean, defoliation & 2 & $\begin{array}{l}43.658979^{\circ}, \\
-79.451595^{\circ}\end{array}$ & $\begin{array}{l}\text { Public (West } \\
\text { Toronto } \\
\text { Railpath) }\end{array}$ & New tree. \\
\hline $\begin{array}{l}\text { Siberian } \\
\text { Elm }\end{array}$ & Ulmus pumila & large crack along trunk & 3 & $\begin{array}{l}43.658985^{\circ}, \\
-79.451603^{\circ}\end{array}$ & $\begin{array}{l}\text { Public (West } \\
\text { Toronto } \\
\text { Railpath) }\end{array}$ & New tree. \\
\hline $\begin{array}{l}\text { Siberian } \\
\text { Elm }\end{array}$ & Ulmus pumila & good condition & 0 & $\begin{array}{l}43.657235^{\circ}, \\
-79.449882^{\circ}\end{array}$ & $\begin{array}{l}\text { Public (West } \\
\text { Toronto } \\
\text { Railpath) }\end{array}$ & New tree. \\
\hline $\begin{array}{l}\text { Siberian } \\
\text { Elm }\end{array}$ & Ulmus pumila & tree lean & 1 & $\begin{array}{l}43.657249^{\circ}, \\
-79.449903^{\circ}\end{array}$ & $\begin{array}{l}\text { Public (West } \\
\text { Toronto } \\
\text { Railpath) }\end{array}$ & New tree. \\
\hline $\begin{array}{l}\text { Siberian } \\
\text { Elm }\end{array}$ & Ulmus pumila & discoloured leaves & 1 & $\begin{array}{l}43.657304^{\circ}, \\
-79.449953^{\circ}\end{array}$ & $\begin{array}{l}\text { Public (West } \\
\text { Toronto } \\
\text { Railpath) }\end{array}$ & New tree. \\
\hline $\begin{array}{l}\text { Siberian } \\
\text { Elm }\end{array}$ & Ulmus pumila & defoliation & 1 & $\begin{array}{l}43.657337^{\circ} \\
-79.449983^{\circ}\end{array}$ & $\begin{array}{l}\text { Public (West } \\
\text { Toronto } \\
\text { Railpath) }\end{array}$ & New tree. \\
\hline $\begin{array}{l}\text { Siberian } \\
\text { Elm }\end{array}$ & Ulmus pumila & tree lean & 1 & $\begin{array}{l}43.657360^{\circ}, \\
-79.450003^{\circ}\end{array}$ & $\begin{array}{l}\text { Public (West } \\
\text { Toronto } \\
\text { Railpath) }\end{array}$ & New tree. \\
\hline $\begin{array}{l}\text { Siberian } \\
\text { Elm }\end{array}$ & Ulmus pumila & good condition & 0 & $\begin{array}{l}43.657384^{\circ}, \\
-79.450017^{\circ}\end{array}$ & $\begin{array}{l}\text { Public (West } \\
\text { Toronto } \\
\text { Railpath) }\end{array}$ & New tree. \\
\hline $\begin{array}{l}\text { Siberian } \\
\text { Elm }\end{array}$ & Ulmus pumila & dead/broken branches & 2 & $\begin{array}{l}43.657430^{\circ}, \\
-79.450063^{\circ}\end{array}$ & $\begin{array}{l}\text { Public (West } \\
\text { Toronto } \\
\text { Railpath) }\end{array}$ & New tree. \\
\hline $\begin{array}{l}\text { Siberian } \\
\text { Elm }\end{array}$ & Ulmus pumila & good condition & 0 & $\begin{array}{l}43.657437^{\circ} \\
-79.450070^{\circ}\end{array}$ & $\begin{array}{l}\text { Public (West } \\
\text { Toronto } \\
\text { Railpath) }\end{array}$ & New tree. \\
\hline $\begin{array}{l}\text { Siberian } \\
\text { Elm }\end{array}$ & Ulmus pumila & good condition & 0 & $\begin{array}{l}43.657447^{\circ}, \\
-79.450072^{\circ}\end{array}$ & $\begin{array}{l}\text { Public (West } \\
\text { Toronto } \\
\text { Railpath) }\end{array}$ & New tree. \\
\hline $\begin{array}{l}\text { Siberian } \\
\text { Elm }\end{array}$ & Ulmus pumila & defoliation & 1 & $\begin{array}{l}43.659668^{\circ}, \\
-79.452311^{\circ}\end{array}$ & $\begin{array}{l}\text { Public (West } \\
\text { Toronto } \\
\text { Railpath) }\end{array}$ & New tree. \\
\hline
\end{tabular}




\begin{tabular}{|c|c|c|c|c|c|c|}
\hline $\begin{array}{l}\text { Siberian } \\
\text { Elm }\end{array}$ & Ulmus pumila & defoliation & 1 & $\begin{array}{l}43.659709^{\circ} \\
-79.452399^{\circ}\end{array}$ & $\begin{array}{l}\text { Public (West } \\
\text { Toronto } \\
\text { Railpath) }\end{array}$ & New tree. \\
\hline $\begin{array}{l}\text { Siberian } \\
\text { Elm }\end{array}$ & Ulmus pumila & dead/broken branches & 2 & $\begin{array}{l}43.657550^{\circ}, \\
-79.450181^{\circ}\end{array}$ & $\begin{array}{l}\text { Public (West } \\
\text { Toronto } \\
\text { Railpath) }\end{array}$ & \\
\hline $\begin{array}{l}\text { Siberian } \\
\text { Elm }\end{array}$ & Ulmus pumila & $\begin{array}{l}\text { dead/broken branches, tree } \\
\text { lean }\end{array}$ & 3 & $\begin{array}{l}43.657877^{\circ} \\
-79.450538^{\circ}\end{array}$ & $\begin{array}{l}\text { Public (West } \\
\text { Toronto } \\
\text { Railpath) }\end{array}$ & \\
\hline $\begin{array}{l}\text { Tree of } \\
\text { Heaven }\end{array}$ & $\begin{array}{l}\text { Ailanthus } \\
\text { altissima }\end{array}$ & dead/broken branches & 2 & $\begin{array}{l}43.658614^{\circ} \\
-79.451238^{\circ}\end{array}$ & $\begin{array}{l}\text { Public (West } \\
\text { Toronto } \\
\text { Railpath) }\end{array}$ & New tree. \\
\hline $\begin{array}{l}\text { Tree of } \\
\text { Heaven }\end{array}$ & $\begin{array}{l}\text { Ailanthus } \\
\text { altissima }\end{array}$ & good condition & 0 & $\begin{array}{l}43.658620^{\circ} \\
-79.451264^{\circ}\end{array}$ & $\begin{array}{l}\text { Public (West } \\
\text { Toronto } \\
\text { Railpath) }\end{array}$ & New tree. \\
\hline $\begin{array}{l}\text { Tree of } \\
\text { Heaven }\end{array}$ & $\begin{array}{l}\text { Ailanthus } \\
\text { altissima }\end{array}$ & good condition & 0 & $\begin{array}{l}43.658636^{\circ} \\
-79.451270^{\circ}\end{array}$ & $\begin{array}{l}\text { Public (West } \\
\text { Toronto } \\
\text { Railpath) }\end{array}$ & New tree. \\
\hline $\begin{array}{l}\text { Tree of } \\
\text { Heaven }\end{array}$ & $\begin{array}{l}\text { Ailanthus } \\
\text { altissima }\end{array}$ & good condition & 0 & $\begin{array}{l}43.658640^{\circ} \\
-79.451297^{\circ}\end{array}$ & $\begin{array}{l}\text { Public (West } \\
\text { Toronto } \\
\text { Railpath) }\end{array}$ & New tree. \\
\hline $\begin{array}{l}\text { Tree of } \\
\text { Heaven }\end{array}$ & $\begin{array}{l}\text { Ailanthus } \\
\text { altissima }\end{array}$ & good condition & 0 & $\begin{array}{l}43.658650^{\circ} \\
-79.451309^{\circ}\end{array}$ & $\begin{array}{l}\text { Public (West } \\
\text { Toronto } \\
\text { Railpath) }\end{array}$ & New tree. \\
\hline $\begin{array}{l}\text { Tree of } \\
\text { Heaven }\end{array}$ & $\begin{array}{l}\text { Ailanthus } \\
\text { altissima }\end{array}$ & good condition & 0 & $\begin{array}{l}43.658656^{\circ} \\
-79.451313^{\circ}\end{array}$ & $\begin{array}{l}\text { Public (West } \\
\text { Toronto } \\
\text { Railpath) }\end{array}$ & New tree. \\
\hline $\begin{array}{l}\text { Tree of } \\
\text { Heaven }\end{array}$ & $\begin{array}{l}\text { Ailanthus } \\
\text { altissima }\end{array}$ & good condition & 0 & $\begin{array}{l}43.658663^{\circ} \\
-79.451286^{\circ}\end{array}$ & $\begin{array}{l}\text { Public (West } \\
\text { Toronto } \\
\text { Railpath) }\end{array}$ & New tree. \\
\hline $\begin{array}{l}\text { Tree of } \\
\text { Heaven }\end{array}$ & $\begin{array}{l}\text { Ailanthus } \\
\text { altissima }\end{array}$ & good condition & 0 & $\begin{array}{l}43.658682^{\circ}, \\
-79.451302^{\circ}\end{array}$ & $\begin{array}{l}\text { Public (West } \\
\text { Toronto } \\
\text { Railpath) } \\
\end{array}$ & New tree. \\
\hline $\begin{array}{l}\text { Tree of } \\
\text { Heaven }\end{array}$ & $\begin{array}{l}\text { Ailanthus } \\
\text { altissima }\end{array}$ & good condition & 0 & $\begin{array}{l}43.658698^{\circ}, \\
-79.451354^{\circ}\end{array}$ & $\begin{array}{l}\text { Public (West } \\
\text { Toronto } \\
\text { Railpath) }\end{array}$ & New tree. \\
\hline $\begin{array}{l}\text { Tree of } \\
\text { Heaven }\end{array}$ & $\begin{array}{l}\text { Ailanthus } \\
\text { altissima }\end{array}$ & good condition & 0 & $\begin{array}{l}43.658703^{\circ}, \\
-79.451321^{\circ}\end{array}$ & $\begin{array}{l}\text { Public (West } \\
\text { Toronto } \\
\text { Railpath) } \\
\end{array}$ & New tree. \\
\hline $\begin{array}{l}\text { Tree of } \\
\text { Heaven }\end{array}$ & $\begin{array}{l}\text { Ailanthus } \\
\text { altissima }\end{array}$ & good condition & 0 & $\begin{array}{l}43.658721^{\circ}, \\
-79.451367^{\circ}\end{array}$ & $\begin{array}{l}\text { Public (West } \\
\text { Toronto } \\
\text { Railpath) }\end{array}$ & New tree. \\
\hline $\begin{array}{l}\text { Tree of } \\
\text { Heaven }\end{array}$ & $\begin{array}{l}\text { Ailanthus } \\
\text { altissima }\end{array}$ & good condition & 0 & $\begin{array}{l}43.658755^{\circ}, \\
-79.451366^{\circ}\end{array}$ & $\begin{array}{l}\text { Public (West } \\
\text { Toronto } \\
\text { Railpath) }\end{array}$ & New tree. \\
\hline $\begin{array}{l}\text { Tree of } \\
\text { Heaven }\end{array}$ & $\begin{array}{l}\text { Ailanthus } \\
\text { altissima }\end{array}$ & good condition & 0 & $\begin{array}{l}43.658774^{\circ}, \\
-79.451397^{\circ}\end{array}$ & $\begin{array}{l}\text { Public (West } \\
\text { Toronto } \\
\text { Railpath) }\end{array}$ & New tree. \\
\hline $\begin{array}{l}\text { Tree of } \\
\text { Heaven }\end{array}$ & $\begin{array}{l}\text { Ailanthus } \\
\text { altissima }\end{array}$ & good condition & 0 & $\begin{array}{l}43.658778^{\circ}, \\
-79.451423^{\circ}\end{array}$ & $\begin{array}{l}\text { Public (West } \\
\text { Toronto } \\
\text { Railpath) }\end{array}$ & New tree. \\
\hline $\begin{array}{l}\text { Tree of } \\
\text { Heaven }\end{array}$ & $\begin{array}{l}\text { Ailanthus } \\
\text { altissima }\end{array}$ & good condition & 0 & $\begin{array}{l}43.658802^{\circ}, \\
-79.451428^{\circ}\end{array}$ & $\begin{array}{l}\text { Public (West } \\
\text { Toronto } \\
\text { Railpath) }\end{array}$ & New tree. \\
\hline $\begin{array}{l}\text { Tree of } \\
\text { Heaven }\end{array}$ & $\begin{array}{l}\text { Ailanthus } \\
\text { altissima }\end{array}$ & tree lean & 1 & $\begin{array}{l}43.658804^{\circ}, \\
-79.451436^{\circ}\end{array}$ & $\begin{array}{l}\text { Public (West } \\
\text { Toronto } \\
\text { Railpath) }\end{array}$ & New tree. \\
\hline $\begin{array}{l}\text { Tree of } \\
\text { Heaven }\end{array}$ & $\begin{array}{l}\text { Ailanthus } \\
\text { altissima }\end{array}$ & dead/broken branches & 2 & $\begin{array}{l}43.658814^{\circ} \\
-79.451425^{\circ}\end{array}$ & $\begin{array}{l}\text { Public (West } \\
\text { Toronto } \\
\text { Railpath) }\end{array}$ & New tree. \\
\hline $\begin{array}{l}\text { Tree of } \\
\text { Heaven }\end{array}$ & $\begin{array}{l}\text { Ailanthus } \\
\text { altissima }\end{array}$ & good condition & 0 & $\begin{array}{l}43.658990^{\circ}, \\
-79.451605^{\circ}\end{array}$ & $\begin{array}{l}\text { Public (West } \\
\text { Toronto } \\
\text { Railpath) } \\
\end{array}$ & New tree. \\
\hline $\begin{array}{l}\text { Tree of } \\
\text { Heaven }\end{array}$ & $\begin{array}{l}\text { Ailanthus } \\
\text { altissima }\end{array}$ & good condition & 0 & $\begin{array}{l}43.658993^{\circ}, \\
-79.451606^{\circ}\end{array}$ & $\begin{array}{l}\text { Public (West } \\
\text { Toronto } \\
\text { Railpath) } \\
\end{array}$ & New tree. \\
\hline $\begin{array}{l}\text { Tree of } \\
\text { Heaven }\end{array}$ & $\begin{array}{l}\text { Ailanthus } \\
\text { altissima }\end{array}$ & good condition & 0 & $\begin{array}{l}43.659284^{\circ}, \\
-79.451939^{\circ}\end{array}$ & $\begin{array}{l}\text { Public (West } \\
\text { Toronto } \\
\text { Railpath) }\end{array}$ & New tree. \\
\hline
\end{tabular}




\begin{tabular}{|c|c|c|c|c|c|c|}
\hline $\begin{array}{l}\text { Tree of } \\
\text { Heaven }\end{array}$ & $\begin{array}{l}\text { Ailanthus } \\
\text { altissima }\end{array}$ & good condition & 0 & $\begin{array}{l}43.659284^{\circ}, \\
-79.451943^{\circ}\end{array}$ & $\begin{array}{l}\text { Public (West } \\
\text { Toronto } \\
\text { Railpath) }\end{array}$ & New tree. \\
\hline $\begin{array}{l}\text { Tree of } \\
\text { Heaven }\end{array}$ & $\begin{array}{l}\text { Ailanthus } \\
\text { altissima }\end{array}$ & good condition & 0 & $\begin{array}{l}43.659286^{\circ}, \\
-79.451929^{\circ}\end{array}$ & $\begin{array}{l}\text { Public (West } \\
\text { Toronto } \\
\text { Railpath) }\end{array}$ & New tree. \\
\hline $\begin{array}{l}\text { Tree of } \\
\text { Heaven }\end{array}$ & $\begin{array}{l}\text { Ailanthus } \\
\text { altissima }\end{array}$ & good condition & 0 & $\begin{array}{l}43.659288^{\circ}, \\
-79.451944^{\circ}\end{array}$ & $\begin{array}{l}\text { Public (West } \\
\text { Toronto } \\
\text { Railpath) }\end{array}$ & New tree. \\
\hline $\begin{array}{l}\text { Tree of } \\
\text { Heaven }\end{array}$ & $\begin{array}{l}\text { Ailanthus } \\
\text { altissima }\end{array}$ & good condition & 0 & $\begin{array}{l}43.659548^{\circ}, \\
-79.452198^{\circ}\end{array}$ & $\begin{array}{l}\text { Public (West } \\
\text { Toronto } \\
\text { Railpath) }\end{array}$ & New tree. \\
\hline $\begin{array}{l}\text { Tree of } \\
\text { Heaven }\end{array}$ & $\begin{array}{l}\text { Ailanthus } \\
\text { altissima }\end{array}$ & good condition & 0 & $\begin{array}{l}43.659567^{\circ}, \\
-79.452194^{\circ}\end{array}$ & $\begin{array}{l}\text { Public (West } \\
\text { Toronto } \\
\text { Railpath) }\end{array}$ & New tree. \\
\hline $\begin{array}{l}\text { Tree of } \\
\text { Heaven }\end{array}$ & $\begin{array}{l}\text { Ailanthus } \\
\text { altissima }\end{array}$ & good condition & 0 & $\begin{array}{l}43.659567^{\circ}, \\
-79.452196^{\circ}\end{array}$ & $\begin{array}{l}\text { Public (West } \\
\text { Toronto } \\
\text { Railpath) }\end{array}$ & New tree. \\
\hline $\begin{array}{l}\text { Tree of } \\
\text { Heaven }\end{array}$ & $\begin{array}{l}\text { Ailanthus } \\
\text { altissima }\end{array}$ & good condition & 0 & $\begin{array}{l}43.659662^{\circ}, \\
-79.452307^{\circ}\end{array}$ & $\begin{array}{l}\text { Public (West } \\
\text { Toronto } \\
\text { Railpath) }\end{array}$ & New tree. \\
\hline $\begin{array}{l}\text { Tree of } \\
\text { Heaven }\end{array}$ & $\begin{array}{l}\text { Ailanthus } \\
\text { altissima }\end{array}$ & good condition & 0 & $\begin{array}{l}43.659692^{\circ}, \\
-79.452310^{\circ}\end{array}$ & $\begin{array}{l}\text { Public (West } \\
\text { Toronto } \\
\text { Railpath) }\end{array}$ & New tree. \\
\hline $\begin{array}{l}\text { Tree of } \\
\text { Heaven }\end{array}$ & $\begin{array}{l}\text { Ailanthus } \\
\text { altissima }\end{array}$ & dead/broken branches & 2 & $\begin{array}{l}43.659847^{\circ}, \\
-79.452416^{\circ}\end{array}$ & $\begin{array}{l}\text { Public (West } \\
\text { Toronto } \\
\text { Railpath) }\end{array}$ & New tree. \\
\hline $\begin{array}{l}\text { Tree of } \\
\text { Heaven }\end{array}$ & $\begin{array}{l}\text { Ailanthus } \\
\text { altissima }\end{array}$ & dead/broken branches & 2 & $\begin{array}{l}43.659882^{\circ}, \\
-79.452496^{\circ}\end{array}$ & $\begin{array}{l}\text { Public (West } \\
\text { Toronto } \\
\text { Railpath) }\end{array}$ & New tree. \\
\hline $\begin{array}{l}\text { Tree of } \\
\text { Heaven }\end{array}$ & $\begin{array}{l}\text { Ailanthus } \\
\text { altissima }\end{array}$ & tree lean, defoliation & 2 & $\begin{array}{l}43.659960^{\circ}, \\
-79.452563^{\circ}\end{array}$ & $\begin{array}{l}\text { Public (West } \\
\text { Toronto } \\
\text { Railpath) }\end{array}$ & New tree. \\
\hline $\begin{array}{l}\text { Tree of } \\
\text { Heaven }\end{array}$ & $\begin{array}{l}\text { Ailanthus } \\
\text { altissima }\end{array}$ & tree lean, defoliation & 2 & $\begin{array}{l}43.659995^{\circ}, \\
-79.452583^{\circ}\end{array}$ & $\begin{array}{l}\text { Public (West } \\
\text { Toronto } \\
\text { Railpath) }\end{array}$ & New tree. \\
\hline $\begin{array}{l}\text { Tree of } \\
\text { Heaven }\end{array}$ & $\begin{array}{l}\text { Ailanthus } \\
\text { altissima }\end{array}$ & tree lean & 1 & $\begin{array}{l}43.660078^{\circ}, \\
-79.452675^{\circ}\end{array}$ & $\begin{array}{l}\text { Public (West } \\
\text { Toronto } \\
\text { Railpath) }\end{array}$ & New tree. \\
\hline $\begin{array}{l}\text { Tree of } \\
\text { Heaven }\end{array}$ & $\begin{array}{l}\text { Ailanthus } \\
\text { altissima }\end{array}$ & tree lean & 1 & $\begin{array}{l}43.660102^{\circ}, \\
-79.452694^{\circ}\end{array}$ & $\begin{array}{l}\text { Public (West } \\
\text { Toronto } \\
\text { Railpath) }\end{array}$ & New tree. \\
\hline $\begin{array}{l}\text { Tree of } \\
\text { Heaven }\end{array}$ & $\begin{array}{l}\text { Ailanthus } \\
\text { altissima }\end{array}$ & good condition & 0 & $\begin{array}{l}43.659391^{\circ}, \\
-79.452033^{\circ}\end{array}$ & $\begin{array}{l}\text { Public (West } \\
\text { Toronto } \\
\text { Railpath) }\end{array}$ & New tree. \\
\hline $\begin{array}{l}\text { Tree of } \\
\text { Heaven }\end{array}$ & $\begin{array}{l}\text { Ailanthus } \\
\text { altissima }\end{array}$ & good condition & 0 & $\begin{array}{l}43.659427^{\circ}, \\
-79.452079^{\circ}\end{array}$ & $\begin{array}{l}\text { Public (West } \\
\text { Toronto } \\
\text { Railpath) }\end{array}$ & New tree. \\
\hline $\begin{array}{l}\text { Tree of } \\
\text { Heaven }\end{array}$ & $\begin{array}{l}\text { Ailanthus } \\
\text { altissima }\end{array}$ & good condition & 0 & $\begin{array}{l}43.659444^{\circ}, \\
-79.452102^{\circ}\end{array}$ & $\begin{array}{l}\text { Public (West } \\
\text { Toronto } \\
\text { Railpath) }\end{array}$ & New tree. \\
\hline $\begin{array}{l}\text { Tree of } \\
\text { Heaven }\end{array}$ & $\begin{array}{l}\text { Ailanthus } \\
\text { altissima }\end{array}$ & good condition & 0 & $\begin{array}{l}43.659470^{\circ}, \\
-79.452122^{\circ}\end{array}$ & $\begin{array}{l}\text { Public (West } \\
\text { Toronto } \\
\text { Railpath) }\end{array}$ & New tree. \\
\hline $\begin{array}{l}\text { Tree of } \\
\text { Heaven }\end{array}$ & $\begin{array}{l}\text { Ailanthus } \\
\text { altissima }\end{array}$ & good condition & 0 & $\begin{array}{l}43.659485^{\circ}, \\
-79.452137^{\circ}\end{array}$ & $\begin{array}{l}\text { Public (West } \\
\text { Toronto } \\
\text { Railpath) }\end{array}$ & New tree. \\
\hline $\begin{array}{l}\text { Tree of } \\
\text { Heaven }\end{array}$ & $\begin{array}{l}\text { Ailanthus } \\
\text { altissima }\end{array}$ & good condition & 0 & $\begin{array}{l}43.659488^{\circ}, \\
-79.452136^{\circ}\end{array}$ & $\begin{array}{l}\text { Public (West } \\
\text { Toronto } \\
\text { Railpath) }\end{array}$ & New tree. \\
\hline $\begin{array}{l}\text { Tree of } \\
\text { Heaven }\end{array}$ & $\begin{array}{l}\text { Ailanthus } \\
\text { altissima }\end{array}$ & good condition & 0 & $\begin{array}{l}43.659503^{\circ}, \\
-79.452126^{\circ}\end{array}$ & $\begin{array}{l}\text { Public (West } \\
\text { Toronto } \\
\text { Railpath) }\end{array}$ & New tree. \\
\hline $\begin{array}{l}\text { Tree of } \\
\text { Heaven }\end{array}$ & $\begin{array}{l}\text { Ailanthus } \\
\text { altissima }\end{array}$ & tree lean & 1 & $\begin{array}{l}43.660008^{\circ}, \\
-79.452722^{\circ}\end{array}$ & $\begin{array}{l}\text { Public (West } \\
\text { Toronto } \\
\text { Railpath) }\end{array}$ & New tree. \\
\hline $\begin{array}{l}\text { Tree of } \\
\text { Heaven }\end{array}$ & $\begin{array}{l}\text { Ailanthus } \\
\text { altissima }\end{array}$ & tree lean & 1 & $\begin{array}{l}43.660057^{\circ}, \\
-79.452785^{\circ}\end{array}$ & $\begin{array}{l}\text { Public (West } \\
\text { Toronto } \\
\text { Railpath) }\end{array}$ & New tree. \\
\hline
\end{tabular}




\begin{tabular}{|c|c|c|c|c|c|c|}
\hline $\begin{array}{l}\text { Tree of } \\
\text { Heaven }\end{array}$ & $\begin{array}{l}\text { Ailanthus } \\
\text { altissima }\end{array}$ & tree lean & 1 & $\begin{array}{l}43.660061^{\circ}, \\
-79.452754^{\circ}\end{array}$ & $\begin{array}{l}\text { Public (West } \\
\text { Toronto } \\
\text { Railpath) }\end{array}$ & New tree. \\
\hline $\begin{array}{l}\text { Tree of } \\
\text { Heaven }\end{array}$ & $\begin{array}{l}\text { Ailanthus } \\
\text { altissima }\end{array}$ & tree lean & 1 & $\begin{array}{l}43.660069^{\circ}, \\
-79.452797^{\circ}\end{array}$ & $\begin{array}{l}\text { Public (West } \\
\text { Toronto } \\
\text { Railpath) }\end{array}$ & New tree. \\
\hline $\begin{array}{l}\text { Tree of } \\
\text { Heaven }\end{array}$ & $\begin{array}{l}\text { Ailanthus } \\
\text { altissima }\end{array}$ & good condition & 0 & $\begin{array}{l}43.660102^{\circ}, \\
-79.452802^{\circ}\end{array}$ & $\begin{array}{l}\text { Public (West } \\
\text { Toronto } \\
\text { Railpath) }\end{array}$ & New tree. \\
\hline $\begin{array}{l}\text { Tree of } \\
\text { Heaven }\end{array}$ & $\begin{array}{l}\text { Ailanthus } \\
\text { altissima }\end{array}$ & good condition & 0 & $\begin{array}{l}43.660139^{\circ}, \\
-79.452873^{\circ}\end{array}$ & $\begin{array}{l}\text { Public (West } \\
\text { Toronto } \\
\text { Railpath) }\end{array}$ & New tree. \\
\hline $\begin{array}{l}\text { Tree of } \\
\text { Heaven }\end{array}$ & $\begin{array}{l}\text { Ailanthus } \\
\text { altissima }\end{array}$ & good condition & 0 & $\begin{array}{l}43.660152^{\circ}, \\
-79.452873^{\circ}\end{array}$ & $\begin{array}{l}\text { Public (West } \\
\text { Toronto } \\
\text { Railpath) }\end{array}$ & New tree. \\
\hline $\begin{array}{l}\text { Tree of } \\
\text { Heaven }\end{array}$ & $\begin{array}{l}\text { Ailanthus } \\
\text { altissima }\end{array}$ & good condition & 0 & $\begin{array}{l}43.660161^{\circ}, \\
-79.452710^{\circ}\end{array}$ & $\begin{array}{l}\text { Public (West } \\
\text { Toronto } \\
\text { Railpath) }\end{array}$ & New tree. \\
\hline $\begin{array}{l}\text { Tree of } \\
\text { Heaven }\end{array}$ & $\begin{array}{l}\text { Ailanthus } \\
\text { altissima }\end{array}$ & good condition & 0 & $\begin{array}{l}43.660164^{\circ}, \\
-79.452762^{\circ}\end{array}$ & $\begin{array}{l}\text { Public (West } \\
\text { Toronto } \\
\text { Railpath) }\end{array}$ & New tree. \\
\hline $\begin{array}{l}\text { Tree of } \\
\text { Heaven }\end{array}$ & $\begin{array}{l}\text { Ailanthus } \\
\text { altissima }\end{array}$ & good condition & 0 & $\begin{array}{l}43.660191^{\circ}, \\
-79.452897^{\circ}\end{array}$ & $\begin{array}{l}\text { Public (West } \\
\text { Toronto } \\
\text { Railpath) }\end{array}$ & New tree. \\
\hline $\begin{array}{l}\text { Tree of } \\
\text { Heaven }\end{array}$ & $\begin{array}{l}\text { Ailanthus } \\
\text { altissima }\end{array}$ & good condition & 0 & $\begin{array}{l}43.660222^{\circ}, \\
-79.452916^{\circ}\end{array}$ & $\begin{array}{l}\text { Public (West } \\
\text { Toronto } \\
\text { Railpath) }\end{array}$ & New tree. \\
\hline $\begin{array}{l}\text { Tree of } \\
\text { Heaven }\end{array}$ & $\begin{array}{l}\text { Ailanthus } \\
\text { altissima }\end{array}$ & good condition & 0 & $\begin{array}{l}43.660226^{\circ}, \\
-79.452825^{\circ}\end{array}$ & $\begin{array}{l}\text { Public (West } \\
\text { Toronto } \\
\text { Railpath) }\end{array}$ & New tree. \\
\hline $\begin{array}{l}\text { Tree of } \\
\text { Heaven }\end{array}$ & $\begin{array}{l}\text { Ailanthus } \\
\text { altissima }\end{array}$ & good condition & 0 & $\begin{array}{l}43.660233^{\circ}, \\
-79.452839^{\circ}\end{array}$ & $\begin{array}{l}\text { Public (West } \\
\text { Toronto } \\
\text { Railpath) }\end{array}$ & New tree. \\
\hline $\begin{array}{l}\text { Tree of } \\
\text { Heaven }\end{array}$ & $\begin{array}{l}\text { Ailanthus } \\
\text { altissima }\end{array}$ & good condition & 0 & $\begin{array}{l}43.660236^{\circ}, \\
-79.452781^{\circ}\end{array}$ & $\begin{array}{l}\text { Public (West } \\
\text { Toronto } \\
\text { Railpath) }\end{array}$ & New tree. \\
\hline $\begin{array}{l}\text { Tree of } \\
\text { Heaven }\end{array}$ & $\begin{array}{l}\text { Ailanthus } \\
\text { altissima }\end{array}$ & good condition & 0 & $\begin{array}{l}43.660245^{\circ}, \\
-79.452846^{\circ}\end{array}$ & $\begin{array}{l}\text { Public (West } \\
\text { Toronto } \\
\text { Railpath) }\end{array}$ & New tree. \\
\hline $\begin{array}{l}\text { Tree of } \\
\text { Heaven }\end{array}$ & $\begin{array}{l}\text { Ailanthus } \\
\text { altissima }\end{array}$ & good condition & 0 & $\begin{array}{l}43.660249^{\circ}, \\
-79.452958^{\circ}\end{array}$ & $\begin{array}{l}\text { Public (West } \\
\text { Toronto } \\
\text { Railpath) }\end{array}$ & New tree. \\
\hline $\begin{array}{l}\text { Tree of } \\
\text { Heaven }\end{array}$ & $\begin{array}{l}\text { Ailanthus } \\
\text { altissima }\end{array}$ & good condition & 0 & $\begin{array}{l}43.660251^{\circ}, \\
-79.452816^{\circ}\end{array}$ & $\begin{array}{l}\text { Public (West } \\
\text { Toronto } \\
\text { Railpath) }\end{array}$ & New tree. \\
\hline $\begin{array}{l}\text { Tree of } \\
\text { Heaven }\end{array}$ & $\begin{array}{l}\text { Ailanthus } \\
\text { altissima }\end{array}$ & good condition & 0 & $\begin{array}{l}43.660259^{\circ}, \\
-79.452969^{\circ}\end{array}$ & $\begin{array}{l}\text { Public (West } \\
\text { Toronto } \\
\text { Railpath) }\end{array}$ & New tree. \\
\hline $\begin{array}{l}\text { Tree of } \\
\text { Heaven }\end{array}$ & $\begin{array}{l}\text { Ailanthus } \\
\text { altissima }\end{array}$ & good condition & 0 & $\begin{array}{l}43.660264^{\circ}, \\
-79.452858^{\circ}\end{array}$ & $\begin{array}{l}\text { Public (West } \\
\text { Toronto } \\
\text { Railpath) }\end{array}$ & New tree. \\
\hline $\begin{array}{l}\text { Tree of } \\
\text { Heaven }\end{array}$ & $\begin{array}{l}\text { Ailanthus } \\
\text { altissima }\end{array}$ & good condition & 0 & $\begin{array}{l}43.660266^{\circ}, \\
-79.452867^{\circ}\end{array}$ & $\begin{array}{l}\text { Public (West } \\
\text { Toronto } \\
\text { Railpath) }\end{array}$ & New tree. \\
\hline $\begin{array}{l}\text { Tree of } \\
\text { Heaven }\end{array}$ & $\begin{array}{l}\text { Ailanthus } \\
\text { altissima }\end{array}$ & good condition & 0 & $\begin{array}{l}43.660276^{\circ}, \\
-79.452840^{\circ}\end{array}$ & $\begin{array}{l}\text { Public (West } \\
\text { Toronto } \\
\text { Railpath) }\end{array}$ & New tree. \\
\hline $\begin{array}{l}\text { Tree of } \\
\text { Heaven }\end{array}$ & $\begin{array}{l}\text { Ailanthus } \\
\text { altissima }\end{array}$ & good condition & 0 & $\begin{array}{l}43.660300^{\circ}, \\
-79.452869^{\circ}\end{array}$ & $\begin{array}{l}\text { Public (West } \\
\text { Toronto } \\
\text { Railpath) }\end{array}$ & New tree. \\
\hline $\begin{array}{l}\text { Tree of } \\
\text { Heaven }\end{array}$ & $\begin{array}{l}\text { Ailanthus } \\
\text { altissima }\end{array}$ & good condition & 0 & $\begin{array}{l}43.660300^{\circ}, \\
-79.452899^{\circ}\end{array}$ & $\begin{array}{l}\text { Public (West } \\
\text { Toronto } \\
\text { Railpath) }\end{array}$ & New tree. \\
\hline $\begin{array}{l}\text { Tree of } \\
\text { Heaven }\end{array}$ & $\begin{array}{l}\text { Ailanthus } \\
\text { altissima }\end{array}$ & good condition & 0 & $\begin{array}{l}43.660300^{\circ}, \\
-79.453020^{\circ}\end{array}$ & $\begin{array}{l}\text { Public (West } \\
\text { Toronto } \\
\text { Railpath) }\end{array}$ & New tree. \\
\hline $\begin{array}{l}\text { Tree of } \\
\text { Heaven }\end{array}$ & $\begin{array}{l}\text { Ailanthus } \\
\text { altissima }\end{array}$ & good condition & 0 & $\begin{array}{l}43.660314^{\circ}, \\
-79.452907^{\circ}\end{array}$ & $\begin{array}{l}\text { Public (West } \\
\text { Toronto } \\
\text { Railpath) }\end{array}$ & New tree. \\
\hline
\end{tabular}




\begin{tabular}{|c|c|c|c|c|c|c|}
\hline $\begin{array}{l}\text { Tree of } \\
\text { Heaven }\end{array}$ & $\begin{array}{l}\text { Ailanthus } \\
\text { altissima }\end{array}$ & good condition & 0 & $\begin{array}{l}43.660361^{\circ}, \\
-79.453089^{\circ}\end{array}$ & $\begin{array}{l}\text { Public (West } \\
\text { Toronto } \\
\text { Railpath) }\end{array}$ & New tree. \\
\hline $\begin{array}{l}\text { Tree of } \\
\text { Heaven }\end{array}$ & $\begin{array}{l}\text { Ailanthus } \\
\text { altissima }\end{array}$ & good condition & 0 & $\begin{array}{l}43.660376^{\circ}, \\
-79.453100^{\circ}\end{array}$ & $\begin{array}{l}\text { Public (West } \\
\text { Toronto } \\
\text { Railpath) }\end{array}$ & New tree. \\
\hline $\begin{array}{l}\text { Tree of } \\
\text { Heaven }\end{array}$ & $\begin{array}{l}\text { Ailanthus } \\
\text { altissima }\end{array}$ & good condition & 0 & $\begin{array}{l}43.660386^{\circ}, \\
-79.453120^{\circ}\end{array}$ & $\begin{array}{l}\text { Public (West } \\
\text { Toronto } \\
\text { Railpath) }\end{array}$ & New tree. \\
\hline $\begin{array}{l}\text { Tree of } \\
\text { Heaven }\end{array}$ & $\begin{array}{l}\text { Ailanthus } \\
\text { altissima }\end{array}$ & good condition & 0 & $\begin{array}{l}43.660125^{\circ}, \\
-79.452712^{\circ}\end{array}$ & $\begin{array}{l}\text { Public (West } \\
\text { Toronto } \\
\text { Railpath) }\end{array}$ & New tree. Near construction. \\
\hline $\begin{array}{l}\text { Tree of } \\
\text { Heaven }\end{array}$ & $\begin{array}{l}\text { Ailanthus } \\
\text { altissima }\end{array}$ & good condition & 0 & $\begin{array}{l}43.660233^{\circ} \\
-79.452836^{\circ}\end{array}$ & $\begin{array}{l}\text { Public (West } \\
\text { Toronto } \\
\text { Railpath) }\end{array}$ & New tree. Near construction. \\
\hline $\begin{array}{l}\text { Tree of } \\
\text { Heaven }\end{array}$ & $\begin{array}{l}\text { Ailanthus } \\
\text { altissima }\end{array}$ & good condition & 0 & $\begin{array}{l}43.660248^{\circ}, \\
-79.452813^{\circ}\end{array}$ & $\begin{array}{l}\text { Public (West } \\
\text { Toronto } \\
\text { Railpath) }\end{array}$ & New tree. Near construction. \\
\hline $\begin{array}{l}\text { Tree of } \\
\text { Heaven }\end{array}$ & $\begin{array}{l}\text { Ailanthus } \\
\text { altissima }\end{array}$ & good condition & 0 & $\begin{array}{l}43.660255^{\circ}, \\
-79.452820^{\circ}\end{array}$ & $\begin{array}{l}\text { Public (West } \\
\text { Toronto } \\
\text { Railpath) }\end{array}$ & New tree. Near construction. \\
\hline $\begin{array}{l}\text { Tree of } \\
\text { Heaven }\end{array}$ & $\begin{array}{l}\text { Ailanthus } \\
\text { altissima }\end{array}$ & good condition & 0 & $\begin{array}{l}43.660257^{\circ}, \\
-79.452855^{\circ}\end{array}$ & $\begin{array}{l}\text { Public (West } \\
\text { Toronto } \\
\text { Railpath) }\end{array}$ & New tree. Near construction. \\
\hline $\begin{array}{l}\text { Tree of } \\
\text { Heaven }\end{array}$ & $\begin{array}{l}\text { Ailanthus } \\
\text { altissima }\end{array}$ & good condition & 0 & $\begin{array}{l}43.660266^{\circ}, \\
-79.452801^{\circ}\end{array}$ & $\begin{array}{l}\text { Public (West } \\
\text { Toronto } \\
\text { Railpath) }\end{array}$ & New tree. Near construction. \\
\hline $\begin{array}{l}\text { Tree of } \\
\text { Heaven }\end{array}$ & $\begin{array}{l}\text { Ailanthus } \\
\text { altissima }\end{array}$ & good condition & 0 & $\begin{array}{l}43.660268^{\circ}, \\
-79.452790^{\circ}\end{array}$ & $\begin{array}{l}\text { Public (West } \\
\text { Toronto } \\
\text { Railpath) }\end{array}$ & New tree. Near construction. \\
\hline $\begin{array}{l}\text { Tree of } \\
\text { Heaven }\end{array}$ & $\begin{array}{l}\text { Ailanthus } \\
\text { altissima }\end{array}$ & good condition & 0 & $\begin{array}{l}43.660296^{\circ}, \\
-79.452875^{\circ}\end{array}$ & $\begin{array}{l}\text { Public (West } \\
\text { Toronto } \\
\text { Railpath) }\end{array}$ & New tree. Near construction. \\
\hline $\begin{array}{l}\text { Tree of } \\
\text { Heaven }\end{array}$ & $\begin{array}{l}\text { Ailanthus } \\
\text { altissima }\end{array}$ & good condition & 0 & $\begin{array}{l}43.660301^{\circ}, \\
-79.452911^{\circ}\end{array}$ & $\begin{array}{l}\text { Public (West } \\
\text { Toronto } \\
\text { Railpath) }\end{array}$ & New tree. Near construction. \\
\hline $\begin{array}{l}\text { Tree of } \\
\text { Heaven }\end{array}$ & $\begin{array}{l}\text { Ailanthus } \\
\text { altissima }\end{array}$ & good condition & 0 & $\begin{array}{l}43.660314^{\circ}, \\
-79.452932^{\circ}\end{array}$ & $\begin{array}{l}\text { Public (West } \\
\text { Toronto } \\
\text { Railpath) }\end{array}$ & New tree. Near construction. \\
\hline $\begin{array}{l}\text { Tree of } \\
\text { Heaven }\end{array}$ & $\begin{array}{l}\text { Ailanthus } \\
\text { altissima }\end{array}$ & good condition & 0 & $\begin{array}{l}43.660329^{\circ}, \\
-79.452899^{\circ}\end{array}$ & $\begin{array}{l}\text { Public (West } \\
\text { Toronto } \\
\text { Railpath) }\end{array}$ & New tree. Near construction. \\
\hline $\begin{array}{l}\text { Tree of } \\
\text { Heaven }\end{array}$ & $\begin{array}{l}\text { Ailanthus } \\
\text { altissima }\end{array}$ & good condition & 0 & $\begin{array}{l}43.660330^{\circ}, \\
-79.452836^{\circ}\end{array}$ & $\begin{array}{l}\text { Public (West } \\
\text { Toronto } \\
\text { Railpath) }\end{array}$ & New tree. Near construction. \\
\hline $\begin{array}{l}\text { Tree of } \\
\text { Heaven }\end{array}$ & $\begin{array}{l}\text { Ailanthus } \\
\text { altissima }\end{array}$ & good condition & 0 & $\begin{array}{l}43.660331^{\circ}, \\
-79.452904^{\circ}\end{array}$ & $\begin{array}{l}\text { Public (West } \\
\text { Toronto } \\
\text { Railpath) }\end{array}$ & New tree. Near construction. \\
\hline $\begin{array}{l}\text { Tree of } \\
\text { Heaven }\end{array}$ & $\begin{array}{l}\text { Ailanthus } \\
\text { altissima }\end{array}$ & good condition & 0 & $\begin{array}{l}43.660336^{\circ}, \\
-79.452841^{\circ}\end{array}$ & $\begin{array}{l}\text { Public (West } \\
\text { Toronto } \\
\text { Railpath) }\end{array}$ & New tree. Near construction. \\
\hline $\begin{array}{l}\text { Tree of } \\
\text { Heaven }\end{array}$ & $\begin{array}{l}\text { Ailanthus } \\
\text { altissima }\end{array}$ & good condition & 0 & $\begin{array}{l}43.660336^{\circ}, \\
-79.452842^{\circ}\end{array}$ & $\begin{array}{l}\text { Public (West } \\
\text { Toronto } \\
\text { Railpath) }\end{array}$ & New tree. Near construction. \\
\hline $\begin{array}{l}\text { Tree of } \\
\text { Heaven }\end{array}$ & $\begin{array}{l}\text { Ailanthus } \\
\text { altissima }\end{array}$ & good condition & 0 & $\begin{array}{l}43.659542^{\circ}, \\
-79.452159^{\circ}\end{array}$ & $\begin{array}{l}\text { Public (West } \\
\text { Toronto } \\
\text { Railpath) }\end{array}$ & \\
\hline $\begin{array}{l}\text { Tree of } \\
\text { Heaven }\end{array}$ & $\begin{array}{l}\text { Ailanthus } \\
\text { altissima }\end{array}$ & good condition & 0 & $\begin{array}{l}43.659597^{\circ}, \\
-79.452214^{\circ}\end{array}$ & $\begin{array}{l}\text { Public (West } \\
\text { Toronto } \\
\text { Railpath) }\end{array}$ & \\
\hline $\begin{array}{l}\text { Tree of } \\
\text { Heaven }\end{array}$ & $\begin{array}{l}\text { Ailanthus } \\
\text { altissima }\end{array}$ & good condition & 0 & $\begin{array}{l}43.659853^{\circ}, \\
-79.452564^{\circ}\end{array}$ & $\begin{array}{l}\text { Public (West } \\
\text { Toronto } \\
\text { Railpath) }\end{array}$ & \\
\hline $\begin{array}{l}\text { Tree of } \\
\text { Heaven }\end{array}$ & $\begin{array}{l}\text { Ailanthus } \\
\text { altissima }\end{array}$ & good condition & 0 & $\begin{array}{l}43.659897^{\circ}, \\
-79.452604^{\circ}\end{array}$ & $\begin{array}{l}\text { Public (West } \\
\text { Toronto } \\
\text { Railpath) }\end{array}$ & \\
\hline $\begin{array}{l}\text { Tree of } \\
\text { Heaven }\end{array}$ & $\begin{array}{l}\text { Ailanthus } \\
\text { altissima }\end{array}$ & good condition & 0 & $\begin{array}{l}43.659922^{\circ}, \\
-79.452631^{\circ}\end{array}$ & $\begin{array}{l}\text { Public (West } \\
\text { Toronto } \\
\text { Railpath) }\end{array}$ & \\
\hline
\end{tabular}




\begin{tabular}{|c|c|c|c|c|c|c|}
\hline $\begin{array}{l}\text { Tree of } \\
\text { Heaven }\end{array}$ & $\begin{array}{l}\text { Ailanthus } \\
\text { altissima }\end{array}$ & good condition & 0 & $\begin{array}{l}43.659941^{\circ}, \\
-79.452652^{\circ}\end{array}$ & $\begin{array}{l}\text { Public (West } \\
\text { Toronto } \\
\text { Railpath) }\end{array}$ & \\
\hline $\begin{array}{l}\text { Tree of } \\
\text { Heaven }\end{array}$ & $\begin{array}{l}\text { Ailanthus } \\
\text { altissima }\end{array}$ & good condition & 0 & $\begin{array}{l}43.659972^{\circ}, \\
-79.452675^{\circ}\end{array}$ & $\begin{array}{l}\text { Public (West } \\
\text { Toronto } \\
\text { Railpath) }\end{array}$ & \\
\hline $\begin{array}{l}\text { Tree of } \\
\text { Heaven }\end{array}$ & $\begin{array}{l}\text { Ailanthus } \\
\text { altissima }\end{array}$ & good condition & 0 & $\begin{array}{l}43.659991^{\circ}, \\
-79.452687^{\circ}\end{array}$ & $\begin{array}{l}\text { Public (West } \\
\text { Toronto } \\
\text { Railpath) }\end{array}$ & \\
\hline $\begin{array}{l}\text { Tree of } \\
\text { Heaven }\end{array}$ & $\begin{array}{l}\text { Ailanthus } \\
\text { altissima }\end{array}$ & dead/broken branches & 2 & $\begin{array}{l}43.660011^{\circ}, \\
-79.452601^{\circ}\end{array}$ & $\begin{array}{l}\text { Public (West } \\
\text { Toronto } \\
\text { Railpath) }\end{array}$ & \\
\hline $\begin{array}{l}\text { Tree of } \\
\text { Heaven }\end{array}$ & $\begin{array}{l}\text { Ailanthus } \\
\text { altissima }\end{array}$ & good condition & 0 & $\begin{array}{l}43.660027^{\circ}, \\
-79.452722^{\circ}\end{array}$ & $\begin{array}{l}\text { Public (West } \\
\text { Toronto } \\
\text { Railpath) }\end{array}$ & \\
\hline $\begin{array}{l}\text { Tree of } \\
\text { Heaven }\end{array}$ & $\begin{array}{l}\text { Ailanthus } \\
\text { altissima }\end{array}$ & good condition & 0 & $\begin{array}{l}43.660053^{\circ} \\
-79.452744^{\circ}\end{array}$ & $\begin{array}{l}\text { Public (West } \\
\text { Toronto } \\
\text { Railpath) }\end{array}$ & \\
\hline $\begin{array}{l}\text { Tree of } \\
\text { Heaven }\end{array}$ & $\begin{array}{l}\text { Ailanthus } \\
\text { altissima }\end{array}$ & tree lean & 1 & $\begin{array}{l}43.660116^{\circ}, \\
-79.452709^{\circ}\end{array}$ & $\begin{array}{l}\text { Public (West } \\
\text { Toronto } \\
\text { Railpath) }\end{array}$ & \\
\hline $\begin{array}{l}\text { Trembling } \\
\text { Aspen }\end{array}$ & $\begin{array}{l}\text { Populus } \\
\text { tremuloides }\end{array}$ & peeling bark, tree lean & 2 & $\begin{array}{l}43.659009^{\circ}, \\
-79.451648^{\circ}\end{array}$ & $\begin{array}{l}\text { Public (West } \\
\text { Toronto } \\
\text { Railpath) }\end{array}$ & New tree. \\
\hline $\begin{array}{l}\text { Trembling } \\
\text { Aspen }\end{array}$ & $\begin{array}{l}\text { Populus } \\
\text { tremuloides }\end{array}$ & peeling bark & 1 & $\begin{array}{l}43.659012^{\circ} \\
-79.451631^{\circ}\end{array}$ & $\begin{array}{l}\text { Public (West } \\
\text { Toronto } \\
\text { Railpath) }\end{array}$ & New tree. \\
\hline $\begin{array}{l}\text { Trembling } \\
\text { Aspen }\end{array}$ & $\begin{array}{l}\text { Populus } \\
\text { tremuloides }\end{array}$ & peeling bark, tree lean & 2 & $\begin{array}{l}43.659020^{\circ} \\
-79.451636^{\circ}\end{array}$ & $\begin{array}{l}\text { Public (West } \\
\text { Toronto } \\
\text { Railpath) }\end{array}$ & New tree. \\
\hline $\begin{array}{l}\text { Trembling } \\
\text { Aspen }\end{array}$ & $\begin{array}{l}\text { Populus } \\
\text { tremuloides }\end{array}$ & peeling bark, tree lean & 2 & $\begin{array}{l}43.659025^{\circ} \\
-79.451661^{\circ}\end{array}$ & $\begin{array}{l}\text { Public (West } \\
\text { Toronto } \\
\text { Railpath) }\end{array}$ & New tree. \\
\hline $\begin{array}{l}\text { Trembling } \\
\text { Aspen }\end{array}$ & $\begin{array}{l}\text { Populus } \\
\text { tremuloides }\end{array}$ & peeling bark & 1 & $\begin{array}{l}43.659035^{\circ}, \\
-79.451654^{\circ}\end{array}$ & $\begin{array}{l}\text { Public (West } \\
\text { Toronto } \\
\text { Railpath) }\end{array}$ & New tree. \\
\hline $\begin{array}{l}\text { Trembling } \\
\text { Aspen }\end{array}$ & $\begin{array}{l}\text { Populus } \\
\text { tremuloides }\end{array}$ & peeling bark & 1 & $\begin{array}{l}43.659039^{\circ}, \\
-79.451649^{\circ}\end{array}$ & $\begin{array}{l}\text { Public (West } \\
\text { Toronto } \\
\text { Railpath) }\end{array}$ & New tree. \\
\hline $\begin{array}{l}\text { White } \\
\text { Mulberry }\end{array}$ & Morus alba & good condition & 0 & $\begin{array}{l}43.657938^{\circ}, \\
-79.450618^{\circ}\end{array}$ & $\begin{array}{l}\text { Public (West } \\
\text { Toronto } \\
\text { Railpath) }\end{array}$ & New tree. \\
\hline $\begin{array}{l}\text { White } \\
\text { Mulberry }\end{array}$ & Morus alba & good condition & 0 & $\begin{array}{l}43.658298^{\circ} \\
-79.450926^{\circ}\end{array}$ & $\begin{array}{l}\text { Public (West } \\
\text { Toronto } \\
\text { Railpath) }\end{array}$ & New tree. \\
\hline $\begin{array}{l}\text { White } \\
\text { Mulberry }\end{array}$ & Morus alba & dead/broken branches & 2 & $\begin{array}{l}43.658843^{\circ}, \\
-79.451493^{\circ}\end{array}$ & $\begin{array}{l}\text { Public (West } \\
\text { Toronto } \\
\text { Railpath) }\end{array}$ & New tree. \\
\hline $\begin{array}{l}\text { White } \\
\text { Mulberry }\end{array}$ & Morus alba & dead/broken branches & 2 & $\begin{array}{l}43.658859^{\circ}, \\
-79.451502^{\circ}\end{array}$ & $\begin{array}{l}\text { Public (West } \\
\text { Toronto } \\
\text { Railpath) }\end{array}$ & New tree. \\
\hline $\begin{array}{l}\text { White } \\
\text { Mulberry }\end{array}$ & Morus alba & $\begin{array}{l}\text { tree lean, dead/broken } \\
\text { branches, }\end{array}$ & 3 & $\begin{array}{l}43.658860^{\circ}, \\
-79.451507^{\circ}\end{array}$ & $\begin{array}{l}\text { Public (West } \\
\text { Toronto } \\
\text { Railpath) }\end{array}$ & New tree. \\
\hline $\begin{array}{l}\text { White } \\
\text { Mulberry }\end{array}$ & Morus alba & tree lean & 1 & $\begin{array}{l}43.658952^{\circ} \\
-79.451612^{\circ}\end{array}$ & $\begin{array}{l}\text { Public (West } \\
\text { Toronto } \\
\text { Railpath) }\end{array}$ & New tree. \\
\hline $\begin{array}{l}\text { White } \\
\text { Mulberry }\end{array}$ & Morus alba & good condition & 0 & $\begin{array}{l}43.659849^{\circ} \\
-79.452466^{\circ}\end{array}$ & $\begin{array}{l}\text { Public (West } \\
\text { Toronto } \\
\text { Railpath) }\end{array}$ & New tree. \\
\hline
\end{tabular}




\section{Appendix 2: Number and Species of Trees in 2007 and 2016}

Table A2: Number trees and species in 2007 and 2016.

\begin{tabular}{|c|c|c|}
\hline Species & Number of Trees 2007 & Number of Trees 2016 \\
\hline American elm & 6 & 29 \\
\hline Apricot Tree & 2 & 2 \\
\hline Austrian Pine & 11 & 7 \\
\hline Balsam fir & 1 & 1 \\
\hline Balsam poplar & 1 & 0 \\
\hline Basswood & 8 & 4 \\
\hline Big leaf maple & 0 & 1 \\
\hline Black locust & 5 & 16 \\
\hline Black maple & 10 & 10 \\
\hline Blue Spruce & 9 & 10 \\
\hline Callery pear tree & 11 & 11 \\
\hline Canada plum & 2 & 1 \\
\hline Cherry plum tree & 39 & 27 \\
\hline Chinese elm & 12 & 56 \\
\hline Choke cherry & 15 & 11 \\
\hline Common Apple & 6 & 2 \\
\hline Common lilac & 7 & 0 \\
\hline Common pawpaw & 0 & 1 \\
\hline Corkscrew willow & 1 & 1 \\
\hline Douglas fir & 8 & 10 \\
\hline Eastern white cedar & 51 & 146 \\
\hline Eastern white pine & 1 & 2 \\
\hline English oak & 8 & 19 \\
\hline European beech & 1 & 7 \\
\hline European mountain ash & 5 & 0 \\
\hline Freeman maple & 16 & 21 \\
\hline Ginkgo & 5 & 16 \\
\hline Green ash & 58 & 22 \\
\hline Hackberry & 2 & 0 \\
\hline Honey locust & 20 & 35 \\
\hline Japanese cherry & 0 & 1 \\
\hline Japanese katsura & 0 & 4 \\
\hline Japanese maple & 7 & 11 \\
\hline Kentucky coffee tree & 0 & 8 \\
\hline Kentucky yellowwood & 0 & 4 \\
\hline Little leaf linden & 19 & 41 \\
\hline London plane tree & 0 & 8 \\
\hline
\end{tabular}




\begin{tabular}{|c|c|c|}
\hline Manitoba maple & 117 & 51 \\
\hline Northern catalpa & 0 & 1 \\
\hline Norway maple & 82 & 78 \\
\hline Norway spruce & 7 & 16 \\
\hline Ohio buckeye & 0 & 5 \\
\hline Paper birch & 9 & 21 \\
\hline Peach tree & 2 & 2 \\
\hline Red maple & 1 & 3 \\
\hline Red mulberry & 2 & 2 \\
\hline Red oak & 13 & 9 \\
\hline Red spruce & 2 & 2 \\
\hline Redbud & 16 & 16 \\
\hline Russian olive & 1 & 0 \\
\hline Saucer magnolia & 2 & 0 \\
\hline Scotch elm & 1 & 1 \\
\hline Scots pine & 1 & 1 \\
\hline Siberian elm & 22 & 33 \\
\hline Silver maple & 15 & 15 \\
\hline Sugar maple & 0 & 15 \\
\hline Swedish white beam & 1 & 1 \\
\hline Sweet gum & 0 & 1 \\
\hline Tamarack & 7 & 7 \\
\hline Tree of heaven & 115 & 119 \\
\hline Trembling aspen & 23 & 14 \\
\hline Tulip tree & 0 & 3 \\
\hline Weeping cypress & 2 & 3 \\
\hline White mulberry & 10 & 18 \\
\hline White oak & 2 & 0 \\
\hline White spruce & 0 & 19 \\
\hline Grand Total & 800 & 1001 \\
\hline
\end{tabular}




\title{
Appendix 3: Questionnaire, Introductory Materials, and Results
}

\author{
Appendix 3.1: Questionnaire Recruitment Script
}

\section{Assessing Tree Health and Species in the Gentrifying Neighborhood of the Junction Triangle in Toronto, Ontario.}

Hello,

My name is Ritam Sen and I am a graduate student at Ryerson University in the Environmental Applied Science and Management program. I am contacting you to see if you might be interested in participating in a research study that I am conducting. This research is being done as a part of my Master's thesis paper and my research supervisor's name is Dr. Michal Bardecki.

The focus of this research is on neighbourhood redevelopment and urban trees. The study is centered around gaining an understanding of how species and health of trees has changed over time due to the many structural changes that have occurred in this neighbourhood.

To participate, you need to be over the age of 18 and the primary decision maker in your household. Both renters and owners of homes are qualified to participate. If you agree to volunteer, you will be asked to complete a 24 question multiple choice questionnaire

The questionnaire asks about your general feelings towards trees, tree species, and tree care, as well as your general feelings towards housing renovations and the redevelopments currently taking place within the neighbourhood. There are a few demographic questions as well, such as age, and ownership status of your current home, but I will not be collected any invasive information such as your income level, profession, etc.

The questionnaire should take no more than 5 minutes to complete and if there are any questions that you do not want to answer, feel free to skip them. Your participation is completely voluntary and you do not need to participate in the research if you do not wish to.

Along with the questionnaire, there is a consent agreement which will describe in detail what your participation means, confidentiality, potential risks and benefits, and the voluntary nature of this research. Please take the time to read through both items.

If you have any questions about this research and/or your participation, please feel free to email me at ritam.sen@ryerson.ca. 
This research has been reviewed and approved by the Ryerson University Ethics Board.

Appendix 3.2: Questionnaire Consent Form

\section{Ryerson University Consent Agreement}

You are being invited to participate in a research study. Please read this consent agreement so that you understand what your participation will involve. Before you consent to participate, please ask any questions to be sure you understand what your participation will involve.

\section{Assessing Tree Health and Species in the Gentrifying Neighbourhood of the Junction Triangle in Toronto, Ontario.}

\section{INVESTIGATORS:}

This research is being conducted by Ritam Sen and Dr. Michal Bardecki, from the Environmental Applied Science and Management Program at Ryerson University

\section{PURPOSE OF THE STUDY:}

The purpose of the study is to determine how housing renovations and redevelopment has affected the health and species of trees in the Junction Triangle. Currently, there is a lack understanding on how trees are affected when construction and renovations take place in a neighbourhood, and the goal of this research is to determine how urban trees are affected when these changes occur. 150 residents of the neighbourhood will be asked to participate in this study, and the results will contribute to the completion of a graduate thesis paper.

\section{WHAT PARTICIPATION MEANS:}

- If you volunteer to participate in this study, you will be asked to complete and return a questionnaire with 24 questions, as well as this consent agreement.

- This study will be recruiting 150 participants from the Junction Triangle neighbourhood. 
- The questionnaire will be handed out on a door to door basis, and should take no more than 5 minutes to complete in the comfort of your own home.

- The questionnaire will ask you about your general feelings towards trees in the neighbourhood, species and maintenance, as well as your general feelings towards the redevelopments and renovations on homes in within the neighbourhood.

\section{- Sample Questions:}

1) Do you think that trees are a valuable and important addition to a residential neighborhood?

2) Generally, how do you feel about the housing redevelopments taking place within the neighborhood?

3) Have you noticed a loss of trees due to the recent redevelopments in your neighborhood?

- Demographic information such as age, time living in the neighbourhood and ownership status of your current home will be collected. However, this data will not be singled out in the graduate thesis as the purpose of collecting this type of information is to look for overall patterns across all the completed questionnaires.

- There are no incentives, financial or otherwise, being provided for the completion of the questionnaires.

\section{THE POTENTIAL RISKS AND BENEFITS OF THIS RESEARCH:}

The potential risks of this study are extremely low. There are no physical, psychological, financial, or legal risks involved with this research. The only form of risk that may be associated with this research is social risk. Social risk is described as risk with the potential for the participant to be embarrassed or exposed due to their opinions. Please refer to the two following sections (Confidentiality and Voluntary Participation) on how this type of risk will be mitigated.

This research is important because currently there are not many scientific studies available describing the changes trees experience within a redeveloping neighbourhood. Much of the existing science focuses on urban redevelopment and how it has positively or negatively effected humans, but the environment needs to be taken into consideration as well. One step toward a better understanding of the urban environment is by studying trees in a neighbourhood that is changing constantly and consistently. This research study will address an area of knowledge that has yet to be fully understood.

\section{CONFIDENTIALITY:}

Participation in this study is confidential. As such, the potential for social risk is low. No names, home addresses, postal codes, e-mail addresses or phone numbers will be collected or recorded during this research. The recruitment of participants for this study is being done on a door to door basis and you will not be anonymous as your name and home address will be known to me. However, this information will not be documented or included in the analysis of this research or 
the final paper. Any information that you provide me with will not be released into the public and no direct quotations from you will be used in the final paper. All of the questionnaires are hard copy. Once all the responses are collected, the data will be amassed together, then input onto a computer so that overall trends and patterns throughout the neighbourhood can be analyzed in the final paper. No individual responses will be singled out in the final paper or input onto the computer.

The questionnaire and this consent agreement will be collected and stored in two separate locked boxes so they may not be connected to each other in any way. Only myself and my research supervisor (Dr. Michal Bardeck) will have access to these locked boxes. The hard copy data will be stored until the completion and successful defense of the graduate thesis paper. Upon completion, the hard copy data will be shredded and recycled.

\section{VOLUNTARY PARTICIPATION:}

Participation in this study is completely voluntary. You have no obligation to complete and return the questionnaire and consent agreement. If you should feel the need, you may decline to complete and return the questionnaire and consent agreement at any time. If there are any questions that should make you feel uncomfortable, or you simply wish to not answer, feel free to skip them. Your choice of whether or not to participate will not influence your current or future relations with Ryerson University.

\section{QUESTIONS ABOUT THE STUDY:}

If you have any questions about the research now, please ask. If you have question later regarding this study, please feel free to contact me by email at ritam.sen@ ryerson.ca, or my research supervisor Dr. Michal Bardecki at bardecki@geography.ryerson.ca.

This study has been reviewed and approved by the Ryerson Research Ethics Board. If you have any comments or concerns regarding your rights as a participant in this study, please contact:

Ryerson Research Ethics Board

c/o Office of the Vice President, Research and Innovation

Ryerson University

350 Victoria Street

Toronto, ON M5B 2K3

416-979-5042

rebchair@ryerson.ca 
Appendix 3.3: Tree and Gentrification Questionnaire

\section{Assessing Tree Health and Species in the Neighborhood of the Junction Triangle in Toronto, Ontario.}

1. Are you the primary resident of your home?
a) Yes
b) No

2. Generally, how do you feel about the redevelopments taking place within your neighbourhood?
a) Strongly like
b) Somewhat like
c) Neither like nor dislike
d) Somewhat dislike
e) Strongly dislike

3. If you've answered 'dislike' to the previous question, then why? (You may select more than one)
a) The construction is noisy
b) The construction causes in too much traffic
c) The construction does not look good
d) The new buildings do not look good
e) The new lofts/condominiums are decreasing the value of my home
f) Too many new people are moving into the neighbourhood
g) Other (Please specify):

4. If you've answered 'like' to question 2, then why?
a) It brings many new people into the neighbourhood
b) The general attractiveness of the neighbourhood has increased
c) There are more trees in the neighbourhood
d) Other (Please specify):

5. Do you live in a house that has been renovated within the last 10 years?
a) Yes, I have had renovations conducted on the home
b) Yes, a previous resident has conducted renovations
c) Yes, the owner of the home has conducted renovations on the home
d) No, I do not live in a renovated home
e) Unsure 
6. If the answer to the previous question is 'yes', then was planting or removing one or more trees a part of those renovations?

a) Yes, one or more trees were planted on my property

b) Yes, one or more trees were removed from my property

c) Yes, trees were both removed and planted on my property

d) No, nothing was changed about the trees on my property

e) I have no trees on my property

f) Unsure

7. If one or more trees is planted on your property, whose decision was it to plant the tree $(\mathrm{s})$ ?
a) It was my, or my family's, decision to plant the tree(s)
b) It was the City's decision to plant the tree(s)
c) I have no tree(s) on my property
d) Unsure

8. Are you planning on adding any new trees on your property?
a) Yes, I plan to add new trees in the future
b) No, I do not plan to add new trees
c) I will let the City decide what is best
d) Unsure

9. Generally, the trees in your neighbourhood are well taken care of
a) Strongly agree
b) Somewhat agree
c) Neither agree nor disagree
d) Somewhat disagree
e) Strongly disagree

10. Do you think that trees are a valuable and important addition to a residential neighbourhood?
a) Extremely important
b) Somewhat important
c) Neutral
d) Somewhat unimportant
e) Extremely unimportant

11. A well treed neighbourhood provides environmental benefits
a) Strongly agree
b) Somewhat agree
c) Neither agree nor disagree
d) Somewhat disagree
e) Strongly disagree 
12. A well treed neighbourhood improves the value of homes in the neighbourhood
a) Strongly agree
b) Somewhat agree
c) Neither agree or disagree
d) Somewhat disagree
e) Strongly disagree

13. Do you believe that the presence of trees in your neighbourhood specifically has improved its quality?
a) Extremely improved
b) Somewhat improved
c) Neither improved nor unimproved
d) Somewhat unimproved
e) Strongly unimproved

14. Which of these are the most important benefits of trees to you? (You may select more than one)
a) Aesthetics (ie. Providing beauty and serenity)
b) Increased housing value
c) Provision of shade
d) Reducing cooling and heating costs
e) Improving air and water quality
f) Providing habitats for wildlife
g) Other (please specify):

15. Do you actively do anything to maintain the health of the tree(s) outside your home? (You may select more than one):
a) I prune/trim the branches on my tree(s)
b) I add mulch to the soil around my tree(s)
c) I add fertilizer to the soil around my tree(s)
d) I water my tree(s)
e) I let the City of Toronto take care of my tree(s)
f) I do not actively maintain my tree(s)
g) I do not have a tree on my property
h) Other (please specify):

16. What is your opinion of the tree(s) outside your home? (You may select more than one):
a) I do not want a tree on my property
b) There are one or more trees I do not like
c) I would like a different, or additional, tree
d) I am satisfied with the tree(s) outside my home
e) I have no feelings towards the tree(s) outside my home
f) There is no tree(s) outside my home 
17. If you've answered that you would like a different tree to the previous question, then why? (You may select more than one):
a) The tree(s) is too large
b) The tree(s) is too small
c) The tree(s) is not attractive to me
d) The condition of the tree(s) is poor
e) Other (please specify):

18. If you'd like a different, or new, tree, then which species?
a) I would like
b) I do not want a different or new tree on my property
c) Unsure

19. Have you noticed a loss of trees due to the recent redevelopments in your neighbourhood?
a) A large number of trees have been removed
b) A small number of trees have been removed
c) I am unsure of the number of trees that have been removed

20. Have you noticed any new trees being planted in your neighbourhood?
a) A large number of new trees have been planted
b) A small number of new trees planted
c) I am unsure of the number of new trees that have been planted

21. As homes are being redeveloped, have you noticed more attractive trees being planted?
a) A large number of attractive trees have been planted
b) A small number of attractive trees have been planted
c) I am unsure of the number of attractive trees that have been planted
d) I do not believe that trees are attractive

22. Which age group do you fall under?
a) Under 20
b) $21-30$
c) $31-40$
d) $41-50$
e) $51-60$
f) $61+$
g) I do not wish to disclose this information

23. Did you move into your home prior to, or after 2007 ?
a) Prior to 2007
b) After 2007
c) $\ln 2007$
d) I do not wish to disclose this information 
24. Do you rent or own the home in which you currently reside?
a) Rent
b) Own
c) I do not wish to disclose this information

\section{Appendix 3.4 Questionnaire Results:}

Table A3 the results of the questionnaire. Questions are numbered 1 through 24 on the left most column, while the responses are lettered a through $\mathrm{h}$ on the top row. The numbers in the other cells show the number of times that the response was selected. Percentages were not used as many respondents selected more than one response for some questions, which may yield more than $100 \%$ in some cases.

Table A3: Full results of the questionnaire.

\begin{tabular}{|c|c|c|c|c|c|c|c|}
\hline Question Number & a) & b) & c) & d) & e) & f) & g) \\
\hline 1 & 53 & & & & & & \\
\hline 2 & 3 & 3 & 10 & 27 & 10 & & \\
\hline 3 & 24 & 34 & 17 & 5 & 20 & 4 & 2 \\
\hline 4 & 3 & 5 & 7 & & & & \\
\hline 5 & 25 & 10 & 6 & 13 & & & \\
\hline 6 & 5 & 4 & 11 & 10 & 4 & 9 & \\
\hline 7 & 14 & 40 & 4 & & & & \\
\hline 8 & 16 & 17 & 25 & 4 & & & \\
\hline 9 & 13 & 21 & 14 & 6 & & & \\
\hline 10 & 22 & 18 & 7 & 5 & & & \\
\hline 11 & 29 & 13 & 8 & 1 & & & \\
\hline 12 & 20 & 19 & 11 & 4 & & & \\
\hline 13 & 21 & 18 & 12 & 2 & & & \\
\hline 14 & 40 & 26 & 21 & 15 & 25 & 22 & 2 \\
\hline 15 & 15 & 8 & 11 & 40 & 40 & 4 & 3 \\
\hline 16 & 6 & 22 & 14 & 12 & 1 & & \\
\hline 17 & 2 & & 3 & 12 & 1 & & \\
\hline 18 & 15 & 10 & 9 & & & & \\
\hline 19 & & 24 & 30 & & & & \\
\hline 20 & 1 & 25 & 27 & & & & \\
\hline
\end{tabular}




\begin{tabular}{|l|l|l|l|l|l|l|l|}
\hline $\mathbf{2 1}$ & & 19 & 28 & 6 & & & \\
\hline $\mathbf{2 2}$ & & 9 & 21 & 6 & 15 & 2 & \\
\hline $\mathbf{2 3}$ & 35 & 18 & & & & & \\
\hline $\mathbf{2 4}$ & 10 & 43 & & & & & \\
\hline
\end{tabular}




\section{Appendix 4: Mann-Whitney U Test Results}

Appendix 4.1: Public Land Trees vs Trees in front of Homes

Table A4.1: Mann-Whitney U test between trees on public land and in front of housing.

\begin{tabular}{|c|c|c|c|}
\hline \multicolumn{4}{|c|}{ Ranks } \\
\hline Location & $N$ & Mean Rank & $\begin{array}{l}\text { Sum of } \\
\text { Ranks }\end{array}$ \\
\hline In front of homes & 627 & 464.21 & 291057.50 \\
\hline Public & 374 & 562.68 & 210443.50 \\
\hline Total & 1001 & & \\
\hline
\end{tabular}

Test Statistics ${ }^{\mathrm{a}}$

\begin{tabular}{lr} 
& \multicolumn{1}{c}{ Rating } \\
\hline Mann-Whitney U & 94179.500 \\
\hline Wilcoxon W & 291057.500 \\
\hline Z & -5.674 \\
\hline Asymp. Sig. (2-tailed) & $1.3989 E-8$ \\
\hline
\end{tabular}

a. Grouping Variable: Location

Appendix 4.2: Boulevard Trees vs Park Trees

Table A4.2: Mann-Whitney U test between trees on boulevards and in parks.

\section{Ranks}

\begin{tabular}{lr|r|r} 
Location & N & Mean Rank & \multicolumn{1}{c}{$\begin{array}{l}\text { Sum of } \\
\text { Ranks }\end{array}$} \\
\hline Boulevard & 42 & 42.65 & 1791.50 \\
\hline Park & 57 & 55.41 & 3158.50 \\
\hline Total & 99 & & \\
\hline
\end{tabular}




\section{Test Statistics ${ }^{\mathrm{a}}$}

\begin{tabular}{lr} 
& \multicolumn{1}{c}{ Rating } \\
\hline Mann-Whitney U & 888.500 \\
\hline Wilcoxon W & 1791.500 \\
\hline$Z$ & -2.267 \\
\hline Asymp. Sig. (2-tailed) & .023 \\
\hline
\end{tabular}

a. Grouping Variable: Location

Appendix 4.3: Boulevard Trees vs West Toronto Railpath Trees

Table A4.3: Mann-Whitney U test between boulevards and the West Toronto Railpath.

\begin{tabular}{l|r|r|r}
\multicolumn{1}{c}{ Ranks } & \\
Location & $N$ & Mean Rank & \multicolumn{1}{c}{$\begin{array}{c}\text { Sum of } \\
\text { Ranks }\end{array}$} \\
\hline West Toronto Railpath & 265 & 148.38 & 39322.00 \\
\hline Boulevard & 52 & 213.10 & 11081.00 \\
\hline Total & 317 & & \\
\hline
\end{tabular}

\section{Test Statistics $^{\mathrm{a}}$}

\begin{tabular}{lr} 
& \multicolumn{1}{c}{ Rating } \\
\hline Mann-Whitney U & 4077.000 \\
\hline Wilcoxon W & 39322.000 \\
\hline Z & -5.017 \\
\hline Asymp. Sig. (2-tailed) & $5.2457 E-7$ \\
\hline
\end{tabular}

a. Grouping Variable: Location 


\section{Appendix 4.4: Park Trees vs West Toronto Railpath Trees}

Table A4.4: Mann-Whitney U test between parks and the West Toronto Railpath.

\begin{tabular}{l|r|r|r}
\multicolumn{2}{c}{ Ranks } & & \multicolumn{1}{c}{$\begin{array}{c}\text { Sum of } \\
\text { Ranks }\end{array}$} \\
\hline Location & $N$ & Mean Rank & \multicolumn{1}{c}{14351.00} \\
\hline Park & 57 & 251.77 & 37652.00 \\
\hline West Toronto Railpath & 265 & 142.08 & \\
\hline Total & 322 & & \\
\hline
\end{tabular}

\section{Test Statistics $^{\mathrm{a}}$}

\begin{tabular}{lr} 
& \multicolumn{1}{c}{ Rating } \\
\hline Mann-Whitney U & 2407.000 \\
\hline Wilcoxon W & 37652.000 \\
\hline Z & -8.576 \\
\hline Asymp. Sig. (2-tailed) & $9.8404 \mathrm{E}-18$ \\
\hline
\end{tabular}

a. Grouping Variable: Location

Appendix 4.5: Boulevard Trees Near Construction vs Not Near Construction

Table A4.5: Mann-Whitney U test between boulevard trees located near and not near construction.

\begin{tabular}{l|r|r|r}
\multicolumn{2}{c}{ Ranks } & & \\
Location & $N$ & Mean Rank & $\begin{array}{c}\text { Sum of } \\
\text { Ranks }\end{array}$ \\
\hline Near Construction & 16 & 35.41 & 566.50 \\
\hline Not Near Construction & 36 & 22.54 & 811.50 \\
\hline Total & 52 & & \\
\hline
\end{tabular}




\section{Test Statistics ${ }^{\mathrm{a}}$}

\begin{tabular}{lr} 
& \multicolumn{1}{c}{ Rating } \\
\hline Mann-Whitney U & 145.500 \\
\hline Wilcoxon W & 811.500 \\
\hline Z & -2.913 \\
\hline Asymp. Sig. (2-tailed) & .004 \\
\hline
\end{tabular}

a. Grouping Variable: Location

\section{Appendix 4.6: Old Railpath Trees vs New Railpath Trees}

Table A4.6: Mann-Whitney U test between old and new Railpath trees.

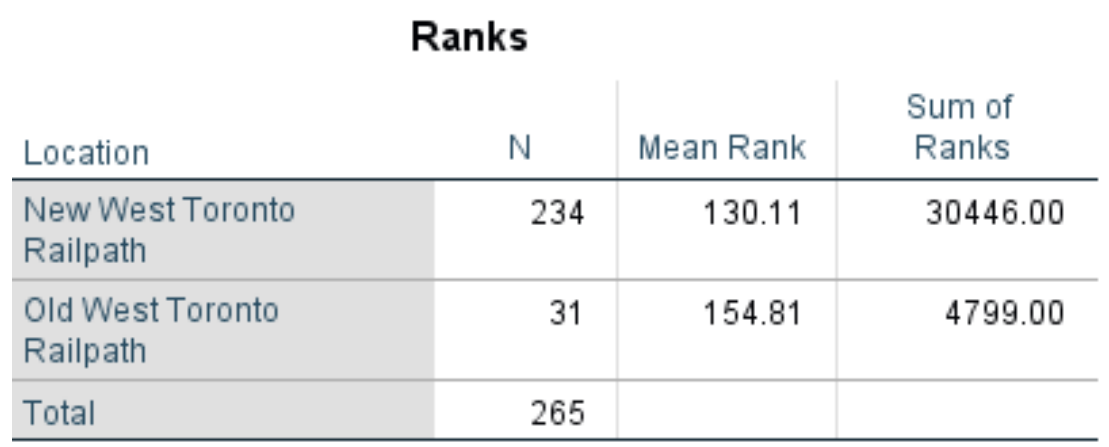

\section{Test Statistics $^{a}$}

\begin{tabular}{lr} 
& \multicolumn{1}{c}{ Rating } \\
\hline Mann-Whitney U & 2951.000 \\
\hline Wilcoxon W & 30446.000 \\
\hline Z & -1.858 \\
\hline Asymp. Sig. (2-tailed) & .063 \\
\hline
\end{tabular}

a. Grouping Variable: Location 


\section{Appendix 4.7: Trees in front of Improved vs Unimproved Homes}

Table A4.7: Mann-Whitney U test between trees in front of improved and unimproved homes.

\begin{tabular}{|c|c|c|c|}
\hline \multirow[b]{2}{*}{ Location } & \multicolumn{3}{|c|}{ Ranks } \\
\hline & $N$ & Mean Rank & $\begin{array}{l}\text { Sum of } \\
\text { Ranks }\end{array}$ \\
\hline Improved Homes & 313 & 174.95 & 54760.00 \\
\hline Unimproved Homes & 56 & 241.16 & 13505.00 \\
\hline Total & 369 & & \\
\hline
\end{tabular}

\section{Test Statistics ${ }^{\mathrm{a}}$}

\begin{tabular}{lr} 
& \multicolumn{1}{c}{ Rating } \\
\hline Mann-Whitney U & 5619.000 \\
\hline Wilcoxon W & 54760.000 \\
\hline Z & -4.816 \\
\hline Asymp. Sig. (2-tailed) & 0.000001 \\
\hline
\end{tabular}

a. Grouping Variable: Location 


\section{References}

Albers, J., Bedker, P., MacKenzie, M., O’Brien, J., \& Pokorny, J. (2012) How to recognize hazardous defects in trees. Retrieved from: http://www.newtowntownship.org/wp-content /uploads/2015/11/ How-To-Recognize-Hazardous-Defects-in-Trees.pdf

Anderson, L.M., \& Cordell, H.K. (1988) Influence of trees on residential property values in Athens, Georgia: A survey based on actual sales prices, Landscape and Urban Planning. $15,153-164$.

Angwin, P.A., Cluck, D.R., Zambino, P.J., Oblinger, B.W., \& Woodruff, W.C. (2012) Hazard tree guidelines for forest service facilities and roads in the Pacific Southwest Region. Retrieved from: https://www.fs.usda.gov/Internet/FSE_DOCUMENTS/stelprdb 5332560.pdf

Balram, S., \& Dragicevic, S. (2005) Attitudes toward urban green spaces: integrating questionnaire survey and collaborative GIS techniques to improve attitude measurements, Landscape \& Urban Planning. 71, $147-162$.

Baum, A. E. (1993) Quality, depreciation and property performance, Journal of Real Estate Research. 8(4), $541-565$.

Beauregard, R.A. (1986). The chaos and complexity of gentrification: in Smith, N. \& Williams, P., Gentrification of the city. London, United Kingdom: Unwin Hyman.

Bernhardt, E.A., \& Swiecki, T.J., (2001) Guidelines for developing and evaluating tree ordinances. Retrieved from: http://www.isa-arbor.com/education/resources/educ_ treeordinanceguidelines.pdf 
Caulfield, J. (1994) City Form and everyday life: Toronto's gentrification and critical social practice. Toronto, Canada: University of Toronto Press.

Chacalo, A., Aldama, A., \& Grabinsky, J. (1994) Street tree inventory in Mexico City, Journal of Arboriculture. 20(4), $222-226$.

Chiesure, A. (2004) The role of urban parks for the sustainable city, Landscape and Urban Planning. 68, $129-138$.

City of Toronto (2003) New official plan-avenue studies; official plan and zoning by-law amendments to implement the Bloor/Lansdowne area avenue study (Ward 14 - ParkdaleHigh Park; and Ward 18 - Davenport). Retrieved from the City of Toronto website: http://www.toronto.ca/legdocs/2003/agendas/council/cc030414/yk3rpt/c1005.pdf

City of Toronto (2013). Beside the tracks: Knitting the rail corridor back to the community ward 18. Retrieved from the City of Toronto website: http://www.toronto.ca/legdocs/mmis/2013/te/bgrd/backgroundfile-63439.pdf

City of Toronto (no date). Every tree counts: Help grow Toronto's street tree canopy. Retrieved from: https://www.toronto.ca/data/parks/pdf/trees/street-tree-brochure.pdf

Clay, P. (1979) Neighbourhood renewal: Middle-class resettlement and incumbent upgrading in American neighbourhoods. Lexington, Massachusetts: Lexington Books

Cowett, F.D., \& Bassuk, N.L. (2014) Statewide assessment of street trees in New York State, USA, Urban Forestry \& Urban Greening. 13, 213 - 220.

Creswell, J.W. (2003) Research design: Qualitative, quantitative and mixed methods approaches $2^{\text {nd }}$ edition. Thousand Oaks, California: Sage Publications. 
Cullen, S. (2007) Putting a value on trees: CTLA guidance and methods, Arboricultural Journal, $30,21-43$.

Cumming, A.B., Twardus, D.B., \& Nowak, D.J. (2008) Urban forest health monitoring: Largescale assessments in the United States, Arboriculture \& Urban Forestry. 34(6), 341 346.

Ding, J., Wu, Y., Zheng, H., Fu, W., Reardon, R., \& Liu, M. (2006) Assessing potential biological control of the invasive plant, tree of heaven, Ailthanus altissima, Journal of Biocontrol Science and Techonology. 16(5), $547-566$.

Dwyer, J.F., McPherson, E.G., Schroeder H.W., \& Rowntree, R.A. (1992) Assessing the benefits and costs of the urban forest, Journal of Arboriculture. 18(5), 227 - 234.

Dwyer, J.F., Nowak, D.J., \& Watson, G.W. (2002) Future directions for urban forestry research in the United States, Journal of Arboriculture. 28(5), 231 - 236.

Endress, A.G. (1990) The importance of diversity in selecting trees for urban areas, Journal of Arboriculture. 16(6), 143 - 147.

Escobedo, F.J., Adams, D.C., \& Timilsina, N. (2014) Urban forest structure effects on property value, Ecosystem Services. 12, 209 - 217.

Firehock, K. (2015) Strategic green infrastructure planning: A multi scale approach. Washington D.C.: Island Press.

Glaeser, E.L. \& Gyourko, J. (2005). Urban decline and durable housing, Journal of Political Ecology. 113(2), $345-375$. 
Google Earth V 7.1.7.2606. (November 17, 2007) Junction Triangle, Toronto, Ontario, Canada. 43.660710, -79.452309, Eye alt 431 m. DigitalGlobe 2016 [November 11, 2015].

Google Earth V 7.1.7.2606. (April, 19, 2012) Junction Triangle, Toronto, Ontario, Canada. 43.660710, -79.452309, Eye alt 431 m. DigitalGlobe 2016 [November 11, 2015].

Google Maps. (2016a) The Junction Triangle. Retrieved from: https://www.google.ca/maps/place/Junction+Triangle,+Toronto,+ON/@43.6588792,79.459836,15z/data=!3m1!4b1!4m5!3m4!1s0x882b3438ef17e0f1:0xd40c7d89513dd4c6! $8 \mathrm{~m} 2 ! 3 \mathrm{~d} 43.6613564 ! 4 \mathrm{~d}-79.4492924 ? \mathrm{hl}=\mathrm{en}$

Google Maps. (2016b) The City of Toronto and the Junction Triangle. Retrieved from: https://www.google.ca/maps/place/Junction+Triangle,+Toronto,+ON/@43.6661375,79.3991705,12.43z/data=!4m5!3m4!1s0x 882b3438ef17e0f1:0xd40c7d89513dd4c6!8m2! 3d43.6613564!4d-79.4492924?hl=en

Government of Ontario (no date) The Tree Atlas. Retrieved from: https://www.ontario.ca/environment-and-energy/tree-atlas

Green Here (no date) Tree inventory: The value of green infrastructure. Retrieved from: http://www.greenhere.ca/tree-inventory.html

Gregory, D., Johnston, R., Pratt, G., Watts, M.J., \& Whatmore, S. (2009) The dictionary of human geography, $5^{\text {th }}$ edition. Pondicherry, India: Blackwell Publishing.

Hackworth, J., and N. Smith (2001) The changing state of gentrification, Tijdscllrijt voor economische en sociale geografie. 22: 464-477. 
Helms, A.C. (2003) Understanding gentrification: an empirical analysis of the determinants of urban housing renovation, Journal of Urban Economics. 54(3), $474-498$

Heynen, N. (2006) Green urban political ecologies: Toward a better understanding of inner-city environmental change, Environment and Planning. 38, 499 - 516.

Johnston, M. (2015) Trees in towns and cities: A history of British urban arboriculture. Oxford, United Kingdom: Oxbow Books.

Junction Triangle (no date) Industry. Retrieved from: http://www.junctiontriangle.ca/taxonomy/term/15

Kaplan, D., Wheeler J., \& Holloway, S. (2009) Urban geography. Hoboken, New Jersey: John Wiley \& Sons.

Kenney, A. (2006) Neighbourwoods: A volunteer-based approach to assessing the condition of urban forests, Canadian Trees. Retrieved from: http://neighbourwoods.org/uploads/3/4/5/5/3455999/neighbourwoodscanadiantreeskenne y2006.pdf

Kern, L. (2014) From toxic wreck to crunchy chic: Environmental gentrification through the body, Environmental and Planning D: Society and Space. 33, $67-83$

Konijnendijk, C.C., Ricard, R.M., Kenney, A., \& Randrup, T.B. (2006) Defining urban forestry: A comparative perspective of North America and Europe, Urban Forestry and Urban Greening. 4, $93-103$.

Laverne, R.J., \& Lewis, G.M. (1996) The effect of vegetation on residential energy use in Ann Arbor, Michigan, Journal of Arboriculture. 22(5), 234 - 243. 
Lees, L., Slater, T., \& Wyly, E.K. (2008) Gentrification. Abingdon, United Kingdom: Taylor \& Francis.

Ley, D. (1986) Alternative explanations for inner-city gentrification: A Canadian assessment, Annals of the Association for American Geographers. 76(4)., 521 - 535.

Lohr, V., Pearson-Mims, C.H., Tarnai, J., \& Dillman, D.A. (2004) How urban residents rate and rank the benefits and problems associated with trees in cities, Journal of Arboriculture. $30(1), 28-35$.

Madi, H., Birchall, D., DeSorcy, L., Eichfus-Clarke, M., Floro, E., Gottwald, V., ... Wong, D. (2015) Townhouse and low-rise apartment guidelines. Retrieved from: https://www.toronto.ca/legdocs/mmis/2015/pg/bgrd/backgroundfile-85546.pdf

Manes, F., Salvatori, E., La Torre, G., Villari, P., Vitale, M., Biscontini, D., \& Incerti, G. (2008) Urban green and its relation with air pollution: Ecological studies in the metropolitan area of Rome, Italian Journal of Public Health. 5, 278 - 283.

Mann, H.B., \& Whitney, D.R. (1947) On a test of whether one of two random variables is stochiastically larger than the other, The Annals of Mathematical Statistics, 18(1), 50 60.

McPherson, E.G., Nowak, D.J., Heisler, G., Grimmond, S., Souch, C. Grant, R., \& Rowntree, R. (1991) Quantifying urban forest structure, function, and value: The Chicago urban forest climate project, Urban Ecosystems. 1, 49-61.

McComb, B.C. (2015) Wildlife habitat management: Concepts and applications in forestry, second edition. Boca Raton, Florida: Taylor Francis Group. 
Merse, C.L., Buckley, G.L., \& Boone, C.G. (2008) Street trees and urban renewal: A Baltimore case study, The Geographical Bulletin. 50, $65-81$.

Metrolinx (2015) Dundas west-bloor mobility hub profile. Retrieved from: http://www.metrolinx.com/mobilityhubs/en/map/mobility_hubs_map/MHP_DundasWest -Bloor.pdf

Miller, R.H., and Sylvester, W.A. (1981) An economic evaluation of the pruning cycle, Journal of Arboriculture. 7, 185 - 191.

Miller, R.W., Hauer, R.J., \& Wener, L.P. (2015) Urban forestry: Planning and managing urban greenspaces third edition. Long Grove, Illinois: Waveland Press.

Neighbourwoods (no date) Neighbourwoods neighbourhoods. Retrieved from: http://neighbourwoods.org/neighbourwoods-neighbourhoods.html

Nowak, D.J., \& Rowntree, R.A. (1990) History and range of Norway maple, Journal of Arboriculture. 16(11), $291-296$.

Nowak, D.J., Rowntree, R.A., McPherson, E.G., Sisinni, S.M., Kerkmann, E.R., \& Stevens, J.C. (1996) Measuring and analyzing urban tree cover, Landscape and Urban Planning. 36, $49-57$.

Nowak, D.J., Crane, D.E., \& Stevens, J.C., (2006) Air pollution removal by urban trees and shrubs in the United States, Urban Forestry and Urban Greening. 4, 115 - 123.

Nowak, D.J., Stein, S.M., Randler, P.B., Greenfield, E.J., Comas, S.J., Carr, M.A., ... Alig, R.J. (2010) Sustaining America's urban trees and forests: A forests on edge report. Retrieved from: http://www.fs.fed.us/openspace/fote/reports/nrs-62_sustaining_americas_urban.pdf 
Nowak, D.J., Hoehn, R.E., Bodine, A.R., Greenfield, E.J, Ellis, A., Endreny, T.A....Henry, R. (2013) Assessing urban forest effects and values: Toronto's urban forest, United States Department of Agriculture Forest Service Northern Research Station Resource Bulletin $N R S$ - 79. Retrieved from: https://www1.toronto.ca/City\%20Of\%20Toronto/Parks\%20Forestry\%20\&\%20Recreatio n/Urban\%20Forestry/Files/pdf/R/Reports/effects-and-values.pdf

Nulty, D.D. (2008) The adequacy of response rates to online and paper surveys: What can be done?, Assessment \& Evaluation in Higher Education. 33(3), 301 - 314.

Pandit, R., \& Laband, D.N. (2010) A hedonic analysis of the impact of tree shade on summertime residential energy consumption, Arboriculture and Urban Forestry. 26(2), $73-80$.

Perry, J., \& Vanderklein, E. (1996) Water quality: Management of a natural resource. Cambridge, Massachusetts: Wiley-Blackwell.

Saracino, J.B. (2010) The gentrification debates. New York, New York: Routledge.

Schroeder, H.W. (1989) Esthetic perceptions of the urban forest: A utility perspective, Journal of Arboriculture. 15(12), $292-294$.

Sibley, D.A. (2009) The Sibley guide to trees. New York, New York: Alfred A. Knopf.

Simpson, J.R., \& McPherson, E.G (1996) Potential of tree shade for reducing residential energy use in California, Journal of Arboriculture. 22(1), 10 - 18.

Sjöman, H., Östberg, J., \& Bühler, O. (2011) Diversity and distribution of the urban population in ten major Nordic cities, Urban Forestry \& Urban Greening. 11, 31 - 39. 
Slater, T. (2010) Gentrification of the city: in Bridge, G. \& Watson, S., The new blackwell companion to the city. Oxford, United Kingdom: Blackwell Publishing

Smith, N. (1987) Gentrification and the rent gap, Annals of the Association of American Geographers. 77(3), $462-465$.

Smith, N. (1996) The new urban frontier: Gentrification and the revanchist city. London, United Kingdom: Routledge.

Sreetheran M., Adnan, M., \& Khairil Azuar, A.K. (2011) Street tree inventory and tree risk assessment of selected major roads in Kuala Lumpur, Malaysia, Arboriculture \& Urban Forestry. 37(5), $226-235$

Steenberg, J.W.N., Robinson. P.J., \& Millward, A.A. (2017) The influence of building renovation and rental housing on urban trees, Journal of Environmental Planning and Management. 61(3), 553 - 567.

Statistics Canada (no date) Classification of residential structures. Retrieved from: http://www23.statcan.gc.ca/imdb/p3VD.pl?Function=getVD\&TVD=144257\&CVD=144 $258 \& \mathrm{CLV}=0 \& \mathrm{MLV}=2 \& \mathrm{D}=1$

Statistics Canada (2001) Ward 18: Ward profiles City of Toronto. Retrieved from: http://www1.toronto.ca/city_of_toronto/city_planning/wards/files/pdf/wardprofiles_18.pdf

Statistics Canada (2006) City of Toronto ward profiles: Ward 18. Retrieved from: http://www1.toronto.ca/city_of_toronto/city_planning/wards/files/pdf/ward18_2006profil es.pdf 
Statistics Canada (2011a) City of Toronto ward profiles: 2011 census ward 18 - Davenport. Retrieved from: http://www1.toronto.ca/City\%20Of\%20Toronto/City\%20Planning/Wards/Files/pdf/W/W ard\%2018\%20Profile\%202011.pdf

Statistics Canada (2011b) City of Toronto ward profiles: 2011 national household survey ward 18 - Davenport. Retrieved from: https://www1.toronto.ca/City\%20Of\%20Toronto/City\%20Planning/Wards/Files/pdf/W/ Ward\%2018\%20NHS\%20Profile\%202011.pdf

Stolte, K., Conkling, B., Campbell, S., \& Gillespie, A. (2002) Forest health indicators: Forest inventory and analysis program. Retrieved from: http://www.fia.fs.fed.us/library/brochures/docs/Forest_Health_Indicators.pdf

Sun, W.Q. (1992) Quantifying species diversity of streetside trees in our cities, Journal of Aboriculture. 18(2), 91 - 93.

Thompson, I., Mackey, B., McNulty, S., \& Mosseler, A. (2009) Forest resilience, biodiversity, and climate change: A synthesis of the biodiversity/resilience/stability relationship in forest ecosystems, Secretariat of the Convention on Biological Diversity. Retrieved from: https://www.cbd.int/doc/publications/cbd-ts-43-en.pdf

Tyrväinen, L., Pauleit, S., Seeland, K., \& de Vries, S. (2005) Benefits and uses of urban forests and trees: in Konijnendijk, C.C., Nilsson, K., Randrup, T.B., \& Schipperijn, J., Urban forests and trees: A reference book. Netherlands: Springer. 
Watt, S., Simpson, C., McKillop, C., \& Nunn, V. (2002) Electronic course surveys: does automating feedback and reporting give better results? Assessment \& Evaluation in Higher Education. 27(4), 325 - 337.

Warne, A. (2016) Black locust, Robinia pseudoacacia L., best management practices in Ontario. Retrieved from: http://www.ontarioinvasiveplants.ca/wpcontent/uploads/2016/06/Black_Locust_BMP.pdf

Whaley, B.B. (2014) Research methods in health and communication: Principles and application. New York City, New York: Routledge.

Wilson, C., Chrysochoidis, G., \& Pettifor, H. (2013) Understanding homeowners' renovation decisions: Findings of the VERD project. Retrieved from: https://ueaeprints.uea.ac.uk/47107/1/VERD_Summary_Report_1Oct13.pdf

Wolch, J.R., Byrne, J., \& Newell, J.P. (2014) Urban green space, public health, and environmental justice: the challenge of making cities 'just green enough', Landscape and Urban Planning. 125, $234-244$.

Wyly, E.K., \& Hammel, D.J. (1999) Islands of decay in seas of renewal: Housing policy and the resurgence of gentrification, Housing Policy Debate. 10(4), 711 - 771. 